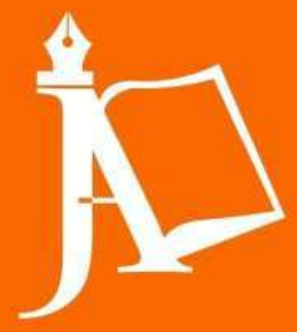

JURNAL

Vol 1, No 2, Desember 2020 p-issn : 2723-3839

ALPHAEUCLIDEDU

Jurnal Matematika dan Pendidikan Matematika FKIP UNTAN

http://jurnal.untan.ac.id/index.php/AlphaEuclidEdu

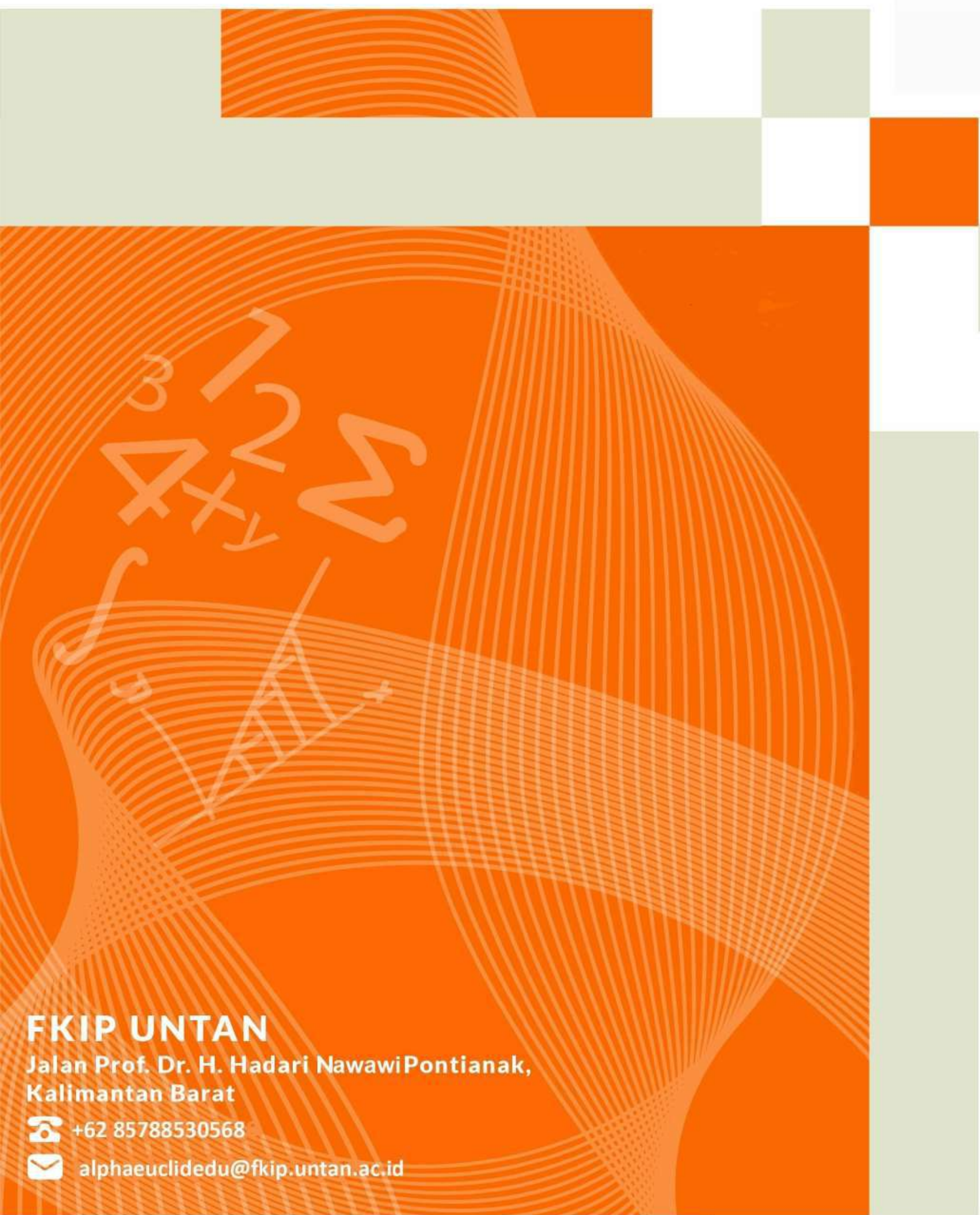


JURNAL ALPHAEUCLIDEDU

JURNAL KEILMUAN MATEMATIKA DAN PENDIDIKAN MATEMATIKA

SURAT KEPUTUSAN DEKAN FKIP UNIVERSITAS TANJUNGPURA

NOMOR : 13186/UN22.6/D1.04/2019 TANGGAL 12 SEPTEMBER 2019

\author{
Pelindung: \\ Dekan FKIP Universitas Tanjungpura \\ Penanggung Jawab: \\ Unit Penelitian Pengembangan Penerbitan dan Publikasi Ilmiah (UP4I) FKIP \\ Untan \\ Pemimpin Redaksi (Editorial In Chief) \\ Dr. Dede Suratman, M.Si \\ Sekretaris Redaksi (Managing Editorial) \\ Dona Fitriawan, M.Pd \\ Editor (Section Editorial) \\ 1. Prof. Dr. Nanang Priatna, M.Pd (Universitas Pendidikan Indonesia) \\ 2. Drs. Asep Nursangaji, M.Pd (Universitas Tanjungpura) \\ 3. Dr. Sugiatno, M.Pd (Universitas Tanjungpura) \\ 4. Dr. Mohamad Ri'fat, M.Pd (Universitas Tanjungpura) \\ 5. Dr. Hamdani, M.Pd (Universitas Tanjungpura)
}

Penyunting Ahli (Reviewers)

1. Prof. Dr. Toto Nusantara, M.Si (Universitas Negeri Malang)

2. Prof. Dr. Suradi, M.S (Universitas Negeri Makassar)

3. Prof. Dr. Edy Sahputra, M.Pd (Universitas Negeri Medan)

4. Dr. Heris Hendriana, M.Pd (IKIP Siliwangi)

5. Dr. Yulis Jamiah, M.Pd (Universitas Tanjungpura)

6. Dr. Agung Hartoyo, M.Pd (Universitas Tanjungpura)

7. Drs. Edy Yusmin, M.Pd (Universitas Tanjungpura)

8. Drs. Ade Mirza, M.Pd (Universitas Tanjungpura)

9. Dr. Bistari, M.Pd

10. Drs. Dian Ahmad, M.Pd

11. Drs. Romal Ijuddin, M.Pd

(Universitas Tanjungpura)

(Universitas Tanjungpura)

(Universitas Tanjungpura) 


\section{PENGANTAR}

Puji syukur Kami haturkan kehadirat Tuhan Yang Maha Esa, atas terbitnya Jurnal Pendidikan Matematika yang bernama Jurnal AlphaEuclidEdu pada edisi Juli 2020. Jurnal AlphaEuclidEdu mencakup bidang matematika dan pendidikan matematika dengan rincian: 1) Belajar dan Pembelajaran Matematika ; 2) Media dan Sumber Belajar Matematika; 3) Kurikulum Matematika; 4) Evaluasi Pembelajaran Matematika; 5) Profesi Pendidik Matematika; 6) Matematika Untuk Ekonomi; 7) Statistika; 8) Geometri; 9) Aljabar; 10) Analisis; 11) Kalkulus; 12) Trigonometri.

Jurnal AlphaEuclidEdu diterbitkan oleh Program Studi Pendidikan Matematika yang diprakasai oleh UP4I (Unit Penelitian Pengembangan Penerbitan dan Publikasi Ilmiah) FKIP Universitas Tanjungpura. Tentunya juga jurnal ini diterbitkan atas partisipasi semua pihak yang turut berkonstribusi, khususnya para penulis yang telah mempercayakan tulisannya dimuat pada jurnal ini. Terbitnya jurnal ini merupakan berkat kerja sama yang baik para Tim Editor dan Para Reviewer.

Kami percaya bahwa Tuhan Yang Maha Esa senantiasa membalas semua kebaikan

yang dilakukan semua pihak dalam atensinya sebagai amal bakti untuk memajukan kualitas pendidikan serta mengembangkan kebiasan menulis dalam nuansa ilmiah. Akhirnya, kami berharap kritik dan saran yang bermanfaat agar jurnal ini mampu memberikan konstribusi yang lebih baik di masa mendatang.

Pontianak, 8 Desember 2020

Tim Editor 


\section{DAFTAR ISI}

Volume 1, Nomor 2, Desember 2020

PENGANTAR

iii

DAFTAR ISI

iv

UPAYA MENINGKATKAN AKTIVITAS DAN HASIL BELAJAR MATEMATIKA DENGAN METODE TUTOR SEBAYA PADA MATERI MATRIKS.

Darmawati

KESALAHAN SISWA DALAM MENYELESAIKAN SOAL STATISTIKA TIPE HIGHER ORDER THINKING SKILLS...

Safrida Dwi Damayanti, Agung Hartoyo, Dede Suratman

KEMAMPUAN MENYELESAIKAN SOAL PISA PADA KONTEN CHANGE AND RELATIONSHIP.

Helyana Teresa, Zubaidah, Asep Nursangaji

PENGUATAN KARAKTER SISWA PERBATASAN MELALUI INTERNALISASI KEARIFAN LOKAL DALAM PEMBELAJARAN MATEMATIKA

Yulis Jamiah

KEMAMPUAN KOMUNIKASI MATEMATIS SISWA DIKAJI DARI SELF CONFIDENCE.

Tjut Aflianti Eka Putri, Yulis Jamiah, Silvia Sayu

EKSPLORASI KETERAMPILAN KERUANGAN MENGENAI KUBUS MELALUI WAWANCARA KLINIS BERBASIS MASALAH.

Antonius Medellu, Sugiatno, Agung Hartoyo

KEMAMPUAN KOMUNIKASI MATEMATIS SISWA DIKAJI DARI SELF CONFIDENCE.

Ade Mirza

PENGEMBANGAN INSTRUMEN EKSPLORASI KONSEP GEOMETRI BERSTRUKTUR DARI TEORI VAN HIELE BERBANTUAN SOFTWARE GEOGEBRA....

Dominicus Savio Pratikna, Sugiatno, Agung Hartoyo

TANTANGAN BELAJAR MATEMATIKA DALAM MATERI ARITMATIKA SOSIAL PADA PESERTA DIDIK BERKEBUTUHAN KHUSUS. . . 
POTENSI BERPIKIR KRITIS SISWA DALAM MENYELESAIKAN MASALAH

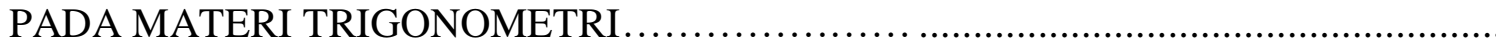

Halimatussa'diah, Sugiatno, Romal Ijuddin

TINGKAT KEPUASAN MAHASISWA TERHADAP LAYANAN AKADEMIK.....

Hamdani, Asep Nursangaji

PENGEMBANGAN BAHAN AJAR INTERAKTIF UNTUK PEROLEHAN

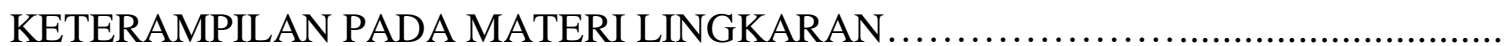
Ulvi Ulya, Dede Suratman, Asep Nursangaji

MISKONSEPSI SISWA DALAM MENYELESAIKAN SOAL HIMPUNAN

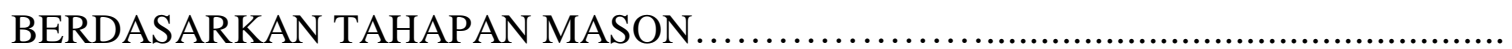
Andi Dwi Melianti, Edy Yusmin, Asep Nursangaji

TINGKAT KEPUASAN MAHASISWA TERHADAP LAYANAN BIMBINGAN TUGAS AKHIR. 
Vol 1 No 22020 Desember 2020

Jurnal AlphaEuclidEdu

Received: 01/11/2019; Revised: 24/07/2020; Accepted: 02/12/2020

\title{
UPAYA MENINGKATKAN AKTIVITAS DAN HASIL BELAJAR MATEMATIKA DENGAN METODE TUTOR SEBAYA PADA MATERI MATRIKS
}

\author{
Darmawati \\ Guru Matematika SMA Negeri 1 Sekadau \\ Email: darmatematika@gmail.com
}

\begin{abstract}
Abstact
The purpose of this study was to improve the activities and learning outcomes of students of class XI MIA 3 in SMA Negeri 1 Sekadau in the academic year 2019/2020 on matrix material using peer tutoring methods. This type of research is a classroom action research carried out in 2 cycles, each cycle consisting of 4 stages of planning, action implementation, observation and reflection. Retrieval of data through a collection using a collection of observations and learning outcomes are obtained by providing a final test at the end of each cycle. The results of observations for student activity during pre-cycle $67.81 \%$ in the first cycle to $76.88 \%$ and in the second cycle to $86.46 \%$ means that there is an increase of $17.82 \%$. Mathematical learning outcomes from the first cycle increased by $41.00 \%$, while from the first cycle to the second cycle increased by $14.46 \%$. So it can be removed by using the peer tutoring method to increase the activity and learning outcomes of students of class XI MIA 3 of SMA Negeri 1 Sekadau in the academic year 2019/2020 on matrix material.
\end{abstract}

Keywords: activities, learning outcomes of peer tutoring methods, matrix

\section{Pendahuluan}

Dalam seluruh proses pendidikan, kegiatan pembelajaran merupakan proses pokok yang harus dilalui oleh seorang guru. Berhasil tidaknya tujuan pendidikan bergantung pada bagaimana proses belajar mengajar dirancang dan disajikan. Proses pembelajaran yang baik akan menghasilkan hasil belajar yang baik dan sebaliknya, Menurut E. Mulyasa (2008: 212), "hasil belajar merupakan prestasi peserta didik secara keseluruhan yang menjadi indikator kompetensi dasar dan derajat perubahan tingkah laku yang bersangkutan". Menurut Nana Sudjana (2010: 2), "hasil belajar merupakan kemampuan-kemampuan yang dimiliki peserta didik setelah ia menerima pengalaman belajarnya". Hasil belajar pada hakekatnya merupakan kompetensi yang mencakup aspek pengetahuan, ketrampilan, sikap dan nilai-nilai yang diwujudkan dalam kebiasaan berfikir dan bertindak. Menurut S Bloom hasil belajar pengetahuan terdiri-dari empat kategori yaitu fakta, procedural, konsep, prinsip. Dengan demikian dapat disimpulkan bahwa hasil belajar merupakan kemampuan yang dimiliki peserta didik setelah melakukan proses pembelajaran dalam mencapai suatu tujuan pembelajaran.

Selain hasil belajar, aktivitas siswa juga merupakan hal yang sangat penting dan perlu diperhatikan oleh seorang guru sehingga proses belajar yang ditempuh benarbenar akan mencapai tujuan belajar. Perlunya aktivitas dalam belajar, dikarenakan belajar menurut Gagne adalah perubahan kemampuan yang dicapai seseorang melalui aktivitas (Suprijono,A, 2010). Jadi, dapat dikatakan bahwa belajar adalah melakukan aktivitas. Pembelajaran aktif secara sederhana adalah model pembelajaran yang melibatkan peserta didik secara aktif dalam proses pembelajaran. Hasil riset dari Nasional Training Laboratories di Barhel, Maine (1954), Amerika Serikat menunjukan 
Vol 1 No 22020 Desember 2020

Jurnal AlphaEuclidEdu

Received: 01/11/2019; Revised: 24/07/2020; Accepted: 02/12/2020

bahwa jika peserta didik diberi kesempatan melakukan sesuatu (doing something) mereka dapat menggigat 75\% (Warsono dan Hariyanto, 2013: 12).

Namun kenyataannya sampai saat ini pelajaran matematika masih kurang diminati oleh sebagian besar siswa, dikarenakan pembelajaran di sekolah masih berpusat pada guru (teacher centered) yang seharusnya berpusat pada siswa (student centered). Pembelajaran materi matriks di SMA masih jauh dari memuaskan. Hal ini dapat dilihat dari hasil UAN dari tahun ke tahun yang didalamnya terdapat materi matriks yang termasuk dalam kategori "rendah". Menurut Nana Sudjana (2010: 39), hasil belajar yang dicapai peserta didik dipengaruhi oleh dua faktor utama, yaitu faktor dari dalam diri peserta didik (faktor internal) dan faktor yang datang dari luar diri peserta didik (faktor eksternal). Kedua faktor tersebut saling mempengaruhi dalam proses belajar individu sehingga mempengaruhi kualitas hasil belajar. Hasil belajar merupakan kemampuan yang dimiliki peserta didik setelah melalui proses belajar yang sesuai dengan tujuan pembelajaran. Untuk mencapai hasil belajar yang maksimal dipengaruhi oleh berbagai faktor, salah satunya adalah ketepatan dalam memilih metode pembelajaran agar materi dapat diterima peserta didik dengan baik.

Salah satu metode pembelajaran yang diduga dapat meningkatkan aktivitas dan hasil belajar siswa adalah metode pembelajaran tutor sebaya (Peer tutoring). Hasil penelitian Prasojo,T (2016) menyatakan bahwa aktivitas siswa meningkat $17,54 \%$ dan hasil belajar siswa meningkat 23,12 karena menggunakan metode tutor sebaya. Menurut Suherman dalam Anggorowati (2011), sumber belajar tidak harus selalu dari guru. Sumber belajar dapat diperoleh dari teman satu kelas yang lebih pandai atau dari orang lain. Sumber belajar bukan guru dan berasal dari orang lain yang lebih pandai disebut Tutor. Ada dua macam tutor, yaitu tutor sebaya dan tutor kakak. Tutor sebaya adalah teman sebaya yang lebih pandai.

Menurut Benny. A (2011: 44), "Metode tutor sebaya dapat diartikan sebagai penyajian informasi, konsep dan prinsip yang melibatkan siswa secara aktif di dalamnya", Sehubungan dengan hal itu, Suherman dalam Anggorowati (2011) mengatakan bahwa tutor sebaya adalah sekelompok siswa yang telah tuntas terhadap materi pelajaran, memberikan bantuan kepada siswa yang mengalami kesulitan dalam memahami bahan pelajaran yang dipelajarinya, sedangkan menurut Arikunto dalam Budi Kristina (2013), tutor sebaya adalah seseorang atau beberapa siswa yang ditunjuk oleh guru sebagai pembantu guru dalam melakukan bimbingan terhadap kawan sekelas untuk melaksanakan program perbaikan.

Dari ketiga definisi di atas, dapat diambil kesimpulan bahwa inti dari metode tutor sebaya adalah pemanfaatan beberapa siswa yang pandai untuk memberikan bantuan belajar kepada teman sekelasnya yang kurang pandai. Menurut Suryo dan Amin dalam Retno Sapto Rini Sudiasih (2011), pemilihan siswa tutor ini berdasarkan beberapa kriteria, diantaranya yaitu siswa tutor harus memiliki kemampuan dalam penguasaan materi pelajaran, kemampuan membantu orang lain baik secara individu maupun kelompok, prestasi belajar yang tergolong baik, hubungan sosial yang baik dengan teman-temannya, memiliki kemampuan dalam memimpin kegiatan kelompok, disenangi 
Vol 1 No 22020 Desember 2020

Jurnal AlphaEuclidEdu

Received: 01/11/2019; Revised: 24/07/2020; Accepted: 02/12/2020

dan diterima oleh teman-temannya. Kelebihan dari metode tutor sebaya ini adalah hubungan yang dekat antara siswa yang dibantu dengan siswa yang membantu (tutor), merupakan pengayaan dan menambah motivasi belajar bagi tutor, meningkatkan rasa tanggung jawab, kepercayaan diri, dan rasa setia kawan yang tinggi.

Berdasarkan uraian di atas, maka penulis tertarik untuk melakukan penelitian tentang upaya meningkatkan aktivitas dan hasil belajar matematika dengan metode tutor sebaya pada materi matriks di kelas XI MIA 3 SMAN 1 Sekadau. Masalah dalam penelitian ini adalah: (1) Apakah aktivitas belajar matematika siswa kelas XI MIA 3 SMAN 1 Sekadau pada materi Matriks dapat ditingkatkan dengan metode Tutor Sebaya? (2) Apakah hasil belajar matematika siswa kelas XI MIA 3 SMAN 1 Sekadau pada materi Matriks dapat ditingkatkan dengan metode Tutor Sebaya?

Tujuan dari penelitian ini adalah untuk mengetahui bahwa (1) aktivitas belajar matematika siswa kelas XI MIA 3 SMA Negeri 1 Sekadau pada materi Matriks dapat ditingkatkan dengan metode Tutor Sebaya dan (2) hasil belajar matematika siswa kelas XI MIA 3 SMA Negeri 1 Sekadau dapat ditingkatkan dengan menggunakan metode Tutor Sebaya.

\section{Metode Penelitian}

Penelitian ini merupakan penelitian tindakan kelas (PTK) yang terdiri atas dua siklus. Langkah dalam tiap siklus terdiri atas 4 tahapan yang berdasarkan pada prinsip metode penelitian tindakan kelas dengan model Suharsimi A, Suhardjono, Supardi (2006: 73) yang dimulai dari perencanaan, pelaksanaan, pengamatan, dan refleksi. Perencanaan meliputi Menyusun RPP, LKS, membentuk kelompok belajar dengan cara memilih beberapa siswa yang nilainya mencapai KKM saat tes prasiklus untuk dijadikaan tutor sebaya, mempersiapkan kisi-kisi dan soal tes akhir siklus I, mempersiapkan kunci jawaban soal tes akhir siklus I, mempersiapkan lembar pengamatan aktivitas belajar siswa. Pelaksanaan meliputi membentuk kelompok belajar dan memilih tutor, membimbing semua tutor dan membagi LKS untuk dibahas berkelompok, tutor mengajarkan dan membimbing teman dalam satu kelompok mengerjakan LKS, guru melakukan observasi dengan memakai lembar observasi untuk mengetahui aktivitas siswa dalam pembelajaran, masing-masing perwakilan anggota kelompok diminta menyampaikan hasil diskusi kelompoknya, akhir pembelajaran, guru bersama siswa membuat kesimpulan, akhir siklus semua siswa diberi tes akhir. Kerangka berpikir penelitian ini dapat seperti terlihat pada gambar berikut.

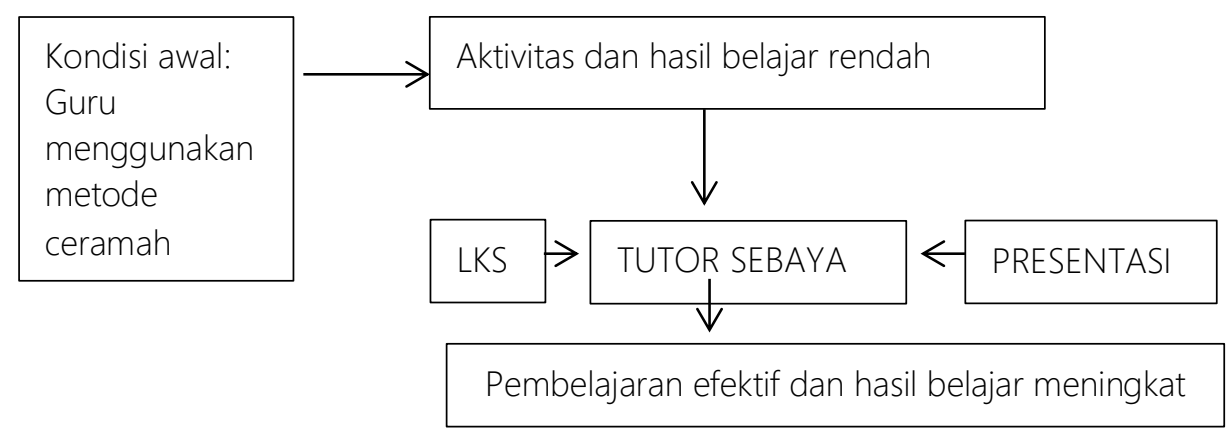


Vol 1 No 22020 Desember 2020

Jurnal AlphaEuclidEdu

Received: 01/11/2019; Revised: 24/07/2020; Accepted: 02/12/2020

\section{Gambar I. Alur Kerangka Berpikir}

Penelitian ini dilakukan di SMA Negeri 1 Sekadau dengan alasan peneliti adalah guru di sekolah tersebut dan sebagai upaya meningkatkan kompetensi pedagogik. Subyek penelitian adalah siswa kelas XI MIA 3 tahun pelajaran 2019/2020 yang berjumlah 30 siswa yang terdiri atas 10 siswa laki-laki dan 20 siswa perempuan. Alasan pemilihan kelas ini, karena aktifitas dan hasil belajar matematika di kelas ini masih rendah. Sementara pemilihan materi "matriks" dengan alasan materi matriks selalu ada dalam soal UAN, materi matriks digunakan dalam materi persamaan linear, transformasi linear. Matriks erat kaitannya materi program linear. Menggunakan representasi matriks, perhitungan dapat dilakukan dengan lebih terstruktur.

Sumber data penelitian tindakan ini meliputi siswa, guru, dokumen hasil pembelajaran, dan proses pembelajaran. Adapun teknik pengumpulan datanya dilakukan dengan cara tes tertulis berupa soal-soal yang berhubungan dengan materi matriks guna mengukur kemampuan individu yang dimiliki oleh tiap siswa setelah diberikan perlakuan pembelajaran dengan metode tutor sebaya. Tes saat pra siklus digunakan untuk mengidentifikasi pengetahuan siswa tentang matriks dan tes disetiap akhir siklus untuk mengetahui peningkatan mutu hasil belajar siswa. Pengamatan difokuskan pada tingkat partisifasi siswa dalam kelompok, seperti keaktifan bertanya, keaktifan menanggapi, keaktifan mengerjakan tugas dan sebagainya. Pengamatan dilakukan pada tiap siklus dengan mengunakan instrumen pengamatan. Metode ini dilakukan untuk memperoleh data tentang aktivitas siswa.

Analisa data dalam penelitian ini menggunakan dua teknik analisa. Data kualitatif diolah melalui analisa deskriptif komparatif yaitu membandingkan nilai tes para siklus, nilai tes setelah siklus I, dan nilai tes setelah siklus II. Sedangkan data kualitatif hasil pengamatan diolah menggunakan analisa deskriftif kualitatif berdasarkan hasil refleksi ditiap siklus.

Indikator kinerja yang digunakan adalah berdasarkan nilai KKM Matematika materi matriks di SMA Negeri 1 Sekadau tahun pelajaran 2019/2020, yaitu sebesar 70 . Tercapainya tujuan pertama yaitu adanya peningkatan keaktifan belajar siswa kelas XI MIA 3 SMA Negeri 1 Sekadau pada materi matriks sebanyak $\geq 85 \%$ siswa skor aktivitas termasuk dalam kategori baik dan Amat baik. Tercapainya tujuan kedua yaitu ada peningkatan hasil belajar matematika siswa kelas XI MIA 3 SMA Negeri 1 Sekadau pada materi matriks yang ditandai dengan rata-rata hasil belajar $\geq 70$ dengan ketuntasan keseluruhan $\geq 80 \%$ pada siklus II.

\section{Hasil dan Pembahasan}

\section{Deskripsi kondisi prasiklus}

Dari ombel kelas XI parallel yang ada di SMAN 1 Sekadau tahun pelajaran 2019/2020, terdapat 3 rombel jurusan MIA (Matematika dan Ilmu Alam) dan 4 rombel jurusan IIS (Ilmu-ilmu Sosial). Kelas XI MIA-3 berjumlah 30 siswa yang terdiri-dari 10 siswa putra dan 20 siswa putri yang aktivitas belajarnya masih kurang dan hasil belajar tergolong rendah. Hal ini dapat dilihat dari aktivitas siswa saat mengikuti kegiatan pembelajaran 
Vol 1 No 22020 Desember 2020

Jurnal AlphaEuclidEdu

Received: 01/11/2019; Revised: 24/07/2020; Accepted: 02/12/2020

dikelas saat belajar materi matriks. Dari 30 siswa di kelas XI MIA-3 hanya ada 3 siswa atau $10 \%$ termasuk kategori sangat aktif, 7 siswa atau 23,33\% termasuk kategori cukup aktif dan 20 siswa atau 66,67\% siswa tergolong pasif. Kurangnya aktifitas siswa saat belajar disebabkan oleh metode yang digunakan guru kurang melibatkan siswa.

Hasil belajar matematika siswa kelas XI MIA-3 pada saat prasiklus pada materi matriks tergolong rendah. Hal ini dapat dilihat dari rata-rata nilai ulangan harian yang masih berada di bawah KKM yang ditetapkan yaitu 70. Nilai ulangan harian pada saat prasiklus dapat dilihat pada tabel 1 berikut.

Tabel I

Data nilai ulangan pada saat prasiklus

\begin{tabular}{lc}
\hline \multicolumn{1}{c}{ Uraian } & Kondisi Prasiklus \\
\hline Nilai & 22 \\
Terendah & \\
Nilai & 90 \\
Tertinggi & \\
Rata - rata & 44,80 \\
Ketuntasan & $23,34 \%$ \\
\hline
\end{tabular}

\section{Deskripsi Hasil Penelitian Setelah Pelaksanaan Tindakan}

Siklus I

\section{Perencanaan}

Mempersiapkan perangkat pembelajaran yang digunakan berupa silabus, rencana pelaksanaan pembelajaran (RPP), lembar kerja siswa, mempersiapkan kisi-kisi soal, membuat soal dan rubrik pensekoran. RPP yang disiapkan pada siklus I digunakan untuk 3 kali pertemuan. Pertemuan 1 membahas tentang operasi matriks, pertemuan 2 membahas tentang determinan matriks, pertemuan 3 membahas tentang invers matriks dan tes evaluasi siklus I. selanjutnya peneliti mempersiapkan kisi-kisi pengamatan aktivitas, indikator dan pedoman pensekoran aktivitas berupa tabel yang akan digunakan untuk mengamati. Persiapan proses pembelajaran, peneliti memilih tutor yaitu siswa dengan lebih dibandingkan dengan siswa yang lain, dengan cara melihat hasil ulangan saat prasiklus serta kemampuan sehari-hari dalam pembelajaran matematika.

pelaksanaan

Guru menyapa siswa dengan mengucap salam, berdoa dan menyanyikan lagi nasional. Menanyakan kabar siswa dan menyiapkan psikis dan fisik siswa untuk menerima pembelajaran, kemudian menyampaikan tujuan pembelajaran.

Kegiatan Inti pembelajaran, siswa dibagi menjadi 7 kelompok, masing-masing kelompok terdiri dari 4-5 siswa. Kemudian peneliti membagikan lembar kerja siswa yang telah disediakan, setiap siswa mendapat satu lembar. Kemudian guru menjelaskan materi sesuai rencana pembelajaran yang sudah disiapkan. Pada tiap kelompok terdapat seorang tutor sebaya yang bertugas memandu jalannya diskusi dalam mengerjakan LKS. Sebelum mengisi LKS tutor sebaya beserta teman dalam kelompoknya berdiskusi 
Vol 1 No 22020 Desember 2020

Jurnal AlphaEuclidEdu

Received: 01/11/2019; Revised: 24/07/2020; Accepted: 02/12/2020

untuk mengisi LKS. Guru berkeliling untuk mengamati aktivitas siswa. Setelah diskusi selesai beberapa perwakilan kelompok mempresentasikan hasil diskusi kelompoknya.

Akhir pembelajaran dengan bimbingan guru, siswa membuat kesimpulan dari apa yang dipelajari yaitu operasi matriks. Guru memberikan informasi bahwa pada pertemuan selanjutnya akan membahas tentang determinan matriks. Guru mengucapkan salam penutup dan meminta siswa belajar dirumah melalui sumber lain. Tidak lupa guru mengucapkan terima kasih kepada semua tutor karena telah bersedia membimbing teman-temannya. Guru memberikan LKS untuk bahan belajar dirumah. Pada pertemuan kedua dan ketiga kegiatan pembelajaran hampir sama hanya berbeda pada materi pokok yang diajarkan. Setelah pemberian tindakan pada proses pembelajaran selesai, siswa diberi tes evaluasi hasil belajar berupa soal uraian sebanyak 5 soal yang sudah dipersiapkan.

Observasi

Berdasarkan hasil pengamatan aktivitas belajar siswa pada siklus I, untuk pertemuan pertama rata-rata keaktifan siswa yang termasuk katergori baik dan sangat baik adalah 2,6 atau sekitar 65\% dengan kategori cukup, Pada pertemuan kedua 2,83 atau 70,73\% dengan kategori cukup dan dan pada pertemuan ketiga 3,08 atau 76,88\% dengan kategori baik. Data aktivitas siswa dapat dilihat pada tabel II.

Tabel II

Aktivitas belajar siklus 1

\begin{tabular}{llc}
\hline $\begin{array}{l}\text { Rentang } \\
\text { Persen }\end{array}$ & Kategori & $\begin{array}{l}\text { Jumlah } \\
\text { siswa }\end{array}$ \\
\hline $86 \%-100 \%$ & Amat Baik & 2 \\
$71 \%-85 \%$ & Baik & 10 \\
$56 \%-70 \%$ & Cukup & 11 \\
$41 \%-55 \%$ & Kurang & 5 \\
$<40 \%$ & Sangat. K & 2 \\
\hline
\end{tabular}

Table II, menunjukkan bahwa aktivitas siswa dengan kategori baik dan amat baik hanya 12 siswa atau (40\%) dari 30 siswa. Aktivitas belajar siswa pada aspek memperhatikan penjelasan guru sudah tinggi. Skor keaktifan siswa dalam bekerjasama dalam diskusi sudah cukup tinggi. Hanya saja masih ada siswa yang kurang serius dalam diskusinya.

Pelaksanaan pembelajaran dengan metode tutor sebaya pada penelitian ini sudah berjalan sesuai dengan rencana kegiatan pembelajaran. Progres hasil belajar matematika dapat dilihat pada tabel III.

Tabel III

Progres hasil belajar matematika kondisi prasiklus dan siklus I

\begin{tabular}{cccc}
\hline Uraian & Kondisi Prasiklus & Kondisi Siklus I & Peningkatan \\
\hline Nilai Terendah & 22 & 26 & 4 \\
Nilai Tertinggi & 90 & 100 & 10
\end{tabular}


Vol 1 No 22020 Desember 2020

Jurnal AlphaEuclidEdu

Received: 01/11/2019; Revised: 24/07/2020; Accepted: 02/12/2020

\begin{tabular}{cccc} 
Rata - rata & 44,80 & 64,14 & 19,33 \\
Ketuntasan & $23,34 \%$ & $63,34 \%$ & $40 \%$ \\
\hline
\end{tabular}

Berdasarkan tabel III, diperoleh informasi bahwa nilai rata-rata hasil belajar pada kondisi prasiklus belum mencapai rata-rata lebih dari 70 namum mengalami peningkatan pada saat siklus I. sehingga perlu dilaksanakan siklus II. Hal ini dapat disajikan dalam gambar berikut.

Progres hasil belajar matematika kondisi prasiklus dan siklus I

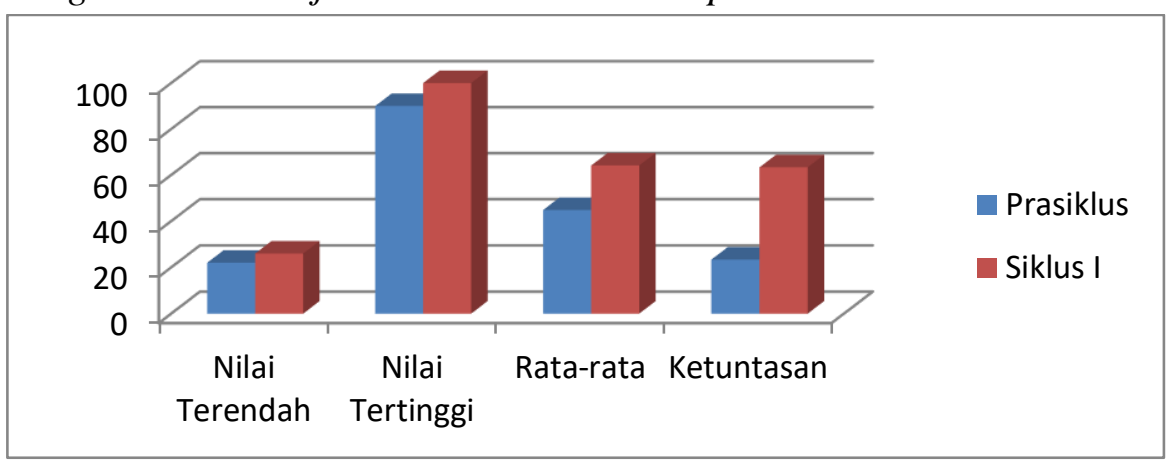

Gambar I. Data aktivitas siswa pada prasiklus dan siklus I

Refleksi

Proses pembelajaran materi matriks dengan menggunakan metode tutor sebaya pada siklus I secara umum ada peningkatan baik aktivitas siswa maupun hasil belajar siswa, tetapi peningkatan yang ada belum maksimal yang menurut peneliti ada beberapa penyebab yaitu: (1) masih ada kelompok yang kurang aktif menyampaikan permasalahannya pada tutor; (2) masih ada siswa yang berbicara dengan kelompok lain; (3) waktu belum tertata dengan baik dan hasil belajar belum mencapai indikator keberhasilan yang ditetapkan.

Siklus II

\section{Perencanaan}

Berdasarkan hasil refleksi pada siklus I maka pada siklus II mengupayakan agar siswa lebih aktif dalam kelompoknya, terutama dalam menyampaikan masalah yang dirasakan kepada tutor, memotivasi siswa agar bertanya hanya pada teman dalam saatu kelompok atau pada tutor masing-masing, memaksimalkan waktu yang ada. Perencanaan tindakan pada siklus II peneliti mempersiapkan RPP perbaikan, LKS, Instrumen penilaian berupa 5 butir soal uraian untuk melihat hasil belajar siswa dan mempersiapkan lembar observasi yang akan digunakan untuk melihat aktivitas siswa.

\section{Pelaksanaan}

Pelaksanaan pada siklus II hampir sama dengan dengan pelaksanaan pada siklus I. perbedaannya terletak pada materi pembalajaran, yaitu pertemuan pertama mempelajari tentang persamaan matriks, pertemuan kedua menyelesaiakan system persamaan liniear dua variable dengan matriks, pertemuan ketiga membahas tentang system persamaan linear tiga variable dengan matriks dan dilanjutkan dengan tes evaluasi siklus II.

Observasi 
Vol 1 No 22020 Desember 2020

Jurnal AlphaEuclidEdu

Received: 01/11/2019; Revised: 24/07/2020; Accepted: 02/12/2020

Berdasarkan hasil pengamatan aktivitas belajar siswa pada siklus II, untuk pertemuan pertama rata-rata keaktifan siswa yang termasuk katergori baik dan sangat baik adalah 3,27 atau sekitar 81,88\% dengan kategori baik, Pada pertemuan kedua 3,40 atau $84,90 \%$ dengan kategori baik dan dan pada pertemuan ketiga 3,45 atau 86,46\% dengan kategori amat baik. Data aktivitas siswa pada siklus II dapat dilihat pada tabel berikut.

Tabel IV

Aktivitas belajar siklus II

\begin{tabular}{llc}
\hline Rentang Persen & Kategori & $\begin{array}{l}\text { Jumlah } \\
\text { siswa }\end{array}$ \\
\hline $86 \%-100 \%$ & Amat Baik & 15 \\
$71 \%-85 \%$ & Baik & 13 \\
$56 \%-70 \%$ & Cukup & 2 \\
$41 \%-55 \%$ & Kurang & 0 \\
$<40 \%$ & Sangat. & 0 \\
& Kurang & \\
\hline
\end{tabular}

Tabel IV menunjukkan bahwa aktivitas belajar matematika pada siklus II mengalami peningkatan dibandingkan dengan siklus I. jumlah siswa yang masuk kategori sangat baik ada 15 siswa (50\%), kategori baik ada 13 siswa (43,34\%). Artinya ada 28 siswa $(93,33 \%)$ aktivitas siswa termasuk kategori baik atau sangat baik. Persentase 93,33\% sudah memenuhi indikator penelitian yaitu sebesar $85 \%$ siswa mencapai kategori sangat baik atau baik.

Tabel V

Progres Hasil Belajar Matematika Prasiklus, Siklus I dan Siklus II

\begin{tabular}{lcccc}
\hline \multicolumn{1}{c}{ Uraian } & Pra siklus & Siklus I & Siklus II & Peningkatan \\
\hline Nilai & 22 & 26 & 60 & 38 \\
Terendah & & & & \\
Nilai & 90 & 100 & 100 & 10 \\
Tertinggi & & & & \\
Rata-rata & 44,80 & 64,14 & 78,80 & 34,00 \\
Ketuntasan & $23,34 \%$ & $63,34 \%$ & $83,34 \%$ & $60 \%$ \\
\hline
\end{tabular}

Tabel V, menunjukkan bahwa hasil belajar siswa pada siklus II mengalami peningkatan dibandingkan dengan hasil belajar siswa pada siklus I. nilai terendah pada siklus I yaitu 26 menjadi 60. Rata-rata nilai naik dari 64,14 menjadi 78,80. Persentase banyaknya siswa tuntas juga meningkat dari 63,34\% menjadi $83,34 \%$. Persentase ketuntasan sudah memenuhi indikator penelitian sebesar $\geq 80 \%$ siswa memperoleh nilai tuntas. Hal ini dapat disajikan dalam gambar berikut.

Progres Hasil Belajar Matematika Prasiklus, Siklus I dan Siklus II 
Vol 1 No 22020 Desember 2020

Jurnal AlphaEuclidEdu

Received: 01/11/2019; Revised: 24/07/2020; Accepted: 02/12/2020

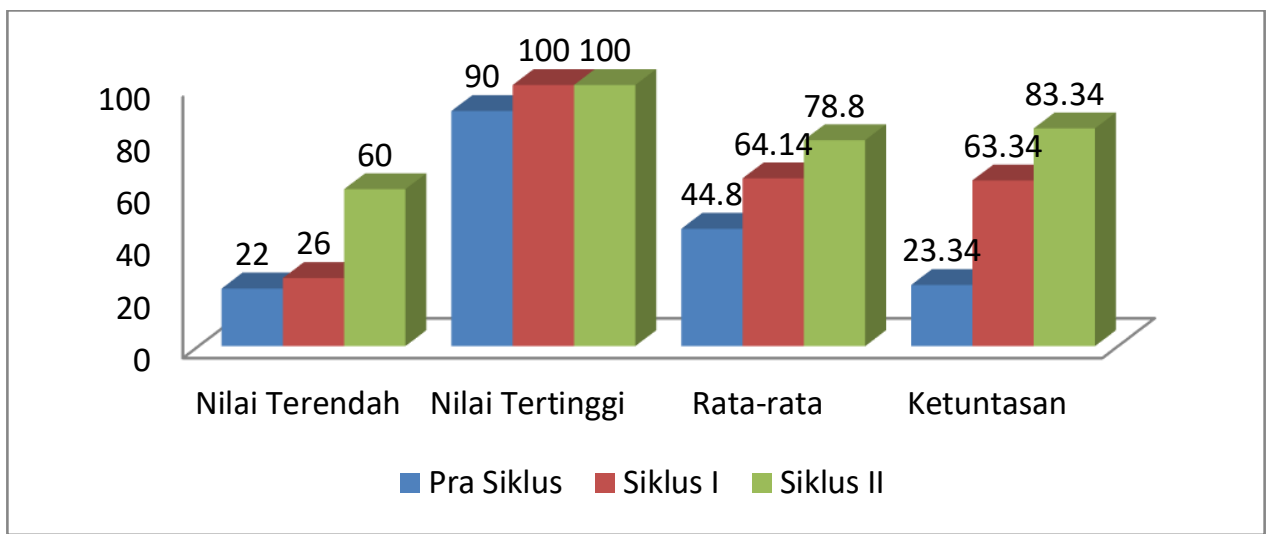

Gambar II. Progres Hasil Belajar Matematika Prasiklus, Siklus I dan Siklus II Refleksi

Aktivitas siswa pada siklus II mengalami peningkatan. Jumlah siswa yang masuk kategori sangat baik ada 15 siswa (50\%), kategori baik ada 13 siswa $(43,34 \%)$, artinya ada 28 siswa $(93,33 \%)$ artinya ada 28 siswa yang termasuk dalam kategori baik dan sangat baik. Persentase 93,33\% sudah memenuhi indikator penelitian. Rata-rata hasil belajar saat prasiklus adalah 44,80 meningkat menjadi 64,14 pada siklus I dan meningkat menjadi 78,80 pada siklus II. Persentase siswa yang tuntas juga mengalami peningkatan. Pada prasiklus persentase siswa sebesar 23,34\% meningkat menjadi $64,34 \%$ pada siklus I dan meningkat kembali pada siklus II menjadi $78,80 \%$ artinya sudah mencapai indikator penelitian.

\section{Kesimpulan}

Berdasarkan hasil penelitian dan pembahasan, maka dapat ditarik kesimpulan sebagai berikut.

Penggunaan model tutor sebaya dapat meningkatkan aktivitas belajar siswa materi matriks pada siswa kelas XI MIA 3 semester I SMA Negeri 1 Sekadau Tahun Pelajaran 2019/2020. Hal ini terlihat dari rata-rata aktivitas belajar siswa pada pra siklus $62,81 \%$ kategori cukup, naik menjadi 76,88\% kategori baik, kemudian naik menjadi $86,46 \%$ kategori amat baik pada siklus II.

Penggunaan model tutor sebaya dapat meningkatkan hasil belajar siswa materi matriks pada siswa kelas XI MIA 3 semester I SMA Negeri 1 Sekadau Tahun Pelajara 2019/2020. Hal ini tampak dari nilai Rata-rata hasil belajar pada pra siklus adalah 44,80 meningkat menjadi 64,14 pada siklus I dan meningkat menjadi 78,80 pada siklus II. Persentase siswa yang tuntas juga mengalami peningkatan. Pada pra siklus persentase siswa sebesar $23,34 \%$ meningkat menjadi $64,34 \%$ pada siklus I dan meningkat kembali pada siklus II menjadi 78,80\%. Disarankan sekolah lebih mengusahakan fasilitas yang dapat mendukung kelancaran kegiatan belajar mengajar dan memotivasi guru untuk selalu berusaha mengembangkan metode pembelajaran yeng aktif. Guru hendaknya selalu meningkat kemampuan yang dimilikinya. Guru yang belum menerapkan metode Tutor sebaya dapat menerapkan metode tersebut dalam pembelajaran matematika atau pelajaran lainnya agar aktifitas meningkat dan hasil belajar sesuai 
Vol 1 No 22020 Desember 2020

Jurnal AlphaEuclidEdu

Received: 01/11/2019; Revised: 24/07/2020; Accepted: 02/12/2020

harapan. Kerjasama guru dan siswa selama proses pembelajaran harus diperhatikan sehingga suasana pembelajaran menjadi lebih kondusif dan siswa dapat lebih mudah memahami materi pembelajaran.

\section{Referensi}

Agus, Suprijono. (2010). Cooperative Learning. Yogyakarta: Pustaka Pelajar

Arikunto Suharsimi, Suhardjono, Supardi. (2006). Penelitian Tindakan. Kelas.Jakarta : Bumi Aksara.

Anggorowati, Ningrum Pusporini. (2011). Penerapan Model Bembelajaran Tutor Sebaya Pada Mata Pembelajaran Sosiologi. Jurnal Komunitas. Vol. 3, No. 1, ISSN: 2086-5465

Benny. A. Pribadi. (2011). Model Desain Sistem Pembelajaran. Jakarta: Dian Rakyat.

Budi Kristina. (2013). Penerapan Metode Pembelajaran Peer Teaching Untuk Meningkatkan Prestasi Belajar Siswa Kelas X MB Pada Standar Kompetensi Mengukur Dengan Alat Ukur Mekanik Di SMKN 2 Wonosari. Skripsi. Yogyakarta: Universitas Negeri Yogyakarta.

Mulyasa. (2008). Praktik Penelitian Tindakan Kelas. Bandung. Rosda Karya Nana Sudjana. (2010). Dasar-dasar Proses Belajar, Bandung: Sinar Baru.

Prasojo,T. (2016). Peningkatan Aktivitas dan hHasil Belajar Matematika dengan Metode Tutor Sebaya pada Siswa Kelas X IPA 7 Materi Trigonometri SMA Negeri 1 Kudus. Jurnal Matematika-Kreatif-Inovatif. 7(1), 31-40. DOI: 10.15294/kreano.v7i1.5049

Retno Sapto Rini Sudiasih. (2012). Penerapan Metode Pembelajaran Tutor Sebaya Untuk Meningkatkan Hasil Belajar Menggambar Busana Di SMK Ma'arif 2 Sleman. Skripsi. Yogyakarta: Universitas Negeri Yogyakarta.)

Sunaryo. (1989). Strategi Belajar Mengajar dalam Pengajaran Ilmu Pengetahuan Sosial. Jakarta: Debdikbud Direktorat Jenderal Pendidikan Tinggi Objek Pengembangan Lembaga Pendidikan Tenaga Kependidikan.

Warsono, dan Hariyanto. (2013). Pembelajaran Aktif: Teori dan Asesmen. Bandung: PT Remaja Rosdakarya. 
Vol 1 No 22020 Desember 2020

Jurnal AlphaEuclidEdu

Received: 07/07/2020; Revised: 28/07/2020; Accepted: 02/12/2020

\title{
KESALAHAN SISWA DALAM MENYELESAIKAN SOAL STATISTIKA TIPE HIGHER ORDER THINKING SKILLS
}

\author{
Damayanti, Safrida Dwi, ${ }^{2}$ Hartoyo, Agung ${ }^{3}$ Suratman, Dede \\ 1,2,3 Pendidikan Matematika FKIP Universitas Tanjungpura Pontianak \\ Email: safidamayanti@gmail.com
}

\begin{abstract}
This study aims to inform student errors in solving statistical problems type HOTS (Higher Order Thinking Skills). There are five varians students ability, that are very high, high, medium, low, and very low. This type of research is a qualitative descriptive study. Subjects in the study involved 36 high school students. The object of this research is the students' errors in solving HOTS type statistical problems. Data collection tecniques used are test tecniques and direct communication teniques (interviews). The results resreach obtained are 3 students with very high ability, 12 students with high ability, 10 students with moderate ability, 6 students with low ability, and 5 students with very low ability to solve statistical problems in the HOTS type. Analytical framework for exposing errors using the Newman method. While the data analysis technique uses qualitative data analysis of Miles and Huberman. Whereas the errors made by students are reading errors $(R)$, comprehension errors $(C)$, transformation errors $(T)$, process skill errors $(P)$, encoding errors $(E)$. The mistakes most students make are process skills errors and encoding errors.
\end{abstract}

Keywords: Error, Higher Order Thinking Skills, Statistika

\section{Pendahuluan}

Matematika memegang sebagian besar peran ilmu dasar yang melambari perkembangan ilmu-ilmu lain dan hampir setiap kegiatan manusia berhubungan dengan matematika. Perwujudan kongkrit dalam hal transaksi pembayaran suatu benda yang sering dilakukan oleh setiap orang, tentunya menggunakan berbagai operasi hitung yang ada di dalam matematika. Sejalan dengan ungkapan yang diutarakan Freudenthal (2000:781) yaitu "Mathematics for life on mathematics as a human activities" perwujudan dari matematika dapat dijumpai dalam kehidupan manusia di lingkungan sekitar. Karenanya materi pelajaran matematika menjadi sangat penting untuk diajarkan di sekolah. Peran penting pelajaran matematika tersebut seharusnya mampu membuat pelajaran matematika menjadi satu diantara mata pelajaran yang mengasikkan dan diminati oleh peserta didik. Namun, sampai saat ini masih banyak peserta didik yang berperasaan bahwa matematika sebagai mata pelajaran yang sulit. Hal tersebut mengakibatkan perolehan nilai peserta didik tidak sesuai dengan apa yang diingikan peserta didik maupun orang tuanya.

Laporan hasil Ujian Nasional yang di sampaikan Pusat Penilaian Pendidikan Kementrian Pendidikan Nasional tahun 2019 menunjukkan bahwa capaian rata-rata nilai siswa pada pelajaran matematika dikategorikan kelas bawah, dengan capaian ratarata sebesar $36,54 \%$ dimana mata pelajaran matematika menempati pencapaian rata-rata terendah dibandingkan dengan mata pelajaran lainnya. Untuk hasil pencapaian siswa terendah di Kalimantan barat dicapai dengan skor 0,0 dari skala 0-100 (Pusat Penilaian Pendidikan Kementrian Pendidikan dan Kebudayaan, 2019). Hal ini menunjukan 
Vol 1 No 22020 Desember 2020

Jurnal AlphaEuclidEdu

lemahnya hasil belajar siswa yang disebabkan adanya kesalahan-kesalahan yang dilakukan oleh peserta didik dalam memproses masalah, terutama soal yang menuntut keterampilan berpikir tingkat tinggi atau biasa disebut dengan soal-soal tipe HOTS.

Kebijakan tentang Kurikulum 2013 yang digagas oleh pemeritahan RI melalui Permendikbud No. 22 tahun 2016 tentang standar proses pendidikan dasar dan menengah, bahwa standart kompetensi kelulusan mencangkup pemikiran siswa untuk menganalisis, mengevaluasi, dan mencipta. Hal ini berarti bahwa rancangan penyempurnaan kurikulum diharapkan siswa dapat mengembangkan diri dalam berpikir tingkat tinggi, siswa diharapkan tidak hanya dapat memiliki kemampuan LOTS, bahkan harus sampai HOTS. Menurut Anderson \& Kratwhwol (2001), menyatakan bahwa indikator untuk mengukur HOTS meliputi menganalisis (analyzing-C4), mengevaluasi (evaluating-C5), dan mengkreasi (creating-C6). Menurut Brookhart (2010:3) bahwa HOTS didefinisikan sebagai transfer, sebagai hal dalam pemikiran kritis, serta sebagai hal dalam memecahkan masalah.

Riset penelitian terdahulu yang dijumpai, seperti penelitian yang dilakukan oleh Muhammad Syahwaluddin (2016) menunjukkan bahwa kemampuan berpikir siswa pada tingkat berpikir HOTS pada sekolah MAN 2 Pontianak tepatnya di kelas XI IPA 3 yaitu: tidak ada siswa yang berada pada tingkatan sangat tinggi, 2 orang siswa $(6,25 \%)$ berada pada tingkatan tinggi, 23 orang siswa $(71,86 \%)$ berada pada tingkatan sedang, 5 orang siswa $(15,63 \%)$ berada pada tingkatan rendah, 2 orang siswa $(6,25 \%)$ berada pada tingkatan sangat rendah, ini menunjukkan rendahnya perolehan nilai siswa yang mengakibatkan berlimpahnya kesalahan yang dilakukan siswa dalam menuntaskan masalah tipe HOTS. Hal ini membuat siswa kurang terlatih dan terbiasa, sehingga ketika mereka menemui soal matematika tipe HOTS, mereka sering melakukan kesalahan dan bahkan tidak dapat menyelesaikan.

Dalam proses pembelajaran matematika seringkali ditemukan siswa mengalami beberapa kesalahan. Misalnya kesalahan siswa dalam membaca dan memahami materi atau soal yang diberikan guru. Ketika siswa salah dalam membaca atau memahami soal yang diberikan akan mengakibatkan hasil penyelesaian yang tidak sesuai dengan harapan guru. Menurut Suyitno \& Hardi (2015: 530-532) bahwa tipe Newman salah satu alternatif untuk menentukan tipe kesalahan siswa dalam menuntaskan masalah matematika secara tertulis. Menurut Newman (1977), kesalahan dalam mengerjakan soal matematika dibedakan menjadi lima tipe kesalahan yang berbeda. Lima tipe tersebut adalah kesalahan: membaca (reading error), transformasi (transformation error), memahami masalah (comprehension error), keterampilan proses (process skills error), dan penulisan jawaban akhir (encoding error).

Menurut Singh (2010:266-267) bahwa kesalahan membaca (R) terjadi ketika siswa tidak mampu membaca maupun menuliskan istilah-istilah yang terdapat pada soal, kesalahan memahami masalah (C) terjadi ketika siswa bisa membaca, akan tetapi salah ataupun tidak kuasa dalam menentukan informasi yang terdapat pada soal, serta tidak dapat mencerna apa yang soal tersebut inginkan, kesalahan transformasi (T) terjadi ketika siswa mampu memahami soal, akan tetapi tidak mampu dalam mengidentifikasi 
operasi hitung yang akan digunakan, kesalahan keterampilan proses $(\mathrm{P})$ terjadi ketika siswa tidak bisa menjalan proses perhitungan dengan tepat meskipun sudah dapat menentukan operasi hitung yang sesuai, dan kesalahan jawaban akhir (E) terjadi ketika siswa tidak bisa menuliskan jawaban dengan tepat.

Berdasarkan pengalaman peneliti pada saat kegiatan Praktik Pengalaman Lapangan (PPL) di SMAN 1 Pontianak siswa cenderung melakukan kesalahan dalam menyelesaikan masalah yang menuntut siswa untuk berpikir kritis, metakognisi, dan kreatif dari yang dipelajarinya, Dari hasil wawancara dengan ibu Sri Sukwantini, S.Pd selaku guru matematika kelas XII SMAN 1 Pontianak diperoleh informasi bahwa siswa dapat menuntaskan masalah, ketika siswa diberikan latihan soal yang mudah (soal yang hanya menuntut siswa mengingat, mengaplikasikan, dan memahami). Akan tetapi ketika siswa diberikan latihan soal tipe HOTS, mereka mulai melakukan kesalahan sehingga tidak menyelesaikan soal tersebut dengan benar". Hal ini juga diperkuat dengan hasil pra-riset di kelas XII MIPA 9 SMAN 1 Pontianak yang dilakukan oleh peneliti pada tanggal 27 September 2019 dengan diberikan 5 soal statistika tipe HOTS kepada 36 siswa. Hasil yang diperoleh 21 dari 36 siswa belum mencapai KKM, ini berarti ada $58,33 \%$ siswa yang belum mencapai KKM pada materi statistika. Hal tersebut mengindikasikan bahwa siswa belum mampu menggunakan kemampuan mereka secara optimal.

Statistika adalah satu diantara cabang dari matematika yang berhubungan dengan metode mengumpulkan, mengolah, menyajikan, menganalisis, dan menyimpulkan data (Sembiring, dkk 2012). Statistika merupakan satu diantara materi yang diujikan dalam Ujian Nasional akan tetapi masih ada siswa yang melakukan kesalahan dalam menyelesaikan soal statistika. hal ini sejalan dengan laporan hasil Ujian Nasional yang di sampaikan Pusat Penilaian Pendidikan Kementrian Pendidikan Nasional menunjukkan bahwa persentase siswa dalam menyelesaikan soal sebanyak 38,50\% untuk mata pelajaran aljabar, 36,54 \% untuk mata pelajaran geometri dan trigonometri, dan terkhusus pada materi statistika yaitu sebesar 36,63\%. Hal ini mengindikasikan bahwa siswa masih melakukan kesalahan ketika menyelesaikan soal statistika.

Dari pemaparan yang terperinci diatas, penulis tertambat untuk melakukan penelitian tentang kesalahan-kesalahan yang siswa buat dalam menuntaskan Soal Statistika tipe HOTS. Sangat penting untuk mengetahui kesalahan siswa dalam menyelesaikan soal matematika khususnya pada soal-soal tipe HOTS karena dapat membantu siswa dalam menentukan langkah apa yang diambil selanjutnya agar dapat meningkatkan kemampuan siswa sehingga berpengaruh juga terhadap hasil belajar.

\section{Metode Penelitian}

Dalam penelitian ini, peneliti menerapkan metode penelitian diskriptip kualitatif. Bentuk penelitian yang dterapkan dalam penelitian ini adalah survei. 36 siswa kelas XII MIPA 8 SMAN 1 Pontianak tahun ajaran 2019/2020 adalah subjek dalam penelitian ini. kemudian diambil 10 siswa dari 36 siswa untuk diwawancarai guna mengkonfirmasi analisis yang penelti lakukan, 10 siswa tersebut terdiri dari 2 orang siswa untuk masing- 
masing tingkatan kemampuan yaitu: sangat tinggi 2 siswa, tinggi 2 siswa, sedang 2 siswa, rendah 2 siswa, dan sangat rendah 2 siswa. Kesalahan - kesalahan yang tertuang dalam lembar jawaban siswa merupakan inti dari objek penelitian ini. Tes dan wawancara adalah instrumen yang peneliti pakai untuk mengumpulkan data-data dalam penelitian ini, tes yang diujikan berupa tes tipe HOTS dan kamunikasi langsung pada penelitian ini adalah wawancara. Menurut Miles and Huberman (1991) tindakan dalam analisis meliputi penyajian data (data display) reduksi data (data reduction), serta penarikan kesimpulan dan verifikasi (conclusion drawing/verification).

Pelaksanaan dalam penelitian ini diawali dengan niat dan persiapan, yakni dengan melakukan pra-riset saat PPL 2019, menyusun desain penelitian yang nantinya akan diseminarkan, setelah melakukan seminar desain proposal pada tanggal 13 september 2019 hasil seminar desain proposal direvisi. Selanjutnya untuk kebutuhan penelitian, maka peneliti menyusun instrumen yaitu berupa tes tipe HOTS dan pedoman wawancara. Instrumen penelitian tersebut di validasi oleh satu orang dosen pendidikan matematika FKIP Untan dan satu orang guru matematika kelas XII SMAN 1 Pontianak. Jika hasil validasi tidak valid, maka dilakukan perbaikan instrumen penelitian. Hasil validasi yang sudah layak langsung diuji cobakan pada siswa kelas XII MIPA 3 SMAN 3 Pontianak. Kemudian dilakukan penelitian di kelas XII MIPA 8 SMAN 1 Pontianak. Hasil dari penelitian langsung diolah untuk menjawab rumusan masalah dan tujuan yang peneliti usung.

Kemudian tes yang di kerjakan siswa, peneliti gunakan untuk alat pengumpulan data dalam penelitian ini. Langkah-langkah yang diterapkan oleh peneliti untuk mengolah data yakni: (1) memberikan 5 lembar yang berisi 2 lembar soal statistika tipe HOTS dan 3 lembar jawaban siswa kepada 36 siswa SMAN 1 Pontianak, (2) memberikan koreksi dengan berpedoman pada rubrik penilaian yang telah divalidasi, (3) mengkategorikan hasil pekerjaan siswa ke dalam tingkat kemampuan siswa dan menganalisis kesalahan yang dilakukan dengan berpedoman metode Newman, (4) memilih 10 orang dari masing-masing kategori untuk dilakukan wawancara berupa tanya-jawab guna mengkonfirmasi hasil analisis yang dilakukan siswa, (5) mendeskripsikan hasil tes, analisis, dan wawancara yang telah diperoleh untuk menarik kesimpulan.

\section{Hasil Penelitian dan Pembahasan}

\subsection{Hasil Penelitian}

Penyelesaian soal statistika tipe HOTS yang dilakukan oleh 36 siswa kelas XII MIPA 8 diperoleh data kesalahan siswa pada nomor 1 sampai nomor 5 berdasarkan indikator kesalahan Newman Error Analysis sebagai berikut: 
Vol 1 No 22020 Desember 2020

Jurnal AlphaEuclidEdu

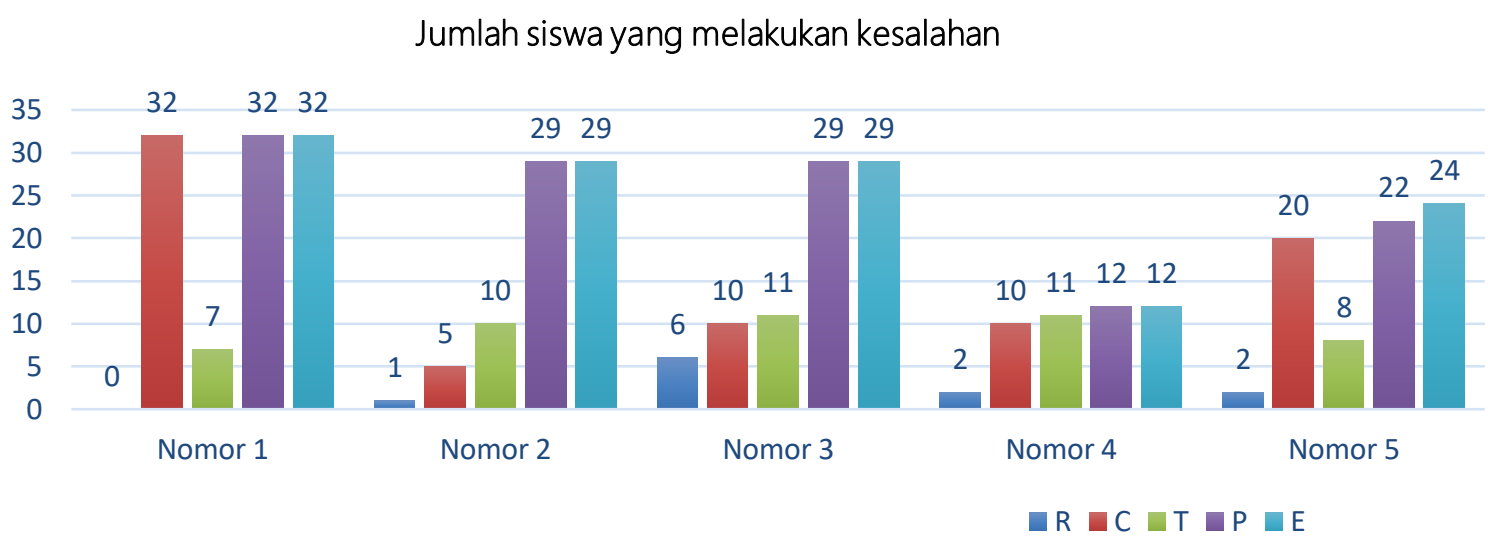

Gambar 1. Kesalahan Siswa Bedasarkan NEA

Berdasarkan gambar 1 diatas dapat diketahui bahwa pada soal nomor 1 jumlah kesalahan tipe $\mathrm{R}$ sebanyak 0 siswa atau $0 \%$, jumlah kesalahan tipe $\mathrm{C}$ sebanyak 32 siswa atau $88,88 \%$, jumlah kesalahan tipe T sebanyak 7 siswa atau $19,44 \%$, jumlah kesalahan tipe $\mathrm{P}$ sebanyak 32 siswa atau $88,88 \%$, dan jumlah kesalahan tipe E sebanyak 32 siswa atau $88,88 \%$.

Untuk soal nomor 2 diketahui bahwa jumlah kesalahan tipe R sebanyak 1 siswa atau 3\%, jumlah kesalahan tipe $\mathrm{C}$ sebanyak 5 siswa atau 13,88\%, jumlah kesalahan tipe T sebanyak 10 siswa atau 28\%, jumlah kesalahan tipe P sebanyak 29 siswa atau $81 \%$, dan jumlah kesalahan tipe E sebanyak 29 siswa atau $81 \%$.

Untuk soal nomor 3 diketahui bahwa jumlah kesalahan tipe R sebanyak 6 siswa atau $16,66 \%$, jumlah kesalahan tipe $\mathrm{C}$ sebanyak 10 siswa atau $28 \%$, jumlah kesalahan tipe T sebanyak 11 siswa atau 31\%, jumlah kesalahan tipe P sebanyak 29 siswa atau $81 \%$, dan jumlah jumlah kesalahan tipe E sebanyak 29 siswa atau $81 \%$.

Untuk soal nomor 4 diketahui bahwa jumlah kesalahan tipe R sebanyak 2 siswa atau 6\%, jumlah kesalahan tipe C sebanyak 10 siswa atau 28\%, jumlah kesalahan tipe $\mathrm{T}$ sebanyak 11 siswa atau 31\%, jumlah kesalahan tipe P sebanyak 12 siswa atau 33\%, dan jumlah jumlah kesalahan tipe E sebanyak 12 siswa atau $33 \%$.

Untuk soal nomor 5 diketahui bahwa jumlah kesalahan tipe R sebanyak 2 siswa atau 6\%, jumlah kesalahan tipe $\mathrm{C}$ sebanyak 20 siswa atau 56\%, jumlah kesalahan tipe $\mathrm{T}$ sebanyak 8 siswa atau 22,22\%, jumlah kesalahan tipe P sebanyak 22 siswa atau $62 \%$, dan jumlah jumlah kesalahan tipe E sebanyak 24 siswa atau $67 \%$.

Dari 36 siswa tersebut dikelompokkan berdasarkan nilai yang diperoleh dari hasil tes, sehingga diperoleh jumlah siswa pada kategori berkemampuan sangat tinggi sebanyak 3 subjek penelitian atau 8\% yaitu: AH, MDN, dan SRP. Untuk siswa pada kategori berkemampuan kelompok tinggi sebanyak 12 subjek penelitian atau 33\% yaitu: IFM, NPP, UAS, GMC, MC, AFG, NVU, SRA, ASS, DSU, MT, dan MNH. Untuk siswa pada kategori berkemampuan kelompok sedang sebanyak 10 subjek penelitian atau 28\% yaitu: NB, RAS, TYH, DGW, SCF, AKM, SAF, PM, AEW, NW. Untuk siswa pada kategori berkemampuan kelompok rendah sebanyak 6 subjek penelitian atau 17\% yaitu: NB, RAS, TYH, DGW, AKM, SAF, PM, AEW, NW. Dan yang terakhir, untuk siswa pada kategori berkemampuan kelompok sangat rendah sebanyak 5 subjek penelitian atau $14 \%$ yaitu: NA, AMK, RA, AI, NFR. Kemudian peneliti mengambil sebanyak 2 siswa pada setiap kategori kemampuan siswa dalam menyelesaikan soal 
Vol 1 No 22020 Desember 2020

Jurnal AlphaEuclidEdu

statistika tipe HOTS, untuk diwawancarai dengan tujuan mengkonfirmasi terkait analisis yang dilakukan oleh peneliti. Adapun perwakilan dari tingkat kemampuan sangat tinggi adalah $\mathrm{AH}$ dan MDN, tingkat kemampuan tinggi adalah GMH dan MC, tingkat kemampuan sedang adalah PM dan TYH, tingkat kemampuan redah adalah AAS dan IDA, dan tingkat kemampuan sangat rendah adalah NFR dan AI. Berikut hasil kesalahan yang siswa lakukan dalam menuntaskan soal statistika tipe HOTS yang akan disajikan dalam bentuk tabel berdasarkan tingkat kemampuan siswa dalam menyelesaikan soal statistika tipe HOTS.

Tabel 1. Data Hasil Tes Soal Statistika Tipe HOTS Berdasarkan Kategori Kemampuan

\begin{tabular}{|c|c|c|c|c|c|c|c|c|c|}
\hline \multirow{2}{*}{$\begin{array}{c}\text { Tingkat } \\
\text { Kemampuan } \\
\text { Siswa }\end{array}$} & \multirow{2}{*}{ No } & \multirow{2}{*}{$\begin{array}{l}\text { Kode } \\
\text { Nama }\end{array}$} & \multirow{2}{*}{ Soal } & \multicolumn{5}{|c|}{$\begin{array}{c}\text { Kesalahan Berdasarkan } \\
\text { tipe Newman }\end{array}$} & \multirow{2}{*}{$\begin{array}{c}\text { Kesalahan } \\
\text { yang } \\
\text { dilakukan } \\
\text { siswa }\end{array}$} \\
\hline & & & & $\mathbf{R}$ & C & $\mathbf{T}$ & $\mathbf{P}$ & $\mathbf{E}$ & \\
\hline \multirow{10}{*}{$\begin{array}{l}\text { Sangat } \\
\text { Tinggi }\end{array}$} & \multirow{5}{*}{1} & \multirow{5}{*}{$\mathbf{A H}$} & 1 & - & $\boldsymbol{V}$ & - & $V$ & $V$ & C, P, E \\
\hline & & & 2 & - & - & - & - & - & - \\
\hline & & & 3 & - & - & - & - & - & - \\
\hline & & & 4 & - & - & - & - & - & - \\
\hline & & & 5 & - & $V$ & - & $V$ & $V$ & C, P, E \\
\hline & \multirow{5}{*}{2} & \multirow{5}{*}{ MDN } & 1 & - & - & - & - & - & - \\
\hline & & & 2 & - & - & - & - & - & - \\
\hline & & & 3 & - & $V$ & - & $\boldsymbol{V}$ & $V$ & C, P, E \\
\hline & & & 4 & - & - & - & - & - & - \\
\hline & & & 5 & - & - & - & - & - & - \\
\hline \multirow{10}{*}{ Tinggi } & \multirow{5}{*}{3} & \multirow{5}{*}{ GMH } & 1 & - & - & - & - & - & - \\
\hline & & & 2 & - & - & - & - & - & - \\
\hline & & & 3 & - & - & - & $V$ & $V$ & P, E \\
\hline & & & 4 & - & - & $V$ & $V$ & $V$ & $T, P, E$ \\
\hline & & & 5 & - & $V$ & - & $V$ & $V$ & C, P, E \\
\hline & \multirow{5}{*}{4} & \multirow{5}{*}{ MC } & 1 & - & $V$ & - & $\boldsymbol{V}$ & $V$ & C, P, E \\
\hline & & & 2 & - & - & $V$ & $V$ & $V$ & T, P, E \\
\hline & & & 3 & - & - & - & - & - & - \\
\hline & & & 4 & - & - & - & - & - & - \\
\hline & & & 5 & - & $V$ & - & $V$ & $V$ & C, P, E \\
\hline \multirow{10}{*}{ Sedang } & \multirow{5}{*}{5} & \multirow{5}{*}{ TYH } & 1 & - & $V$ & - & $V$ & $V$ & C, P, E \\
\hline & & & 2 & - & $V$ & $V$ & $V$ & $V$ & C, T, P, E \\
\hline & & & 3 & - & - & - & - & - & - \\
\hline & & & 4 & - & - & - & - & - & - \\
\hline & & & 5 & - & $V$ & $V$ & $V$ & $V$ & C, T, P, E \\
\hline & \multirow{5}{*}{6} & \multirow{5}{*}{ PM } & 1 & - & $V$ & - & $V$ & $V$ & C, P, E \\
\hline & & & 2 & - & $V$ & $V$ & $V$ & $V$ & C, T, P, E \\
\hline & & & 3 & - & - & - & - & - & - \\
\hline & & & 4 & - & - & - & - & - & - \\
\hline & & & 5 & - & $V$ & $V$ & $\boldsymbol{V}$ & $V$ & C, T, P, E \\
\hline \multirow{2}{*}{ Rendah } & \multirow{2}{*}{7} & \multirow{2}{*}{ IDA } & 1 & - & $V$ & $V$ & $V$ & $V$ & C, T, P, E \\
\hline & & & 2 & - & - & $\boldsymbol{V}$ & $\boldsymbol{V}$ & $V$ & $\mathbf{T}, \mathbf{P}, \mathbf{E}$ \\
\hline
\end{tabular}


Vol 1 No 22020 Desember 2020

Jurnal AlphaEuclidEdu

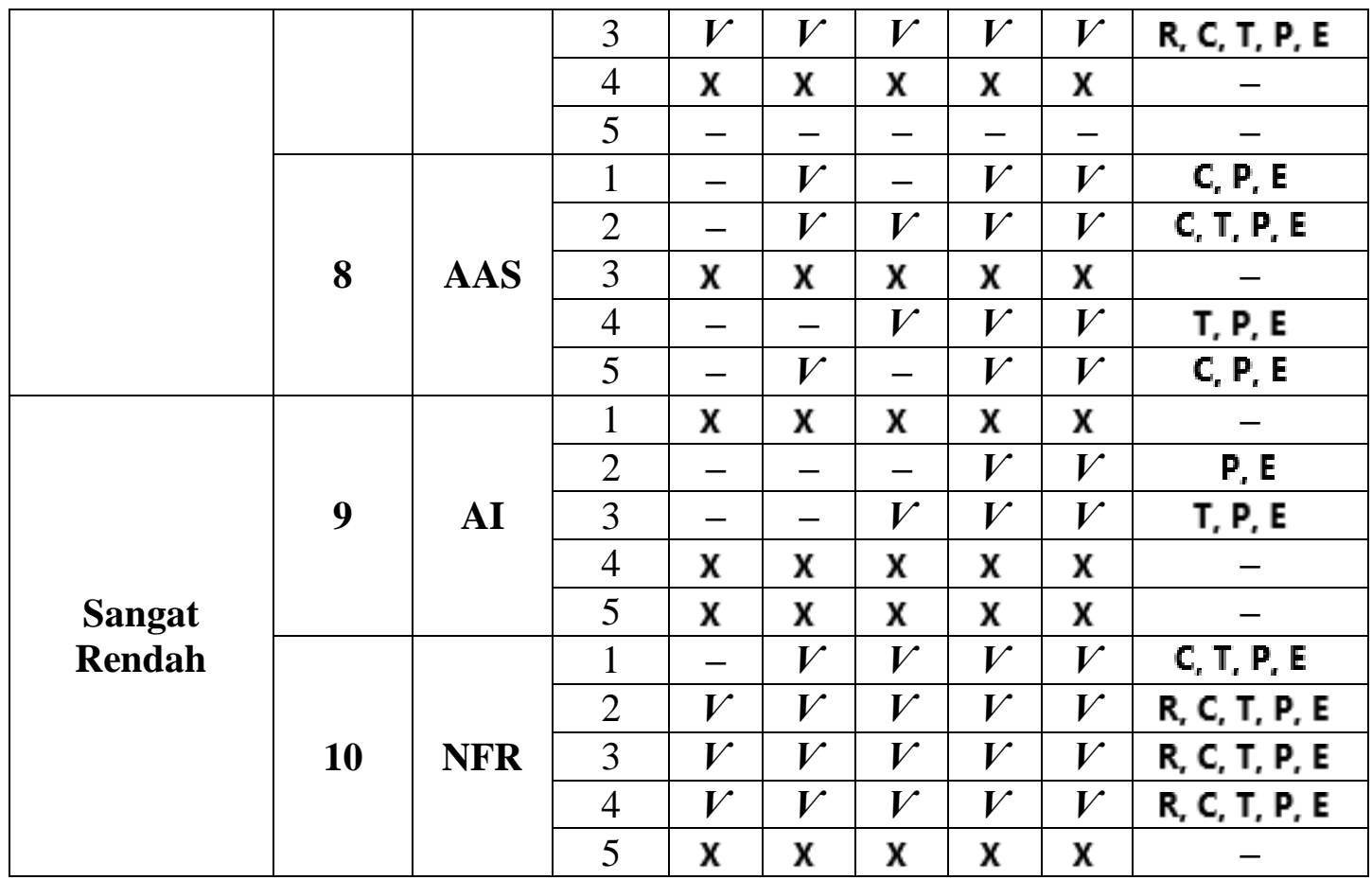

Berdasarkan tabel 1. siswa dengan kemampuan sangat tinggi yaitu AH dan MDN sama-sama melakukan kesalahan: tipe $\mathrm{C}$, tipe $\mathrm{P}$ dan tipe $\mathrm{E}$, ini dikarenakan siswa $\mathrm{AH}$ bingung membedakan rata-rata sebelum 5 siswa mengulang dan rata-rata setelah 5 orang mengulang. seharusnya rata-rata sebesar 7,2 itu rata-rata sebelum 5 siswa mengulang dan untuk rata-rata 7,4 adalah rata-rata nilai setelah 5 siswa mengulang. Selain itu, AH tergesah-gesah dalam proses perhitungan sehingga menyebabkan hasilnya salah. Sedangkan untuk hasil akhir yang ditulis tidak sesuai dengan yang dimaksud dari pertanyaan. Untuk siswa MDN tidak paham informasi yang terdapat dalam soal, MDN tidak mengetahui poin-poin penting pertanyaan dalam soal, sehingga salah dalam proses perhitungan, hal tersebut mengakibatkan siswa MDN tidak sesuai dalam memberikan jawaban akhir. Dalam hal ini siswa dengan kategori berkemampuan tinggi lebih banyak melakukan kesalahan tipe $\mathrm{P}$ dan tipe $\mathrm{E}$.

Untuk siswa dengan kemampuan tinggi yaitu GMH dan MC melakukan kesalahan: tipe $\mathrm{C}$, tipe $\mathrm{P}$, tipe $\mathrm{T}$ dan tipe $\mathrm{E}$. Untuk kesalahan tipe $\mathrm{C}$ yang siswa $\mathrm{GMH}$ lakukan, lantaran siswa GMH tidak dapat memasukkan poin-poin penting yang ada pada soal ke dalam rumus matematika, tepatnya pada rumus statistika. Siswa GMH pada proses perhitungan tidak melanjutkannya, sehingga GMH melakukan kesalahan tipe $P$. Sedangkan untuk kesalahan tipe E, siswa GMH kurang lengkap dalam menuliskan jawaban akhir, sehingga terjadi kesalahan tipe E yang siswa GMH lakukan.

Sedangkan untuk siswa MC kesalahan tipe C yang dilakukannya terjadi karena siswa MC terbalik dalam menuliskan informasi penting, dimana nilai 7,4 seharusnya rata-rata setelah adanya pengulangan, sedangkan nilai 7,2 adalah nilai sebelum adanya pengulangan. Sehingga berakibat proses perhitungan siswa MC menjadi salah. Oleh karena itu siswa MC juga melakukan kesalahan tipe P. Sedangkan untuk kesalahan tipe E yang siswa MC lakukan yakni tidak lengkap memberikan jawaban akhir dan siswa MC salah menuliskan kesimpulan jawaban yang diberikan.

Untuk siswa dengan kemampuan sedang yaitu TYH dan PM melakukan kesalahan tipe $\mathrm{C}$, tipe $\mathrm{T}$, tipe $\mathrm{P}$, dan tipe $\mathrm{E}$. Untuk siswa TYH melakukan kesalahan: tipe $\mathrm{C}$, tipe $\mathrm{T}$, 
tipe $\mathrm{P}$, dan tipe E. Hal ini dikarenakan siswa TYH tidak paham maksud soal nomor 2 ia hanya sebatas mengetahui nilai akhir standar deviasi dikalikan 2 dan kemudian dikurangi 15, akan tetapi siswa TYH tidak mampu memasukkan poin-poin penting kedalam rumus statistika. Akibatnya siswa TYH melakukan kesalahan tipe C dan tipe T. untuk tipe $\mathrm{P}$ dan tipe E, siswa TYH salah dalam perhitungan, ia tidak dapat menjalankan prosedur penyelesaian dengan tepat serta jawaban yang diberikan siswa TYH tidak sesuai. Hal ini menyebabkan siswa TYH kurang tepat.

Sedangkan untuk siswa PM melakukan kesalahan tipe C, tipe P dan tipe E. Untuk kesalahan tipe $\mathrm{C}$ yang dilakukan siswa PM terjadi disebabkan oleh kebingungan siswa PM dalam membedakan rata-rata sebelum 5 siswa mengulang dan rata-rata setelah 5 orang mengulang. seharusnya rata-rata sebesar 7,2 itu rata-rata sebelum 5 siswa mengulang dan untuk rata-rata 7,4 adalah rata-rata nilai setelah 5 siswa mengulang. Selain itu, siswa PM terburu-buru dalam proses perhitungan sehingga menyebabkan hasilnya salah. Sehingga jawaban akhir yang siswa PM tuliskan tidak sesuai dengan permintaan soal. Terlepas dari kesalahan tipe $\mathrm{C}$ tersebut, siswa PM juga melakukan kesalahan tipe P. Dimana dalam perhitungannya siswa PM salah dalam menghitung $\frac{294}{40}$ yang seharusnya diperoleh 7,35 akan tetapi justru siswa PM menuliskan 7,5. Hal ini menyebabkan siswa PM salah dalam memberikan jawaban akhir yang tepat. Sehingga tipe $\mathrm{P}$ dan tipe $\mathrm{E}$ lebih dominan dilakukan oleh siswa yang berkemampuan sedang seperti yang diuraikan diatas.

Untuk siswa dengan kemampuan rendah yaitu IDA dan AAS melakukan kesalahan: tipe R, tipe C, tipe T, tipe P, dan tipe E. Siswa IDA melakukan kesalahan: tipe R, tipe C, tipe $\mathrm{T}$, tipe $\mathrm{P}$ dan tipe E. Untuk tipe R, siswa IDA tidak mengetahui istilah, lambang, ataupun simbol yang terdapat dalam soal. Siswa IDA tidak mengetahui istilah standar devisiasi, ia bingung membedakannya antara simpangan baku dan simpangan rata-rata. Untuk tipe C, siswa IDA melakukan kesalahan dikarenakan ia menyelesaikannya soal nomor 2 dengan cara mencari terlebih dahulu berapa mahasiswa yang lulus dari informasi $60 \%$ sehingga diperoleh 180 mahaiswa yang dinyatakan lulus, akibatnya interval data terletak pada 66 - 75. Kemudian siswa IDA langsung berkesimpulan bahwa nilai terendahnya tu 66. Ini berarti siswa IDA tidak mampu memahami soal dengan benar. Untuk tipe T, siswa IDA sudah benar dalam menentukan rumus yang digunakan, akan tetapi siswa IDA belum bisa memasukkan data yang ada ke dalam rumus statistika yang digunakan. Untuk tipe $\mathrm{P}$, proses perhitungan yang dilakukan siswa IDA masih tidak tepat. Untuk tipe E, terjadi ketika jawaban akhir yang diberikan siswa IDA jawaban yang kurang tepat dan kurang lengkap. Siswa IDA menuliskan " $3 \%$ atau $9 \%$ " dimana seharusnya tertulis $3 \%$ atau $8 \%$ " sehingga siswa IDA kurang tepat dalam memberikan jawaban.

Sedangkan siswa AAS melakukan kesalahan: tipe $\mathrm{C}$, tipe $\mathrm{T}$, tipe $\mathrm{P}$ dan tipe $\mathrm{E}$. Untuk tipe $\mathrm{C}$, siswa AAS bingung membedakan rata-rata sebelum 5 siswa mengulang dan rata-rata setelah 5 orang mengulang, seharusnya rata-rata sebesar 7,2 itu rata-rata sebelum 5 siswa mengulang dan untuk rata-rata 7,4 adalah rata-rata nilai setelah 5 siswa mengulang. Untuk tipe P, terjadi dikarenakan siswa AAS salah dalam mengoperasikan operasi pembagian. Untuk tipe E, terjadi dikarenakan siswa AAS hanya menuliskan jawaban "3\%" yang seharusnya tertulis " $3 \%$ atau $8 \%$ ". Siswa tidak menduga bahwa ada kemungkinan lain yang dipertanyakan dalam soal. Sehingga dari penjabaran diatas dapat disimpulkan bahwa kesalahan tipe $\mathrm{C}$, tipe $\mathrm{T}$, tipe $\mathrm{P}$, dan tipe $\mathrm{E}$ lebih dominan dilakukan siswa berkemampuan sedang yang dilanjutkan. 
Untuk siswa dengan kemampuan sangat rendah yaitu AI dan NFR melakukan kesalahan tipe $\mathrm{R}$, tipe $\mathrm{C}$, tipe $\mathrm{T}$, tipe $\mathrm{P}$, dan tipe $\mathrm{E}$. Untuk siswa AI melakukan kesalahan: tipe $\mathrm{T}$, tipe $\mathrm{P}$, dan tipe $\mathrm{E}$. Untuk tipe $\mathrm{T}$, siswa AI tidak mengetahui rumus dari standar deviasi sehingga siswa AI tidak bisa memasukkan informasi penting kedalam rumus. Untuk tipe $\mathrm{P}$, siswa AI tidak mempunya cukup waktu untuk menyelesaikan soal, ia tergesah-gesah dalam melakukan perhitungan terutama pada operasi perpangkatan dan perkalian, ia tidak teliti dalam menghitungnya. Untuk tipe E, siswa AI salah menuliskan jawaban akhir yang diminta, karena pada proses perhitungan siswa AI sudah salah.

Sedangkan untuk siswa NFR, melakukan kesalahan: tipe R, tipe T, tipe C, tipe $\mathrm{P}$, dan tipe E. Untuk tipe R, siswa NFR tidak mengetahui istilah, lambang, ataupun simbol yang terdapat dalam soal. Siswa NFR tidak mengetahui istilah standar devisiasi, siswa NFR tidak pernah mendengar atau menjumpai istilah standar deviasi. Untuk tipe $\mathrm{C}$, siswa NFR bingung membedakan rata-rata sebelum 5 siswa mengulang dan rata-rata setelah 5 orang mengulang, seharusnya rata-rata sebesar 7,2 itu rata-rata sebelum 5 siswa mengulang dan untuk rata-rata 7,4 adalah rata-rata nilai setelah 5 siswa mengulang. Untuk tipe T, karena siswa NFR bingung membedakan rata-rata sebelum dengan sesudah yang terdapat dalam soal, maka siswa NFR juga salah dalam memasukkan informasi penting yang terdapat dalam soal. Untuk tipe P, siswa NFR salah menentukan batas atas dengan batas akhir, sehingga ketika proses perhitungannya menjadi tidak benar. Untuk tipe E, siswa NFR memberikan jawaban tidak benar dikarenakan ketika proses perhitungannyapun salah. Dalam hal ini siswa dengan kategori berkemampuan sangat rendah lebih banyak melakukan kesalahan tipe $\mathrm{C}$, tipe $\mathrm{P}$ dan tipe E.

\subsection{Pembahasan}

Berdasarkan perolehan penelitian diatas, menunjukkan tengah ada siswa yang melakukan kesalahan dalam menuntaskan soal yaitu kesalahan: tipe $\mathrm{R}$, tipe $\mathrm{C}$, tipe $\mathrm{T}$, tipe $\mathrm{P}$, dan tipe $\mathrm{E}$. Tipe $\mathrm{P}$ dan Tipe $\mathrm{E}$ adalah kesalahan yang paling dominan dilakukan siswa. Dari penelitian yang dilakukan oleh Maya Mulyani dan Dedi Muhtadi (2019) tentang analisis kesalahan siswa menyelesaikan soal tipe HOTS pada materi trigonometri ditinjau dari gender diperoleh bahwa berdasarkan kategori kesalahan Newman, letak tahapan kesalahan siswa dalam menyelesaikan soal trigonometri yaitu kesalahan: tipe $\mathrm{T}$, tipe $\mathrm{P}$, tipe $\mathrm{C}$, dan tipe $\mathrm{E}$.

Penelitian lainnya Wilda Mahmudah (2018) tentang berdasarkan teori Newman peneliti ini melakukan analisis kesalahan siswa dalam menyelesaikan soal matematika bertipe HOTS. Berdasarkan teori Newman diperoleh bahwa kesalahan tipe $\mathrm{C}$ dan tipe $\mathrm{T}$ lebih dominan dibandingkan dengan 5 kesalahan lainnya. Dalam penelitiannya persentase kesalahan yang diperoleh adalah $8,5 \%$ siswa melakukan kesalahan tipe $\mathrm{P}$, $30 \%$ siswa melakukan kesalahan tipe $\mathrm{T}, 65 \%$ siswa melakukan kesalahan tipe C, dan $10 \%$ siswa melakukan kesalahan tipe E.

Adapun penelitian lainnya oleh Kharisah imroatul Mu'minah (2018) yang mengungkap kesalahan siswa menyelesaikan soal matematika pada pokok materi 
Vol 1 No 22020 Desember 2020

Jurnal AlphaEuclidEdu

barisan aritmatika sosial tipe HOTS, diperoleh bahwa pada aspek C4 siswa melakukan kesalahan tipe $\mathrm{C}$ dan tipe $\mathrm{T}$, pada aspek $\mathrm{C} 5$ siswa melakukan kesalahan tipe $\mathrm{C}$ dan tipe T, sedangkan pada aspek C6 siswa melakukan kesalahan tipe T saja.

Berdasarkan tujuan penelitian, yang ingin mengungkap kesalahan yang siswa lakukan ini diperoleh kesalahan-kesalahan yang sama, hanya saja untuk persentase pada kesalahan siswa ketika menyelesaikan soal tipe HOTS pada materi statistika berbedabeda. Dan tentunya dengan faktor yang berbeda-beda pula

\section{Kesimpulan}

Berdasarkan perolehan dan pembahasan penelitian pada bab IV, maka dapat diambil kesimpulan bahwa kesalahan yang dilakukan siswa pada penelitian ini mencakup semua jenis kesalahan berdasarkan Newman's Error Analyisis. Kesalahan dari yang tertinggi diantaranya kesalahan keterampilan proses (P), kesalahan jawaban akhir (E), kesalahan memahami masalah (C), kesalahan transformasi (T), kesalahan membaca (R). Untuk tipe $\mathrm{P}$ dan tipe $\mathrm{E}$ adalah tipe kesalahan yang dominan dilakukan siswa. Siswa melakukan kesalahan tipe $\mathrm{P}$ dan tipe $\mathrm{E}$ dikarenakan tidak meneruskan penyelesaian atau mengalami kemacetan dalam perhitungan, serta ketika jawaban akhir yang tertulis tidak tepat atau jawaban akhir yang tertulis tidak sesuai dengan yang dinginkan soal. Untuk kesalahan di masing-masing tingkatan kemampuan sebagai berikut: (1) Kesalahan yang dilakukan siswa dengan kemampuan tergolong sengat tinggi dalam menyelesaikan soal statistika tipe HOTS adalah kesalahan tipe C, tipe P, dan tipe E. Untuk tipe $\mathrm{P}$ dan tipe $\mathrm{E}$ adalah tipe kesalahan yang dominan dilakukan siswa berkemampuan sangat tinggi. (2) Kesalahan yang dilakukan siswa dengan kemampuan tergolong tinggi adalah kesalahan tipe $\mathrm{C}$, tipe $\mathrm{T}$, tipe $\mathrm{P}$, dan tipe $\mathrm{E}$. Untuk tipe $\mathrm{P}$ dan tipe E yakni tipe kesalahan yang dominan dilakukan siswa berkemampuan tinggi. (3) Kesalahan yang dilakukan siswa dengan kemampuan tergolong sedang adalah semua kesalahan yaitu kesalahan tipe $\mathrm{R}$, tipe $\mathrm{C}$ tipe $\mathrm{T}$, tipe $\mathrm{P}$, dan tipe $\mathrm{E}$. Untuk tipe $\mathrm{C}$, tipe $\mathrm{P}$ dan tipe E yakni tipe kesalahan yang dominan dilakukan siswa berkemampuan sedang. kemudian dilanjutkan dengan kesalahan tipe $T$ dan tipe R. (4) Kesalahan yang dilakukan siswa dengan kemampuan tergolong rendah adalah semuanya yaitu kesalahan tipe $\mathrm{C}$, tipe $\mathrm{T}$, tipe $\mathrm{P}$, dan tipe E. Adapun jenis kesalahan yang lumrah dilakukan siswa dengan kemampuan rendah adalah kesalahan, tipe $\mathrm{C}$, tipe $\mathrm{T}$, tipe $\mathrm{P}$, dan tipe $\mathrm{E}$. (5) Kesalahan yang dilakukan siswa dengan kemampuan tergolong tinggi adalah semuanya yaitu kesalahan tipe $\mathrm{R}$, tipe $\mathrm{C}$, tipe $\mathrm{T}$, tipe $\mathrm{P}$, dan tipe $\mathrm{E}$. Adapun jenis kesalahan yang lumrah dilakukan siswa dengan kemampuan sangat rendah adalah kesalahan, tipe C, tipe $\mathrm{T}$, tipe $\mathrm{P}$, dan tipe $\mathrm{E}$. lantas dilanjutkan dengan kesalahan tipe $\mathrm{R}$.

\section{Referensi}

Anderson, L. W., \& Krathwohl, D. R. (Eds.). (2001). A taxonomy for learning, teaching, and assessing: A revision of Bloom's Taxonomy of Educational Objectives (Complete ed.). New York: Longman.

Brookhart, S.M. (2010). How to assess higher-order thingking skills in your classroom. Virginia USA: ASCD Alexandria. 
Vol 1 No 22020 Desember 2020

Jurnal AlphaEuclidEdu

Clemen, M. N. (1980). The Newman Procedure For Analysing Errors On Written Mathematical Tasks. Educational Studies in Mathematics Computer Applicationsin Engineering Sciences. 2(1): 17-21.

Freudenthal, H. (1991). Developing Realistics Mathematics Education. Utrecht: CD-B Press. Freudenthal Institute.

Laporan Hasil Ujian Nasional dari Pusat Penilaian Pendidikan Kementrian Pendidikan dan Kebudayaan (Online) (https://hasilun.puspendik.kemdikbud.go.id/\#2019 Diambil pada tanggal 16 juli 2019).

Mahmudah, Wilda. (2018). Analisis Kesalahan Siswa dalam Menyelesaikan Soal Matematika Tipe HOTS Berdasarkan Teori Newman. Jurnal UJMC 4 (1): 49-56.

Miles, M.B and A. Michael Huberman. (2005). Qualitative Data Analysis (terjemahan). Jakarta: UI Press

Mulyadi, Maya dan Dedi Muhtadi. (2019). Analisis Kesalahan Siswa dalam Menyelesaikan Soal Trigonometri Tipe HOTS Ditinjau dari Gender. JPPM 12(1):1-16.

Mu'minah, K I. (2018). Kesalahan Siswa dalam Menyelesaikan Soal Matematika tipe HOTS Pada Pokok Bahasan Aritmatika Sosial. UMS: 1-12.

Sembiring, Suwah dkk. (2012). Matematika Berbasis Pendidikan Karakter Bangsa. Untuk SMA/MA. Kelas XI. Bandung: Yrama Widya

Singh, Parmjit dkk. (2010). The Newman Procedure for Analyzing Primary Four Pupils Errors on Written Mathematical Tasks: A Malaysian Perspective. Procedia Social and Behavioral Sciences 8 (2010) 264-271 International Conference on Mathematics Education Research 2010 (ICMER 2010)

Syahwaludin, M. (2016). Higher Order Thinkhing Skills Siswa pada Materi Statistika Kelas XI IPA MAN 2 Pontianak. Jurnal Pendidikan dan Pembelajaran, 5 (11): 1-10.

Suyitno, Hardi. 2015. Learning Therapy for Students in Mathematics Communication Correctly Based-on Aplication of Newman Procedure (A Cace of Indonesia Student). International of Education and Research). 
Vol 1 No 22020 Desember 2020

Jurnal AlphaEuclidEdu

Received: 21/10/2020; Revised: 19/11/2020; Accepted: 02/12/2020

\title{
KEMAMPUAN MENYELESAIKAN SOAL PISA PADA KONTEN CHANGE AND RELATIONSHIP
}

\author{
${ }^{1}$ Teresa, Helyana, ${ }^{2}$ Zubaidah, ${ }^{3}$ Nursangaji, Asep \\ ${ }_{1,2,3}$ Pendidikan Matematika FKIP Universitas Tanjungpura Pontianak \\ Email: helyanateresa61@gmail.com,
}

\begin{abstract}
This Educators are required to be able to form a generation that can act effectively in the face of world changes that are so fast and complex. The PISA study that has been conducted has not used a sample that depicts all Indonesian students. Especially for students who are in SMP Negeri 4 Jawai not yet become a sample in the PISA study. This study aims to describe and find out how the ability to solve the Program for International Student Assessment (PISA) content on change and relationship content by junior high school students. The research method used in this research is descriptive qualitative research survey. Subjects in this study were 26 subjects. The results of the discussion showed that the ability to solve PISA questions for students was said to be still very low. This is because students have not been able to understand the problem correctly, students have not been able to identify and select relevant information because mathematical models in context are available, students have difficulty in giving arguments at every step of solving problems and drawing conclusions.
\end{abstract}

Keyword: Change and Relationship, Menyelesaikan Soal, PISA

\section{Pendahuluan}

Menurut Heppel, dkk (2004) Pendidik diharap dapat mendoktrin generasi yang cakap bekerja selaku efisien untuk menyongsong peralihan global yang sedemikian kompleks dan cepat. Pendidikan pada dasarnya merupakan satu diantara cara untuk menumbuhkembangkan kapasitas peserta didik yaitu melalui cara menggerakkan dan menyediakan kegiatan suatu kegiatan belajar mengajar kepada mereka (Hamidy, 2016). The partnership for 21st century skills menyatakan pembelajaran harus focus mengelaborasikan 4C sebagai kompetensi untuk mengembari ranah abad 21 yaitu communication, critical thinking, creativity, and collaboration. Matematika merupakan satu diantara pelajaran yang sanggup mencapai kriteria tersebut di sekolah.

OECD (2013) mengungkapkan bahwa matematika bagian penting bagi remaja dalam menyambut rumor dan persoalan baik di cangkupan aktivitas keseharian, masyarakat, pekerjaan. Sepemikiran dengan hal ini visi pembelajaran matematika di sekolah yang dikembangkan NCTM (2000: 5) yang dapat diartikan sebagai berikut "Pada dunia yang terus menerus mengalami perubahan ini, mereka yang dapat memahami dan mahir bermatematika mempunyai peluang atau opsi yang meningkat secara tajam untuk merancang masa depan mereka. Kompetensi matematika memelopori batu loncatan menuju masa depan yang inventif. Kompetensi matematika yang kurang menyebabkan pintu-pintu itu tertutup." Sehingga kompetensi matematika berpengaruh untuk aktivitas keseharian perlu untuk peningkatankan sebagai satu diantara evaluasi untuk merancukan kearifan pendidikan pada abad 21.

Guru diharapkan dapat mengintensifkan siswa memecahkan soal demi keterampilan berpendapat perseptif, rasional, terorganisasi dan tertata dan menguasai konsep untuk 
penataran matematika. Ujian Nasional (UN) saat ini masih sebagai salah satu parameter kesuksesan anak didik pada tujuan pembelajaran matematika. Lembaga internasional yang berkecimpung di dalam sektor pendidikan sebagai takaran bagaimana kemampuan matematika siswa di Indonesia dengan negara lain di dunia, diantaranya adalah menyertai ujian Programme for International Student Assessment (PISA).

Peran serta Negara Indonesia tatkala partisipasi menyertai ujian yang diadakan oleh juga PISA framework 2012 menjelaskan bahwa kerangka soal PISA matematika memiliki tiga perspektif antara lain: (1) isi (content), (2) situasi (context), dan (3) kelompok kompetensi (competency cluster). Soal PISA diperbanyak berpedoman pada empat konten matematika, yaitu: Uncertainty and Data, Space and Shape, Quantity, dan Change and Relationships. PISA memperlihatkan bahwa pada umumnya skor performa literasi matematika di Negara Indonesia pada tahun 2009 peringkat 61 dari 65, pada tahun 2012 peringkat 64 dari 65, dan pada tahun 2015 Indonesia peringkat 63 dari 70 negara peserta (OECD). Kemampuan siswa Indonesia dalam menyelesaikan soal PISA sangat kurang dipandang dari peringkat pada ujian yang tertera.

Wahyuni (2011) menyebutkan kenyataan mengindikasikankan bahwa satu di antara kesusahan yang timbul pada siswa di pembelajaran matematika ialah mengerjakan soal. Kesusahanya bukan hanya pada soal kesusahan, tapi juga kesusahan pada model matematika yang mempunyai arti terkait dengan satu soal. Kemampuan menyelesaikan soal bisa dipandang sebagai satu diantara dari proses dan hasil belajar. Menurut Kirkley (2003) menyelesaikan soal mengecap proses berpikir tingkat tinggi seperti proses penggambaran, afiliasi, abstraksi, manipulasi, penalaran, penjabaran, paduan, dan menyamaratakan yang masing-masing dikelola secara terkoordinasi.

Berdasar perjelasan tersebut dapat ditarik kesimpulan bahwa Negara Indonesia masih berada di bawah standar pada umunya dalam hal kompetensi internasional. Peserta didik di Negara Indonesia masih belum dapat mengatasi persoalan matematis dalam keseharian. Hal tersebut didasarkan pada soal yang belum tersedia untuk menimbang kecakapan menyelesaikan soal matematika peserta didik serupa soal nonrutin model PISA. Bersumber pada pengalaman PPL di sekolah guru belum mampu menangkap atau menguasai bahkan tidak mengetahui perkara soal model PISA. Sehingga soal yang dibagikan pada peserta didik berupa soal rutin.

Mengenai yang akan jadi ruang cangkupan dalam penelitian ini yaitu kemampuan menyelesaikan soal PISA pada muatan relationship and change, tujuan pengambilan muatan relationship and change pada penelitian ini karena materi aljabar merupakan materi yang masih dianggap sulit bagi anak didik. Fakta tersebut dapat dilihat pada hasil riset PISA yang memperlihatkan peserta didik yang bisa mengerjakan soal dengan tepat pada geometri sejumlah $47,5 \%$, bilangan $53,7 \%$ dan statistic $61,9 \%$. Hanya $41,4 \%$ siswa yang menjawab benar pada soal aljabar. Siswa ditekankan untuk sanggup membuat model matematika, merampungkan model dan menguraikan penyelesaian yang diperoleh, dan memahami soal sehingga kemampuan pemecahan soal matematis di Indonesia disebutkan bisa untuk menyelesaikan soal bertaraf internasional satu diantaranya soal yang diujikan PISA. 
Vol 1 No 22020 Desember 2020

Jurnal AlphaEuclidEdu

Studi PISA yang telah dilakukan belum menggunakan sampel yang menggambarkan seluruh siswa Indonesia. Terutama untuk siswa yang ada di SMP Negeri 4 Jawai belum menjadi sampel dalam studi PISA. Karena peneliti penasaran bagaimana kemampuan mengerjakan soal PISA untuk konten change and relationship oleh siswa SMP Negeri 4 Jawai. Maksud dalam riset ini ialah mendeskripsikan kemahiran mengerjakan soal PISA dalam muatan relationship and change oleh siswa sekolah menengah pertama.

Menyelesaikan soal bisa dilihat sebagai rekayasa informasi secara runtut, tahap demi tahap dengan mengolah informasi yang dibutuhkan melalui pandangan untuk mencapai suatu hasil pemikiran sebagai respon terhadap persoalan yang dihadang (Nasution, 2006: 7). Menyelesaikan soal ialah prosedur mengaplikasikan pengetahuan yang telah didapat sebelumnya ke dalam kondisi baru yang belum diketahui. Karakter pada soal atau tugas yang didalamnya berbentuk menyelesaikan soal adalah: (1) ada tantangan pada materi latihan dan (2) soal tidak mungkin diselesaikan menggunakan prosedur yang telah diketahui oleh penjawab (Wardhani, 2010: 40). Soedjadi (2000: 36) mengungkapkan bahwa kemampuan menyelesaian soal ialah suatu kapabilitas pada peserta didik agar bisa memakai tindakan matematis untuk menyelesaikan soal pada matematika, persoalan ilmu lainya dan dalam keseharian.

Berdasarkan sejumlah pengertian menyelesaikan soal tersebut diatas, dapat disebutkan bahwa Menyelesaikan soal ialah upaya jelas pada bentuk mengetahui lintasan keluar atau gagasan berbarengan dengan destinasi yang hendak dicapai. Menyelesaikan soal merupakan suatu prosedur yang kompleks mengupayakan perorangan untuk menyingkronkan kemahiran, kepandaian, interpretasi, dan naluri seraya rangka menyanggupi desakan dari suatu situasi.

Menurut Suherman (2001: 93) menyelesaikan soal adalah komponen terpenting dari kurikulum matematika karena pada tahapan pembelajaran maupun menyelesaikannya, peserta didik diharapkan mendapatkan profesionalisme memakai pengetahuan juga kecakapan yang telah didapatkan untuk diaplikasikan pada menyelesaikan soal yang bersifat tidak rutin. Keterampilan matematika yang esensial mengimplementasikan aturan dalam soal tidak rutin, menemukan pola, penyamarataan, korespondensi matematika sehingga dapat berkembang dengan lebih efektif.

Seraya adanya impresi prinsip belajar kognitif, sehingga terjalin motifikasi ideologi terhadap arti menyelesaikan soal yang membidik pada kesibukan mental bersifat kompleks menyeluruhi berbagai kefasihan dan aktivitas psikologis. Garofalo dan Lester (2003), menyebutkan menyelesaikan soal meliputi proses berpikir tingkat tinggi seperti proses pencitraan, federasi, resume, muslihat, berpikit logis, penyelidikan, paduan dan generalisasi yang sendirinya penting ditata secara terkoordinasi.

Wu (2010) menyatakan OECD adalah organisasi antar pemerintah negara yang memiliki ketertatikan pada keputusan kebijakan sebagai tujuan utama. Dalam penelitian ini focus adalah untuk mengetahui kompetensi sains, membaca dan matematika, anak umur 15 tahun (Ahyan, dkk. 2014). Masing-masing potensi yang diriset dari PISA ialah kemampuan sangat krusial untuk kesibukan bangsa setelah pendidikan formal. 
Pusztai dan Bacskai (2015) menyatakan untuk mengevaluasi kemampuan pelajar saat mengaplikasikan kecakapan dan kepandaian pada situasi lingkungan pekerjaan dan menyuguhkan buatan kualitas karakter yang bisa dikomparasi bersama kawasan lainnya ialah tujuan PISA. PISA bersama dengan pelajaran matematika memiliki tujuan yang sama yaitu menyampaikan keterangan tentang kesanggupan anak didik untuk mengimplementasikan matematika pada beragam kondisi Wijaya (2014). Sehingga, penelitian PISA pada lingkungan kemampuan matematika memiliki tujuan memperkirakan kemampuan anak didik untuk menggunakan konsep matematika saat menyelesaiakan permasalahan keseharian.

Konteks PISA dalam matematika menyampaikan penjelasan dan alasan saat melakukan suatu penilaian yakni bagaimana peserta didik berusia 15 tahun menggarap persoalan yang bersifat matematis baik ketika berhadapan dengan persoalan yang mengemuka didunia nyata atau secara keseluruhan suatu evaluasi tentang bagaimana peserta didik usia 15 tahun yang mempunyai kemahiran literasi matematis. Untuk menggambarkan secara spesifik tentang permasalahan tersebut, pada (OECD, 2010:90) terdapat beberapa unsur yang mesti dibedakan: (1) Situasi atau konteks duduk persoalan; (2) Konten matematika dimanfaatkan untuk menyelesaikan persoalan yang terhimpun oleh inspirasi terpilih selaku keseluruhan, dimana persoalan tersebut terhubung dengan matematika yang akan dipecahkan bermunculan; (3) Kompetensi matematika mesti digiatkan untuk dapat terjaring dengan dunia nyata.

Proses matematisasi berhubungan dengan permodelan matematika, yang mana proses dimulai lewat kejadian dunia nyata, diakhiri dengan penyelesaian yang sesuai beserta fakta yang ada dan melewati beberapa tingkatan. Proses matematisasi dalam literasi matematika terbagi menjadi tiga tahapan utama untuk menyelesaikan soal matematika, yaitu formulate, interpret dan employ.

Tahap "formulate" menunjukkan pada kepiawaian pribadi untuk mengingat, mengidentifikasi peluang saat mengaplikasikan matematika dan menampilkan pola matematika terhadap persoalan kontekstual yang dihadapan. Selanjutnya proses "interpret" melihat kompetensi perorangan untuk merefleksikan penyelesaian, hasil dan simpulan matematika juga menginterprestasikannya kedalam persoalan di keseharian. Proses "employ" menyatakan pada kompetensi perorangan pada menggunakan fakta, konsep, penalaran dan tahapan matematika untuk mengakhiri masalah yang sudah dirumuskan sehingga memdapatkan pemecahan matematis. (Edo, Hartono, \& Putri, 2013).

\section{Metode Penelitian}

Bentuk penelitian yang berperankan pada penelitian ini adalah penelitian kualitatif. Menurut subana dan sudrajat (2011: 17), penelitian kualitatif merupakan penelitian yang bersifat deskriptif karena data yang diulas berupa deskripsi dari indikasi yang terlihat, yang tak mesti selalu berbentuk angka-angka atau koefisien antar variable. Berdasarkan masalah pada penelitian ini, bentuk penelitian yang sesuai adalah studi survey. Penelitian survey pada lumrahnya dilakukan untuk mencapai suatu generalisasi dari 
peninjauan yang tidak komprehensif (Sugiyono, 2011). Kerlinger dalam Sugiyono (2011) mengungkapkan bahwa penelitian survey bisa dilakukan pada komunitas kecil maupun besar, tetapi data yang dipelajari adalah data dari sampel yang diambil dari populasi tersebut. Subjek dalam penelitian ini adalah semua siswa kelas IX B SMP Negeri 4 Jawai yang telah mempelajari materi Aljabar. Alat penghimpunan data pada penelitian ini adalah verifikasi kemampuan menyelesaikan soal PISA, dan wawancara. Tahapan penelitian ini terdiri dari tiga tahapan yang dipaparkan sebagai berikut.

Tahap Persiapan

Tahapan yang dilaksanakan dalam tahap ini yaitu: (1) Melangsungkan observasi di SMP Negeri 4 Jawai; (2) Mengurus surat permohonan izin penelitian kepada ketua Prodi Pendidikan Matematika FKIP Untan; (3) Menyusun dan melakukan perbaikan proposal penelitian sesuai hasil seminar; (4) Menyusun instrument berupa enam buah soal tes tertulis; (5) Melakukan validasi instrument. Instrument yang di validasi adalah soal tes tertulis dan pedoman wawancara; (6) Merevisi soal yang sudah divalidasi baik isi maupun bahasa yang digunakan jika itu diperlukan; (7) Melaksnakan uji coba soal ke sekolah yang lain; (8) Memproses data hasil uji coba instrument.

Tahap Pelaksanaan

Tahapan yang dilakukan pada tahap ini yaitu: (1) Menentukan kelas yang akan menjadi subjek penelitian serta jadwal penelitian yang akan dilaksanakan; (2) Membagikan soal tes tertulis sebanyak 6 buah terkait kemampuan menyelesaikan soal PISA dengan konten change and relationship kepada subjek; (3) Mengoreksi hasil jawaban siswa sesuai dengan indikator yang telah ditetapkan; (4) Melakukan wawancara kepada subjek penelitian; (5) Mengklasifikasi seluruh data dari lapangan berupa tes tertulis dan transkip wawancara; (6) Menafsirkan dan membahas hasil analisis data; (7) Menarik kesimpulan dari dari hasil laporan; (8) Mengurus surat bukti telah melakukan penelitian pada tanggal 17 Oktober 2019 dari kepala SMP Negeri 4 Jawai.

Tahapan Akhir

Tahapan yang dilaksanakan pada tahap ini yaitu; Menggambarkan/mendeskripsikan hasil dari pengolahan data dan kemudian dianalisis data sebagai jawaban dari rumusan masalah yang diajukan dalam penelitian ini serta menyimpulkan hasil akhirnya; (2) Mengurutkan data hasil olahan ke dalam bentuk laporan penelitian.

\section{Hasil Penelitian dan Pembahasan}

\subsection{Hasil Penelitian}

Untuk memaparkan kemampuan menyelesaikan persoalan anak didik berdasar empat indikator, berpegang pada hasil penelitian yang telah dilaksanakan, sehingga didapatkanlah data yang dibutuhkan untuk menggapi rumusan masalah penelitian ini yakni merencanakan masalah, memahami soal tes, melangsungkan rencana penyelesaian dan mengoreksi kembali pada soal PISA konten change and relationship oleh anak didik SMPN4 Jawai. Pada bagian ini akan dijabarkan terkait hasil penelitian, 
pembahasan dan keterbatasan peneliti. Adapun tujuan dalam penelitian ini yakni untuk mendeskripsikan kemampuan menyelesaikan soal PISA pada konten change and relationship oleh siswa kelas IX B SMP N 4 Jawai. Sebanyak 26 anak didik kelas IX B SMP Negeri 4 Jawai menjadi subjek dalam penelitian ini yang telah mempelajari materi aljabar, dengan jumlah soal ada 6 soal essay. Tiap soal memiliki skor maksimal 16 dengan rentang skor 0 - 4 untuk tiap indicator menyelesaikan soal.

Tabel 1: Hasil Penskoran Kemampuan Menyelesaikan Soal PISA Konten Change and Relationship Siswa Kelas IX B SMP Negeri 4 Jawai Tahun Ajaran 2019/2020

\begin{tabular}{|c|c|c|c|c|c|c|c|c|}
\hline \multirow{2}{*}{ No. } & \multirow{2}{*}{ Nama } & \multicolumn{6}{|c|}{ Skor Tiap Soal } & \multirow{2}{*}{ Jumlah } \\
\hline & & 1 & 2 & 3 & 4 & 5 & 6 & \\
\hline & Jumlah Skor & 58 & 83 & 117 & 337 & 126 & 114 & 835 \\
\hline & Skor Maksimum & 416 & 416 & 416 & 416 & 416 & 416 & 2496 \\
\hline & Rata-rata Skor & 2.23 & 3.19 & 4.50 & 12.96 & 4.85 & 4.38 & 32.12 \\
\hline & Ketercapaian \% & 13.94 & 19.95 & 28.13 & 81.01 & 30.29 & 27.40 & 33.45 \\
\hline
\end{tabular}

Berdasarkan tabel 1. menggambarkan hasil tes kemampuan menyelesaikan persoalan PISA pada konten change and relationship siswa dengan persentase ketercapaian $33,45 \%$

\subsection{Pembahasan}

Dalam penelitian ini peneliti mempunyai 4 indikator soal PISA konten change and relationshiop yaitu mempersiapkan penyelesaian, memahami permasalahan, melakukan pemecahan, dan mengecek ulang. Sebanyak 6 soal dipakai pada penelitian ini. Dalam penelitian ini yang akan dibahas ialah kemampuan mengerjakan soal PISA konten change and relationship. (1) Memahami soal adalah satu diantara parameter kemampuan menyelesaikan soal metematika anak didik yang dibutuhkan saat menyelesaikan soal PISA. Tahap pada memahami soal antar lain membatasi informasi dari soal, menetapkan informasi penting, serta mengambil strategi yang tepat saat menyelesaikan soal. Dalam mengartikan informasi dalam masalah anak didik diharapkan bisa mengatakan informasi yang akan digunakan pada strategi penyelesaian. (2) Merencanakan menyelesaikan soal adalah tindakan dimana anak didik menimbang kembali informasi yang sangat penting dan menuliskan informasi apasaja yang terkait, mecari urutan atau pola pemecahan, dan memformulasikan berdasarkan pengetahuan yang sebelumnya anak didik dapat melalui tahapan pembelajaran. (3) Melaksanakan penyelesaian pada bagian penyelesaian ini adalah langkah dimana anak didik bisa menyelesaikan soal dan memperoleh jawaban yang tepat dan benar. (4) Memeriksa ulang. Tahap memeriksa ulang hasil adalah langkah akhir dari pendekatan kemampuan menyelesaikan soal matematis siswa. Hal tersebut perlu dilaksanakan saat ingin mengetahui hasil apa yang didapat telah tepat dengan syarat dan tidak timbul kesenjangan antara pertanyaan dengan jawaban.

Soal kemampuan menyelesaikan soal PISA terdiri dari enam soal essai dan dibagikan pada anak didik kelas IX. Peneliti tidak mengalami hambatan dan penelitian 
berlangsung sangat lancar karena pada saat membagikan soal kemampuan menyelesaikan soal PISA konten change and relationship pada anak didik kelas IX hadir semua. Eksemplar pengerjaan penyelesaian soal yang dibuat dalam penelitian ini berbentuk soal matematika PISA berbentuk soal cerita pada konten change and relationship atau pada materi aljabar. Hambatan yang dialami anak didik ialah karena mereka tidak benar-benar memahami materi yang ditanyakan pada setiap soal berdasar penunjuk menyelesaikan soal yang subjek penelitian alami berbeda partikularnya saat menyelesaikan soal cerita.

Jika dirincikan untuk soal nomor 1 terdapat 23 subjek yang mengerjakan soal seperti gambar 4.1 dan hanya ada 3 subjek yang menuliskan apasaja yang diketahui dan ditanyakan dan menyelesaikan soal dengan langkah penyelesaian yang benar dari soal tesebut. Dikaji dari jawaban subjek, bahwa mereka mengalami kesulitan saat memisalkan sisi dari persegi dan tidak mengingat rumus untuk mencari luas persegi dan keliling persegi. Walaupun rumus luas persegi benar, tapi rumus kelilingnya salah dan ini yang menyebabkan mereka keliru dalam menyelesaikan soal tersebut. Mereka juga tidak melakukan pemeriksaan kembali untuk memastikan jawaban mereka benar atau tidaknya dengan tidak menuliskan kesimpulan dalam jawaban mereka.

Untuk Soal nomor 2 terdapat terdapat 2 subjek yang mengerjakan seperti pada gamabar 4.2, ada 9 subjek menuliskan diketahui tapi tidak menuliskan apa yang ditanyakan dalam soal dan 15 subjek lainnya mengerjakan dengan cara yang sama yaitu langsung mengalikan nilai yang diketahui pada soal tanpa mengidentifikasi soal terlebih dahulu untuk mengetahui apa yang diperlukan untuk menjawab pertanyaan soal tersebut. Dapat dilihat dari jawaban subjek, bahwa 15 subjek yang lain tidak memahami soal sehingga langsung mengerjakan soal seperti mengalikan nilai yang ada pada soal dan tidak menuliskan apa yang ditanyakan dan diajwab, dan mereka juga tidak memeriksa kembali jawaban mereka untuk mengetahui kebenarannya dengan tidak menuliskan kesimpulan pada jawaban mereka.

Untuk soal nomor 3, terdapat 11 subjek mengerjakannya seperti pada gambar 4.3, ada 4 subjek mengerjakan mengerjakan sama hanya saja salah perhitungan, hal ini terjadi mungkin subjek kurang memperhatikan jawaban dan tidak melakukan pemeriksaan kembali terhadap soal ini, dan ada 11 subjek lainnya menjawab tidak cocok dengan apa yang terdapat pada soal. Ini dikarenakan siswa tidak memahami yang dimaksudkan pada soal tersebut, ialah apa diketahui dan ditanyakan pada soal tersebut sehingga mereka tidak bisa menyelesaikan masalah pada soal dan mereka juga tidak memeriksa kembali jawaban mereka dengan tidak menuliskan kesimpulan di jawaban mereka.

Pada soal nomor 4, terdapat 17 peseta didik mengerjakan dengan benar diantarananya ada 2 subjek mengerjakan seperti pada gambar 4.4, ada 15 subjek mengerjakan degan memisalkan untuk persegi enam nilainya 5 dan persegi nilainya 2 , jadi mereka mendapatkan untuk menara pertama memiliki tinggi $21 \mathrm{~m}$, menara kedua $19 \mathrm{~m}$ dan untuk menara ketiga yang dicari mereka mendapatkan tinggi $9 \mathrm{~m}$. karena mereka menambahkan tingi persegi enam dengan persegi sesuai banyak tingkatan yang 
ada pada gambar soal. Ada 2 subjek tidak menuliskan kesimpulan dari soal, dan ada 8 subjek yang mengerjakan dengan tidak menuliskan diketahi dan ditanya, ada yang salah dalam menghitung dan ada yang hanya menuliskan jawabannya saja, tidak menuliskan langkah pengerjaan dari soal tersebut dan tidak memeriksa kembali dengan menuliskan kesimpulan pada jawaban mereka. Dari penjelasan subjek sudah memahami soal, sehingga banyak subjek yang bisa menjawab soal ini.

Untuk soal nomor 5, terdapat 3 subjek mengerjakan seperti gambar 4.5 hanya saja satu subjek lainnya menegerjakan dengan menuliskan kesimpulan dari jawaban tersebut, dan 23 subjek lainnya mengerjakan dengan cara yang berbeda yaitu mereka menuliskan rumus yang diketahui pada soal hanya saja subjek tidak memahami mana yang harus dimasukkan untuk kerumus untuk menyelesaikan permasalah soal nomor 5. Pada lebar jawab, sebagian subjek menuliskanrumus yang ada pada soal dan menuliskan kesimpulan hanya saja jawaban yang dihasilkan dari penyelesaian soal ini belum tepat, subjek belum terlalu memahami permasalahan yang ada pada soal, dan tidak memeriksa kembali jawaban mereka dengan tidak menuliskan kesimpulan pada jawaban mereka.

Untuk soal terakhir yaitu soal nomor 6 terdapat 25 subjek yangmengerjakan hampir sama dengan gambar 4.6 dan hanya 1 subjek yang mengerjakan soal dengan jawaban yang hampir yang hampir benar. Pada soal ini, dari 25 subjek ada dari beberapa yang menuliskan diketahui hanya saja subjek tidak memahami soal dengan baik, ada yang menuliskan rumus yang akan digunakan, subjek juga menuliskan kesimpulan yang artinya mereka melakukan pemeriksaan kembali dari jawaban tersebut.

Berdasar pembahasan diatas bisa disimpul bahwa kemampuan menyelesaikan soal anak didik kelas IX B SMP Negeri 4 jawai masih dikatakan sangat rendah, karena masih banyak siswa yang belum medapat memenuhi kriteria menyelesaikan soal.

\section{Kesimpulan}

Berdasarkan hasil analisis data dan pembahasan yang telah dilakukan, diperoleh kesimpulan bahwa kemampuan menyelesaikan soal PISA konten change and relationship di SMP Negeri 4 Jawai masih sangat jauh tertinggal. Terlihat dari persentase rata-rata skor peserta didik yakni 33,45\%. Kemampuan anak didik pada saat menyelesaikan persoalan PISA konten change and relationship adalah sebagai berikut: (1) Anak didik tidak dapat memahami persoalan dengan tepat. (2) Anak didik tidak dapat mengenali dan memilih informasi yang relevan. (3) Anak didik tidak bisa menciptakan model matematika berdasarkan informasi yang ada dan membuat prediksi terhadap informasi yang relevan karena model matematika pada kondisi yang tersedia. (4) Anak didik kesukaran untuk menyatakan argument disetiap tahap menyelesaikan dan kesimpulan yang dibuat.

\section{Referensi}

Ahyan, S., dkk. 2014. Developing mathematics problems based on pisa level. IndoMS Journal Mathematics Education, 5(1), 47-56.

Hamidy, A. 2016. Kemampuan Siswa SMP Kalimantan Timur Dalam Menyelesaikan Soal Matematika Model PISA dan TIMSS. Proposal: Pascasarjana UNY. 
Vol 1 No 22020 Desember 2020

Jurnal AlphaEuclidEdu

Heppel, S., dkk. 2004. 21st century school: learning environments of the future. London: CABE \& RIBA.

Nasution, S. 2006. Metode Penelitian Naturalistik Kualitatif. Bandung: Tarsito

NCTM. 2000. Principles and Standards for School Mathematics. USA: the National Council of Teacher Mathematics inc.

OECD. 2013. PISA 2012 assessment and analytical framework: mathematics, reading, science, problem solving and financial literacy. Paris: OECD Publishing.

Pusztai, G dan Bacskai, K. 2015. Parochial schools and pisa effectiveness in three central european countries. Social Analysis, 5, 145-161.

Subana dan Sudrajat. 2011. Dasar-dasar Penelitian Ilmiah. Bandung: Pustaka Setia.

Sugiyono, 2011. Metode Penelitian Kuantitatif, Kualitatif dan R\&D. bandung: Alfabeta.

Suherman, Erman. 2001. Strategi Pembelajaran Matematika Kontemporer. Bandung: JICA-UPI

Wardhani, Sri. 2010. Pembelajaran Kemampuan Pemecahan Masalah Matematika di SMP. Yogyakarta: PPPPTK

Wijaya, A., Heuvel-Panhuizen, M. V., Doorman, M. et al. 2014. Difficulties in solving context-based PISA mathematics tasks: an analysis of students' errors. The Mathematics Enthusiast, 11, 555-584.

$\mathrm{Wu}, \mathrm{M} .2010$. Comparing the similarities and differences of PISA 2003 and TIMSS, OECD Education Working Papers, 32, OECD Publishing. http://dx.doi.org/10.1787/5km4psnm13nx-en 
Vol 1 No 22020 Desember 2020

Jurnal AlphaEuclidEdu

Received: 23/11/2020; Revised: 26/11/2020; Accepted: 03/12/2020

\title{
PENGUATAN KARAKTER SISWA PERBATASAN MELALUI INTERNALISASI KEARIFAN LOKAL DALAM PEMBELAJARAN MATEMATIKA
}

\author{
Yulis Jamiah \\ FKIP Universitas Tanjungpura Pontianak \\ yulis.jamiah@fkip.untan.ac.id
}

\begin{abstract}
This research is a study of developing the design of a mathematics learning model based on local wisdom to strengthen the character of junior high school students. Strengthening children's character by internalizing superior local wisdom values in terms of "intellectual development, Spiritual and emotional development, Physical and kinesthetic development, and Affective and Creativity development", in order to children with character can become children through learning mathematics. This goal is achieved in several stages. The first stage is exploring character values according to real conditions in the field. Its shown by using a qualitative approach is supported by written data although from interviews, documentation, observations, and questionnaires. The second stage is the stage of development, design, and testing in a limited scope. The research method used in this research is a development research method with a product trial component. Data collection techniques through observation and questionnaires. Qualitative and quantitative data analysis techniques are complementary. The value of local wisdom comes from cultural products and work cubes, which function as a medium in the learning process which is full of local wisdom values, which have not been used optimally by junior high school teachers. The implementation of the design of this mathematics learning model can train students 'thinking and reasoning in drawing conclusions, develop student creative activities that involve imagination, intuition, and discovery by developing divergent thinking, curiosity, making predictions, and developing students' ability to solve problems and convey information or ideas
\end{abstract}

Keywords: Mathematics Learning Model Design, Local Wisdom Value, Student Character

\section{PENDAHULUAN}

Penguatan karakter siswa melalui harmonisasi olah hati, olah rasa, olah pikir, dan olah raga yang melibatkan kerja sama antara satuan pendidikan, keluarga, dan masyarakat. Kegiatan penguatan karakterr tersebut sebagai bagian dari Gerakan Nasional Revolusi Mental. Proses kegiatannya merupakan gerakan pendidikan di bawah tanggung jawab satuan pendidikan (Perpres No. 87 Tahun 2017). Lebih lanjut Mendikbud (Muhadjir Effendy) mengamanahkan kepada para guru dan tenaga kependidikan untuk membekali penguatan karakter para siswa dimulai sejak tingkat sekolah dasar (SD) hingga sekolah menengah pertama (SMP). Penguatan karakter itu berguna bagi siswa terutama pada jenjang mereka pada berikutnya, sehingga siswa tersebut merupakan generasi yang tumbuh sebagai penerus bangsa jauh lebih handal, nasionalis dan kuat. Siswa yang memiliki karakter kuat mampu memelihara dan membangun Negara Kesatuan Republik Indonesia (TribunNews.com, 12-02-2018).

Masyarakat perbatasan terutama generasi usia sekolah mempunyai potensi kearifan lokal yang dapat dikembangkan, mempunyai nilai strategis berfungsi memelihara dan membangun di wilayah perbatasan, dapat memperkuat prilaku gotong royang atau rasa kebersamaan bangsa dan dapat membangun kepercayaan jati diri bangsa. Selain itu, masyarakat perbatasan terutama siswa-siswa sekolah SMP sebagai agen sosial yang berfungsi melestarikan nilai-nilai kearifan lokal. Sikap atau prilaku siswa tersebut sebagai modal sosial memupuk rasa kebersamaan sehingga tetap 
Vol 1 No 22020 Desember 2020

Jurnal AlphaEuclidEdu

Received: 23/11/2020; Revised: 26/11/2020; Accepted: 03/12/2020

mencintai dan mempertahankan bangsa dan negaranya.

Keberadaan kearifan lokal masyarakat perbatasan disatu sisi merupakan kekayaaan budaya masyarakat perbatasan, namun disisi lain jika ditelusuri menimbulkan suatu masalah yang menyangkut keaharmonisan hubungan kedua Negara, di antaranya ketika masyarakat perbatasan berada pada posisi sulit harus memilih antara semangat rasa kebersamaan tetap mencintai bangsa sendiri dengan kebutuhan ekonomi. Secara geografis, kedekatan akses masyarakat kedua negara lebih leluasa berinteraksi didukung pula secara historis hubungan sosial kedua lebih bersifat emosional diikat hubungan kekerabatan dan adat istiadat. Prilaku adat istiadat negara tetangga yang dominan muncul dan mudah terserap karena tidak adanya filter yang cukup kuat, serta kurang sesuai dengan budi pekerti luhur bangsa Indonesia ini, akan cepat masuk dan mudah ditiru oleh generasi muda.

Nilai-nilai leluhur bangsa Indonesia yang terkenal dan takkan pernah usang hingga kini, yakni: sopan santun, keramah-tamahan, kejujuran, dan menjunjung tinggi semangat kebersamaan atau"kegotong-royongan" serta sikap saling harga menghargai harkat dan martabat orang lain. Nilai-nilai tersebut merupakan warisan budaya dan karakter bangsa serta sebagai pembentuk peradaban bangsa Indonesia. Peradaban ini perlu terus dilestarikan dan dipelihara keberadaannya dalam kehidupan berbangsa dan bermasyarakat sehari-hari. Namun realitanya, dekadensi moral yang luar biasa telah menyebabkan keterpurukan bangsa Indonesia yang dulu dikenal sebagai bangsa santun dan taat beragama menjadi bangsa yang mengalami krisis nilai-nilai karakter bangsa, yang ditandai dengan semakin maraknya kejahatan dan tindakan-tindakan yang tidak mencerminkan nilai-nilai karakter bangsa.

Kenyataan yang mengarah pada penyimpangan nilai kebersamaan atau menggeser nilai gotong royong yang menjadi pilar utama budaya bangsa Indonesia. Oleh karena itu, perlu ada upaya yang mengarah pada penyadaran kembali terkait dengan rasa kebersamaan. Upaya yang dilakukan tidak terlepas dari lima potensi yang perlu dikembangkan melalui pendidikan, yakni: spriritual, emosional, intlektual, sosial, dan jasmani. Pengembangannya harus berdampak dalam pendidikan, yaitu menjadi masyarakat: 1) terpelajar; 2) terdidik; 3) sejahtera; 4) berbudaya; dan 5) beradab (Arif Rahman, 2015). Harapan dampak pendidikan dapat terwujud dengan baik, memerlukan pembelajaran tidak hanya berorientasi pada transfer of knowledge atau memindahkan pengetahuan saja melainkan juga harus berorientasi pada penguatan karakter siswa. Penguatan karakter siswa mutlak harus dilaksanakan sebagai upaya menghadapi ancaman era global. Salah satu upaya penguatan karakter dapat dilakukan melalui menginternalisasikan nilai-nilai kearifan lokal dalam pembelajaran matematika.

Pembelajaran matematika yang terintegrasi dengan kearifan lokal sangat tepat digunakan sebagai media untuk menguatkan karakter siswa di SMP Negeri 1 Perbatasan Jagoi Babang. Pengaktualisasian nilai-nilai kearifan lokal menggunakan produks budaya dan hasta karya daerah setempat. Pembelajaran matematika yang menempatkan siswa sebagai subyek untuk membangun pengetahuannya dengan memahami kondisi dalam lingkungan sekitarnya dapat membentuk nilai-nilai kemanusiaan pada diri siswa (Yulis, dkk, 2013: 50). Fenomena tersebut, adanya upaya untuk membentengi siswa dari sikap maupun prilaku yang sesuai dengan budaya Indonesia yaitu melalui penginternalisasian nilai-nilai kearifan lokal. Melalui pembentukan kepribadian yang 
Vol 1 No 22020 Desember 2020

Jurnal AlphaEuclidEdu

Received: 23/11/2020; Revised: 26/11/2020; Accepted: 03/12/2020

berpedoman pada nilai-nilai luhur, maka siswa sangat kuat untuk memelihara dan membangun Negara Kesatuan Republik Indonesia (NKRI). Salah satu media yang dapat digunakan untuk memberikan penguatan karakter dalam pembelajaran dengan menginternalisasikan nilai kearifan lokal.

Dari uraian tersebut, yang menjadi permasalahan dalam penelitian ini adalah: "Bagaimana menguatkan karakter melalui internalisasi nilai kearifan lokal dalam pembelajaran matematika di SMP Negeri 1 Jagoi Babang?" Untuk menjawab permasalahan tersebut, dirinci dalam beberapa pertanyaan penelitian: a) nilai kearifan lokal apa saja yang di imternalisasikan dalam pembelajaran matematika?; b) nilai-nilai karakter apa saja yang dikuatkan dalam pembelajaran matematika?; c) bagaimana penguatan karakter siswa melalui internalisasi nilai kearifan lokal?; d) bagaimana desain model pembelajaran matematika yang menguatkan karakter siswa melalui internalisasi nilai kearifan lokal?; e) bagaimana proses menguatkan karakter siswa melalui internalisasi nilai kearifan lokal dalam pembelajaran matematika?; f) bagaimana respon siswa dengan adanya penginternalisasian nilai kearifan lokal dalam pembelajaran matematika?; g) bagaimanakah tingkat keterterapan desain model pembelajaran yang dihasilkan?; dan h) bagaimanakah dampak desain model pembelajaran matematika yang dihasilkan untuk menguatkan karakter siswa melalui internalisasi nilai kearifan lokal.

Proses pembelajaran untuk membentuk prilaku siswa yang baik sangat dipengaruhi oleh kondisi kewibawaan dan kewiyataan yang ada pada diri guru selaku pendidik. Karena kondisi tersebut merupakan pilar pembelajaran. Kewibawaan dapat tercipta, jika guru mampu membangun sentuhan yang tinggi terhadap siswa sehingga terciptanya rasa aman dan nyaman bersama pendidiknya. Untuk mengkondisikannya dalam belajar ini, sangat perlu memperhatikan unsur-unsur kewibawaan, yaitu: 1) pengakuan dan penerimaan; 2) kasih sayang dan kelembutan; 3) penguatan; 4) tindakan tegas yang mendidik; dan 5) pengarahan dan keteladanan. Sementara unsurunsur yang ada pada kewiyataan, yaitu: 1) penguasaan materi pembelajaran; 2) penerapan metode pembelajaran; 3) penggunaan alat bantu pembelajaran; 4) pengembangan lingkungan pembelajaran; dan 5) penyelenggaraan penilaian pembelajaran (Phil Y.K., 2012: 110). Guru yang mencintai profesinya demi kemajuan siswa tidak akan merobohkan pilar pembelajaran. Selain itu, guru yang profesional tentu selalu mencerminkan prilaku yang dapat di tauladani oleh siswa, seperti berbahasa dengan bijak, baik dan benar, dengan bahasa yang indah-indah, serta dengan sopan santun akan menumbuhkan pikiran dan sikap positif, menumbuhkan keakraban dan mempererat persaudaraan, menumbuhkan simpati dan empati, menjauhkan lawan bicara dari rasa tertekan atau terintimidasi (Chairil, 2012: 9).

Pembelajaran matematika mempunyai tujuan, yakni membentuk kemampuan bernalar pada diri siswa yang tercermin melalui kemampuan berpikir kritis, logis, sistimatis dan memiliki sifat obyektif, jujur, disiplin dalam memecahkan suatu permasalahan baik dalam bidang matematika, bidang lain, maupun dalam kehidupan sehari-hari. Pembelajaran matematika dapat diartikan sebagai suatu upaya penataan lingkungan yang memberi nuansa agar program belajar matematika tumbuh dan berkembang secara optimal. Pmbelajaran matematika secara sempit, yaitu proses pembelajaran dalam lingkup persekolahan, sehingga terjadi proses sosialisasi individu siswa dengan lingkungannya, seperti guru, sumber atau fasilitas, dan teman 
Vol 1 No 22020 Desember 2020

Jurnal AlphaEuclidEdu

Received: 23/11/2020; Revised: 26/11/2020; Accepted: 03/12/2020

sesama siswa. Pembelajaran matematika humanis merupakan sebuah upaya yang memberikan dukungan bagi pengembangan kemampuan setiap individu secara holistik melalui perhatian terhadap mental, spiritual, etika, estetika, emosi, fisik dan pertumbuhan sosial, serta pengembangan scientific thinking, critical reasoning, problem solving skills, dan communication skill (Junaedi \& Asikin, 2012:116).

Menurut NCTM (2000:11), terdapat enam prinsip untuk mengatasi belajar matematika sekolah, yakni: 1) ekuitas, keunggulan dalam pendidikan matematika membutuhkan ekuitas, harapan yang tinggi dan dukungan yang kuat bagi semua siswa; 2) kurikulum, kurikulum dimaksudkan lebih dari sekumpulan kegiatan: hal itu harus koheren, terfokus pada matematika yang dianggap penting, dan diartikulasikan secara baik melalui penilaian; 3) pengajaran, pengajaran matematika yang efektif membutuhkan pemahaman terhadap apa yang siswa ketahui dan siswa perlukan untuk belajar dan kemudian tantangan serta dorongan untuk belajar secara baik; 4) belajar, siswa harus belajar matematika dengan pemahaman, secara aktif membangun pengetahuan baru dari pengalaman dan pengetahuan sebelumnya, 5) assessment, assessment atau penilaian harus mendukung pembelajaran matematika yang dianggap penting dan memberikan informasi yang berguna bagi guru dan siswa, 6) teknologi, teknologi sangat penting dalam proses belajar mengajar matematika, hal ini mempengaruhi matematika yang diajarkan dan meningkatkan proses belajar siswa.

Selain prinsip untuk mengatasi belajar matematika, ada yang perlu mendapatkan perhatian juga yaitu pendidikan karakter yang merupakan usaha sadar dan terencana dalam menanamkan nilai-nilai sehingga terinternalisasi dalam diri peserta didik yang mendorong dan terwujud dalam sikap dan perilaku yang baik. Pendidikan karakter bukan sekedar mengajarkan mana yang benar dan mana yang salah, pendidikan karakter juga menanamkan kebiasaan tentang hal yang baik sehingga mereka menjadi paham (domain kognitif) mana yang baik dan tidak, mampu merasakan (domain afektif) nilai yang baik, dan terbiasa melakukannya (domain perilaku). Jadi pendidikan karakter terkait erat dengan "habit" atau kebiasaan yang terus menerus dipraktekan atau dilakukan (Dirjendiknas, 2010:10).

Pembentukan dasar karakter siswa yang kuat melalui dua hal yang mengawalnya, yakni pola asuh orang tua di rumah dan budaya di sekolah dan masyarakat. Budaya sekolah dan masyarakat yang beradab membekali rasa malu untuk melakukan perilaku yang menyimpang dari norma agama pada diri siswa. Penanaman karakter melalui pola asuh dan budaya inilah yang menyebabkan siswa menjadi manusia yang beradab, untuk menjadi manusia yang beradab berarti memiliki kemampuan untuk memelihara dan mengembangkan pemahamannya terhadap nilai yang dianut di masyarakat (Arif Rahman, 2015: 11). Pembentukan dasar karakter siswa tidak dapat dilepaskan dari soal-soal penanaman nilai-nilai (transfer of value). Pembelajaran matematika merupakan kegiatan yang menggunakan fungsi dan nilai matematika sebagai alat untuk mencapai tujuan yang ditetapkan. Dalam melakukan proses pembelajaran matematika, pendidik berupaya meningkatkan atau selalu menumbuhkan sikap siswa yang selalu mengapresiasi nilai yang tersirat dalam matemateka. Pada hakekatnya, matematika itu sarat dengan nilai-nilai, seperti: nilai kejujuran, cermat, ketelitian, konsitensi, ulet, tekun, percaya diri, kerja keras dan tanggungjawab. Melalui pemahaman nilai-nilai tersebut diharapkan siswa dapat tumbuh 
Vol 1 No 22020 Desember 2020

Jurnal AlphaEuclidEdu

Received: 23/11/2020; Revised: 26/11/2020; Accepted: 03/12/2020

kesadaran dan kemauan untuk mempraktekkan segala sesuatu yang dipelajarinya. Dengan pembelajaran matematika, diharapkan siswa dapat mempelajari proses berpikir ilmiah terhadap kerangka konseptual dan struktur matematika dalam kehidupan seharihari.

Nilai-nilai luhur yang terkandung dalam kekayaan-kekayaan budaya lokal berupa tradisi, petatah-petitih dan semboyan hidup. Kearifan lokal dapat berupa pengetahuan lokal, keterampilan lokal, kecerdasan lokal, sumber daya lokal, proses sosial lokal, norma-etika lokal, dan adat-istiadat lokal (Robert Sibarani, 2013). Kearifan lokal merupakan pengetahuan yang dikembangkan oleh para leluhur dalam mensiasati lingkungan hidup sekitar mereka, menjadikan pengetahuan itu sebagai bagian dari budaya dan memperkenalkan serta meneruskan itu dari generasi ke generasi. Kearifan lokal terbentuk sebagai keunggulan budaya masyarakat setempat maupun kondisi geografis dalam arti luas. Kearifan lokal merupakan produk budaya masa lalu yang patut secara terus-menerus dijadikan pegangan hidup. Meskipun bernilai lokal tetapi nilai yang terkandung di dalamnya dianggap sangat universal (Sartini, 2004). Mengapa nilai kearifan lokal untuk basis dalam pembelajaran matematika? Salah satu alasannya, karena kearifan lokal di daerah akan mampu mengantarkan siswa untuk mencintai produk budaya daerahnya. Kecintaan siswa pada daerahnya akan mewujudkan ketahanan daerah. Ketahanan daerah merupakan kemampuan suatu daerah yang ditunjukkan oleh kemampuan warganya untuk menata diri sesuai dengan konsep yang diyakini kebenarannya dengan jiwa yang tangguh, semangat yang tinggi, serta dengan cara memanfaatkan alam secara bijaksana.

\section{METODE PENELITIAN}

Penelitian ini dilaksanakan dalam tiga tahap, yaitu: 1) memaparkan kondisi nyata di lapangan yang berkaitan dengan penguatan nilai karakter melalui internalisasi nilainilai kearifan lokal pada pembelajaran matematika; 2) pengembangan desain model pembelajaran matematika untuk menguatkan nilai karakter melalui internalisasi nilainilai kearifan lokal; dan 3) Validasi, yakni melalui uji coba secara luas dan memfinalkan desain model. Rincian dalam tiap tahap, diuraikan berikut ini.

1) Tahap Pertama

Metode yang digunakan adalah metode penelitian kualitatif. Penelitian ini bertumpu pada suatu fokus masalah. Menurut Moleong (2007: 93) masalah merupakan suatu keadaan yang bersumber dari hubungan antara dua faktor atau lebih yang menghasilkan situasi yang menimbulkan tanda tanya dan dengan sendirinya memerlukan upaya untuk mencari suatu jawaban. Dalam penelitian ini yang menjadi fokus penelitian adalah: 1) nilai-nilai karakter yang ditanamkan dalam pendidikan karakter di SMP Negeri 1 Jagoi Babang; 2) menginternalisasikan nilai-nilai kearifan lokal melalui pembelajaran matematika; dan 3) penguatan nilai karakter melalui kearifan local.

Penelitian dilaksanakan di Jagoi Babang Kabupaten Bengkayang. Dengan subyeknya siswa kelas VII SMP Negeri 1 Jagoi Babang. Penelitian ini lebih bersifat memaparkan kondisi nyata di lapangan yang berkaitan dengan penguatan nilai karakter melalui internalisasi nilai-nilai kearifan lokal dalam pembelajaran matematika. Penelitian dengan pendekatan kualitatif didukung oleh data dari angket maupun data 
Vol 1 No 22020 Desember 2020

Jurnal AlphaEuclidEdu

Received: 23/11/2020; Revised: 26/11/2020; Accepted: 03/12/2020

hasil wawancara. Penelitian ini diharapkan mampu memberikan gambaran mengenai penguatan nilai karakter melalui internalisasi nilai-nilai kearifan lokal dalam pembelajaran matematika.

Penjaringan dan pengumpulan data dilakukan dengan berbagai cara, yaitu: wawancara, dokumentasi, observasi, dan angket. Sedangkan teknik analisis data dilakukan secara terus-menerus sepanjang penelitian berlangsung dari awal sampai akhir, yaitu mulai dari tahap orientasi sampai pada tahap berakhirnya seluruh program tindakan sesuai dengan karakteristik pokok permasalahan dan tujuan penelitian. Analisis data adalah proses mencari dan menyusun secara sistematis data yang diperoleh dari hasil wawancara, catatan lapangan, dan dokumentasi, dengan cara mengorganisasikan data ke dalam katagori, menjabarkan ke dalam unit-unit, melakukan sintesa, menyusun ke dalam pola, memilih mana yang penting dan mana yang akan dipelajari, dan membuat kesimpulan sehingga mudah dipahami oleh peneliti maupun orang lain (Sugiyono, 2008:89)

Milles and Haberman (Sugiyono, 2008:91) mengemukakan bahwa aktivitas dalam analisis data kualitatif dilakukan secara interaktif dan berlangsung secara terus menerus sampai tuntas, sehingga datanya sudah jenuh. Aktivitas dalam analisis data, meliputi: 1) data reduction (reduksi data); 2) display data (pajangan data); dan 3) conclusion drawing/verification (kesimpulan dan verifikasi data).

2) Tahap Kedua

Penelitian tahap kedua ini berupa suatu pengembangan desain model pembelajaran matematika untuk menguatkan nilai karakter melalui internalisasi nilainilai kearifan lokal bagi siswa SMP. Pendekatan penelitian yang digunakan adalah Developmental Research (Borg \& Gall, 1989: 781-802) berupa siklus yang diawali dengan pengembangan desain model pembelajaran secara konseptual dan dilanjutkan dengan tahapan implementasi. Penjaringan dan pengumpulan data dilakukan dengan berbagai cara, baik tes dan non tes melalui: tes verbal (peragaan) siswa, dokumentasi, observasi, dan wawancara. Sedangkan teknik analisis data yang digunakan dilakukan secara kualitatif dan kuantitatif untuk saling melengkapi.

Penelitian ini dilaksanakan dalam tahapan, yaitu: tahap pengembangan, perancangan, dan uji coba dalam lingkup terbatas. Rincian dalam tiap tahap, diuraikan dalam langkah-langkah sebagai berikut:

a) Mengidentifikasi permasalahan di lapangan berdasar hasil penelitian tahap pertama.

b) Mengkaji permasalahan yang ditemukan pada langkah bagian a dan meninjaunya dari aspek perkembangan kognitif siswa dan permanfaatan pembelajaran matematika;

c) Mengembangkan desain model pembelajaran dengan penginternalisasikan nilai-nilai kearifan lokal untuk menguatkan karakter siswa;

d) Memvalidasi desain model pembelajaran dengan penginternalisasian nilainilai kearifan lokal untuk mendapat masukan dari para ahli, pengguna dan yang lainnya;

e) Menerapkan atau uji coba terbatas dalam bentuk penelitian tindakan dengan tindakan nyata pada mata pelajaran matematika. Sebelum uji coba, dilakukan 
Vol 1 No 22020 Desember 2020

Jurnal AlphaEuclidEdu

Received: 23/11/2020; Revised: 26/11/2020; Accepted: 03/12/2020

pelatihan pada guru pelaksana untuk memahami desain model pembelajaran yang telah dihasilkan.

f) Melakukan evaluasi dan perbaikan desain model pembelajaran matematika dengan penginternalisasian nilai-nilai kearifan lokal untuk menguatkan karakter siswa yang didasarkan langkah bagian e,

3) Tahap Ketiga

Tahap ini merupakan tahap validasi berupa eksperimentasi yang lebih luas. Langkah-langkah yang dilakukan di antaranya:

a) Melaksanakan uji coba yang lebih luas dalam bentuk penelitian tindakan kelas dengan tindakan nyata pada beberapa kelas dalam satu sekolah. Sebelum uji coba, dilakukan pelatihan pada guru pelaksana untuk memahami desain model pembelajaran yang telah dihasilkan.

b) Melakukan evaluasi dan perbaikan model pembelajaran matematika dari langkah bagian a dan menyeminarkannya bersama pelaksana (guru SMP) dan para ahli (dosen-dosen) sehingga diperoleh suatu desain model pembelajaran yang sesuai harapan;

c) Mengungkap keefektifan dan kelemahan penerapan desain model pembelajaran matematika yang dihasilkan dan membandingkannya dengan model pembelajaran yang lazim digunakan;

d) Menetapkan desain model pembelajaran matematika yang dihasilkan sebagai model akhir yang dapat disarankan kepada Sekolah SMP Negeri 1 Jagoi Babang. Nilai efektifitas hasil pengembangan penelitian ini berupa produk kreatif yaitu terbentuknya desain model pembelajaran matematika, yakni pembelajaran yang menciptakan suasana belajar efektif dan menyenangkan, mengedepankan nilai kearifan lokal untuk menguatkan karakter siswa, serta mengoptimalkan pengembangan kognitif yaitu kemampuan: pemecahan masalah, berfikir logis, dan berfikir secara kritis.

\section{HASIL PENELITIAN DAN PEMBAHASAN}

\section{a. Hasil Penelitian}

Berdasarkan pertanyaan-pertanyaan yang diajukan dalam masalah penelitian diperoleh hasil penelitian untuk menjawab beberapa pertanyaaan tersebut sebagai berikut:

1) Beberapa nilai-nilai yang diaplikasikan melalui aktivitas dan kebiasaan di sekolah ternyata sudah sesuai dengan yang nilai-nilai dalam pendidikan karakter yang tertuang pada Permendiknas No. 2 Tahun 2010. Namun, nilai-nilai yang sudah ditetapkan oleh pemerintah melalui pusat kurikulum tersebut tidak menjadi satu-satunya acuan nilai yang ditanamkan kepada peserta didik di dalam pendidikan karakter di SMP Negeri 1 Jagoi Babang. Nilai-nilai karakter yang ditanamkan disesuaikan dengan kebutuhan dan konteks di wilayah perbatasanan. Nilai-nilai karakter tersebut ditanamkan melalui serangkaian kegiatan dan sarana prasarana yang dimiliki oleh sekolah. Terdapat delapan nilai-nilai karakter yang sudah diterapkan secara rutin setiap hari selama lima hari belajar dalam seminggu pelaksaanan pembelajaran di sekolah SMP Negeri 1 Jagoi Babang. Penanaman nilai-nilai secara rutin melalui pembiasaan, tentu dengan maksud agar nilai nilai 
Vol 1 No 22020 Desember 2020

Jurnal AlphaEuclidEdu

Received: 23/11/2020; Revised: 26/11/2020; Accepted: 03/12/2020

tersebut terinternalisasi dan terpolarisasi kejiwa atau kesanubari siswa. Nilai-nilai karakter yang diaktualisasikan dan dinternalisasikan dalam pembelajaran matematika sehingga menguatkan karakter siswa adalah nilai-nilai seperti: jujur, disiplin, bertanggung jawab, ulet/pantang menyerah, sabar, dan tabah. Hal ini seperti pandangan Lickona (1991:51), karakter terbentuk melalui proses knowing the good, feeling the good, acting the good. Pandangan ini memberi arti bahwa pembentukan dan pengembangan karakter melalui proses pemahaman nilai-nilai karakter, menghayati atau meyakini nilai-nilai karakter, dan mewujudkan nilai karakter dalam perbuatan/tindakan.

2) Pada hasil survey data dasar diperoleh data yang berkaitan dengan nilai kearifan lokal, yakni nilai dan norma budaya yang berlaku dalam kehidupan masyarakat. Nilai dan norma yang diyakini kebenarannya menjadi acuan perilaku masyarakat setempat. Proses mengakomodasi nilai kearifan lokal meguatkan nilai karakter dalam pembelajaran matematika mencakup proses: a) mengkaji konsep matematika yang akan di ajarkan, misalkan konsep bidang datar (segitiga, segiempat, lingkaran, trapesium, atau kesimetrian); b) mengkaji media yang sesuai untuk mengajarkan konsep bidang datar yang dipilih tersebut, media yang digunakan seperti: Perisai atau Telawang; c) mengkaji nilai-nilai yang terkadung dalam media yang digunakan.

3) Dalam mengeksplorasi nilai kearifan lokal diperoleh data yang berkaitan dengan nilai kearifan lokal yang berlaku dalam kehidupan masyarakat dan nilai tersebut berkaitan dengan materi yang termuat dalam kurikulum SMP, khususnya mata pelajaran matematika. Hasil kajian keterkaitan antara nilai kearifan lokal dan konsep matematika tertuang pada tabel berikut ini.

Tabel 1. Kajian Nilai Kearifan Lokal Dalam Pembelajaran Matematika di SMP

\begin{tabular}{|c|c|c|c|}
\hline No & $\begin{array}{l}\text { Produk } \\
\text { Budaya }\end{array}$ & Nilai Kearifan lokal & $\begin{array}{c}\text { Konsep } \\
\text { Matematika }\end{array}$ \\
\hline 1 & $\begin{array}{l}\text { Perisai } \\
\text { atau } \\
\text { Talawang }\end{array}$ & $\begin{array}{l}\text { Bentuk Perisai melambangkan kekuatan } \\
\text { dan keteguhan seluruh komponen } \\
\text { masyarakat yang siap menghadapi } \\
\text { berbagai bentuk rintangan serta teguh } \\
\text { dalam memperjuangkan kejayaan dan } \\
\text { kemakmuran. Perisai berfungsi sebagai } \\
\text { pelengkap alat pertahanan diri ketika } \\
\text { berperang, dan sebagai pelengkap dalam } \\
\text { tari-tarian. Konon. Ukirannya memiliki } \\
\text { daya magis yang mampu membang-kitkan } \\
\text { semangat hingga menjadikan kuat orang } \\
\text { yang menyandangnya. Telawang sebagai } \\
\text { pelengkap mandau juga dianggap benda } \\
\text { sakti yang bisa memberikan kekuatan } \\
\text { pada pemiliknya. Talawang merupakan } \\
\text { benda budaya yang lahir dari kepercayaan } \\
\text { masyarakat Dayak terhadap kekuatan } \\
\text { magis. Talawang mengandung makna }\end{array}$ & $\begin{array}{l}\text { Pemahaman } \\
\text { konsep } \\
\text { segitiga, } \\
\text { segiempat, } \\
\text { segi enam, } \\
\text { dan } \\
\text { kesimetrian }\end{array}$ \\
\hline
\end{tabular}


Vol 1 No 22020 Desember 2020

Jurnal AlphaEuclidEdu

Received: 23/11/2020; Revised: 26/11/2020; Accepted: 03/12/2020

\begin{tabular}{|c|c|c|}
\hline & $\begin{array}{l}\text { simbolis yakni lambang kekuatan dan } \\
\text { pertahanan. Selain itu mengandung makna } \\
\text { akan kesatria dan kewibawaan, bagi } \\
\text { pemilik talawang yang dipadukan dengan } \\
\text { mandau menunjukkan pemiliknya tersebut } \\
\text { orang yang pemberani dan kuat. }\end{array}$ & \\
\hline $\begin{array}{l}\text { Rumah adat } \\
\text { Pangah }\end{array}$ & $\begin{array}{l}\text { Rumah adat menggambarkan suatu yang } \\
\text { sakral atau suci tempat bersemayamnya } \\
\text { Jubata (Tuhan), dan menyimbolkan } \\
\text { adanya rasa cinta dan penghormatan } \\
\text { terhadap leluhur (nenek moyang). } \\
\text { Bangunan rumah adat mempunyai tiang } \\
\text { berjumlah } 9 \text { tiang yang bermakna smbolik } \\
\text { angka } 9 \text { bahwa pada angka } 9 \text { dianggap } \\
\text { angka tertinggi yang mempunyai nilai } \\
\text { keberuntungan bagi warga desa. Rumah } \\
\text { adat mempunyai fungsi sebagai wadah } \\
\text { mempersatukan warga dalam memuja } \\
\text { kepada roh-roh nenek moyang }\end{array}$ & $\begin{array}{l}\text { Pemahaman } \\
\text { konsep } \\
\text { segitiga, } \\
\text { segiempat, } \\
\text { lingkaran, } \\
\text { deameter, } \\
\text { jari-jari, } \\
\text { keliling } \\
\text { lingkaran,d } \\
\text { an luas } \\
\text { lingkaran } \\
\text { dan } \\
\text { kesimetrian, }\end{array}$ \\
\hline $\begin{array}{l}\text { Rumah } \\
\text { Betang atau } \\
\text { Radankg } \\
\text { atau Boli } \\
\text { Omu }\end{array}$ & $\begin{array}{l}\text { Rumah Betang terdiri dari } 20 \text { sampai } 40 \\
\text { lawang/pintu, dengan satu tangga untuk } \\
\text { turun naik, dapat diutup dan dinaikan } \\
\text { keatas untuk menjaga keamanan. Rumah } \\
\text { panjang dibangun dengan tiang tinggi } \\
\text { untuk menghindari serangan binatang } \\
\text { buas atau musuh. Rumah Betang menjadi } \\
\text { simbol yang kukuh dari kehidupan } \\
\text { komunal bagi masyarakat Dayak tidak } \\
\text { saja sekadar ungkapan legendaris } \\
\text { kehidupan nenek moyang, melainkan juga } \\
\text { suatu pernyataan secara utuh dan konkret } \\
\text { tentang tata pamong desa, organisasi } \\
\text { sosial serta sistem kemasyarakatan, } \\
\text { menjadi titik sentral kehidupan warganya. } \\
\text { Sistem nilai budaya yang dihasilkan dari } \\
\text { proses kehidupan rumah panjang, } \\
\text { menyangkut soal makna dari hidup } \\
\text { manusia; makna dari pekerjaan; karya dan } \\
\text { amal perbuatan; persepsi mengenai waktu; } \\
\text { hubungan manusia dengan alam sekitar; } \\
\text { soal hubungan dengan sesama. Rumah } \\
\text { betang adalah pusat kebudayaan mereka } \\
\text { karena disanalah seluruh kegiatan dan } \\
\text { segala proses kehidupan berjalan dari } \\
\text { waltu ka waltu Meraka mannintai }\end{array}$ & $\begin{array}{l}\text { Pemahaman } \\
\text { konsep } \\
\text { segitiga, } \\
\text { segiempat, } \\
\text { lingkaran, } \\
\text { deameter, } \\
\text { jari-jari, } \\
\text { keliling } \\
\text { segitiga, } \\
\text { keliling } \\
\text { segi empat, } \\
\text { luas } \\
\text { segitiga, } \\
\text { loas segi } \\
\text { empat dan } \\
\text { kesimetrian, }\end{array}$ \\
\hline
\end{tabular}


Vol 1 No 22020 Desember 2020

Jurnal AlphaEuclidEdu

Received: 23/11/2020; Revised: 26/11/2020; Accepted: 03/12/2020

4) Dalam pemantauan pelaksanaan pembelajaran matematika di SMP diperoleh data yang berkaitan dengan permasalahan pembelajaran matematika, seperti kesenjangan antara model pembelajaran dengan penerapannya, atau kurikulum dan model pembelajaran matematika yang sedang digunakan. Pada Kurikulum Tahun 2013 diakomodasi kompetensi secara komprehensif, yaitu pendidikan harus menghasilkan lulusan yang berkompeten pada aspek sikap, aspek pengetahuan, dan aspek keterampilan, sehingga dapat membantu mempersiapkan anak beradaptasi secara kreatif dengan lingkungan masa kini dan masa depan kehidupannya.

5) Berkaitan dengan pertanyaan tentang apakah pembelajaran matematika yang dilaksanakan saat ini telah mencerminkan adanya nilai-nilai karakter, diperoleh informasi bahwa guru pada umumnya beranggapan pembelajaran matematika belum mencerminkan atau memuat nilai-nilai karakter, tetapi pembelajaran matematika diaplikasikan dalam kehidupan sehari-hari. Dalam pembelajaran matematika diajarkan ketelitian, kecermatan, kejujuran, dan keterampilan memecahkan masalah, dan pada Kurikulkum 2013 sudah tercermin nilai-nilai karakter dengan kegiatan diskusi kelompok seperti adanya nilai disiplin. Tidak semua guru dan sekolah saat ini melaksanakan pembelajaran matematika yang mencerminkan adanya nilai karakter, dan masih terlihat guru melaksanakan pembelajaran matematika secara konvensional.

6) Berkaitan dengan pertanyaan tentang apakah pembelajaran matematika yang dilaksanakan saat ini telah memanfaatkan media hasil karya masyarakat atau daerah setempat sebagai sumber belajar, diperoleh informasi bahwa responden pada umumnya menyatakan sampai saat ini masih belum pernah memanfaatkan media hasil karya masyarakat setempat sebagai sumber belajar dalam pembelajaran matematika, dan sebagian kecil responden menyatakan ada salah satu media pembelajaran yang diaplikasikan dalam hasil karya masyarakat misalnya perisai untuk berperang. Namun pertanyaan ini menginspirasi guru untuk memikirkan karya apa di masyarakat yang lebih inovatif bisa menunjang pembelajaran.

7) Dari hasil angket pada guru matematika berkaitan dengan faktor yang mempengaruhi kemauan guru dalam mengajarkan matematika berbasis nilai kearifan lokal di SMP diperoleh informasi antara lain: adanya keinginan siswa untuk mengenal budayanya sendiri, adanya kreativitas guru, keinginan untuk menciptakan proses pembelajaran menjadi lebih menyenangkan, keinginan untuk memotivasi diri dalam pembelajaran, ketersediaan media di daerah setempat yang berbasis kearifan lokal dan nilai karakter.

8) Berdasarkan hasil angket tentang tentang respon guru terhadap proses pembelajaran matematika diperoleh informasi bahwa seluruh responden setuju jika penyajian matematika melalui pembelajaraan yang menyenangkan, dan penggunaan media dari daerah setempat dalam pembelajaran matematika menunjukkan guru ikut melestarikan keberadaan nilai-nilai lokal dari media tersebut. Beberapa saran yang diajukan guru sehubungan dengan pelaksanaan pembelajaran matematika agar tertata lebih baik antara lain: (i) sebaiknya pembelajaran matematika dibuat dengan menarik sehingga dapat menciptakan 
Vol 1 No 22020 Desember 2020

Jurnal AlphaEuclidEdu

Received: 23/11/2020; Revised: 26/11/2020; Accepted: 03/12/2020

keaktifan dan kreativitas siswa, (ii) perlu adanya pembinaan dari pihak yang lebih menguasai dan memahami serta perlu adanya kerja sama, (iii) guru harus mampu menguasai materi dan bisa memanfaatkan media pembelajaran disekitar agar pelajaran tersebut menyenangkan dan tidak membosankan, (iv) guru harus lebih kreatif dan inofatif dalam melaksanakan pembelajaran matematika, (v) guru harus lebih kreatif dalam membuat setting pembelajaran dan menggunakan RPP yang baik sebagai panduan mengajar, dan (vi) guru harus meningkatkan kompetensinya melalui pengembangan kreativitasnya.

9) Dengan tuntutan kewibawaan dan kewiyataan yang ada pada diri guru berdasarkan informasi di atas, maka perlu disusun desain model pembelajaran yang mencirikan dua hal tuntutan tersebut. Desain model pembelajaran matematika dengan menginternalisaikan nilai kearifan lokal sangat diperlukan karena memberikan bekal pengetahuan, ketrampilan dan perilaku kepada peserta didik agar mereka memiliki wawasan yang mantap tentang keadaan lingkungan dan kebutuhan masyarakat sesuai dengan nilai-nilai/aturan yang berlaku di daerahnya dan mendukung pembangunan daerah serta pembangunan nasional. Desain model pembelajaran matematika yang dikembangkan ini sebagai modifikasi dari model pembelajaran kooperatif dengan mengacu kepada paradigma pembelajaran konstruktivisme. Model pembelajaran ini bertujuan untuk mengembangkan daya matematis siswa secara maksimal dan kemampuan berargumentasi dan berkomunikasi logis, serta mengembangkan kreativitas dan kemampuan berfikir tingkat tinggi. Adapun strategi yang dapat digunakan dalam model pembelajaran ini dapat dilakukan dengan langkah berikut:

a) Mendiskusikan materi yang tertuang dalam LKPD sebagai masalah kelompok. Mengorganisasi permasalahan penting dilakukan dengan berdiskusi dan harus diupayakan agar bermakna bagi setiap anggota kelompok. Masalahnya harus kontekstual, yaitu berkaitan dengan situasi kehidupan nyata bagi siswa, diusahakan memberi jawaban tidak dengan tebakan, dan mencari berbagai solusi yang rasional.

b) Melakukan penyelidikan secara cermat dan autentik. Hal ini dapat dimulai dengan proses saintifik, mulai dari pengamatan, pengajuan masalah, penalaran, percobaan, menganalisis, dan mengembangkan hipotesis, serta penyimpulan.

c) Presentasi hasil kerja kelompok. Mempresentasikan dan memperagakan berbagai hasil kerja, dapat berbentuk laporan pemecahan masalah, atau laporan hasil kegiatan.

d) Bekerjasama dalam kelompok. Memotivasi siswa untuk belajar dalam kelompok kerja kolaboratif yang terdiri dari $4-5$ orang siswa dalam memecahkan masalah yang diberikan. Hal ini bermanfaat untuk memberikan motivasi berkelanjutan pada saat terlibat dalam tugas-tugas yang lebih kompleks untuk pengembangan keterampilan sosial.

\section{b. Pembahasan}

Dari hasil pengamatan pada saat pelaksanaan ujicoba di sekolah di daerah Jagoi 
Vol 1 No 22020 Desember 2020

Jurnal AlphaEuclidEdu

Received: 23/11/2020; Revised: 26/11/2020; Accepted: 03/12/2020

Babang, teridentifikasi bahwa pelaksanaan model pembelajaran matematika berbasis nilai kearifan lokal tersebut dapat berjalan sesuai rencana yang tertuang dalam Rancangan Pelaksanaan Pembelajaran Matematika. Beberapa tahapan kegiatan yang masih belum dapat terlaksana secara maksimal di antaranya sebagai berikut:

1) Pada kegiatan pendahuluan ada tahapan yang belum jelas tersampaikan oleh guru, seperti penyampaian tujuan pembelajaran, pemberian motivasi yang berkaitan dengan kegiatan di masyarakat sehari-hari, dan tanya jawab seputar apersepsi yang belum optimal.

2) Pada kegiatan inti (pengembangan) ada tahapan yang tidak terlaksana, seperti pemberian motivasi bahwa siswa punya peluang menjadi orang sukses, tahap presentasi hasil kerja siswa dilakukan dimeja masing-masing kelompok,

3) Pada kegiatan penutup belum tersampaikan tahapan menugaskan siswa untuk mengembangkan kreativitasnya di rumah terkait pemahaman materi yang baru dipelajari.

Pembelajaran matematika secara manusiawi berkenaan dengan proses pembelajaran matematika yang menempatkan siswa sebagai subyek untuk membangun pengetahuannya dengan memahami kondisi-kondisi dalam diri sendiri maupun lingkungan sekitarnya. Model pembelajaran matematika ini akan membentuk nilai-nilai kemanusiaan dalam diri siswa. Dampak bagi para siswa dengan implementasi model pembelajaran dengan menginternalisaikan nilai kearifan lokal sesuai dengan pengembangan kurikulum di antaranya: melatih cara berpikir dan bernalar siswa dalam menarik kesimpulan, mengembangkan aktivitas kreatif siswa yang melibatkan imajinasi, intuisi, dan penemuan dengan mengembangkan pemikiran divergen, orisinil, rasa ingin tahu, dan membuat prediksi; mengembangkan kemampuan siswa dalam memecahkan masalah; dan mengembangkan kemampuan siswa dalam menyampaikan informasi atau gagasan.

Secara umum tahapan pembelajaran tersebut dapat dilaksanakan oleh guru model. Terlaksananya uji coba pembelajaran tersebut karena adanya berbagai faktor pendukung. Struktur pembelajaran yang diterapkan masih menggunakan struktur pembelajaran pada umumnya dengan tahapan kegiatan mulai dari tahap persiapan, tahap pendahuluan, tahap pengembangan, tahap penerapan, dan tahap penutup.

Berdasarkan hasil pengamatan dan diskusi dalam penelitian ini, pembelajaran matematika dengan menginternalisaikan nilai kearifan lokal memungkinkan untuk diterapkan. Hal ini dapat disebabkan karena struktur pembelajaran yang sama dengan pembelajaran pada umumnya, dan guru yang melaksanakan adalah sarjana pendidikan matematika yang juga sudah mengikuti pelatihan pengembangan pembelajaran termasuk pelatihan penerapan Kurikulum 2013. Guru yang bersangkutan juga merespon secara positif terhadap ujicoba penerapan pembelajaran tersebut.

Berkaitan dengan siswa yang terlibat dalam pelaksanaan uji coba desain model pembelajaran dalam penelitian ini, tampak siswa merespon secara positif setiap tahapan pembelajaran, baik berupa kegiatan diskusi, kegiatan tanya jawab antara guru dan siswa dan juga sesama teman, serta tahapan kegiatan lainnya. Aktivitas diskusi kelompok dalam pembelajaran menjadi kegiatan yang cukup 
Vol 1 No 22020 Desember 2020

Jurnal AlphaEuclidEdu

Received: 23/11/2020; Revised: 26/11/2020; Accepted: 03/12/2020

menyenangkan bagi siswa, karena mereka merasa lebih leluasa belajar dengan sesama teman dari pada hanya memperhatikan penjelasan guru.

\section{KESIMPULAN DAN SARAN}

\section{a. Kesimpulan}

Sasaran utama pembelajaran matematika adalah pengembangan kemampuan proses dalam pemecahan masalah. Untuk itu sajian desain model pembelajaran yang memungkinkan adalah diawali dengan menyajikan masalah yang memerlukan jawaban yang bervariasi dalam cara menyelesaikan atau hasil akhir. Beberapa kesimpulan yang dapat dipaparkan dalam penelitian ini adalah sebagai berikut:

1) Nilai-nilai karakter yang diaktualisasikan dan diinternalisasikan dalam pembelajaran matematika yang dapat menguatkan karakter peserta didik adalah nilai-nilai seperti: jujur, disiplin, bertanggung jawab, ulet/pantang menyerah, sabar, dan tabah. Untuk menguatkan karakter peserta didik melalui internalisasi nilai kearifan lokal dengan cara menceritakan satu diantara produk budaya Dayak Bidayuh, seperti cerita upacara/acara Gawia Sowak yang dilaksanakan oleh masyarakat Dayak Bidayuh setiap tanggal 3 Juni setiap tahunnya. Kandungan cerita memuat beberapa nilai karakter yang dikuatkan, seperti nilai religus, nilai toleransi, nilai disiplin, nilai kerja keras, nilai saling menghargai, nilai cinta damai, nilai peduli lingkungan, dan nilai tanggungjawab, serta nilai gotong royong.

2) Perlunya mengeksplorasi berbagai permasalahan pelaksanaan pembelajaran di sekolah khususnya di daerah perbatasan atau pedalaman. Permasalahan pembelajaran tersebut selanjutnya dikaitkan dengan nilai-nilai kearifan lokal yang sesuai dan berlaku di masyarakat, seperti bentuk perisai yang melambangkan kekuatan dan keteguhan komponen masyarakat yang siap menghadapi berbagai rintangan serta teguh dalam memperjuangkan kejayaan dan kemakmuran.

3) Pembelajaran matematika yang dilaksanakan saat ini belum banyak mencerminkan nilai karakter, dan masih ada sebagian guru melaksanakan pembelajaran matematika secara konvensional, karakter yang dimunculkan dalam pembelajaran matematika masih sulit untuk dicerna siswa. Selain itu guru belum pernah atau jarang memanfaatkan media hasil karya masyarakat sebagai sumber belajar dalam pembelajaran matematika.

4) Faktor yang mempengaruhi kemauan guru dalam mengajarkan matematika berbasis nilai kearifan lokal di SMP antara lain adanya keinginan agar siswa mengenal budayanya sendiri, munculnya kreativitas guru yang bersangkutan, keinginan menciptakan proses pembelajaran menjadi lebih menyenangkan, keinginan untuk memotivasi diri dalam pembelajaran, serta ketersediaan media di daerah setempat yang berbasis kearifan lokal dan nilai karakter.

5) Respon guru maupun siswa terhadap pelaksanaan pembelajaran matematika agar tertata lebih baik antara lain menyarankan pembelajaran matematika dibuat menarik sehingga dapat menciptakan keaktifan dan kreativitas siswa, adanya pembinaan dari pihak yang lebih menguasai dan perlunya kerja sama, guru harus mampu menguasai materi dan dapat memanfaatkan media di sekitar agar 
Vol 1 No 22020 Desember 2020

Jurnal AlphaEuclidEdu

Received: 23/11/2020; Revised: 26/11/2020; Accepted: 03/12/2020

pelajaran tidak membosankan, guru lebih kreatif dan inovatif dalam membuat setting pembelajaran dan melaksanakan pembelajaran.

6) Model pembelajaran matematika berbasis nilai kearifan lokal merupakan model yang mengacu pada aspek pembelajaran matematika secara manusiawi yang menempatkan siswa sebagai subyek untuk membangun pengetahuannya dengan memahami kondisi dalam diri sendiri maupun lingkungan sekitarnya, serta dapat membentuk nilai-nilai kemanusiaan pada diri siswa. Kreativitas guru diperlukan untuk memfasilitasi kegiatan belajar siswa dengan mengacu pada paradigma pembelajaran konstruktivisme. Penerapan model pembelajaran ini dapat melatih cara berpikir dan bernalar siswa dalam menarik kesimpulan, mengembangkan aktivitas kreatif siswa yang melibatkan imajinasi, intuisi, dan penemuan dengan mengembangkan pemikiran divergen, rasa ingin tahu, membuat prediksi, serta mengembangkan kemampuan siswa dalam memecahkan masalah dan menyampaikan informasi atau gagasan.

b. Saran

Berdasarkan hasil penelitian yang tersirat pada kesimpulan di atas dapat dikemukakan beberapa saran berikut ini.

1) Para praktisi pendidikan perlu menggali media atau budaya yang berkaitan dengan nilai-nilai kearifan lokal dan nilai karakter di masyarakat, agar dapat menjadi media dan sumber belajar yang dapat mengatasi permasalahan pendidikan di daerah.

2) Penelitian semacam ini dapat dilaksanakan bersinergi dengan pihak-pihak yang berkepentingan di lapangan, khususnya bagi pemegang kebijakan atau pemuka masyarakat di daerah setempat, sehingga kendala nonteknis yang terjadi tidak terlalu berpengaruh pada pelaksanaan penelitian.

3) Bagi dinas terkait perlu memberi rangsangan dan motivasi kepada para guru/pendidik agar berkeinginan untuk mengembangkan model-model pembelajaran yang lebih kreatif dengan memanfaatkan media dan hasil karya daerah setempat, agar proses pembelajaran menjadi lebih menyenangkan bagi siswa. 
Vol 1 No 22020 Desember 2020

Jurnal AlphaEuclidEdu

Received: 23/11/2020; Revised: 26/11/2020; Accepted: 03/12/2020

\section{REFERENSI}

Aif Rachman (2015). Guru Berdasarkan Catatan Ukim Komarudin, Penerbit Erlangga.

Borg, W.R. \& Gall, D. M. (1989). Educational Reasearch: Introduction. New York: Longman.

Chairif E. (2012) Peranan Bahasa Melayu dalam Membangun Karakter Bangsa, Bahan Seminar Nasional di Hotel Aston Pontianak Tgl 5-6 Juni 2012

Junaidi dan M. Asikin. (2012). Pengembangan pembelajaran Matematika Humanistik untuk Meningkatkan Kemahiran Matematis, Unnes Journal of Mafhematicts Educatioan Research. http://journal.unnes.ac.id/sju/index.php/ujmer. [on-line, diakses 10 Mei 2013].

Kemendiknas. (2010). Pembinaan Pendidikan Karakter di Sekolah Menengah Pertama, Jakarta

. (2011). Panduan Pelaksanaan Pendidikan Karakter, Badan Penelitian Dan Pengembangan Pusat Kurikulum Dan Perbukuan, Jakarta.

Lickona, T. (1991). Educating for Character: How Our Schools Can Teach Respect and Responsibility. New York: Simon \& Schuster, inc.

Moleong, Lexy. (2007). Metodologi Penelitian Kualitatif. Bandung: Rosdakarya

National Council of Teachers of Mathematics. (2000). Principles and standards for school mathematics. Reston, VA: NCTM.

Phil Yanuar Kiram. (2012). Profesi Pendidik Seutuhnya dalam Perseptif Penyiapan Manusia Indonesia Generasi 2045. Materi Konvensi Nasional Pendidikan Indonesia (KONASPI) VII 2012 di Yogyakarta Tgl 31 Oktober - 3 November 2012. Penerbit: UNY Press.

Robert Sibarani. (2013). The character building based on local wisdom. http://www.museum.pusaka-nias.org/2013/02/pembentukan-karakterberbasis-kearifan. html [on-line diunduh 29 April 2013 ].

Sartini. (2004). Menggali Kearifan Lokal Nusantara Sebuah Kajian Filsafati, Jurnal Filsafat, UGM, Edisi Bulan Agustus 2004, Jilid 37, Nomor 2

Sugiyono. (2008). Metode Penelitian Kuantitatif Kualitatif dan $R \& D$. Bandung: Albeta.

Yulis J., dkk (2013). Pengembangan Model Pembelajaran Matematika Humanis Sederhana Berbasis Pendidikan Karakter Bagi Mahapeserta didik Pendidikan Matematika FKIP Untan Pontianak. Laporan Penelitian.

\section{Internet:}

Ahmad S. (2010). Konsep Pendidikan Karakter. (http://akhmadsudrajat.wordpress.com., [On-line diunduh 23 Januari 2012]

Materi Perpres No. 87 Tahun 2017 tentang Penguatan Pendidikan Karakter 
Vol 1 No 22020 Desember 2020

Jurnal AlphaEuclidEdu

Received: 21/10/2020; Revised: 27/11/2020; Accepted: 03/12/2020

\title{
KEMAMPUAN KOMUNIKASI MATEMATIS SISWA DIKAJI DARI SELF CONFIDENCE
}

\author{
${ }^{\mathbf{1}}$ Putri, Tjut Aflianti Eka, ${ }^{\mathbf{2} J a m i a h, ~ Y u l i s, ~}{ }^{\mathbf{3}}$ Sayu, Silvia \\ 1,2,3Pendidikan Matematika FKIP Universitas Tanjungpura Pontianak
}

Email: tjutaflianti@gmail.com

\begin{abstract}
The purpose of this research is to describe the mathematical communication skills of students assessed from self confidence in the material system of two-variable linear equations in SMP Muhammadiyah 1 Pontianak. The method in this research is descriptive research method with survey research. The sample of the research were the students of IX A SMP Muhammadiyah 1 Pontianak. Research subjects were 28 students. From the results of the self confidence questionnaire, obtained data of 6 students having a low level of self confidence and 22 students having a high level of self confidence. In addition to administering questionnaires, students were also given mathematical communication skills test and interview questions. From the results of tests and interviews obtained written mathematical communication skills of subjects with low levels of self confidence can fulfill one of the four indicators of mathematical communication skills. While the verbal mathematical communication skills of subjects with low self confidence levels can fulfill two of the four indicators of mathematical communication skills. In addition, subjects with high levels of self confidence can fulfill all indicators of mathematical communication skills both in writing and verbal.

Keywords: Mathematical Communication, Self Confidence
\end{abstract}

\section{Pendahuluan}

Pemerintah tak henti-hentinya berupaya dalm memajukan kualitas pendidikan di Indonesia. Mulai dari memberikan berbagai macam pelatihan kepada guru-guru serta memperbaharui kurikulum. Namun hingga saat ini hasil yang didapatkan dari upaya tersebut belum optimal. Fakta tersebut dapat dilihat dari rata-rata nilai ujian nasional SMP tahun 2018 yaitu 52,96 yang mengalami penurunan dari ujian nasional SMP tahun 2017 yang memperoleh nilai rata-rata 55,51. Fakta lain juga menunjukkan bahwa ratarata nilai UN tingkat Sekolah Menengah Pertama (SMP) tahun 2018 khususnya pelajaran matematika yang juga mengalami penurunan (Putri, 2018: 1). Menurut pengamat pendidikan, Indra Charismiadji, salah satu penyebab rendahnya nilai matematika adalah metode pendidikan yang belum sesuai. Menurut (Syahmadani, 2018: 1) hal ini disebabkan model pembelajaran pada saat ini diajarkan di sekolah masih berada di tingkat menghafal dan memahami.

Ansari (2016: 4) berpendapat perlu adanya reformasi model pembelajaran matematika di kelas untuk mengantisipasi kemajuan teknologi dan perkembangan ilmu pengetahuan. Tugas dan peran guru tidak hanya penyampai informasi (transfer of knowledge), melainkan selaku pengerak belajar (simulation of learning) yang bertujuan supaya siswa bisa membangun sendiri pengetahuan dengan berbagai macam kegiatan pemecahan masalah, berkomunikasi (doing math) dan penalaran demi sarana siswa untuk melatihan berpikir kritis dan kreatif. Peraturan menteri pendidikan dan kebudayaan No 21 Tahun 2016 menegaskan bahwa salah satu yang harus ada pada 
siswa adalah kemampuan mengomunikasikan suatu gagasan matematika dengan tepat. Oleh karena itu, kemampuan komunikasi matematis harus ditumbuhkembangkan dalam dunia pendidikan dari sejak dini.

Baroody (Ansari, 2016: 5) berpendapat setidajnya ada dua macam alasan, pentingnya mengembangkan komunikasi dalam pelajaran matematika. Pertama, mathematics as language, dapat diartikan matematika bukan hanya alat bantu saat berpikir (a tool to aid thinking), alat dalam mendapatkan pola, mengambil kesimpulan atau memecahkan masalah, melainkan matematika dapat menjadi salah satu alat untuk mengomunikasikan ide-ide secara cermat dan jelas. Kedua, mathematics learning as social activity; artinya pembelajaran matematika selaku kegiatan sosial, matematika juga berupa sarana penghubung antar siswa serta komunikasi terhadap guru dan siswa. Hal tersebut menunjukkan pentingnya untuk mempercepat pemahaman matematika siswa. Greenes dan Schulman (Nuraeni dan Luritawaty, 2016: 102) menyatakan bahwa komunikasi matematis merupakan kekuatan utama bagi siswa untuk menyusun konsep dan strategi matematika; seumpama modal kesuksesan siswa terhadap pendekatan dan penyelesaian saat eksplorasi dan investigasi matematika; komunikasi menjadi tempat bagi siswa untuk memperoleh informasi atau berbagi pikiran, menilai dan menajamkan ide untuk meyakinkan seseorang.

Dalam kegiatan belajar mengajar, komunikasi yang terjadi haruslah komunikasi multi arah diantara guru dan siswa bisa diartikan siswa akan memberi respon setelah guru selesai menjelaskan suatu hal, misalnya berupa pertanyaan-pertanyaan jika ketika guru menyampaikan masih ada yang kurang dimengerti maka siswa akan dengan spontan akan menanyakan bagian yang masih belum dipahami. Guru juga sebaiknya memahami bentuk komunikasi yang efektif agar pesan yang ingin disampaikan kepada siswa lebih mudah dipahami. Komunikasi yang tercipta pun bukan hanya sekedar komunikasi lisan, melainkan dapat pula komunikasi secara tertulis. Menurut Los Angeles Country Office of Education (dalam Mahmudi, 2009: 3) menjelaskan bahwa komunikasi matematik terdiri dari dua cakupan yaitu komunikasi tertulis dan lisan. Komunikasi tertulis dapat berupa, gambar, table, penggunaan kata-kata, dan sebagainya yang dapat menggambarkan proses berpikir siswa. Komunikasi tertulis juga dapat berbentuk uraian pemecahan masalah atau pembuktian matematika yang menggambarkan kemampuan siswa dalam mengkontruksi berbagai konsep penyelesaikan masalah. Sedangkan komunikasi lisan dapat berbentuk ungkapan dan penjelasan verbal suatu gagasan matematika. Komunikasi lisan bisa terjadi melalui interaksi antar siswa contohnya dalam pembelajaran yang disetting agar siswa dapat berdiskusi antar kelompok.

Pentingnya membangun komunikasi yang baik saat proses pembelajaran juga dijelaskan oleh Herdian (2010: 1) yang mana telah ia berpendapat saat proses belajar mengajar matematika di kelas, komunikasi gagasan matematika dapat terjadi antar siswa dengan siswa, guru dengan siswa, dan buku dengan siswa. Baiknya komunikasi yang tercipta dapat memberikan pengaruh positif kepada siswa sehingga siswa memiliki tanggung jawab untuk menciptakan suasana belajar yang baik. Siswa yang merasa 
Vol 1 No 22020 Desember 2020

Jurnal AlphaEuclidEdu

bahwa mereka terlibat secara aktif dalam proses pembelajaran dapat membantu meningkatnya rasa percaya diri siswa saat mengikuti proses belajar. Rasa percaya diri yang baik dapat memacu siswa untuk lebih mudah menyampaikan pendapatnya tentang materi yang dipelajari.

Percaya diri atau sering disebut Self Confidence sangat diperlukan siswa untuk mengomunikasikan berbagai macam keluhan yang didapat saat belajar. Rakhmat (2012: 107) mengungkapkan bahwa masalah-masalah yang dialami siswa dalam komunikasi akan menyebabkan siswa yang rendah percaya diri sering menghindari momen komunikasi, sehingga saat diskusi berlangsung siswa akan lebih banyak diam. Pendapat itu sependapat dengan penelitian yang dilaksanakan oleh Jumalia (2018: 59) yang menunjukkan bahwa kepercayaan diri mempengaruhi kemampuan komunikasi matematika sebanyak $74,1 \%$ pada hasil belajar. Pentingnya self confidence dalam dunia pendidikan tercantum didalam Permendikbud No. 21 Tahun 2016 tentang standar isi, yang memuat bahwa percaya diri merupakan satu diantara sikap sosial yang harus dimiliki siswa.

Untuk menguatkan dugaan-dugaan tersebut, peneliti melakukan prariset di kelas VIII C SMP Muhammadiyah 1 Pontianak pada tanggal 12 Februari 2019, berupa pemberian soal tes Sistim Persamaan Linear Dua Variabel (SPLDV) dan angket self confidence. Dari hasil prariset tersebut, diperoleh rata-rata nilai tes yang diberikan kepada 29 orang siswa pada materi SPLDV yaitu 35,17. Dapat dikatakan bahwa ratarata nilai saat pemberian tes cukup jauh dibawah nilai ketuntasan belajar minimum (KBM) matematika yaitu 70. Berdasarkan hasil jawaban beberapa siswa diperoleh fakta bahwa siswa belum bisa menggunakan simbol-simbol matematika dengan benar, siswa belum mampu untuk mengubah situasi matematika menjadi ide matematika berupa SPLDV, siswa belum mampu menganalisis strategi apa yang pada digunakan untuk menyelesaikan suatu persoalan. Berdasarkan permasalahan yang telah diuraikan, terdapat indikasi ternyata kemampuan komunikasi matematis siswa dikategorikan rendah saat mengerjakan soal terkait berhubungan dengan materi SPLDV.

Selain pemberian soal tes kemampuan komunikasi matematis, peneliti juga memberikan angket untuk mengetahui self confidence yang dimiliki siswa. Berdasarkan hasil angket yang diberikan kepada 29 siswa kelas VIII C, diperoleh 15 siswa yang kurang percaya akan kemampuan dirinya sendiri. Selain itu, terdapat 14 siswa yang merasa frustasi jika mendapatkan nilai rendah. Rasa frustasi ini menunjukkan bahwa mereka memberikan reaksi yang kurang baik terhadap kegagalan yang dialami. Terdapat pula 16 siswa yang tidak berani mengerjakan soal di papan tulis dan 15 siswa yang belum berani mengajukan pertanyaan. Fakta ini diperkuat dari hasil wawancara peneliti terhadap beberapa siswa yang mengaku belum berani bertanya karena takut mendapatkan penolakan, baik dari guru maupun teman sekelas. Berdasarkan hasil angket dan wawancara tersebut, peneliti mengasumsikan bahwa masih terdapat siswa yang memiliki tingkat self confidence rendah.

Hasil tes dan angket yang telah diberikan sejalan dengan pernyataan Rakhmat (2012:103) yang menyatakan bahwa orang yang minder akan menemui kerumitan 
Vol 1 No 22020 Desember 2020

Jurnal AlphaEuclidEdu

dalam mengomunikasikan idenya pada orang yang diseganu, tidak sanggup berbicara di depan umum, atau ragu-ragu menyampaikan pandangannya. Naim (2017: 91) juga menyatakan bahwa seorang pembicara yang kurang percaya diri, akan menciptakan timbulnya rasa takut karena ia akan menjadi pusat perhatian banyak orang.

Menurut NCTM (2000: 60) faktor yang penyebab rendahnya kemampuan komunikasi matematis dikarenakan matematika lebih dominan disampaikan dalam bentuk simbol, sehingga komunikasi lisan maupun tertulis tentang ide-ide matematika tidak selalu menjadi bagian penting dari pendidikan matematika. Selain itu pada penelitian yang dilakukan oleh Darkasyi (2014: 22) menampakkan bahwa guru cenderung lebih aktif dibandingkan siswa, dimana guru lebih sering menerapkan metode ceramah saat penyampaian materi. Pembelajaran dengan metode ceramah dapat membuat siswa tidak terbiasa untuk mengomunikasikan gagasan yang mereka miliki serta hanya fokus dengan penyampaian yang diberikan oleh guru. Anggapan tersebut sepaham dengan hasil penelitian yang telah dilaksanakan oleh Shimada (2006: 63) yang menunjukkan pada saat pembelajaran, seorang guru memiliki peran lebih banyak dan penyampaian yang didapat hanya berjalan satu arah, yaitu dari guru terhadap siswa, dengan demikian dapat menyebabkan siswa menjadi tidak aktif. Sedangkan Kurikulum 2013 lebih menekankan pembelajaran aktif, dimana guru hanya menuntun siswa untuk mencari tahu sehinga proses belajar mengajar lebih berpusat kepada siswa.

Berdasarkan Silabus Mata Pelajaran Matematika tingkat SMP Kurikulum 2013, materi SPLDV merupakan satu diantara materi yang wajib dipahami dan dikuasai oleh siswa dalam pembelajaran matematika. Selain itu, dari hasil wawancara pada guru matematika kelas VIII ditanggal 11 Februari 2019, diketahui bahwa nilai siswa pada materi SPLDV mengalami penurunan. Fakta tersebut juga didukung dengan pemberian soal SPLDV pada saat prariset, dimana rata-rata siswa hanya mampu mengerjakan 2 soal dengan benar dari 4 butir soal yang diberikan. Salah satu penyebab materi SPLDV dianggap sulit karena materi ini menuntut siswa untuk mengomunikasikan ide-ide matematikanya agar dapat menyelesaikan permasalahan.

Berdasarkan uraian sebelumnya, maka peneliti melakukan penelitian yang berjudul "Kemampuan Komunikasi Matematis Siswa Dikaji Dari Self Confidence Pada Materi Sistem Persamaan Linear Dua Variabel Di SMP Muhammadiyah 1 Pontianak".

\section{Metode Penelitian}

Metode penelitian adalah upaya ilmiah untuk mengumpulkan data dengan maksud dan tujuan tertentu (Sugiyono, 2015: 24). Metode penelitian yang diterapkan pada penelitian ini adalah metode penelitian deskriptif, karena tujuannya memberikan pandangan tentang kemampuan komunikasi matematis siswa yang dikaji dari self confidence. Subjek penelitian dibatasi sebanyak enam siswa dengan rincian tiga siswa yang mempunyai tingkat self confidence rendah dan tiga siswa dengan tingkat self confidence tinggi.

Metode penelitian deskriptif adalah metode penelitian yang dilakukan untuk menjelaskan dengan akurat, terperinci dan nyata mengenai sifat dan fakta pada populasi tertentu. Dalam penelitian deskriptif hanya menggambarkan sesuatu apa adanya, tidak 
Vol 1 No 22020 Desember 2020

Jurnal AlphaEuclidEdu

untuk mencari atau menerangkan keterkaitan antar variabel (Sanjaya, 2013: 59). Penelitian ini akan melihat dan mendeskripsikan fakta di lapangan mengenai kemampuan komunikasi matematis dikaji dari self confidence dalam materi SPLDV apa adanya.

\subsection{Tahap Persiapan}

Langkah-langkah yang dilaksanakan saat tahap persiapan yaitu: (1) Melakukan prariset; (2) Membuat instrumen penelitian yang berupa kisi-kisi angket tingkat self confidence, angket tingkat self confidence, kisi-kisi tes kemampuan komunikasi matematis, soal tes kemampuan komunikasi matematis, kunci jawaban tes kemampuan komunikasi matematis, rubrik penskoran tes kemampuan komunikasi matematis, pedoman wawancara dan kisi-kisi wawancara; (3) Melaksanakan validasi pada instrumen penelitian; (4) Melakukan revisi instrumen tes berdasarkan pada hasil validasi; (5) Melaksanakan uji coba instrumen penelitian di SMP Islam Al-Azhar 17 Pontianak; (6) Menganalisis hasil uji coba instrumen penelitian; (7) Mengatur jadwal pelaksanaan penelitian dengan menanyakan pada guru matematika.

\subsection{Tahap Pelaksanaan}

Langkah-langkah persiapan antara lain: (1) Memberikan angket tingkat self confidence kepada siswa; (2) Menganalisis angket tingkat self confidence siswa; (3) Mengelompokkan siswa berdasarkan tingkat self confidence (rendah dan tinggi) yang diperoleh dari hasil angket tingkat self confidence; (4) Menetapkan subjek penelitian yaitu tiga orang dengan tingkat self confidence rendah, dan tiga orang dengan tingkat self confidence tinggi; (5) Memberikan soal tes kemampuan komunikasi matematis kepada subjek penelitian; (6) Mewawancarai subjek penelitian untuk melengkapi informasi yang diperoleh dari hasil tes; (7) Menganalisis hasil tes kemampuan komunikasi matematis dan wawancara berdasarkan tingkat self confidence siswa.

\subsection{Tahap Pengolahan Data}

Langkah-langkah pada saat mengolah data meliput: (1) Mendeskripsikan hasil analisis tes kemampuan komunikasi matematis dan wawancara berdasarkan pada tingkat self confidence rendah dan self confidence tinggi; (2) Membuat laporan hasil penelitian.

\section{Hasil dan Pembahasan}

\subsection{Hasil Penelitian}

Angket self confidence diberikan kepada 28 siswa kelas IX A SMP Muhammadiyah 1 Pontianak yang berisi 32 item pernyataan (16 item pernyataan favourable dan 16 item pernyataan unfavourable yang mencakup unsur-unsur melihat tingkat self confidence siswa. Data dari hasil angket yang telah dijawab siswa, selanjutnya diolah dengan bantuan Microsoft Excel. Interpretasi skor skala self confidence tidak bisa dilakukan secara langsung sehingga peneliti mengubah respon subjek dengan skor angka. Untuk mendapatkan hasil dari skor angka, peneliti mengubah respon subjek tiap item pernyataan menjadi sebuah skor berdasarkan pernyataan favourable dan unfavourable. Hasil angket self confidence siswa kelas IX A SMP Muhammadiyah 1 Pontianak dapat dilihat pada Gambar 1 dibawah ini: 
Vol 1 No 22020 Desember 2020

Jurnal AlphaEuclidEdu

Gambar 1: Representasi Tingkat Self Confidence Siswa Kelas IX A di SMP

Muhammadiyah 1 Pontianak

Berdasarkan hasil angket self confidence, diperoleh data bahwa sebanyak 6 orang mempunyai tingkat self confidence rendah dan 22 siswa mempunyai self confidence tinggi. Dari 28 siswa yang telah dikelompokkan pada masing-masing tingkat self confidence, peneliti mengambil tiga siswa secara acak yang memiliki tingkat self confidence rendah yaitu RR, AK, dan RP, serta tiga siswa yang memiliki tingkat self confidence tinggi yaitu SA, MA, dan AA.

Setelah memilih subjek berdasarkan tingkat self confidence, selanjutnya peneliti memberikan soal tes kemampuan komunikasi matematis kepada ke enam subjek tersebut yang terdiri dari lima soal essay. Pemberian tes ini dimaksudkan untuk mengungkap bagaimana kemampuan komunikasi matematis siswa yang akan dianalisis dan dijabarkan dalam bentuk narasi berdasarkan indikator kemampuan komunikasi matematis. Dari hasil penelitian yang telah diteliti, peneliti membuat rangkuman deskripsi kemampuan komunikasi matematis siswa dikaji dari tingkat self confidence pada tabel 1 berikut:

Tabel 1

Kemampuan Komunikasi Matematis Dikaji Dari Tingkat Self Confidence

\begin{tabular}{|c|c|c|}
\hline $\begin{array}{c}\text { Subjek } \\
\text { Penelitian }\end{array}$ & $\begin{array}{l}\text { Tingkat Self } \\
\text { Confidence }\end{array}$ & Deskripsi Kemampuan Komunikasi Matematis \\
\hline RR & Rendah & $\begin{array}{l}\text { Dari } 5 \text { soal yang diberikan, subjek RR hanya dapat } \\
\text { mengerjakan } 2 \text { soal. Secara tertulis dan lisan, Subjek RR } \\
\text { kurang baik dalam menyatakan situasi ke dalam ide } \\
\text { matematis, menganalisis dan mengevaluasi ide matematis } \\
\text { dalam penyelesaian permasalahan yang diberikan, } \\
\text { menggunakan simbol matematika serta mengungkapkan } \\
\text { kembali hasil penyelesaian soal. }\end{array}$ \\
\hline $\mathrm{AK}$ & Rendah & $\begin{array}{l}\text { Dari } 5 \text { soal yang diberikan, subjek AK dapat mengerjakan } \\
4 \text { soal. Secara tertulis dan lisan, subjek AK baik dalam } \\
\text { menggunakan simbol matematika. Secara lisan, subjek } \\
\text { AK juga baik dalam menyatakan situasi ke dalam ide } \\
\text { matematis. }\end{array}$ \\
\hline $\mathrm{RP}$ & Rendah & $\begin{array}{l}\text { Subjek RP mengerjakan } 4 \text { dari } 5 \text { soal yang diberikan. } \\
\text { Secara tertulis, Subjek RP kurang baik dalam menyatakan } \\
\text { situasi ke dalam ide matematis, menganalisis dan } \\
\text { mengevaluasi ide matematis, serta mengungkapkan } \\
\text { kembali hasil penyelesaian soal. Namun ia tergolong baik } \\
\text { dalam menggunakan simbol matematika. Sedangkan } \\
\text { secara lisan, subjek RP tergolong baik dalam menyatakan } \\
\text { situasi ke dalam ide matematis, menggunakan simbol } \\
\text { matematika, dan mengungkapkan kembali hasil }\end{array}$ \\
\hline
\end{tabular}




\begin{tabular}{ccc}
\hline & penyelesaian soal. \\
& Subjek AA dapat mengerjakan 5 soal yang diberikan. \\
& Selain itu, subjek AA berada dalam kategori baik dalam \\
menyatakan situasi ke dalam ide matematis, menganalisis & Tan mengevaluasi ide matematis dalam menyelesaikan \\
AA & soal, menggunakan simbol matematika, serta \\
mengungkapkan kembali hasil penyelesaian soal.
\end{tabular}

\subsection{Pembahasan}

\subsubsection{Analisis Hasil Tes Tertulis}

Berdasarkan hasil penelitian, diperoleh data mengenai kemampuan komunikasi matematis dikaji dari self confidence dalam materi SPLDV di SMP Muhammadiyah 1 Pontianak, dengan jumlah 28 siswa diketahui bahwa siswa kelas IX A SMP Muhammadiyah 1 Pontianak memiliki tingkat self confidence yang berbeda-beda yaitu 6 siswa mempunyai tingkat self confidence rendah dan 22 siswa mempunyai tingkat self confidence tinggi. Demikian juga hasil analisis data pada soal tes dan wawancara diketahui bahwa kemampuan komunikasi matematis siswa berbeda-beda dan tergantung dari tingkat self confidence yang dimilikinya. Hal ini sejalan dengan pernyataan Sidik dkk (2017: 226) bahwa kemampuan komunikasi matematis yang dimiliki siswa bervariasi tergantung pada tingkat self confidence yang dimiliki.

Berdasarkan hasil analisis data kemampuan komunikasi matematis subjek RR, AK, dan RP yang memiliki tingkat self confidence rendah, diperoleh fakta bahwa 
kemampuan komunikasi matematis tertulis ketiga subjek hanya memenuhi satu dari empat indikator kemampuan komunikasi matematis, yaitu menggunakan simbol-simbol matematika dalam menyelesaikan permasalahan. Sedangkan secara lisan, ketiga subjek dapat memenuhi dua indikator kemampuan komunikasi matematis, yaitu indikator menggunakan simbol-simbol matematika dalam menyelesaikan permasalahan, serta indikator mengungkapkan kembali hasil penyelesaian soal. Siswa dengan tingkat self confidence rendah belum dapat dikatakan memiliki kemampuan komunikasi matematis karena tidak memenuhi seluruh indikator. Hasil analisis data ini sejalan dengan penelitian yang dilakukan Subekti \& Kusuma (2016: 445) bahwa siswa dengan self confidence rendah belum dapat memenuhi semua indikator kemampuan komunikasi matematis.

Berdasarkan hasil tes dan wawancara peneliti terhadap subjek RR, AK dan RP pada indikator mengungkapkan kembali hasil penyelesaian soal terdapat kesamaan antara ketiga subjek, yaitu secara tertulis tidak semua soal yang mereka kerjakan terdapat kesimpulan dari hasil penyelesaian soal. Namun secara lisan, ketiganya dapat mengungkapkan kembali hasil penyelesaian soal yang telah mereka kerjakan. Ketiga subjek tersebut juga tidak dapat menyelesaikan seluruh soal yang diberikan. Subjek AK dan RP dapat menyelesaikan 4 soal, sedangkan subjek RR hanya dapat menyelesaikan 2 soal. Fakta tersebut menunjukkan bahwa siswa dengan tingkat self confidence rendah kurang mampu dalam menganalisis soal.

Berdasarkan analisis hasil wawancara, siswa cenderung mudah menyerah dan memilih jalan pintas dengan meminta bantuan teman dalam proses pengerjaan soal tersebut. Hal ini dilakukan oleh subjek AK dalam proses pengerjaan soal nomor 2 dan 4. Selain itu ketiga subjek juga terlalu lama dalam memahami maksud soal sehingga mereka kehabisan waku untuk menyelesaikan seluruh soal. Dengan sikap tersebut, kemampuan komunikasi matematis siswa yang memiliki tingkat self confidence rendah juga tergolong rendah. Hasil analisis data yang didapat sesuai dengan penelitian yang diteliti oleh Noviyana dkk (2019: 708) bahwa siswa yang memiliki tingkat self confidence rendah akan sulit mendapatkan prestasi yang baik karena siswa tersebut selalu berpikiran negatif dan tidak yakin terhadap kemampuannya sendiri. Selain itu, hasil analisis data ini sesuai dengan pendapat yang diungkapkan Mark Twin (dalam Ubaedy, 2007: 73) yang menyatakan bahwa kepercayaan diri adalah sesuatu yang dibutuhkan untuk meraih prestasi.

Siswa yang memiliki tingkat self confidence rendah juga mudah menyerah dan tidak memiliki keinginan untuk di-perjuangkan. Mereka juga lebih sering memposisikan diri sebagai yang terakhir dan sering kali melakukan hal yang dapat merusak kepercayaan orang lain. Sebagai contoh, siswa yang memiliki tingkat self confidence rendah cenderung mengikuti apa yang sudah diputuskan oleh teman sekelompok saat diskusi kelompok terjadi. Mereka juga kurang termotivasi untuk maju atau memperbaiki kekurangan diri yang mereka rasakan, seperti merasa tidak percaya diri saat ulangan karena tidak belajar atau tidak berani bertanya ke guru saat mereka kurang mengerti tentang materi yang sedang diajarkan. Hasil analisis data ini sesuai dengan pendapat 
Vol 1 No 22020 Desember 2020

Jurnal AlphaEuclidEdu

Ubaedy (2007: 72) bahwa orang dengan tingkat self confidence rendah biasanya tidak sanggup menciptakan bukti diri positif.

Sedangkan berdasarkan hasil analisis data kemampuan komunikasi matematis subjek AA, SA, dan MA yang memiliki tingkat self confidence tinggi, diperoleh fakta bahwa kemampuan komunikasi matematis tertulis dan lisan siswa yang memiliki self confidence tinggi bisa memenuhi seluruh indikator kemampuan komunikasi matematis, yaitu indikator mengungkapkan situasi dan gambar ke dalam ide matematis, indikator menganalisis dan mengevaluasi ide matematika dalam menyelesaikan per-masalahan, indikator menggunakan simbol-simbol matematika dalam menyelesaikan permasalahan, serta indikator mengungkapkan kembali hasil penyelesaian soal dengan baik. Siswa dengan tingkat self confidence tinggi ini sudah dapat dikatakan memiliki kemampuan komunikasi matematis yang baik karena dapat memenuhi seluruh indikator kemampuan komunikasi matematis.

Untuk siswa yang mempunyai tingkat self confidence tinggi cenderung mampu mengerjakan seluruh soal dengan baik. Baik lisan maupun tertulis, kemampuan komunikasi matematis siswa yang memiliki tingkat self confidence tinggi tergolong baik. Fakta berdasarkan hasil analisis ini sesuai dengan pendapat Rizqi dkk (2016: 91) bahwa dengan self confidence yang baik, siswa dapat mengkomunikasikan ide-ide mereka untuk mengklarifikasi pemecahan masalah yang mereka peroleh.

Jika dilihat dari hasil wawancara yang telah dilakukan, siswa dengan tingkat self confidence tinggi memiliki pandangan yang baik terhadap kemampuan yang dimiliki. Mereka juga cenderung berani menanggung konsekuensi dari apa yang mereka lakukan. Hal ini dapat terlihat saat mereka menemukan jawaban yang berbeda saat proses diskusi kelompok. Mereka berani mengalah jika memang jawaban yang mereka temukan ternyata salah. Hasil analisis data ini sesuai dengan penelitian yang dilakukan oleh Noviyana dkk (2019: 708) dimana hasil penelitian menghasilkan kemampuan komunikasi matematis siswa akan bagus jika siswa tersebut memiliki rasa percaya diri yang baik, karena pandangan positif mengenai dirinya dan kemampuannya mengakibatkan siswa tidak merasa takut salah ataupun cemas ketika menyelesaikan masalah tentang komunikasi matematis. Siswa yang memiliki self confidence yang baik juga akan berani menyampaikan pendapatnya serta akan terdorong untuk meningkatkan prestasinya.

\section{Kesimpulan}

Dari hasil analisis data yang dijabarkan dan pembahasan, umumnya bisa disimpulkan bahwa siswa dengan self confidence tinggi bisa memenuhi seluruh indikator kemampuan komunikasi matematis, namun siswa dengan tingkat self confidence rendah belum dapat memenuhi semua indikator dari kemampuan komunikasi matematis.

Secara khusus bisa disimpulkan yakni:

1. Kemampuan komunikasi matematis tertulis dikaji dari tingkat self confidence rendah dapat memenuhi indikator menggunakan simbol-simbol matematika dalam menyelesaikan permasalahan 
Vol 1 No 22020 Desember 2020

Jurnal AlphaEuclidEdu

2. Kemampuan komunikasi matematis tertulis dikaji dari self confidence tinggi bisa memenuhi seluruh indikator kemampuan komunikasi matematis.

3. Kemampuan komunikasi matematis lisan dikaji dari tingkat self confidence rendah dapat indikator menggunakan simbol-simbol matematika, dan indikator mengungkapkan kembali hasil penyelesaian soal dengan baik.

4. Kemampuan komunikasi matematis lisan dikaji dari self confidence tinggi bisa memenuhi seluruh indikator kemampuan komunikasi matematis.

\section{Referensi}

\section{Referensi berupa buku}

Ansari, Bansu I. 2016. Komunikasi Matematik Strategi Berfikir dan Manajemen Belajar: Konsep dan Aplikasi. Aceh: Pena.

Naim, Ngainun. 2017. Dasar-dasar Komunikasi Pendidikan. Yogyakarta: Ar-ruzz Media.

Rakhmat, Jalaluddin. 2012. Psikologi Komunikasi. Bandung: Remaja Rosdakarya.

Sanjaya, Wina. 2013. Penelitian Pendidikan (Jenis, Metode, dan Prosedur). Jakarta: Kencana Prenada Media Grup.

Sugiyono. 2015. Metode Penelitian Manajemen. Bandung: Alfabeta.

Ubaedy, AN. 2007. Berfikir Positif: Agar Anda Tetap Pede Menghadapi Hidup. Jakarta: Bee Media Indonesia.

\section{Referensi berupa jurnal online tanpa DOI}

Darkasyi, Muhammad, dkk. 2014. Peningkatan Kemampuan Komunikasi Matematis dan Motivasi Siswa dengan Pembelajaran Pendekatan Quantum Learning pada Siswa SMP Negeri 5 Lhokseumawe. Jurnal Didaktik Matematika Vol. 1 No. 1.

Herdian. 2010. Kemampuan Komunikasi Matematika. (Online). (http://herdy07_wordpress.com, 25 Mei 2018)

Mahmudi, Ali. 2009. Komunikasi dalam Pembelajaran Matematika. Jurnal MIPMIPA UNHALU Vol. 8 No.1.

Noviyana, I. N, dkk. 2019. Analisis Kemampuan Komunikasi Matematis Siswa Ditinjau Dari Self Confidence. Prosiding Seminar Nasional Matematika.

Nuraeni, R \& Luritawaty, I.P. 2016. Mengembangkan Kemampuan Komunikasi Matematik Siswa Melalui Strategi Think Talk Write. Jurnal Pendidikan Matematika STKIP Garut.

Putri, Zunita Amalia. 2018. Kemendikbud: Nilai Rata-rata UN SMP 2018 Alami Penurunan. Detik News.

Rizqi, A.A; Suyitno, H; \& Sudarmin. 2016. Analysis of Mathematical Communication Abilitu Viewed from Students Confidence through Blended Learning. International Conference on Mathematics, Science, and Education 2016.

Sidik, Anwar; Ramlah; \& Utami, M. R. 2017. Hubungan Antara Self Confidence Dengan Kemampuan Komunikasi Matematis Siswa SMP. Prosiding Seminar Nasional Matematika dan Pendidikan Matematika (SESIOMADIKA). 
Vol 1 No 22020 Desember 2020

Jurnal AlphaEuclidEdu

Subekti, F. E. \& Kusuma, A. B. 2016. Deskripsi Kemampuan Komunikasi Matematis Ditinjau Dari Rasa Percaya Diri Mahasiswa. Jurnal Euclid Vol.3 No.1.

Syahmadani, K. Anam. 2018. Logika Siswa Rendah, Nilai Unas SMP Turun. Jawa Pos.

\section{Referensi berupa Chapter Book}

NCTM. 2000. Principles and Standards for School Mathematics. Reston, VA: NCTM.

Shimada, S. 2006. Senior Secondary Education Project 2006. The Open Ended Approach. A New Tesis for Teaching Mathematics. Reston: Prentice Hall Inc.

\section{Referensi berupa Undang-Undang atau Peraturan Pemerintah}

Kemendikbud. 2016. Standar Isi Pendidikan Dasar dan Menengah. Jakarta:

Kementerian Pendidikan dan Kebudayaan Republik Indonesia.

\section{Referensi berupa Skripsi/Tesis/Disertasi}

Jumalia. 2018. Pengaruh Kepercayaan Diri dan Kemampuan Komunikasi Matematika Terhadap Hasil Belajar Matematika Siswa Kelas VIII SMP Negeri 5 Majene. Makassar: Skripsi Universitas Negeri Makassar. 
Vol 1 No 22020 Desember 2020

Jurnal AlphaEuclidEdu

Received: 21/10/2020; Revised: 24/11/2020; Accepted: 04/12/2020

\title{
EKSPLORASI KETERAMPILAN KERUANGAN MENGENAI KUBUS MELALUI WAWANCARA KLINIS BERBASIS MASALAH
}

\author{
${ }^{1}$ Medellu, Antonius, ${ }^{2}$ Sugiatno, ${ }^{3}$ Hartoyo, Agung \\ ${ }^{1,2,3}$ Pendidikam Matematika FKIP Universitas Tanjungpura Pontianak \\ Email: anton.medellu@yahoo.com
}

\begin{abstract}
Abtract
Students' spatial skills in solving problems related to the arrangement of cubes were relatively low. This research was conducted to describe students' spatial skills regarding cube arrangement through problembased clinical interviews. The design of this study was descriptive exploratory using one class of students as the research sample. Student tests were used to see students' initial abilities regarding cube arrangements. While problem-based clinical interviews were used to dig deeper into spatial skills and student problem solving regarding cube arrangements. The data obtained was processed using descriptive statistics such as average, cumulative frequency and percent score. Furthermore, the data was analyzed and interpreted using qualitative data analysis techniques to explain the phenomena that occur in the field. The results of the study show that the students' spatial skills regarding the cube were still relatively low; students' spatial skills were not in accordance with the concepts related to solving the problem of unit cube arrangements; students' spatial skills did not show skills related to solving problems in unit cube arrangements; to transform students' skills into spatial skills related to the problem of cube arrangement it is necessary to re-emphasize spatial skills which include spatial visual, spatial perception, spatial relations, and spatial orientation.
\end{abstract}

Keywords: Spatial Ability, Problem Based Clinical Interview

\section{Pendahuluan}

Nilai rata-rata Ujian Nasional (UN) matematika sekolah menengah pertama tahun pelajaran 2014/2015 adalah 56,28. Hasil ini merupakan nilai terendah dari seluruh mata pelajaran Ujian Nasional yang telah dilaksanakan (Kemendikbud, 2015). Hasil ini juga menunjukan rendahnya kemampuan pemecahan masalah matematika di tingkat sekolah menengah pertama. Di tingkat internasional hasil penelitian Trends in International Mathematics and Science Study (TIMSS) tahun 2011 menempatkan literasi matematika siswa SMP di Indonesia berada pada urutan ke-38 dari 42 negara (Balitbang, 2012). Hasil yang tidak jauh berbeda termuat dalam survey Programme for International Student Assessment (PISA) tahun 2012 yang menyimpulkan bahwa literasi matematika siswa Indonesia berada pada urutan 64 dari 65 negara (Balitbang, 2012). PISA juga mengungkapkan bahwa siswa Indonesia lemah dalam konsep-konsep geometri, khususnya yang berkaitan dengan pemahaman ruang dan bentuk. Sebagai ilustrasi, siswa menghadapi kesulitan dalam membayangkan bangun ruang balok yang memiliki rongga di dalamnya (Balitbang, 2012).

Salah satu kompetensi yang ingin dicapai dalam kurikulum pendidikan nasional di jenjang sekolah menengah adalah kompetensi keterampilan yang bertujuan agar siswa memiliki kemampuan untuk mencoba, mengolah, dan menyaji dalam ranah konkret (menggunakan, mengurai, merangkai, memodifikasi, dan membuat) serta ranah abstrak (menulis, membaca, menghitung, menggambar, dan mengarang) (Permendikbud, 2016). 
National Council of Teachers of Mathematics (NCTM) merekomendasikan beberapa tujuan umum siswa belajar matematika, yaitu: (1) belajar akan nilai-nilai matematika, memahami evolusi dan peran-annya dalam masyarakat dan sains; (2) percaya diri pada kemampuan yang dimiliki, percaya pada kemampuan berpikir matematis yang dimiliki dan peka terhadap situasi dan masalah; (3) menjadi seorang problem solver, menjadi warga negara yang terampil, produktif dan berpengalaman dalam memecahkan berbagai permasalahan; (4) belajar berkomunikasi secara matematis, belajar tentang simbol, lambang dan kaidah matematis; (5) belajar bernalar secara matematis yaitu membuat konjektur, bukti dan membangun argumen secara matematik (NCTM, 2000).

E.T. Russefendi (2005) mengemukakan aritmatika, aljabar, kalkulus dan geometri merupakan bagian matematika yang timbul karena pikiran-pikiran manusia yang berhubungan dengan ide, proses, dan penalaran. Geometri diajarkan di sekolah berguna untuk meningkatkan cara berpikir logis dalam membuat generalisasi secara benar. Agar dapat memahami aritmatika, aljabar, dan kalkulus, maka pemahaman konsep geometri harus dikuasai secara mendalam.

Pembelajaran geometri di pendidikan dasar dan menengah dimulai dari obyek konkret ke obyek abstrak, dari segi intuitif ke analisis, dari eksplorasi (penemuan) ke penguasaan (pemahaman), serta dari tahap yang paling sederhana hingga ke tahap yang lebih kompleks. Van Hiele menyimpulkan bahwa anak-anak dalam belajar geometri melalui beberapa tahap yaitu: visualisasi, analisis, abstraksi, deduksi, dan akurasi. Gabungan dari waktu, materi pelajaran, dan metode pengajaran yang dipakai akan meningkatkan kemampuan berpikir siswa ke tahap yang lebih tinggi (Mason, 1998).

Beberapa penelitian menyimpulkan bahwa materi geometri merupakan materi yang tergolong sulit. Hal ini dapat dilihat dari hasil Ujian Nasional SMP Tahun Pelajaran 2014/2015 dimana materi bangun geometris menempati posisi terendah dibandingkan materi lainnya (Tabel 1).

Tabel 1.

Persentase Penguasaan Materi Soal Matematika Ujian Nasional SMP Tahun Pelajaran $2014 / 2015$

\begin{tabular}{ccc}
\hline Nomor Urut & Materi Yang Diuji & Persentase \\
\hline 1 & Statistika dan Peluang & 60,78 \\
\hline 2 & Operasi Bilangan & 60,64 \\
\hline 3 & Operasi Aljabar & 57,28 \\
\hline 4 & Bangun Geometris & 52,04 \\
\hline
\end{tabular}

Keterampilan keruangan adalah bagian dari keterampilan geometri yang berkaitan dengan bangun ruang. Keterampilan dasar dalam geometri merupakan prasyarat untuk mempelajari konsep-konsep keruangan. Menurut Fennama dan Sherman (2000) keterampilan keruangan merupakan suatu bakat yang diperoleh dengan memanipulasi mental terhadap benda padat. Bakat ini muncul sebagai komponen keterampilan matematis dan memperlihatkan besarnya korelasi keterampilan visual terhadap prestasi belajar matematika sebagaimana keterampilan verbal. Catel (Ruseffendi, 2006) menyatakan salah satu persoalan matematika adalah munculnya tuntutan bagi siswa 
untuk menggunakan keterampilan nalar dan berpikir kritisnya dalam memecahkan masalah-masalah yang berkaitan dengan keruangan. Schonberger (Saragih, 2011) mengemukakan bahwa keterampilan keruangan adalah salah satu komponen utama dari kecerdasan manusia dan memiliki peran penting dalam beberapa program penempatan dan pelatihan. Hofter (1998) mengemukakan lima keteram-pilan dasar dalam belajar geometri keruangan. Kelima keterampilan tersebut meliputi: (1) Keterampilan visual, yaitu kemampuan untuk mengenal dan mengamati bangun ruang serta keterkaitannya satu dengan yang lain, kemampuan untuk mengklasifikasikan bangun geometri menurut ciri-ciri yang teramati, kemampuan untuk menyimpulkan informasi berdasarkan pengamatan visual, dan kemampuan untuk memvisualisasikan model geometri atau contoh-contoh penangkal dalam suatu sistem matematika deduktif; (2) Keterampilan verbal, yaitu kemampuan untuk menunjukkan bermacam bangun geometri menurut namanya, kemampuan untuk memvisualisasikan bangun geometri menurut deskripsi verbalnya, kemampuan untuk mengungkapkan sifat-sifat bangun geometri, merumuskan definisi dengan tepat dan benar, mengungkapkan hubungan antar bangun, kemampuan untuk mengenali struktur logis dari masalah verbal, merumuskan generalisasi dan abstraksi; (3) Keterampilan menggambar, yaitu kemampuan untuk mensketsa gambar bangun ruang menurut deskripsi verbalnya, kemampuan untuk menggambar atau mengkonstruksi bangun ruang berdasarkan sifat yang diberikan, kemampuan untuk mengkonstruksi gambar bangun ruang yang memiliki kaitan tertentu; (4) Keterampilan logika, yaitu kemampuan untuk mengenal perbedaan dan kesamaaan antar bangun geometri, kemampuan untuk menentukan apakah sebuah gambar masuk atau tidak masuk dalam kelas tertentu, kemampuan untuk memahami dan menerapkan sifat-sifat penting dari definisi, menujukkan akibat-akibat logis dari data yang diberikan, mengembangkan bukti yang logis, dan mengenal peranan dan keterbatasan metode deduktif; (5) Keterampilan terapan, yaitu kemampuan untuk mengenal model fisik dari bangun geometri, kemampuan untuk mensketsa atau mengkonstruksi model geometri berdasarkan objek fisiknya, kemampuan untuk menerapkan sifat-sifat dari model geometri dari objek fisik, kemampuan untuk mengembangkan model geometri bagi fenomena alam, dan kemampuan untuk menerapkan model-model geometri dalam pemecahan masalah.

Hasil studi PISA menyimpulkan hanya $33,4 \%$ siswa Indonesia yang mampu menjawab soal-soal geometri yang berkaitan dengan bentuk dan ruang (Wardhani dan Rumiati, 2011). Sementara prinsip pertama NCTM menyatakan bahwa keunggulan pembelajaran matematika memerlukan kesetaraan, harapan yang besar, dan dukungan yang kuat untuk semua siswa (NCTM, 2000). Prinsip ini mengindikasikan harapan yang tinggi untuk semua siswa. Semua siswa harus memiliki kesempatan dan dukungan yang cukup untuk belajar matematika, tanpa memandang karakteristik personal, latar belakang, ataupun hambatan fisik. Hal ini berarti bahwa siswa yang berkemampuan rendah harus ditangani terlebih dulu agar memiliki kemampuan cukup untuk mengikuti pembelajaran matematika. 
Vol 1 No 22020 Desember 2020

Jurnal AlphaEuclidEdu

Salah satu model pembelajaran yang dapat ditawarkan untuk mengatasi rendahnya kemampuan matematis siswa adalah metode pembelajaran wawancara klinis. Wawancara klinis memiliki kekuatan untuk menghimpun sekaligus menganalisis proses mental yang terjadi dalam pikiran siswa serta mampu menelusuri berbagai struktur kognitif yang masih tersembunyi dalam pikiran siswa (Clement, 2000). Ambrosse, dkk (2003) menyatakan wawancara klinis dapat diguna-kan para guru untuk memahami cara berpikir matematis siswa. Menurut Ginsburg (2009) wawancara klinis merupakan salah satu metode yang dapat digunakan untuk mengumpulkan data tentang hasil belajar siswa dalam penilaian formatif selain observasi dan pengujian (tes). Wawancara klinis merupakan metode yang efektif untuk menghasilkan informasi yang esensial mengenai proses kognitif yang terjadi dalam diri siswa saat ia mengerjakan sesuatu.

Terdapat beberapa studi mengenai wawancara klinis yang dapat dipakai untuk mengatasi kesulitan belajar, antara lain Lusiana (2012), Christianti (2012), dan Robeka (2012). Hasil studi yang mereka lakukan meyimpulkan bahwa wawancara klinis dapat mengurangi kesulitan belajar matematika siswa rata-rata sebesar 70\% $\square$ 90\%. Dari hasil studi ini, terlihat bahwa begitu signifikannya wawancara klinis dalam me-ngurangi kesulitan belajar siswa. Namun demikian, wawancara klinis seperti itu dikata-kan lebih bersifat menggali pemahaman dan mengidentifikasi kesulitan belajar siswa ketimbang memperbaiki/menyembuhkan mis-konsepsi siswa (Francisco, 2000; Brown, 2004; Ginsburg, 2009).

\section{Metode Penelitian}

Jenis penelitian ini adalah deskriptif eksploratif yang bertujuan menggali keterampilan keruangan siswa mengenai kubus melalui wawancara klinis berbasis masalah. Arikunto (2006) menyatakan bahwa penelitian deskriptif eksplorarif bertujuan menggali sekaligus menggambarkan suatu fenomena, keadaan, atau gejala yang terjadi di lapangan. Sedangkan menurut Kotler dan Amstrong (2006), penelitian eksploratif adalah penelitian yang bertujuan menghimpun informasi awal yang akan membantu upaya menetapkan masalah dan merumuskan hipotesis.

Arikunto (2006) memberi batasan subyek penelitian sebagai benda, hal atau orang tempat dimana variabel penelitian melekat, dan yang dipermasalahkan. Dengan kata lain subyek penelitian adalah sesuatu yang di dalam dirinya melekat atau terkandung obyek penelitian. Berdasarkan uraian ini maka yang menjadi subyek penelitian dalam penelitian ini adalah siswa kelas VIIA SMP Gembala Baik Pontianak Tahun Pelajaran 2016/2017.

Prosedur dalam penelitian ini meliputi: (1) Melakukan tes tertulis dengan topik kubus satuan. (2) Menskor hasil pekerjaan siswa. (3) Mengelompokkan siswa ke dalam kelom-pok atas, kelompok tengah, dan kelompok bawah. (4) Mengidentifikasi jawaban siswa. (5) Memilih klien/responden dari masing-masing kelompok siswa untuk dilakukan wawancara. (6) Melakukan wawancara klinis berbasis masalah. Data yang didapat selanjutnya dianalisis dan diarahkan untuk mencapai tujuan penelitian. Karena jenis penelitian ini deskriptif eksploratif dengan pendekatan cenderung 
Vol 1 No 22020 Desember 2020

Jurnal AlphaEuclidEdu

kualitatif, maka analisa datanya menggunakan statistik deskriptif dan teknik analisa data kualitatif.

Penggunaan statistik deskriptif dimaksudkan untuk menganalisa data kuan-titatif dengan tujuan melihat persentase, frekwensi kumulatif, dan tendensi sentral data. Teknik analisa data kualitatif dimaksudkan untuk menjelaskan fenomena yang terindikasi dalam data. Menurut Miles dan Huberman (Moleong, 2009) terdapat tiga tahapan dalam teknik analisa data kualitatif, yaitu reduksi data (data reduction), penyajian data (data display) dan kesimpulan/verifikasi (conclussion drawing/verification).

Reduksi data (data reduction) berarti merangkum data, memilih hal-hal pokok dalam data, memfokuskan data pada hal yang penting, mencari pola dan tema data. Pada tahap ini dilakukan pemilihan tentang relevan atau tidaknya antara data dengan tujuan penelitian. Data atau informasi yang didapat dari lapangan merupakan bahan mentah yang harus diringkas, disusun secara sistematis, serta ditonjolkan pokok-pokok pentingnya sehingga lebih mudah dikendalikan.

Penyajian data (data display) yaitu menyajikan data dalam bentuk uraian singkat, bagan/tabel, hubungan antar katagori, dan sebagainya. Penyajian data yang digunakan dalam penelitian kualitatif bersifat naratif. Hal ini dimaksudkan untuk memahami fenomena yang terjadi, merencanakan kerja selanjutnya berdasarkan apa yang dipahami. Pada tahap ini data diklasifikasikan dan disajikan sesuai dengan pokok permasalahan yang diawali dengan pengkodean pada setiap subpokok permasalahan.

Kesimpulan/verifikasi (conclussion drawing/verification), kegiatan ini dimaksudkan untuk mencari makna data yang dilakukan dengan cara mencari hubungan, persamaan, atau perbedaan data. Penarikan kesimpulan dilakukan dengan cara membandingkan kesesuaian pernyataan dari subyek penelitian dengan makna yang terkandung dengan konsep-konsep dasar (landasan teori) dalam penelitian. Selanjutnya, agar analisis data mengarah pada tujuan penelitian maka disusunlah kuantifikasi data tentang keterampilan keruangan.

\section{Hasil Penelitian dan Pembahasan}

\subsection{Hasil Penelitian}

Hasil analisis butir soal tes menyimpulkan bahwa soal yang dianggap sukar adalah soal nomor $3 \mathrm{~b}$ dan soal nomor 5. Tingkat kesukaran kedua soal tersebut sebesar 32,50\% untuk soal nomor $3 \mathrm{~b}$ dan $6,88 \%$ untuk soal nomor 5 . Untuk soal nomor $3 \mathrm{~b}$, sebanyak $73 \%$ siswa sampel penelitian memperoleh skor 0,00 dan sebanyak $16 \%$ siswa sampel penelitian memperoleh skor maksimum 4,00. Hasil selengkapnya dapat dilihat pada Tabel 2 dan Tabel 3. Sebaliknya, soal tes yang dianggap mudah adalah soal nomor 3a. Tingkat kesukaran soal tersebut mencapai 65,00\%. Adapun jumlah siswa sampel penelitian menurut perolehan skor yang diraih untuk soal nomor 3a disajikan dalam Tabel 4.

Untuk siswa kelompok atas, rata-rata skor terendah berturut-turut berada pada butir soal nomor 5 dan nomor 2a. Rata-rata skor untuk butir soal nomor 5 sebesar 0,50 (skor 
Vol 1 No 22020 Desember 2020

Jurnal AlphaEuclidEdu

maksimum 8) dengan persen skor sebesar 6,3\% dan rata-rata skor sebesar 3,33 (skor maksimum 6) dengan persen skor sebesar 55,6\% untuk butir soal nomor 2a. Sedangkan rata-rata skor tertinggi siswa kelompok atas berturut-turut terjadi pada butir soal nomor 3a, nomor 4a dan nomor 4b. Rata-rata skor untuk butir soal nomor 3a sebesar 2,00 (skor maksimum 2) dengan persen skor sebesar 100,0\%, rata-rata skor untuk butir soal nomor 4a sebesar 3,00 (skor maksimum 3) dengan persen skor sebesar 100,0\% dan ratarata skor untuk butir soal nomor $4 \mathrm{~b}$ sebesar 3,00 (skor maksimum 3) dengan persen skor sebesar $100,0 \%$.

Tabel 2

Jumlah Siswa Berdasarkan Perolehan Skor Tes Awal untuk Soal Nomor 3b

\begin{tabular}{cccc}
\hline No & Skor & Jumlah Siswa & Persentase (\%) \\
\hline 1. & 0 & 27 & 73 \\
\hline 2. & 1 & 0 & 0 \\
\hline 3. & 2 & 4 & 11 \\
\hline 4. & 3 & 0 & 0 \\
\hline 5. & 4 & 6 & 16 \\
\hline Total & & 37 & 100 \\
\hline
\end{tabular}

Tabel 3

Jumlah Siswa Berdasarkan Perolehan Skor Tes Awal untuk Soal Nomor 5

\begin{tabular}{lccc}
\hline No & Skor & Jumlah Siswa & Persentase $(\%)$ \\
\hline 1. & 0 & 27 & 73 \\
\hline 2. & 1 & 3 & 8 \\
\hline 3. & 2 & 6 & 16 \\
\hline 4. & 3 & 0 & 0 \\
\hline 5. & 4 & 1 & 3 \\
\hline 6. & 5 & 0 & 0 \\
\hline 7. & 6 & 0 & 0 \\
\hline 8. & 7 & 0 & 0 \\
\hline 9. & 8 & 0 & 100 \\
\hline Total & & 37 & \\
\hline
\end{tabular}

Untuk siswa kelompok tengah, rata-rata skor terendah berturut-turut terjadi pada butir soal nomor $4 \mathrm{~b}$ dan nomor $4 \mathrm{a}$. Rata-rata skor untuk butir soal nomor $4 \mathrm{~b}$ sebesar 0,00 (skor maksimum 5) dengan persen skor sebesar 0,0\% dan rata-rata skor sebesar 0,13 (skor maksimum 3) dengan persen skor sebesar 4,17\% untuk butir soal nomor $4 \mathrm{a}$. Sedangkan rata-rata skor tertinggi siswa kelompok tengah, berturut-turut berada pada butir soal nomor 3a dan nomor 1a. Rata-rata skor untuk butir soal nomor 3a sebesar 1,37 (skor maksimum 2) dengan persen skor sebesar 58,3\% dan rata-rata skor untuk butir soal nomor 1a sebesar 2,33 (skor maksimum 4) dengan persen skor sebesar 58,3\%.

Untuk siswa kelompok bawah, rata-rata skor terendah berturut-turut berada pada butir soal nomor 1b, 1c, 2a, 2b, 3b, 4a dan 4b. Rata-rata skor untuk ketujuh butir soal tersebut adalah 0,00 dengan persen skor sebesar 0,0\%. Sedangkan rata-rata skor dan persen skor tertinggi yang diperoleh siswa kelompok bawah berada pada butir soal 
nomor 1a, nomor 3a dan nomor 5. Rata-rata skor 1,00 dan persen skor 25,0\% untuk soal nomor 1a, rata-rata skor 0,40 dan persen skor $10,0 \%$ untuk soal nomor 3 a, serta rata-rata skor 0,40 dan persen skor $10,0 \%$ untuk nomor 5 .

Dari Tabel 4 terlihat bahwa siswa kelompok atas memperoleh persen skor sempurna 100\% untuk butir soal nomor 3a, 4a dan 4b. Aspek keterampilan keruangan yang diukur oleh ketiga butir soal tersebut adalah spasial visual, spasial persepsi (yang meliputi ketetapan perseptual, persepsi terhadap posisi dalam ruang, persepsi terhadap hubungan keruangan), spasial relasi, dan spasial orientasi.

Persen skor rata-rata terendah siswa kelompok atas berturut-turut berada pada butir soal nomor 5, nomor 2a, dan nomor $2 \mathrm{~b}$. Adapun aspek keterampilan keruangan yang diukur oleh ketiga butir soal tersebut meliputi spasial visual, spasial persepsi (ketetapan perseptual dan persepsi terhadap hubungan keruangan), spasial relasi, dan spasial orientasi.

Tabel 4

Rata-rata Skor dan Persen Skor tiap Butir Soal Berdasarkan Kelompok Siswa

\begin{tabular}{|c|c|c|c|c|c|c|c|c|c|c|c|}
\hline \multirow{2}{*}{$\begin{array}{c}\text { Kelompok } \\
\text { Siswa }\end{array}$} & \multirow{2}{*}{ Aspek } & \multicolumn{10}{|c|}{ Nomor Soal (skor maks) } \\
\hline & & $1 \mathrm{a}(4)$ & $1 b(4)$ & $1 \mathrm{c}(4)$ & $2 \mathrm{a}(6)$ & $2 b(6)$ & $3 a(2)$ & $3 b(4)$ & $4 a(3)$ & $4 b(5)$ & $5(8)$ \\
\hline \multirow{2}{*}{ Atas } & $\begin{array}{l}\text { Rata-rata } \\
\text { Skor } \\
\end{array}$ & 3,17 & 3,00 & 3,00 & 3,33 & 3,67 & 2,00 & 3,67 & 3,00 & 5,00 & 0,50 \\
\hline & Persen Skor & $79,2 \%$ & $75,0 \%$ & $75,0 \%$ & $55,6 \%$ & $61,1 \%$ & $100,0 \%$ & $91,7 \%$ & $100,0 \%$ & $100,0 \%$ & $6,3 \%$ \\
\hline \multirow{2}{*}{ Tengah } & $\begin{array}{l}\text { Rata-rata } \\
\text { Skor } \\
\end{array}$ & 2,33 & 1,92 & 1,83 & 2,17 & 1,83 & 1,17 & 0,25 & 0,13 & 0,00 & 0,42 \\
\hline & Persen Skor & $58,3 \%$ & $47,9 \%$ & $45,8 \%$ & $36,2 \%$ & $30,6 \%$ & $58,3 \%$ & $6,25 \%$ & $4,17 \%$ & $0,0 \%$ & $5,2 \%$ \\
\hline \multirow{2}{*}{ Bawah } & $\begin{array}{l}\text { Rata-rata } \\
\text { Skor } \\
\end{array}$ & 1,00 & 0,00 & 0,00 & 0,00 & 0,00 & 0,40 & 0,00 & 0,00 & 0,00 & 0,40 \\
\hline & Persen Skor & $25,0 \%$ & $0,0 \%$ & $0,0 \%$ & $0,0 \%$ & $0,0 \%$ & $10,0 \%$ & $0,0 \%$ & $0,0 \%$ & $0,0 \%$ & $5,0 \%$ \\
\hline
\end{tabular}

Untuk siswa kelompok tengah persen skor tertinggi diperoleh pada butir soal nomor 1a sebesar 58,3\%, nomor 1 b sebesar $47,9 \%$, dan nomor 3a sebesar 58,3\%. Adapun aspek keterampilan keruangan yang diukur untuk butir soal nomor 1a adalah spasial visual dan spasial persepsi yang meliputi persepsi terhadap posisi dalam ruang serta persepsi terhadap hubungan keruangan. Sedangkan persen skor terendah siswa kelompok tengah diperoleh pada butir soal nomor 4 a sebesar $4,17 \%$, nomor 4 b sebesar $0,00 \%$, dan nomor 5 sebesar 5,2\%. Adapun aspek keterampilan keruangan yang diukur untuk butir soal nomor $4 \mathrm{a}$, nomor $4 \mathrm{~b}$ dan nomor 5 adalah spasial visual; spasial persepsi yang meliputi ketetapan perseptual, persepsi terhadap hubungan keruangan; spasial relasi; dan spasial orientasi.

Persen skor tertinggi siswa kelompok bawah diperoleh pada butir soal nomor 1a sebesar $25,0 \%$, nomor 3 a sebesar $10,0 \%$, dan nomor 5 sebesar 10,0\%. Sedangkan untuk butir soal nomor 1b, 1c, 2a, 2b, 3b, 4a, dan 4b masing-masing memperoleh persen skor sebesar $0,0 \%$. Hasil ini menunjukan bahwa siswa kelompok bawah memiliki keterampilan keruangan yang sangat rendah.

Hasil wawancara menyimpulkan bahwa siswa kelompok atas memberi jawaban/res-pon positif tentang kemampuan keruangan yang mereka pahami. Siswa kelompok tengah memberi jawaban/respon yang bervariasi mengenai kemampuan 
Vol 1 No 22020 Desember 2020

Jurnal AlphaEuclidEdu

keruangan siswa. Bervariasi artinya terdapat butir pertanyaan wawancara yang dijawab secara positif, namun ada pula yang dijawab secara negatif. Sedangkan untuk siswa kelompok bawah, hasil wawancara menyimpulkan bahwa mereka selalu memberi jawaban/respon yang negatif tentang kemampuan keruangan (spatial ability).

\subsection{Pembahasan}

\subsubsection{Analisis Hasil Tes Tertulis}

Proses penyelesaian tes tertulis oleh para siswa menghasilkan rata-rata pencapaian (daya serap) sebesar 31,6\%. Daya serap ini mengindikasikan rendahnya kemampuan siswa untuk menyelesaikan soal-soal yang berkaitan dengan susunan kubus. Daya serap ini juga menunjukkan kemampuan pemecahan masalah tentang kubus satuan belum tuntas diserap oleh sebagian besar siswa sampel penelitian (Kemendikbud, 2014).

Hasil analisis tes tertulis menyimpulkan bahwa soal yang dianggap sukar adalah soal nomor $3 \mathrm{~b}$ dan soal nomor 5. Berdasarkan hasil yang dicapai untuk soal nomor $3 \mathrm{~b}$ dapat disimpulkan bahwa sebagian besar siswa sampel penelitian tidak mampu menentukan banyak kubus satuan dalam bangun ruang berbentuk balok variatif tampak depan dan tampak samping. Sedangkan keterampilan keruangan yang tidak dikuasai untuk soal nomor 3b adalah: (1) Keterampilan logika: siswa tidak mampu memanipulasi ide-ide terkait untuk menghi-tung banyak kubus yang disajikan dalam gambar bangun ruang berbentuk balok variatif tampak depan dan tampak samping. (2) Keterampilan terapan: siswa tidak mampu menentukan hubungan konsep dan prinsip untuk menghitung banyak kubus yang disajikan dalam gambar bangun ruang berbentuk balok variatif tampak depan dan tampak samping (Hofter, 1998).

Untuk soal nomor 5 dapat disimpulkan bahwa sebagian besar siswa sampel penelitian tidak mampu menyelesaikan soal cerita kontekstual yang berkaitan dengan ukuran kotak (kubus/balok). Sedangkan keterampilan keruangan yang tidak dikuasai untuk soal tersebut adalah: (1) Keterampilan visual: siswa tidak mampu mengidentifikasi fakta melalui gambar, tidak mampu menafsirkan tanda-tanda (simbol/gambar) dan istilah, tidak mampu memanipulasi ide-ide terkait dan tidak mampu menyempurnakan hubung-an konsep dan prinsip yang berkaitan dengan volume balok/kubus.(2) Keterampilan logika: siswa tidak mampu menafsirkan tanda-tanda, simbol, gambar dan istilah bahwa siswa dapat menafsirkan persoalan yang dimaksud adalah susunan kubus dalam balok. (3) Keterampilan terapan: siswa tidak mampu memanipulasi ide-ide terkait bahwa untuk menghitung banyak kubus bahwa siswa dapat menghitungnya melalui banyak kubus tiap lapisan kemudian menjumlahkannya. Siswa tidak mampu menyempurnakan hubungan konsep dan prinsip bahwa untuk menghitung banyak kubus siswa dapat mengaitkannya dengan konsep volume balok panjang $\mathrm{x}$ lebar $\mathrm{x}$ tinggi.

Untuk siswa kelompok atas, rata-rata skor terendah berturut-turut berada pada butir soal nomor 5 dan nomor 2a. Sedangkan rata-rata skor tertinggi siswa kelompok atas berturut-turut terjadi pada butir soal nomor 3a, nomor 4a dan nomor 4b. Mengacu pada kisi-kisi butir soal nomor 5 dapat disimpulkan bahwa sebagian besar siswa kelompok 
atas: (1) tidak mampu mengidentifikasi fakta dalam soal cerita kontekstual menentukan kotak mana yang lebih besar. (2) tidak mampu menafsirkan tanda-tanda, simbol, gambar dan istilah yang termuat dalam soal cerita kontekstual menentukan kotak mana yang lebih besar. (3) tidak mampu memanipulasi ide-ide terkait dalam soal cerita kontekstual untuk menentukan kotak mana yang lebih besar. (4) tidak mampu menyempurnakan hubungan konsep dan prinsip bahwa untuk menghitung banyak kubus siswa dapat mengaitkannya dengan konsep volume balok panjang $\mathrm{x}$ lebar $\mathrm{x}$ tinggi.

Mengacu pada kisi-kisi butir soal nomor 2a dapat disimpulkan bahwa sebagian besar siswa kelompok atas: (1) cukup mampu mengidentifikasi fakta untuk menentukan banyak kubus dalam gambar balok yang tersusun dari kubus tidak lengkap. (2) cukup mampu menyempurnakan hubungan konsep dan prinsip untuk menentukan banyak kubus dalam gambar balok yang tersusun dari kubus tidak lengkap. Untuk menghitung banyak kubus tersebut siswa dapat mengaitkannya dengan konsep volume balok panjang $\mathrm{x}$ lebar $\mathrm{x}$ tinggi. Hitung masing-masing banyak kubus pada bagian panjang, lebar dan tingginya, kemudian dikalikan.

Berdasarkan hasil yang dicapai untuk butir soal nomor 3a, 4a dan $4 \mathrm{~b}$ dapat disimpulkan bahwa sebagian besar siswa kelompok atas: (1) mampu memanipulasi ideide terkait bahwa untuk menghitung banyak kubus siswa dapat menghitungnya melalui banyak kubus tiap lapisan kemudian menjumlahkannya. (2) mampu menyem-purnakan hubungan konsep dan prinsip bahwa untuk menghitung banyak kubus siswa dapat mengaitkannya dengan konsep volume balok panjang $\mathrm{x}$ lebar $\mathrm{x}$ tinggi.

Untuk siswa kelompok tengah, rata-rata skor terendah berturut-turut terjadi pada butir soal nomor $4 \mathrm{~b}$ dan nomor $4 \mathrm{a}$. Sedangkan rata-rata skor tertinggi siswa kelompok tengah,berturut-turut berada pada butir soal nomor 3a dan nomor 1a. Mengacu pada kisi-kisi butir soal nomor $4 \mathrm{~b}$ dan nomor 4a dapat disimpulkan bahwa siswa kelompok tengah: (1) tidak mampu memanipulasi ide-ide terkait bahwa untuk menghitung banyak kubus siswa dapat menghitungnya melalui banyak kubus tiap lapisan kemudian menjumlahkannya. (2) tidak mampu menyempurnakan hubungan konsep dan prinsip bahwa untuk menghitung banyak kubus siswa dapat mengaitkannya dengan konsep volume balok panjang $\mathrm{x}$ lebar $\mathrm{x}$ tinggi. Hitung masing-masing banyak kubus pada bagian panjang, lebar dan tingginya, kemudian dikalikan. Berdasarkan hasil yang dicapai untuk butir soal nomor 3a dapat disimpulkan bahwa sebagian besar siswa kelompok tengah: (1) cukup mampu memanipulasi ide-ide terkait bahwa untuk menghitung banyak kubus siswa dapat menghitungnya melalui banyak kubus tiap lapisan kemudian menjumlahkannya. (2) cukup mampu menyempurnakan hubungan konsep dan prinsip bahwa untuk menghitung banyak kubus siswa dapat mengaitkannya dengan konsep volume balok panjang x lebar x tinggi. Berdasarkan hasil yang dicapai untuk butir soal nomor 1a dapat disimpulkan bahwa sebagian besar siswa kelompok tengah: (1) cukup mampu mengidentifikasi fakta melalui gambar untuk menentukan banyak kubus satuan dalam balok yang tersusun dari kubus. (2) cukup mampu memanipulasi ide-ide terkait untuk menentukan banyak kubus satuan dalam balok yang tersusun dari kubus. Untuk menghitung banyak kubus tersebut, siswa dapat 
menghitungnya melalui banyak kubus tiap lapisan kemudian menjumlahkannya. (3) cukup mampu menyempurnakan hubungan konsep dan prinsip untuk menentukan banyak kubus satuan dalam balok yang tersusun dari kubus. Untuk menghitung banyak kubus siswa dapat mengaitkannya dengan konsep volume balok panjang $\mathrm{x}$ lebar $\mathrm{x}$ tinggi. Hitung masing-masing banyak kubus pada bagian panjang, lebar dan tingginya, kemudian dikalikan.

Untuk siswa kelompok bawah, rata-rata skor terendah berturut-turut berada pada butir soal nomor 1b, 1c, 2a, 2b, 3b, 4a dan 4b. Sedangkan rata-rata skor dan persen skor tertinggi yang diperoleh siswa kelompok bawah berada pada butir soal nomor 1a, nomor 3a dan nomor 5. Berdasarkan hasil tersebut dapat disimpulkan bahwa siswa kelompok bawah: (1) tidak mampu mengidentifikasi fakta melalui gambar bahwa gambar balok tersusun dari kubus. (2) tidak mampu memanipulasi ide-ide terkait bahwa untuk menghitung banyak kubus siswa dapat menghitungnya melalui banyak kubus tiap lapisan kemudian menjumlahkannya. (3) tidak mampu menyempurnakan hubungan konsep dan prinsip bahwa untuk menghitung banyak kubus siswa dapat mengaitkannya dengan konsep volume balok panjang $\mathrm{x}$ lebar $\mathrm{x}$ tinggi. Hitung masing-masing banyak kubus pada bagian panjang, lebar dan tingginya, kemudian dikalikan. (4) tidak mampu mengidentifikasi fakta melalui gambar bahwa gambar balok tersusun dari kubus. (5) tidak mampu menyempurnakan hubungan konsep dan prinsip bahwa untuk menghitung banyak kubus siswa dapat mengaitkannya dengan konsep volume balok panjang $\mathrm{x}$ lebar $\mathrm{x}$ tinggi. Hitung masing-masing banyak kubus pada bagian panjang, lebar dan tingginya, kemudian dikalikan. (6) tidak mampu memanipulasi ide-ide terkait bahwa untuk menghitung banyak kubus siswa dapat menghitungnya melalui banyak kubus tiap lapisan kemudian menjumlahkannya. (7) tidak mampu menyempurnakan hubungan konsep dan prinsip bahwa untuk menghitung banyak kubus siswa dapat mengaitkannya dengan konsep volume balok panjang $\mathrm{x}$ lebar $\mathrm{x}$ tinggi. Analisis Kemampuan

\section{Keruangan Siswa}

Siswa kelompok atas memperoleh persen skor sempurna $100 \%$ untuk butir soal nomor 3a, 4a dan 4b. Berkaitan dengan hasil tersebut dapat ditarik kesimpulan bahwa siswa kelompok atas: (1) memiliki kemampuan spasial visual tentang susunan kubus sederhana maupun variatif, yaitu: kemampuan untuk mengamati dan membayangkan bentuk susunan kubus sederhana atau variatif berdasarkan stimulus yang diberikannya. Stimulus atau rangsangan ini dapat berupa rotasi, pembalikan, perubahan orientasi (misal perubahan arah penglihatan), atau stimulus lainnya. Hal ini sejalan dengan pendapat Thurstone (Mohler, 2008) yang menyatakan bahwa visualisasi spasial yang didefinisikan sebagai kemampuan untuk mengenali bagian-bagian objek jika objek tersebut bergerak atau dipindahkan dari posisi semula. (2) memiliki kemampuan spasial persepsi tentang susunan kubus sederhana maupun variatif, yaitu kemampuan untuk mengenal dan membedakan stimulus yang berkaitan dengan susunan kubus sederhana maupun variatif, dimana untuk menginterpretasikannya, stimulus tersebut dikaitkan dengan pengalaman masa lalu. Hal ini didukung oleh pendapat De Grade (1987) serta Frostig \& Horner (Saragih, 2011). Kemampuan spasial persepsi tentang susunan kubus 
sederhana maupun variatif ini terdiri dari: ketetapan perseptual (perceptual constancy), persepsi terhadap posisi dalam ruang (position in spatial perception), (c) Persepsi terhadap hubungan keruangan (Perception of spatial relationship), yaitu kemampuan untuk melihat dua atau lebih susunan kubus sederhana/variatif dan kaitannya satu sama lain. Kemampuan untuk menentukan banyak kubus dalam susunan kubus sederhana maupun variatif. (3) memiliki kemampuan spasial relasi, yaitu kemampuan untuk menyatakan kedudukan dua atau lebih kubus. Kemampuan yang berkaitan dengan hubungan kedudukan dua atau lebih kubus, seperti kubus mana yang berada pada posisi depan dan belakang, kubus mana yang berada dalam satu baris, kubus mana yang berhadapan, dan lain sebagainya (Elliot, 2005; De Guire dalam Saragih 2011). (4) memiliki kemampuan spasial orientasi, yaitu kemampuan untuk mengenal susunan atau bentuk kubus secara umum dengan membayangkan perubahan perspektif kubus. Kemampuan spasial orientasi merupakan kemampuan membayangkan (tanpa gambar) susunan kubus sederhana maupun variatif (Elliot, 2005; Kimura, 2005; De Guire dalam Saragih, 2011).

Persen skor rata-rata terendah siswa kelompok atas berturut-turut berada pada butir soal nomor 5, nomor $2 \mathrm{a}$, dan nomor $2 \mathrm{~b}$. Berdasarkan perolehan persen skor rata-rata butir soal nomor 5 dapat disimpulkan bahwa siswa kelompok atas: (1) tidak memiliki kemampuan spasial visual dalam kaitan menyelesaikan soal cerita kontekstual yang berkaitan dengan kubus. Tidak memiliki kemampuan untuk mengamati dan membayangkan penyelesaian soal cerita kontekstual yang berkaitan dengan kubus berdasarkan stimulus/rangsangan yang diberikannya. (2) tidak memiliki kemampuan spasial persepsi untuk menyelesaikan soal cerita kontekstual yang berkaitan dengan kubus. Ketidakmampuan untuk mengenal dan membedakan stimulus yang berkaitan dengan soal cerita kontekstual yang berhubungan dengan kubus, dimana untuk menginterpretasikannya, stimulus tersebut dikaitkan dengan pengalaman masa lalu. (3) tidak memiliki kemampuan spasial relasi, yaitu ketidakmampuan untuk menyatakan hubungan benda ruang kubus dalam soal cerita kontekstual. (4) tidak memiliki kemampuan spasial orientasi, yaitu ketidakmampuan untuk mengenal susunan atau bentuk kubus secara umum dengan membayangkan perubahan perspektif kubus. Kemampuan spasial orientasi merupakan kemampuan membayangkan (tanpa gambar) susunan kubus dalam soal cerita kontekstual.

Berdasarkan perolehan persen skor rata-rata butir soal nomor $2 \mathrm{a}$ dan $2 \mathrm{~b}$ dapat disimpulkan bahwa siswa kelompok atas: (1) tidak memiliki kemampuan spasial visual dalam kaitan menentukan banyak kubus pada gambar balok yang terbentuk dari susunan kubus tidak lengkap. Tidak memiliki kemampuan mengamati dan membayangkan untuk menentukan banyak kubus pada gambar balok yang terbentuk dari susunan kubus tidak lengkap berdasarkan stimulus/rangsangan yang diberikannya. (2) tidak memiliki kemampuan spasial persepsi untuk menentukan banyak kubus pada gambar balok yang terbentuk dari susunan kubus tidak lengkap. Ketidakmampuan untuk mengenal dan membedakan stimulus yang berkaitan dengan menentukan banyak kubus pada gambar balok yang terbentuk dari susunan kubus tidak lengkap, dimana untuk 
menginterpretasikannya, stimulus tersebut dikaitkan dengan pengalaman masa lalu. (3) tidak memiliki kemampuan spasial relasi, yaitu ketidakmampuan untuk menyatakan hubungan banyak kubus pada gambar balok yang terbentuk dari susunan kubus tidak lengkap dengan aspek-aspek keruangan.

Untuk siswa kelompok tengah persen skor tertinggi diperoleh pada butir soal nomor 1a sebesar 58,3\%, nomor 1 b sebesar 47,9\%, dan nomor 3a sebesar 58,3\%. Berdasarkan persen skor butir soal nomor 1a dan 1b dapat disimpulkan bahwa siswa kelompok tengah: (1) cukup memiliki kemampuan spasial visual untuk menentukan banyak kubus dalam balok yang tersusun dari kubus. Cukup mampu untuk mengamati dan membayangkan banyak kubus pada balok berdasarkan stimulus yang diberikannya. (2) cukup memiliki kemampuan spasial persepsi tentang banyak kubus dalam balok yang tersusun dari kubus. Cukup mampu untuk mengenal dan membedakan stimulus yang berkaitan dengan menentukan banyak kubus dalam balok yang tersusun dari kubus, dimana untuk menginterpretasikannya, stimulus tersebut dikaitkan dengan pengalaman masa lalu.

Persen skor terendah siswa kelompok tengah diperoleh pada butir soal nomor $4 \mathrm{a}$ sebesar 4,17\%, nomor 4 b sebesar $0,00 \%$, dan nomor 5 sebesar 5,2\%. Berdasarkan persen skor butir soal nomor $4 \mathrm{a}$ dan $4 \mathrm{~b}$ dapat disimpulkan siswa kelompok tengah: (1) tidak memiliki kemampuan spasial visual tentang susunan kubus variatif. Ketidakmampuan untuk mengamati dan membayangkan bentuk susunan kubus variatif berdasarkan stimulus yang diberikannya. (2) siswa kelompok tengah tidak memiliki kemampuan spasial persepsi tentang susunan kubus variatif. Ketidakmampuan untuk mengenal dan membedakan stimulus yang berkaitan dengan susunan kubus variatif.

Berdasarkan persen skor butir soal nomor 5 dapat disimpulkan bahwa siswa kelompok tengah: (1) tidak memiliki kemampuan spasial visual dalam kaitan menyelesaikan soal cerita kontekstual yang berkaitan dengan kubus. Tidak memiliki kemampuan untuk mengamati dan membayangkan penyelesaian soal cerita kontekstual yang berkaitan dengan kubus berdasarkan stimulus yang diberikannya. (2) tidak memiliki kemampuan spasial persepsi untuk menyelesaikan soal cerita kontekstual yang berkaitan dengan kubus.

Persen skor tertinggi siswa kelompok bawah diperoleh pada butir soal nomor 1a sebesar 25,0\%, nomor 3a sebesar 10,0\%, dan nomor 5 sebesar 10,0\%. Sedangkan untuk butir soal nomor 1b, 1c, 2a, 2b, 3b, 4a, dan 4b masing-masing memperoleh persen skor sebesar 0,0\%. Hasil ini menunjukan bahwa siswa kelompok bawah memiliki kemampuan keruangan yang sangat rendah bahkan dapat dikatakan tidak memiliki kemampuan keruangan sama sekali. Hasil-hasil tersebut juga menyimpulkan bahwa siswa kelompok bawah: (1) tidak memiliki kemampuan spasial visual untuk menentukan banyak kubus pada balok, baik sederhana maupun variatif, baik lengkap maupun tidak lengkap yang dilihat dari berbagai sisi. Tidak memiliki kemampuan spasial visual untuk menentukan penyelesaian soal cerita kontekstual yang berkaitan dengan memilih dua kotak (balok/kubus) mana yang lebih besar. (2) tidak memiliki kemampuan spasial persepsi untuk menentukan banyak kubus pada balok, baik 
sederhana maupun variatif, baik lengkap maupun tidak lengkap yang dilihat dari berbagai sisi. Tidak memiliki kemampuan spasial persepsi untuk menentukan penyelesaian soal cerita kontekstual yang berkaitan dengan memilih dua kotak (balok/kubus) mana yang lebih besar. Hal ini berarti pula siswa kelompok bawah tidak memiliki kemampuan ketetapan perseptual (perceptual constancy), yaitu ketidakmampuan mengenal bahwa untuk menentukan banyak kubus pada balok, baik sederhana maupun variatif, baik lengkap maupun tidak lengkap yang dilihat dari berbagai sisi, memiliki struktur yang jelas.

\subsubsection{Analisis Keterampilan Keruangan Berdasarkan Wawancara Klinis Berbasis Masalah}

Dari tiga orang siswa kelompok atas yang terpilih sebagai klien, didapatkan jawaban/respon positif tentang keterampilan dan kemampuan keruangan (spatial ability) yang mereka pahami. Jawaban positif berarti siswa memberikan jawaban berupa penjelasan sesuai pengetahuan atau penalaran yang mereka miliki. Sedangkan jawaban/respon negatif adalah jawaban/respon singkat yang diberikan siswa, seperti "Tidak tahu”, "Lupa”, "Tidak ingat" dan lain sebagainya atau jawaban lain yang tidak sesuai dengan indikator jawaban yang diharapkan. Dari jawaban klien siswa kelompok atas, terlihat bahwa siswa mencoba mengkonsepsi kembali bangun ruang kubus dengan cara membayangkan menurut pengalaman mereka. Walaupun jawaban ketiga siswa tidak sama persis dengan definisi formal kubus, namun dapat disimpulkan bahwa siswa kelompok atas memiliki keterampilan verbal dan kemampuan orientasi keruangan yang positif untuk menjelaskan bangun ruang kubus secara verbal.

Siswa kelompok tengah berjumlah 24 orang. Secara umum, dari siswa kelompok tengah didapatkan jawaban/respon yang bervariasi mengenai keterampilan keruangan siswa. Untuk beberapa keterampilan keruangan seperti keterampilan verbal dan keterampilan orientasi bernilai positif. Tetapi keterampilan logika, terapan dan persepsi terhadap ruang bernilai negatif.

Siswa kelompok bawah berjumlah 5 orang. Secara umum, dari tiga orang siswa kelompok bawah yang terpilih sebagai klien, didapatkan jawaban/respon yang negatif tentang keterampilan dan kemampuan keruangan (spatial ability). Siswa kelompok bawah tidak memiliki kemampuan dalam menentukan posisi dua rusuk pada kubus (keterampilan verbal, terapan, relasi) dan tidak mampu menentukan rumus volume kubus (keterampilan perseptual).

\section{Kesimpulan}

Dari hasil penelitian dan pembahasan maka dapat disimpulkan:

1. Keterampilan keruangan siswa mengenai kubus masih tergolong rendah. Siswa tidak memiliki konsep yang jelas tentang kubus atau kubus satuan. Hal ini menunjukan bahwa keterampilan visual siswa mengenai kubus atau susunan kubus masih rendah: Siswa tidak dapat mengidentifikasi fakta-fakta (melalui gambar) bahwa suatu gambar tersusun dari beberapa kubus, tidak dapat mengenali apakah suatu bangun ruang merupakan kubus atau bukan, apakah suatu bangun ruang terbentuk dari susunan 
kubus atau tidak. Keterampilan verbal siswa mengenai kubus atau kubus satuan masih rendah: Siswa tidak dapat menyebutkan definisi formal kubus/kubus satuan berdasarkan ciri, karakteristik dan gambar fisiknya, tidak dapat menjelaskan secara verbal (lisan/tulisan) keterkaitan kubus/kubus satuan satu terhadap lainnya, tidak mampu menjelaskan secara verbal (lisan/tulisan) keterkaitan konsep dan prinsip susunan bangun ruang yang terbentuk dari susunan kubus. Keterampilan logika siswa mengenai kubus atau kubus satuan masih rendah: Siswa tidak dapat mengidentifikasi kesamaan/perbedaan bangun ruang yang berkaitan dengan susunan kubus, tidak dapat mengidentifikasi sifat-sifat penting dari definisi, konsep, prinsip bangun ruang yang berkaitan dengan susunan kubus, tidak dapat mengidentifikasi implikasi logis dari informasi yang diberikan pada bangun ruang yang berkaitan dengan susunan kubus. Keterampilan terapan siswa mengenai kubus atau kubus satuan masih rendah: Siswa tidak dapat mengkonstruksi susunan kubus berdasarkan gambar objek fisiknya, tidak dapat menerapkan sifat-sifat geometri pada objek fisik kubus atau susunan kubus untuk menyelesaikan masalah.

2. Konsepsi siswa tidak sesuai dengan konsep yang terkait dengan penyelesaian masalah susunan kubus satuan. Hal ini berarti Siswa tidak mampu memanipulasi ideide terkait bahwa untuk menghitung banyak kubus. Siswa dapat menghitungnya melalui banyak kubus tiap lapisan kemudian menjumlahkannya. Siswa tidak mampu menyempurnakan hubungan konsep dan prinsip bahwa untuk menghitung banyak kubus siswa dapat mengaitkannya dengan konsep volume balok panjang $\mathrm{x}$ lebar $\mathrm{x}$ tinggi.

3. Konsepsi siswa tidak menunjukkan keterampilan yang terkait dengan penyelesaian masalah susunan kubus satuan. Hal ini menunjukkan bahwa: Siswa cenderung menggunakan pemahamannya sendiri untuk menyelesaikan masalah yang berkaitan dengan susunan kubus. Siswa secara intuitif menemukan penyelesaian masalah yang berkaitan dengan susunan kubus satuan. Siswa cenderung menebak untuk menemukan penyelesaian masalah yang berkaitan dengan susunan kubus satuan.

\section{Referensi}

Ambrose, R., dkk. (2003). Exploring The Use of Clinical Interviews in Teacher Development. American Educational Research Association. Chicago, IL.

Batista, M . T \& Clements, D. H. (1996). Student's Understanding of Threedimensional Rectangular Arrays of Cubes. Journal for Research in Mathematics Education, Vol. 27, No. 3.258-292.

Bishop, A.J. (1993). Spatial Abilities and Mathematics Education - a Review in Education Studies in Mathematics. D. Riedle Publishing Co. USA.

Black, A.A. (2005). Spatial Ability and Earth Science Conceptual Understanding. Springfield: Missioury State University. Tersedia: aab208f@smsu.edu [10 Januari 2012].

Brown, Nathaniel J. S. (2004). Performance Analysis: Characterizing Knowing In A Clinical Interview. San Diego: American Educational Research Association. 
Vol 1 No 22020 Desember 2020

Jurnal AlphaEuclidEdu

Caroll, J. B. (1993). Human Cognitive Abilities. A Survey of Factor Analytic Studies. New York: Cambridge University Press.

Christianti, Tarsila. (2012). Mengatasi Kesulitan Siswa Dalam Menyelesaikan Limit Fungsi Aljabar Menggunakan Wawancara Klinis Di Kelas XI SMA Benediktus Pahauman. Pontianak: Skripsi pada PS Pendidikan Matematika. STKIP PGRI.

Ginsburg, Herbert P. (2009). The Challenge of Formative Assessment in Mathematics Education: Children's Minds, Teachers' Minds. S. Karger AG, Basel.

Kemendikbud, (2016). Laporan Hasil Ujian Nasional SMP/MTs Tahun Pelajaran 2014/2015. Jakarta: Kemendikbud.

Mohler, J. L. (2008). A Review of Spatial Abilities Research. Engeneering Design Graphics Journal.

Moleong , Lexy J. (2009) Metodologi Penelitian Kualitatif. Bandung: Remaja Rosdakarya.

Moyer, Patricia dan Milewics, Elizabeth. (2002). Journal of Mathematics Teacher Education. Learning To Questions: Theoritical Perspective. Netherlands: Kluwer Academic Publishers.

National Council of Teachers of Mathematics. (2000). Principles and Standards for School Mathematics. Reston: VA NCTM.

Olkun, S. (2003). Making Connection: Improving Spatial Abilities with Engeneering Drawing Activities. International Journal of Mathematics Teaching and Learning.

Supinah. (2008). Pengaruh Strategi Pembelajaran dan Gaya Berpikir terhadap Hasil Belajar Matematika Siswa Eksperimen pada Siswa SMP di Daerah Istimewa Yogyakarta. Yogyakarta: Disertasi pada UNY.

Surya, Hendra. (2011), Strategi Jitu Mencapai Kesuksesan Belajar. Jakarta: Kompas Gramedia PT Elex Media Komputindo.

Wahyudin. (2003). Ensiklopedia Matematika untuk SLTP. Jakarta: CV Tarity Samudra Berlian. 
Vol 1 No 22020 Desember 2020

Jurnal AlphaEuclidEdu

Received: 25/11/2020; Revised: 30/11/2020; Accepted: 05/12/2020

\title{
IMPLEMENTASI SISTEM PEMBELAJARAN DARING BERBANTUAN EDMODO PADA MAHASISWA
}

\author{
Mirza, Ade \\ Dosen Pendidikan Matematika FKIP Universitas Tanjungpura Pontianak \\ Email: ade.mirza@fkip.untan.ac.id
}

\begin{abstract}
This research is a case study which aims to examine and describe the learning independence, learning outcomes, and student responses to the implementation of lectures with the edmodo-assisted online learning sistem. The subjects of this study were 142 students of the Mathematics education program FKIP Untan Pontianak in 2020 that who programmed the differential calculus course. This research activity in the process involves three senior students as collaborators (research assistants). Lecture practice is carried out by the lecturer who teaches these courses. This research procedure consists of: (1) reviewing the material, preparing research tools and instruments (developing and standardizing instruments). (2) Conducting lectures using the online learning sistem assisted by Edmodo. (3) Distributing questionnaires to obtain independence data, providing learning outcomes tests, and providing questionnaires to get student responses to the implementation of learning - (data collection). (4) Conduct studies and interpretations of the data obtained. (5) Reporting. The results of this study indicate that the learning independence of students in lectures is still not satisfactory. Student responses to the learning sistem were 57.04\% giving positive responses, and $42.96 \%$ giving negative responses. For learning outcomes, $74.65 \%$ were able to achieve a score $\geq 70$ and no one got a score less than 60 . In this case $57.75 \%$ got a $B$ grade and $16.90 \%$ got an A. It is clear that learning with the edmodo-assisted online sistem is able to make a fairly good contribution to differential calculus lectures.
\end{abstract}

Key words: Calculus, Independence learning, Mathematics.

\section{Pendahuluan}

Agenda utama dalam reformasi pendidikan Matematika dan Ilmu Pengetahuan Alam (MIPA) dewasa ini, di antarnya adalah penekanan pada pentingnya mengembangkan keterampilan berpikir tingkat tinggi mahasiswa calon guru. Upaya pengembangan kapasitas intelektual tersebut dimaksudkan agar mereka siap dihadapkan pada transisi pengetahuan dan arus informasi yang semakin deras serta mampu beradaptasi dan menyerap informasi yang dibutuhkan (AACTE, 2010). Sejalan dengan hal ini, sejumlah laporan nasional di berbagai negara dalam kurun waktu 20 tahun terakhir telah menunjukkan bahwa desain pembelajaran untuk menstimulasi proses berpikir dan pemecahan masalah serta menghasilkan solusi yang kompleks menjadi sangat dibutuhkan (Halpern, 2003; Zohar, Degani \& Vaaknin, 2001; Moseley, et.all, 2005), 
Vol 1 No 22020 Desember 2020

Jurnal AlphaEuclidEdu

Received: 25/11/2020; Revised: 30/11/2020; Accepted: 05/12/2020

agar pemelajar mampu beradaptasi terhadap setiap perubahan (Halpern, 2003), memperoleh pengetahuan baru secara lebih cepat, dan menghadapi kompleksitas permasalahan nyata di dalam kehidupan (King, Goodson \& Rohani, 2006).

Diakui bahwa, matematika merupakan salah satu subyek pengetahuan yang penting dalam kehidupan manusia dan merupakan body dari sains dan teknologi (Acharya, 2017). Kalkulus misalnya, merupakan salah satu mata kuliah dasar yang sangat penting bagi mahasiswa matematika di universitas. Namun demikian, masih banyak pemelajar (mahasiswa) yang tidak dapat mencapai pemahaman ataupun pengertian yang mendalam (understanding to), dan bahkan kalkulus dianggap sebagai pelajaran (mata kuliah) yang sangat sulit untuk dipelajari, membosankan, dan subjek yang abstrak (Zhang, 2003; Zhou, 2002). Mudah frustasi dalam menghadapi masalah, tidak mengerti makna symbol yang digunakan, dan tidak cermat memanifulasi variabel x yang berupa penyebut (Mirza, 2019).

Untuk dapat menghasilkan guru yang profesional, institusi pendidik calon guru perlu membekali mahasiswa dengan berbagai teori, metode, dan keterampilan. Sementara itu, sekolah menyediakan kelas dan kurikulum, serta calon guru sendiri harus melakukan usaha individual. Lembaga Pendidikan Tenaga Kependidikan (LPTK) sebagai penghasil sarjana pendidikan tentu memiliki andil besar dalam melahirkan calon guru-guru berkualitas. Guru yang berkualitas adalah guru yang memiliki berbagai kompetensi untuk menjalankan dan melaksanakan tugasnya sebagai pendidik. Untuk itu, LPTK harus selektif dalam melaksanakan perannya sebagai filter penghasil calon guru, dengan mendorong sistem perkuliahan yang dapat meningkatkan kapasitas keterampilan profesional termasuk keterampilan berpikir tingkat tinggi (Higher Order Thinking Skills - HOTS).

Fokus pengembangan kompetensi pembelajaran matematika menghadapi abad 21 ini lebih ditekankan pada kecakapan matematis yang mencakup pemahaman konsep, kelancaran prosedur, dan pemecahan masalah serta pada keterampilan proses (daya matematis) yang mencakup kemampuan penalaran, komunikasi, koneksi, representasi dan proses pemecahan masalah (NCTM, 2000; Toh \& Kaur, 2016).

Pada kenyataannya, sistem perkuliahan atau proses pembelajaran yang dilakukan untuk membina mahasiswa calon guru matematika pada program studi pendidikan 
Vol 1 No 22020 Desember 2020

Jurnal AlphaEuclidEdu

Received: 25/11/2020; Revised: 30/11/2020; Accepted: 05/12/2020

matematika FKIP Untan masih cenderung dilakukan secara konvensional yaitu dengan pembelajaran tatap muka di dalam kelas. Dengan sistem pembelajaran seperti itu, ketika dosen tidak bisa hadir di kampus maka kegiatan pembelajaran tidak dapat dilaksanakan, ataupun ketika seorang mahasiswa berada di luar kampus maka mahasiswa tersebut tidak dapat mengikuti kegiatan pembelajaran. Sistem informasi pembelajaran online yang tersedia hanya dimanfaatkan dalam rangka untuk menyampaikan tugas dan materi pembelajaran yang perlu dipelajari secara mandiri.

Munculnya kasus Covid-19 yang terjadi memasuki awal tahun 2020 sekarang ini, membuat banyak perubahan baik di tingkat internasional maupun di tingkat nasional, bahkan lokal. Khusus di bidang pendidikan, Menteri Pendidikan dan Kebudayaan Republik Indonesia telah mengeluarkan instruksi dalam rangka Pencegahan virus Corona di Satuan Pendidikan, di antaranya dengan mengeluarkan Surat Edaran Nomor 36962/MPK.A/HK/2020 agar seluruh kegiatan belajar mengajar baik di sekolah maupun kampus perguruan tinggi menggunakan moda daring (dalam jaringan) alias online. Hal ini dimaksudkan sebagai upaya pencegahan terhadap perkembangan dan penyebaran Coronavirus disease (Covid-19). Untuk itu, beberapa lembaga pendidikan termasuk program studi pendidikan matematika FKIP Untan Pontianak harus melakukan antisipasi terhadap penyebaran virus ini dengan menyelenggarakan kuliah jarak jauh berbentuk 'online learning' atau 'belajar dalam jaringan' (belajar daring) dan berbantuan edmodo.

Pembelajaran sistem daring ini sebenarnya bukanlah hal baru. Banyak program aplikasi yang berbasis Learning Management System (LMS) yang telah dikembangkan untuk keperluan pendidikan/pembelajaran dan bahkan gratis seperti google meet, edmodo, dan lain-lain. Apalagi saat ini, perkembangan teknologi dan informasi semakin pesat. Kemajuan teknologi dalam sistem informasi melalui dunia digital seperti internet semakin mempermudah setiap orang dalam mengakses berbagai persoalan dan fenomena yang terjadi di dunia. Hal ini tentu membutuhkan kemandirian dari pemelajar dalam belajarnya. Namun demikian, realitas di lapangan menunjukkan bahwa proses pembelajaran yang memanfaatkan fasilitas teknologi tersebut belum banyak dilakukan. Akibatnya, timbul berbagai persoalan yang dihadapi ketika proses pembelajaran memaksa untuk menggunakan sistem online (sistem daring). 
Vol 1 No 22020 Desember 2020

Jurnal AlphaEuclidEdu

Received: 25/11/2020; Revised: 30/11/2020; Accepted: 05/12/2020

Pembelajaran dalam jaringan dapat digunakan sebagai alternatif solusi ketika kegiatan pembelajaran tatap muka tidak dapat dilaksanakan sebagaimana mestinya. Pembelajaran dalam jaringan dapat dilakukan melalui aktivitas belajar synchronous misalnya melalui video-converencellive-chat, ataupun secara asynchronous melalui kegiatan pembelajaran yang telah dirancang dalam sistem pembelajaran online (Tafqihan, 2011).

Substansi pembelajaran yang disampaikan dalam sistem jaringan harus sesuai dengan substansi pembelajaran tatap muka, seperti tujuan pembelajaran, konten, kesesuaian dengan kurikulum dan silabus dan perancangan pembelajaran. Untuk itu, perlu dikembangkan suatu sistem pembelajaran yang dapat mengakomodasi kegiatan pembelajaran sistem daring tanpa mengurangi substansi pembelajaran tatap muka. Materi yang akan disampaikan dengan moda daring harus sesuai dengan materi yang disampaikan dengan sistem tatap muka. Selain itu, media pembelajaran sistem daring juga harus bisa memfasilitasi mahasiswa untuk terlibat aktif dalam membangun pengetahuannya melalui forum diskusi. Pada akhirnya, evaluasi pelaksanaan pembelajaran juga dapat diukur dengan assessment yang sesuai.

Memperhatikan hal-hal yang telah diuraikan, perlu pengkajian lebih lanjut mengenai dampak dari pelaksanaan pembelajaran/perkuliahan dengan sistem daring berbantuan edmodo yang dilakukan pada program studi pendidikan matematika FKIP Untan Pontianak. Penelitian ini dilakukan dengan tujuan untuk mengetahui dan mendeskripsikan efek dari pelaksanaan pembelajaran dengan sistem daring berbantuan edmodo terhadap kemandirian belajar dan hasil belajar mahasiswa program studi pendidikan matematika FKIP Untan, serta mengetahui respon mahasiswa terhadap pelaksanaan sistem pembelajaran tersebut.

Melalui penelitian ini diharapkan dapat diketahui kebutuhan belajar mahasiswa dalam sistem pembelajaran daring berbantuan edmodo. Selanjutnya, temuan ini dapat dijadikan sebagai bahan kajian untuk mengembangkan model pembelajaran daring berbantuan edmodo yang efektif dan dapat mendukung kelancaran dalam proses perkuliahan mahasiswa pada program studi pendidikan matematika FKIP Untan Pontianak. 
Vol 1 No 22020 Desember 2020

Jurnal AlphaEuclidEdu

Received: 25/11/2020; Revised: 30/11/2020; Accepted: 05/12/2020

\section{Metode Penelitian}

Seperti telah diungkapkan di bagian pendahuluan bahwa tujuan penelitian ini adalah untuk mengkaji dan mendeskripsikan efek dari penerapan sistem pembelajaran daring berbantuan edmodo pada mahasiswa program studi pendidikan matematika FKIP Untan pada semester genap tahun akademik 2019/2020. Fokus penelitian ini adalah mengkaji: (1) Apakah sistem pembelajaran daring berbantuan edmodo dapat meningkatkan kemandirian belajar mahasiswa? (2) Apakah sistem pembelajaran daring berbantuan edmodo dapat meningkatkan hasil belajar mahasiswa? Dan (3) Bagaimana respon mahasiswa program studi pendidikan matematika FKIP Untan terhadap pelaksanaan perkuliahan dengan sistem pembelajaran daring berbantuan edmodo?

Karena itu, penelitian ini dapat dikategorikan sebagai studi kasus yang bersifat deskriptif (Arikunto, 2010; Bogdan \& Biklen, 2007), yakni bermaksud mengetahui keadaan mengenai kemandirian belajar, hasil belajar, dan respon mahasiswa pada program studi pendidikan matematika FKIP Untan mengenai pelaksanaan perkuliahan dengan sistem pembelajaran daring berbantuan edmodo. Subyek penelitian ini melibatkan 142 mahasiswa program studi pendidikan matematika yang memprogramkan mata kuliah kalkulus diferensial tahun akademik 2019/2020.

Prosedur penelitian ini terdiri dari lima tahapan. Tahap pertama: mengkaji materi, mempersiapkan alat dan instrumen penelitian (pengembangan dan pembakuan instrumen). Tahap kedua: Melaksanakan pembelajaran dengan sistem daring berbantuan edmodo. Tahap ketiga: Menyebarkan kuesioner, memberikan tes hasil belajar, dan Memberikan angket untuk mendapatkan respon mahasiswa terhadap pembelajaran yang dilakukan. (pengambilan data). Tahap keempat: Melakukan kajian dan interpretasi terhadap data yang diperoleh. Tahap kelima: Tahap pelaporan. Kegiatan penelitian ini dalam prosesnya melibatkan tiga orang mahasiswa sebagai kolaborator (pembantu peneliti), dan lima orang dosen pendidikan matematika FKIP Untan yang bertindak sebagai validator terhadap instrumen penelitian yang digunakan.

Untuk mendapatkan data mengenai kemandirian belajar dilakukan dengan menggunakan kuesioner. Indikator yang digunakan untuk mendapatkan data ini mencakup kebutuhan belajar, yang meliputi kesulitan belajar yang dialami, bahan yang dipelajari, usaha yang dilakukan, bantuan belajar yang digunakan, frekwensi melakukan 
Vol 1 No 22020 Desember 2020

Jurnal AlphaEuclidEdu

Received: 25/11/2020; Revised: 30/11/2020; Accepted: 05/12/2020

kegiatan belajar, waktu yang digunakan untuk belajar, jenis bahan ajar pendukung yang digunakan, dan kebutuhan lainnya yang diperlukan mahasiswa.

Data hasil belajar diperoleh dari nilai yang diberikan oleh dosen mata kuliah kalkulus diferensial. Sedangkan data respon didapatkan melalui angket berupa tes dengan skala likert yang terkait dengan sikap, persepsi, perasaan dan pendapat mereka mengenai pembelajaran sistem daring berbantuan edmodo.

Data dalam penelitian ini terdiri dari data kualitatif (data kemandirian belajar), dan data kuantitatif (hasil belajar dan respon). Analisis data kualitatif dijabarkan dengan kata-kata yang disusun dan disajikan dalam bentuk teks naratif. Sedangkan data kuantitatif yang diperoleh dari angket (berupa respon/tanggapan mahasiswa), diolah dengan menggunakan analisis skala Likert. Selanjut, untuk hasil belajar akan dideskripsikan dengan menggunakan persentase dan diagram batang.

\section{Hasil dan Pembahasan}

Setelah melaksanakan proses pembelajaran (perkuliahan) untuk mata kuliah kalkulus diferensial pada empat kelas, yakni kelas A1, A2, A3, dan kelas B dengan menggunakan sistem daring dan berbantuan edmodo, diperoleh hasil sebagai berikut.

\subsection{Kemandirian Belajar}

Paradigma belajar saat ini telah mengalami perubahan yang signifikan. Proses belajar tidak lagi harus dilakukan dan berlangsung dalan ruang dan waktu tertentu dan disertai kehadiran dosen. Perkembangan ilmu pengetahuan dan teknologi telah membawa sistem belajar mandiri (kemandirian belajar) sebagai kebutuhan individu untuk meningkatkan pengetahuan/keterampilan yang diperlukan. Sistem belajar mandiri ini merupakan alternatif sistem pendidikan yang bersifat luwes dengan kegiatannya dapat fleksibel (Ravet dan Laytee, 1997). Penerapan konsep belajar mandiri tidak berarti mengharuskan pemelajar untuk belajar sendiri, tetapi belajar secara terstruktur dengan menggunakan bahan ajar (learning materials) yang telah dirancang untuk keperluan tersebut. Bahan ajar ini merupakan medium yang digunakan untuk menyampaikan materi perkuliahan kepada mereka. Aktivitas belajar mandiri ini memiliki kaitan yang erat dengan pengendalian kegiatan belajar yang dilakukan oleh 
Vol 1 No 22020 Desember 2020

Jurnal AlphaEuclidEdu

Received: 25/11/2020; Revised: 30/11/2020; Accepted: 05/12/2020

individu (mahasiswa) itu sendiri, yakni pembelajaran yang berpusat pada pemelajar/peserta didik (France \& Jordan, 2000).

Dari data yang diperoleh, kemandirian belajar 142 mahasiswa dalam perkuliahan kalkulus diferensial masih belum memuaskan, karena:

a) Mahasiswa umumnya tidak terbiasa belajar sebelum mengikuti perkuliahan

b) Mahasiswa memiliki frekwensi belajar yang relatif rendah dalam mempelajari mata kuliah kalkulus diferensial, dan tidak terbiasa memanfaatkan sumber belajar lain selain buku/bahan ajar yang diberikan

c) Mahasiswa pada umumnya kurang berusaha untuk mencari sumber belajar lain selain dari buku/bahan ajar yang diberikan untuk menambah dan mengembangkan pengetahuan serta keterampilannya.

d) Mahasiswa mengemukakan bahwa mereka jarang mendapat umpan balik yang memberikan penjelasan tentang hasil belajar yang diperoleh.

\subsection{Hasil Belajar}

Hasil belajar mahasiswa berdasarkan nilai akhir mata kuliah yang diperoleh dari rekap sistem akademik di FKIP Untan (Siakad) menunjukan Kelas A1 (nilai A=12 orang, $\mathrm{B}=12$ orang, $\mathrm{C}=3$ orang); Kelas $\mathrm{A} 2$ (nilai $\mathrm{A}=2$ orang, $\mathrm{B}=33$ orang, $\mathrm{C}=11$ orang), Kelas $\mathrm{A} 3$ (nilai $\mathrm{A}=9$ orang, $\mathrm{B}=9$ orang, $\mathrm{c}=2$ orang) dan Kelas $\mathrm{B}$ (nilai $\mathrm{A}=1$ orang, $\mathrm{B}=28$ orang, $\mathrm{C}=20$ orang). Jadi secara keseluruhan, yang mendapat nilai $\mathrm{A}=24$ orang, nilai $\mathrm{B}=82$ orang, dan nilai $\mathrm{C}=36$ orang. Frekwensi dari 142 mahasiswa berdasarkan perolehan hasil belajar ini dapat digambarkan dalam bentuk diagram batang sebagai berikut.

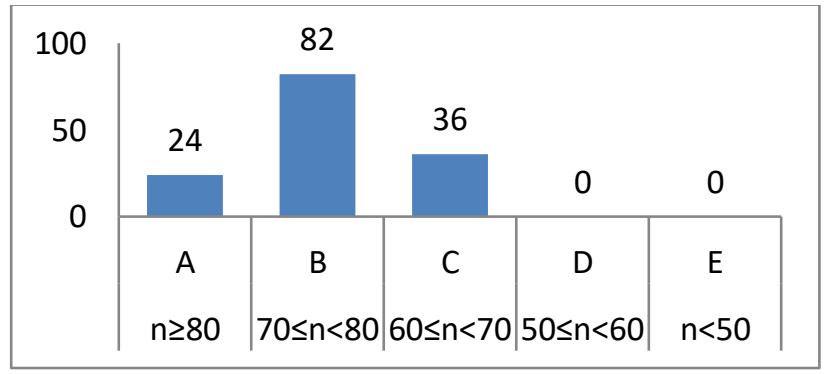

Gambar 4.1. Frekwensi Mahasiswa Berdasarkan Perolehan Hasil Belajar

3.3. Respon Mahasiswa 
Vol 1 No 22020 Desember 2020

Jurnal AlphaEuclidEdu

Received: 25/11/2020; Revised: 30/11/2020; Accepted: 05/12/2020

Respon Mahasiswa terhadap pembelajaran, berdasarkan jawaban dari 25 item angket respon setelah dilakukan pembobotan, diperoleh jumlah skor dan skor rata-rata dari masing-masing responden. Berdasarkan data ini selanjutnya dihitung frekwensi dan persentase respon untuk mendapatkan table interval respon yang dijadikan sebagai indikator respon mahasiswa terhadap sistem pembelajaran daring berbantuan edmodo yang dilakukan dalam penelitian ini. Berdasarkan data tersebut, 81 orang mahasiswa $(57,04 \%)$ memberikan respon positip, dan 61 (42,96\%) memberikan respon negatip.

Kriteria yang digunakan untuk menentukan kategori respons mahasiswa terhadap sistem pembelajaran daring berbantuan edmodo pada mata kuliah kalkulus diferensial dalam penelitian ini adalah mengacu pada tabel interval dari skala sikap/persepsi sebagai berikut.

Tabel 4.1.

Interval Skor Respon Mahasiswa Terhadap Perkuliahan Dengan

Sistem Pembelajaran Daring Berbantuan Edmodo

\begin{tabular}{|c|c|}
\hline Interval & Respon \\
\hline $0,00-0,45$ & Sangat Negatif \\
\hline $0,46-1,33$ & Negatif \\
\hline $1,34-2,19$ & Positif \\
\hline $2,20-2,70$ & Sangat Positif \\
\hline
\end{tabular}

Hasil tersebut menunjukkan bahwa persentase respon mahasiswa terhadap perkuliahan sistem daring berbantuan edmodo setelah dilakukan pembobotan skor butir respon masih cukup berimbang. Walaupun secara kuantitas, respon mahasiswa menunjukkan respon yang positip, namun hal ini masih kurang memuaskan karena tidak ada yang memberikan respon yang "sangat positif". Sebaliknya sistem perkuliahan tersebut tidak juga memberikan respon yang tidak baik, karena tidak ada yang memberikan respon "sangat negatip". Dengan demikian, model perkuliahan dengan sistem daring dan berbantuan edmodo masih dapat diterima sebagian besar mahasiswa.

Terkait dengan respon negatip yang diberikan mahasiswa, tampaknya lebih dominan diakibatkan karena adanya gangguan atau hambatan lain yang bersifat non teknis pembelajaran. Gangguan atau hambatan tersebut seperti perlunya biaya pembelian fulsa/quota internet, jaringan internet yang tidak mendukung, dan aliran listrik yang terganggu (mati), serta ada juga yang terhambat karena persoalan perangkat yang tidak memadai. Hal ini membuat mahasiswa menjadi bingung, kecewa dan membebaninya. 
Vol 1 No 22020 Desember 2020

Jurnal AlphaEuclidEdu

Received: 25/11/2020; Revised: 30/11/2020; Accepted: 05/12/2020

\subsection{Tantangan Yang Dihadapi Dalam Pembelajaran Sistem Daring}

Ada berbagai pandangan mengenai pengertian belajar dalam jaringan (daring). Dalam Kamus Besar Bahasa Indonesia, Daring diartikan dalam jaringan, terhubung melalui jejaring computer, internet dan sebagainya. Menurut Sutrisno (2020), rangkuman sistematis tentang pengertian belajar dalam jaringan telah dibuat oleh Vandana Singh dan Alexander Thurman pada tahun 2019. Hasil analisis isi (content analysis) yang dilakukan mereka tentang definisi belajar dalam jaringan yang digunakan dalam kurun waktu 1988-2018 menemukan ada 37 rumusan yang saling berbeda. Di sini, perbedaan rumusan tersebut tidak perlu diperdebatkan. Akan tetapi, yang penting diperhatikan adalah sisi positipnya saja, apapun bentuk atau sistem pembelajaran daring yang digunakan. Lebih lanjut Sutrisno (2020) menyatakan bahwa Universitas Purdue Internasional mengungkap empat tantangan yang umum dihadapi oleh para pemelajar dalam jaringan, terutama bagi mereka yang belum terbiasa atau belum ernah bekerja dalam jaringan. Tantangan-tantangan itu adalah sebagai berikut: (1) literasi digital, (2) masalah teknis, (3) pengelolaan waktu, dan (4) motivasi.

Tantangan 1 : literasi digital

Untuk mengikuti kelas daring, diperlukan kemampuan menggunakan teknologi yang memadai untuk: ' $\log$ in', berpartisipasi, berkomunikasi dalam kelas dan menyerahkan tugas. Kemampuan ini mencakup pemahaman etika komunikasi dalam jaringan serta pengetahuan tentang hak dan kewajibannya sebagai pembelajar dalam jaringan. Untuk menangani tantangan itu disarankan agar memperhatikan sungguh-sungguh apa yang dikehendaki instructor/dosen tentang apa yang harus dilakukan. Ada beberapa yang perlu diingat tentang etika berkomunikasi dalam jaringan, seperti menghindari penggunaan kata sakartik (kasar), komentar dan pertanyaan yang tidak relevan.

Tantangan 2 : masalah teknis

Sebagai pemelajar dalam jaringan, hanya akan berhasil jika berhasil terhubung kapan pun dan dimana pun. Karena itu, mesti tersedia kuota dan koneksi internet yang kuat (memadai). Masalah ini tidak semua orang mampu menyelesaikan karena berkaitan dengan dana yang tersedia.

Tantangan 3 : pengelolaan waktu

Pembelajaran secara daring membutuhkan kesadaran individu untuk mau mengatur waktu dalam beraktivitas. Kelemahan dalam mengelola atau mengatur waktu secara 
Vol 1 No 22020 Desember 2020

Jurnal AlphaEuclidEdu

Received: 25/11/2020; Revised: 30/11/2020; Accepted: 05/12/2020

baik dapat menjadi sebab yang membebani dalam melaksanakan tugas belajar yang diberikan.

Tantangan 4 : kedisiplinan dan motivasi

Belajar daring perlu motivasi diri yang kuat untuk dapat menyelesaikan tugas tepat waktu. Akibat tidak ada interaksi (tidak berkumpul) dengan rekan-rekan sekelas secara fisik, seringkali memunculkan godaan pada diri untuk menunda pekerjaan.

\section{Kesimpulan}

Berdasarkan data yang diperloleh dari hasil penelitian ini, maka dapat dibuat kesimpulan sebagai berikut:

1) Kemandirian belajar

Terkait dengan kemandirian belajar, dapat disimpulkan bahwa para mahasiswa umumnya tidak terbiasa untuk belajar (mempelajari materi) sebelum mengikuti program perkuliahan. Frekwensi belajar yang dilakukan mahasiswa masih rendah. Masih banyak mahasiswa yang tidak memanfaatkan sumber belajar lainnya selain bahan ajar atau materi yang diberikan dosen, untuk menambah wawasan pengetahuan dan keterampilannya agar mencapai kemampuan/keterampilan berpikir tingkat tinggi (higher order thinking skills).

Mahasiswa lebih cenderung memerlukan pengetahuan yang bersifat praktis agar dapat digunakan dalam menyelesaikan masalah/soal yang terkait materi yang dipelajari. Dalam hal ini, mereka umunya kurang serius untuk memahami hal-hal yang bersifat analitis, sehingga mereka mengganggap buku-buku atau referensi yang tersedia sangat bersifat teoritis.

2) Hasil Belajar

Berdasarkan data hasil belajar 142 mahasiswa yang menjadi subyek penelitian, didapatkan bahwa 74,65\% mahasiswa mampu mencapai skor $\geq 70$, yakni : 57,75\% mendapat nilai B dan 16,90\% mendapat nilai A. Sisanya, Nilai C 25,3\%, sedangkan nilai $\mathrm{D}$ dan $\mathrm{E}$ tidak ada. Data ini menunjukkan bahwa pembelajaran dengan sistem daring berbantuan edmodo ternyata masih mampu memberikan kontribusi yang cukup baik bagi keberhasilan mahasiswa dalam mengikuti dan menguasai materi perkuliahan kalkulus diferensial.

3) Respon Mahasiswa 
Vol 1 No 22020 Desember 2020

Jurnal AlphaEuclidEdu

Received: 25/11/2020; Revised: 30/11/2020; Accepted: 05/12/2020

Berdasarkan data 142 mahasiswa yang dijadikan subyek analisis dalam penelitian ini, diperoleh: 81 orang $(57,04 \%)$ memberikan respon positip terhadap sistem perkuliahan daring berbantuan edmodo, sisanya 61 orang $(42,96 \%)$ memberikan respon yang negatif, dan tidak ada responden yang memberikan respon untuk kategori sangat negatif ataupun sangat positip. Hal ini menunjukkan bahwa pembelajaran sistem daring berbantuan edmodo masih dianggap cukup baik. Namun demikian, ada tantangan yang harus dihadapi dan diantisipasi ketika berhadapan dengan sistem pembelajaran daring, yakni tantangan literasi digital, masalah teknis, pengelolaan waktu, dan (4) motivasi.

Kiranya, pengkajian yang lebih mendalam untuk masalah penelitian semacam ini masih perlu dilakukan untuk mendapatkan data dan informasi yang lebih akurat. Selanjutnya, perlu dikembangkan desain perkuliahan (desain pedagogik) yang dapat memfasilitasi belajar mahasiswa dengan sistem daring yang lebih berkualitas dan mudah dilakukan agar tercipta kualitas proses perkuliahan maupun kualitas kompetensi profesional dan pedagogik pada diri mahasiswa, khususnya pada mahasiswa pendidikan matematika di lingkungan FKIP Untan.

\section{Referensi}

AACTE. (2010). 21 ${ }^{\text {st }}$ Century knowledge and skills an educator preparation. The American Association of Colleges of Teacher Education and the Partnership for $21^{\text {st }}$ Century Skills (P21). http://www.p21.org/storage/documents/ aacte_p21_whitepaper2010.pdf. Diakses 9 Februari 2015

Acharya, B. R. (2017). Factors Affecting Difficulties in Learning Mathematics by Mathematics Learners. International Journal of Elementary Education, 815.

Arikunto, S. (2010). Prosedur Penelitian: Suatu Pendekatan Praktek, Edisi Revisi. Jakarta: Rineka Cipta.

Bersin, J. (2011). Blended learning: Research reports \& examples of best practices. Estonia: B-Learn Project University of Tartu.

Bogdan, R.C. \& Biklen, S.K. (2007). Qualitative Research for Education: An Introduction to Theory and Methods $5^{\text {th }}$.ed. Boston: Allyn \& Bacon.

France, B \& Jordan, D.H. (2000). Evaluation and Implementation of Distance Learning: Technologies, Tools and Technique. UK: Idea Group Publishing.

Halpern, D. F. (2003). Thought and knowledge: An introduction to critical thinking (4 ${ }^{\text {nd }}$ Edition). New Jersey: Lawrence Erlbaum Associates Publisher

King, F. J., Goodson, L., \& Rohani. (2006). Higher order thinking skills. Center for Advancement of Learning and Assessment.

Mirza, Ade. (2019). Hambatan Belajar Mahasiswa Program Studi Pendidikan Matematika FKIP Untan Dalam Mata Kuliah Kalkulus Diferensial. Laporan Penelitian. Pontianak: FKIP Untan. 
Vol 1 No 22020 Desember 2020

Jurnal AlphaEuclidEdu

Received: 25/11/2020; Revised: 30/11/2020; Accepted: 05/12/2020

Moseley, D., Baumfield, V., Elliot, J., Gregson, M., Higgins, S., Miller, J., \& Newton, D. (2005). Frameworks for thinking: A handbook for teaching and learning. New York: Cambridge University Press.

National Council of Teacher of Mathematics (NCTM). (2000). Principles and Standards for School Mathematics. Reston, VA: NCTM.

Ravet, S. \& Laytee, M. (1997). Technology-Based Training: A Comprehensive Guide to Choosing, Implementing, Managing, and Developing Technologies in Training.

Sutrisno, L. (2020). Belajar dalam Jaringan. https://teraju.id/opini/darurat-pembelajarandalam-jaringan-di-perguruan-tinggi-12716/ diakses tgl 14 Maret 2020.

Tafqihan, Z. (2011). Karakteristik dan Pemilihan Media Pembelajaran dalam ELearning. Jurnal Cendekia Volume 2 Nomor 9 tahun 2011, hal: 141154,ISSN: 2477-796X.

Toh P. Choon \& Kaur, B. (2016). Developing 21st Century Competencies In The Mathematics Classroom. Yearbook 2016, Association of Mathematics Educators. Singapore: World Scientific Publishing Co. Pte. Ltd.

Zhang, B. (2003). Using student centered teaching strategis in calculus. In M. Peat (ed.) The China Papers: Tertiary Science and Mathematics Teaching for the 21st Century, 2: 100-103.

Zhou Yuan, (2002). Improving the qualities of teaching calculus - by modern education theories and modern technology, In M. Peat (ed.) The China Papers: Tertiary Science and Mathematics Teaching for the 21st Century, 1: 23-27.

Zohar, A., Degani, A \& Vaaknin, E. (2001). Teachers' beliefs about low-achieving students and higher order thinking. Teaching and Teacher Education, 17: 469485 
Vol 1 No 22020 Desember 2020

Jurnal AlphaEuclidEdu

Received: 21/10/2020; Revised: 28/11/2020; Accepted: 05/12/2020

\title{
PENGEMBANGAN INSTRUMEN EKSPLORASI KONSEP GEOMETRI BERSTRUKTUR DARI TEORI VAN HIELE BERBANTUAN SOFTWARE GEOGEBRA
}

\author{
${ }^{1}$ Pratikna, Dominicus Savio, ${ }^{2}$ Sugiatno, ${ }^{3}$ Hartoyo, Agung \\ 1,2,3 Pendidikan Matematika FKIP Universitas Tanjungpura Pontianak \\ Email:13savio@gmail.com
}

\begin{abstract}
The purpose of this study was to analyze the requirements of instrument, the characteristics of the developed questions prototype, the feasibility of the questions, and the thinking level of students regarding Van Hiele's Theory of geometry concept taught with assistance of Geogebra Software. This study was a Research and Development using Wina Sanjaya's model. The instrument' development procedure consists of four stages, namely: Preliminary Stage, Product Development Stage; Stage of Trial and Product Validation and Dissimination Stage of products. The instrument feasibility is based on the accuracy and practicality test. The subjects of this study were all students of class XI Santu Petrus Pontianak 2016/2017 Academic Year, with a sample of class XI-MIA3 students chosen randomly. The results showed the level of instrument feastibility which expressed through experts' testing and student' opinions, calculation of validity, reliability, distinguishing factors, levels of difficulty, and practicality test results. The instrument obtained an average validity of 0.68 belongs to high category, a reliability of 0.998 belongs to very high category, and a difficulty level of 0.35 belongs to moderate category. The percentage of content validity, construction and language content rated by the experts amounted to $91.16 \%$, which categorized as high. The student response rate was $80.9 \%$ which belong to good category.

Keywords: Instruments, Van Hiele's theory, Geogebra Software
\end{abstract}

\section{Pendahuluan}

Menurut Van De Walle (2008:149) bahwa pentingnya geometri untuk dipelajari, antara lain yaitu eksplorasi geometri memainkan peranan utama dalam bidang matematika lain dan digunakan banyak orang dalam kehidupan serta mempunyai tantangan dan menarik. Kennedy (2008:390) menyatakan bahwa pengetahuan, keterampilan geometri, kemampuan spasial, dan memecahkan masalah siswa dapat dikembangkan dengan mempelajari geometri. Dalam mempelajari geometri di sekolah perlu dikembangkan instrumen pembelajaran geometri yang mampu merangsang siswa untuk mencari sendiri, melakukan eksplorasi sendiri, melakukan pembuktian terhadap suatu dugaan yang mereka buat sendiri dan mencari tahu jawaban atas pertanyaan teman atau pertanyaan gurunya (Turmudi, 2008:25).

Dari pengamatan penulis pada umumnya pembelajaran dan instrumen tes geometri di kelas lebih bersifat konvensional dan kurang memberikan kesempatan luas kepada siswa untuk mengeksplorasi dan menemukan sendiri konsep-konsep geometri. Salah satu sebabnya belum tersedia materi pembelajaran dan instrumen yang memfasilitasi siswa bereksplorasi, serta terbatasnya pemakaian media pembelajaran berbasis teknologi untuk mempermudah proses bereksplorasi tersebut. Oleh karena konsepkonsep geometri sangat penting untuk dipelajari maka perencanaan pembelajaran 
Vol 1 No 22020 Desember 2020

Jurnal AlphaEuclidEdu

geometri perlu dirancang sebaik mungkin dengan memanfaatkan media pembelajaran dan instrumen geometri yang berbasis teknologi.

Pembelajaran dan pengembangan instrumen geometri berbasis teknologi ideal dimanfaatkan dalam mengeksplorasi konsep-konsep geometri. Dalam mengeksplorasi konsep-konsep geometri, perlu ketersediaan instrumen yang mampu mengeksplorasi konsep-konsep geometri. Instrumen tersebut disajikan secara terstruktur dan memerlukan tampilan grafis dengan ketepatan yang sangat baik dan cepat. Software Geogebra adalah Salah satu media yang berbasis teknologi. Sarana pada software Geogebra mendukung untuk mengaktifkan siswa mengeksplorasi konsep geometri dan meningkatkan pemahaman konsep geometri dengan baik. Penerapan software Geogebra pada pembelajaran dan pengembangan instrumen seiring dengan prinsip teknologi dari dokumen NCTM (2000: 24-27).

Dalam dokumen NCTM (2000: 24-27) dikembangkan bahwa peran teknologi sangat penting dalam pembelajaran matematika. Teknologi mampu berpengaruh terhadap matematika yang diajarkan dan mampu meningkatkan proses belajar siswa. Teknologi dapat membantu siswa untuk memfokuskan diri pada ide-ide matematika, pemahaman, dan mampu menyelesaikan persoalan matematika yang tidak mungkin dikerjakan tanpa bantuan teknologi. Dengan pemanfaatan teknologi banyak soal-soal matematika dapat dipecahkan dan memungkinkan siswa tertentu lebih efektif untuk memahami bagian matematika yang penting. Pembelajaran dengan memanfaatkan teknologi dapat meningkatkan proses belajar matematika karena dengan memanfaatkan teknologi siswa dapat bereksplorasi yang lebih luas dan memperbaiki penyajian ide-ide matematika terutama tentang konsep-konsep geometri. Pemanfaatan teknologi dalam pembelajaran geometri sangat mendukung terwujudnya tujuan pembelajaran geometri di kelas.

Tujuan pembelajaran geometri untuk siswa dibedakan dalam dua bagian yaitu bagian pertama berkaitan dengan cara siswa berpikir dan memahami bentuk dan ruang, dan bagian kedua berupa materi dalam pemahaman dalam mengetahui tentang simetri, segitiga, garis-garis sejajar, dan sebagainya (Van De Walle, 2008:150). Dalam dokumen NCTM (2000:29) juga menyatakan bahwa lima standar isi yang dipelajari siswa dalam belajar yaitu bilangan dan operasinya, aljabar, geometri, pengukuran, serta analisis data dan peluang, selain itu ada lima standar proses yaitu: pemecahan masalah, penalaran dan pembuktian, komunikasi, koneksi, serta representasi. Tujuan pembelajaran geometri seiring dengan standar isi dan standar proses dari dokumen NCTM (2000:29).

Semua standar NCTM (2000:41) mendukung pemikiran bahwa keterampilan dan pemahaman akan geometri dapat dikembangkan oleh semua siswa. Seiring dengan para pakar teori dan peneliti, gagasan dalam membangun pemahaman siswa tentang geometri dari pemikiran informasi ke lebih formal. Pembelajaran geometri berguna untuk meningkatkan berpikir logis dan menggeneralisasi secara baik dan benar. Penguasaan geometri yang baik dapat meningkatkan pemahaman aritmatika, aljabar, kalkulus dan 
Vol 1 No 22020 Desember 2020

Jurnal AlphaEuclidEdu

lain-lain lebih baik. Konsep-konsep geometri berperan sebagai alat pembelajaran geometri di sekolah.

Menurut Cockroft (dalam Turmudi 2008:15) bahwa pembelajaran geometri di pendidikan menengah dimulai dengan cara sederhana dari konkret, semikonkret, semi abstrak dan abstrak, dari segi intuitif ke analisis, serta dari tahap yang paling sederhana hingga yang kompleks. Pembelajaran geometri dapat dikatakan dari konsep yang paling mudah menuju konsep yang sukar. Penyajian abstraksi pada geometri memberikan pengalaman visual dan spasial, misalnya pola, pengukuran, bidang dan pemetaan.

Menurut dokumen NCTM (2000: 41), kemampuan geometri siswa kelas 9- 12 harus memiliki kemampuan visualisasi, menganalisis dan penalaran spasial. Keabstrakan objek yang dimiliki oleh Geometri, menuntut siswa untuk mampu menganalisis gambaran hubungan karakter, sifat-sifat geometri dan mampu membangun argumen-argumen mengenai hubungan geometri dengan hal-hal nyata baik yang dapat divisualisasikan maupun yang tidak dapat divisualisasikan. Dengan menvisualisasi konsep geometri dapat mempermudah belajar geometri (Guzman, 2002:9). Visualisasi merupakan hal yang penting dalam belajar geometri atau yang berkaitan dengan keruangan, atau analitis matematis yang lain. Visualisasi dapat memberikan visual suatu permasalahan dalam memecahkan masalah. Visualisasi konsep geometri sangat membantu untuk memahami konsep geometri itu sendiri. Adapun Wileman (dalam Sweeney, 2017:63) mendeskripsikan berpikir visual sebagai kemampuan mengubah informasi dari semua jenis ke dalam gambar, grafik, atau bentuk-bentuk visual lain yang dapat mengomunikasikan informasi. Visualisasi konsep geometri merupakan kemampuan mengubah bentuk informasi ke visual atau bentuk lain. Kemampuan visualisasi merupakan salah satu level berpikir dari Teori Van Hiele.

Van Hiele (dalam Bautista, 2016:1281) mengembangkan teori tingkat/level berpikir geometri. Ada lima tingkat/level berpikir dalam memahami geometri yaitu level (0) Visualisasi, level (1) Analisis, level (2) Deduksi Informal, level (3) Deduksi dan level (4) Rigor. Adapun menurut Van De Walle (2008:155) bahwa karakteristik terkait dengan tingkatan pemikiran yaitu (1) level-level tersebut bertahap, (2) Tingkatantingkatan tidak bergantung usia, (3) pengalaman geometri merupakan faktor tunggal terbesar dalam mempengaruhi perkembangan dalam tingkatan-tingkatan tersebut, (4) Ketika instruksi atau bahasa yang digunakan terletak pada tingkatan yang lebih tinggi daripada tingkatan berpikir siswa yang dimiliki, akan ada komunikasi yang kurang. Dari kelima level Teori Van Hiele, taraf kebutuhan visual geometri tidak semuanya sama. Kebutuhan visual pada level lebih tinggi semakin berkurang, bahkan visual dapat dihilangkan untuk tingkat Rigor. Namun visual geometri tetap diperlukan dalam belajar geometri. Hal tersebut berkaitan erat dengan pembelajaran matematika khususnya geometri dengan memanfaatkan Software Geogebra.

Software Geogebra dapat membantu dalam memahami konsep-konsep geometri dan dapat menghasilkan visual geometri dengan teliti dan akurat dibandingkan dengan menggunakan pensil, penggaris, dan jangka. Software Geogebra mampu memberikan 
Vol 1 No 22020 Desember 2020

Jurnal AlphaEuclidEdu

fasilitas animasi dan gerakan-gerakan manipulasi (dragging). Sehubungan dengan hal tersebut software Geogebra dimanfaatkan dalam mengembangkan instrumen eksplorasi konsep geometri pada materi transformasi geometri. Menurut Van De Walle (2008:150) bahwa cakupan materi geometri Sekolah Menengah Atas meliputi bentuk dan sifat, transformasi, lokasi dan visualisasi.

Dari cakupan materi geometri tersebut, secara spesifik peneliti memilih materi transformasi geometri untuk mengembangkan instrumen eksplorasi pemahaman geometri yang berstruktur Teori Van Hiele dengan berbantuan software Geogebra di SMA Santu Petrus Pontianak. Dari pengamatan penulis dan wawancara guru, penguasaan materi transformasi geometri dari siswa SMA Santu Petrus masih belum dikuasai dengan baik sesuai dengan standar yang ditetapkan oleh pemerintah. Hasil temuan tersebut ternyata terkonfirmasi berdasarkan oleh Laporan Hasil Ujian Nasional Tahun 2016 Puspendik Kemendikbud menyatakan bahwa daya serap penguasaan kompetensi yang berkaitan dengan transformasi geometri tingkat kota Pontianak sebesar 29,14\%, tingkat Provinsi 27, 98\% dan tingkat nasional 36,80\%. Adapun daya serap penguasaan transformasi geometri oleh siswa di SMA Santu Petrus Pontianak pada Ujian Nasional Tahun 2016 sebesar 55,22\%. Daya serap ini tersebut tergolong relatif rendah. Rendahnya daya serap siswa dalam penguasaan materi transformasi geometri pada Ujian Nasional Tahun 2016 diduga penyebabnya antara lain belum tersedianya instrumen eksplorasi konsep transformasi geometri berbantuan software Geogebra dan strategi pembelajaran transformasi geometri yang digunakan tidak sesuai dengan tingkatan berpikir yang disarankan oleh teori berpikir Van Hiele.

Konsep-konsep transformasi geometri dapat divisualisasikan dengan berbantuan software geogebra. Konsep-konsep transformasi geometri dapat divisualisasi, dianalisis, dan dideduksi yang berstruktur Teori Van Hiele. Oleh sebab itu, transformasi geometri dapat sebagai materi pengembangan instrumen pada penelitian ini. Oleh karena itu peneliti ingin mengembangkan instrumen eksplorasi geometri berstruktur Teori Van Hiele berbantuan software Geogebra pada materi transformasi geometri.

\section{Metode Penelitian}

Metode dalam penelitian ini adalah metode penelitian dan pengembangan (Research and Development) yang ditujukan untuk menghasilkan perangkat instrumen eksplorasi konsep geometri berstruktur Teori Van Hiele berbantuan software Geogebra yang valid dan praktis. Penelitian ini dilakukan dalam empat tahap yaitu tahap memunculkan ide/gagasan dan studi pendahuluan, pengembangan produk, uji coba, dan validasi produk.

\section{Tahap Memunculkan Ide/Gagasan dan Studi Pendahuluan}

Pada tahap ini terdiri atas dua kegiatan yaitu kegiatan memunculkan ide/gagasan awal dan melaksanakan studi pendahuluan. Studi pendahuluan terdiri atas survei lapangan dan survei kepustakaan. Dari tahap pertama ini melahirkan produk awal sebagai embrio produk pendidikan yang hendak dikembangkan. 
Vol 1 No 22020 Desember 2020

Jurnal AlphaEuclidEdu

\section{Tahap Pengembangan Produk}

Pada tahap pengembangan produk ini yakni mengimplementasikan produk awal dan menilainya dari sudut pandang proses pada lokasi dan subjek penelitian yang sangat terbatas.

\section{Tahap Uji Coba}

Pada tahap ini dilakukan uji coba produk yang terdiri atas uji coba terbatas dan uji coba yang lebih luas. Yang dinilai dari uji coba ini adalah proses dan hasil belajar. Pada tahap ini diharapkan menghasilkan produk hipotetik.

\section{Tahap Validasi Produk}

Pada tahap validasi produk sebagai kegiatan pasca pengembangan yang terdiri atas kegiatan pengujian validasi produk untuk menilai keandalan produk hasil pengembangan dan kegiatan diseminasi serta pelaporan.

\section{Hasil Penelitian dan Pembahasan}

\subsection{Hasil Penelitian dan Analisis Data}

Hasil studi pendahuluan dan analisis kebutuhan perangkat instrumen yang digunakan untuk eksplorasi konsep Geometri berstruktur Teori Van Hiele di SMA Santu Petrus Pontianak terdiri atas studi pendahuluan dan pengembangan instrumen. Studi pendahuluan yang dilaksanakan meliputi survei lapangan dan studi pustaka. Survei lapangan penelitian ini meliputi identitas sekolah, tenaga pendidik sebanyak 54 guru terdiri dari 29 guru tetap yayasan dan 25 guru tidak tetap, 6 dari 7 guru matematika dalam pengembangan instrumen belum menggunakan software Geogebra, survei kondisi subjek penelitian, iklim sosial dan iklim psikologis, keadaan sarana dan prasarana terdapat 3 ruang laboratorium komputer dengan setiap ruang berisi 45 unit komputer dan setiap minggu terdapat 4 jam pelajaran komputer, cara belajar siswa terdapat sebagian besar siswa cara belajarnya di sekolah cenderung masih menggunakan hafalan dan kurang mengembangkan daya eksplorasi dan nalarnya dalam memecahkan masalah geometri. Kriteria ketuntasan minimal (KKM) dari penilaian hasil belajar siswa di SMA Santu Petrus pada mata pelajaran Matematika ditetapkan sebesar 70.

Pada pengembangan instrumen ini dilaksanakan analisis pendahuluan yang terdiri atas analisis karakteristik siswa, analisis kurikulum, analisis materi, analisis instruksional dan analisis kebutuhan terhadap instrumen. Karakteristik umur siswa SMA Santu Petrus pada rentang 16 tahun sampai dengan 19 tahun. Analisis kurikulum di SMA Santu Petrus menggunakan Kurikulum 2013 dan diperoleh bahwa kelas XI jurusan Matematika dan Ilmu Alam terdapat kompetensi dasar yang memuat konsep geometri yaitu Kompetensi Dasar yang menganalisis sifat-sifat transformasi geometri meliputi pergeseran, pencerminan, perputaran dan dilatasi dengan pendekatan koordinat. Pada analisis materi untuk mengidentifikasi materi geometri yang tercatum dalam kurikulum. Analisis kebutuhan instrumen didasarkan dari hasil wawancara dengan guru matematika yang mengajar dan pengamatan pada buku catatan siswa di SMA Santu Petrus. Berdasarkan pengamatan, instrumen yang dipergunakan guru untuk 
Vol 1 No 22020 Desember 2020

Jurnal AlphaEuclidEdu

mengeksplorasi konsep geometri belum berstruktur teori Van Hiele dan berbantuan Software Geogebra.

Dari studi pendahuluan dan analisis pendahuluan disusun instrumen awal sebagai produk awal (prototype 1) yang terdiri dari kisi-kisi soal, butir soal sebanyak 16 butir soal, apllet geogebra yang dirancang berstruktur teori tingkat berpikir Van Hiele, pedoman penskoran butir soal, dan alternatif jawaban yang akan dikembangkan lebih lanjut. Prototype 1 dikembangkan, diujicobakan dan dianalisis serta dilakukan perbaikan sehingga menjadi prototype 2 . Prototype 2 dilakukan ujicoba dan analisis serta perbaikan sehingga menjadi prototype 3 . Demikian juga prototype 3 dilakukan pengujian dan analisis produk serta perbaikan sehingga didapatkan produk yang diharapkan dengan kualitas baik.

Prototype 1 ini merupakan instrumen eksplorasi konsep geometri berstruktur dari Teori Van Hiele berbantuan Software Geogebra yang terdiri dari kisi-kisi soal, butir soal, pedoman penskoran dan alternatif jawaban yang difokuskan dari segi konten(isi), konstruksi dan bahasa. Kisi-kisi dari prototype 1 dibuat berdasarkan kompetensi dasar, indikator soal, dan Teori Tingkat Berpikir Van Hiele pada materi transformasi geometri kelas XI di SMA. Penyebaran instrumen disajikan pada Tabel 1 berikut:

Tabel 1 Penyebaran Instrumen

\begin{tabular}{llll}
\hline $\begin{array}{l}\text { Tingkat Berpikir Teori } \\
\text { Van Hiele }\end{array}$ & Tranformasi Geometri & Banyak Soal & Nomor Soal \\
\hline Level 0 Visualisasi & $\begin{array}{l}\text { Visualisasi obyek translasi, } \\
\text { refleksi garis, dilatasi dan rotasi }\end{array}$ & 5 soal & $1,2,3,4,5$ \\
\hline Level 1 Analisis & $\begin{array}{l}\text { Sifat-sifat translasi, refleksi garis, } \\
\text { dilatasi dan rotasi }\end{array}$ & 5 soal & $6,7,8,9,10$ \\
\hline $\begin{array}{l}\text { Level } 2 \\
\text { Informal }\end{array}$ & $\begin{array}{l}\text { Komposisi transformasi Translasi, } \\
\text { Refleksi garis, Rotasi, dan } \\
\text { Dilatasi }\end{array}$ & 3 soal & $11,12,13$ \\
\hline Level 3 Deduksi & $\begin{array}{l}\text { Kombinasi transformasi Translasi, } \\
\text { refleksi garis, Rotasi, dan Dilatasi }\end{array}$ & 3 Soal & $14,15,16$ \\
\hline
\end{tabular}

Pada Tabel 1 menunjukkan bahwa penyebaran instrumen pada level berpikir Teori VanHiele terdiri atas 5 level 0 visualisasi, 5 soal level 1 analisis, 3 soal level 2 deduksi informal dan 3 soal level 3 deduksi. Prototype I merupakan ujian tertulis dengan bentuk soal essay yaitu isian singkat dan uraian terbuka. Pada tahap One-to-one dilakukan ujicoba Prototype I sebanyak dua kali untuk menemukan kelemahan dan kemudian dilakukan revisi. Hasil revisi dari prototype 1 dinamakan prototype 2. Prototype 2 yang dihasilkan selanjutnya dilakukan uji coba pada tahap Small grup yang melibatkan 15 siswa kelas XI Jurusan Matematika dan Ilmu-ilmu Alam di SMA Santu Petrus Pontianak. Hasil penskoran uji coba Small grup kemudian dilakukan analisis kuantitatif yang meliputi analisis validitas empiris, reliabilitas, daya pembeda dan tingkat kesukaran. Dari analisis tersebut diperoleh kelemahan dari instrumen yang dipakai untuk dijadikan dasar merevisi prototype 2. Hasil perhitungan diperoleh satu soal 
Vol 1 No 22020 Desember 2020

Jurnal AlphaEuclidEdu

dengan validitas kategori sangat tinggi, 8 soal dengan validitas tinggi, 3 soal dengan validitas cukup/sedang dan 3 soal dengan validitas rendah, reliabilitas soal sangat tinggi, tingkat kesukaran 4 soal kategori mudah, 9 soal kategori sedang dan 3 soal kategori sukar, daya pembeda ada 2 soal dengan daya pembeda rendah, 8 soal daya pembeda sedang dan 6 soal daya pembeda tinggi. Kelemahan prototype 2 diperbaikan dan direvisi sehingga diperoleh prototype 3 . Karakteristik dari prototype 3 adalah perangkat soal yang telah tervalidasi dari segi konten(isi), konstruksi dan bahasa oleh para ahli, dapat terbaca dengan baik melalui uji keterbacaan dan telah diujicobakan dalam skala kecil sehingga diperoleh hasil perhitungan validitas, reliabilitas, tingkat kesukaran dan daya pembedanya. Prototype 3 ini selanjutnya diujicobakan pada subjek dengan kelompok yang lebih luas (field grup) yang melibatkan 36 siswa dari kelas XI Jurusan Matematika Ilmu Alam SMA Santu Petrus Pontianak. Kelemahan-kelemahan pada uji coba tahap field tes ini dipergunakan untuk menyempurnakan prototype 3 menjadi produk akhir dari penelitian ini. Hasil uji coba soal untuk ketepatan instrumen tahap field tes yang dapat dilihat dari validitas butir soal, reliabilitas, daya pembeda dan tingkat kesukaran. Hasil uji coba butir soal tahap field tes disajikan pada Tabel 2 sebagai berikut:

Tabel 2. Rekapitulasi Hasil Analisis Uji Coba pada Field Tes

\begin{tabular}{|c|c|c|c|c|}
\hline Soal & $\begin{array}{l}\text { Validitas } \\
\text { Empiris }\end{array}$ & Reliabilitas & $\begin{array}{l}\text { Daya } \\
\text { Pembeda }\end{array}$ & $\begin{array}{l}\text { Indeks } \\
\text { Kesukaran }\end{array}$ \\
\hline 1 & 0,45 & \multirow{16}{*}{0,998} & 0,11 & 0,50 \\
\hline 2 & 0,60 & & 0,13 & 0,47 \\
\hline 3 & 0,44 & & 0,15 & 0,39 \\
\hline 4 & 0,45 & & 0,15 & 0,35 \\
\hline 5 & 0,57 & & 0,20 & 0,40 \\
\hline 6 & 0,71 & & 0,21 & 0,49 \\
\hline 7 & 0,83 & & 0,43 & 0,38 \\
\hline 8 & 0,66 & & 0,21 & 0,38 \\
\hline 9 & 0,71 & & 0,21 & 0,51 \\
\hline 10 & 0,83 & & 0,26 & 0,38 \\
\hline 11 & 0,73 & & 0,25 & 0,30 \\
\hline 12 & 0,82 & & 0,33 & 0,24 \\
\hline 13 & 0,84 & & 0,35 & 0,23 \\
\hline 14 & 0,79 & & 0,33 & 0,22 \\
\hline 15 & 0,71 & & 0,25 & 0,17 \\
\hline 16 & 0,67 & & 0,22 & 0,15 \\
\hline
\end{tabular}

Berdasarkan Tabel 2 menunjukkan bahwa (i) hasil uji validitas Empiris butir soal terdapat 11 soal memiliki validitas dengan kriteria baik dan ada 5 soal dengan validitas cukup; (ii) hasil uji reliabilitas butir soal diperoleh nilai $\mathrm{r} 11=0,998$ yang tergolong kriteria sangat baik;(iii) daya pembeda terdapat 3 soal kriteria sangat baik, 2 butir soal kriteria cukup baik, ada 6 soal daya pembeda dengan kriteria rendah dan daya pembeda 
Vol 1 No 22020 Desember 2020

Jurnal AlphaEuclidEdu

kriteria jelek ada 5 soal. Berdasarkan hasil perhitungan daya pembeda tersebut, perlu dilakukan diadakan revisi soal sebanyak 4 butir soal. Revisi dilakukan pada Applet Geogebra; (iv) tingkat kesukaran butir soal ada 5 soal kriteria sukar dan 11 soal kriteria sedang.

Hasil uji kepraktisan terhadap soal lebih menekankan pada kemudahan dalam pembuatan instrumen, penggunaan instrumen, pemeriksaan dan penilaian serta efisien dari segi biaya dan tenaga. Pembuatan instrumen ini menggunakan Software Geogebra versi 5.0. Software Geogebra ini dapat diunduh secara gratis di internet. Software Geogebra dapat dioperasikan melalui komputer dan gadget.

Berdasarkan hasil perhitungan analisis butir soal pada field tes yaitu perhitungan analisis uji validitas, reliabilitas, daya pembeda dan tingkat kesukaran menunjukkan bahwa semua soal dapat dikatakan valid dengan reliabilitas sangat tinggi serta tingkat kesukaran sedang atau sukar. Adapun dari daya pembeda terdapat daya pembeda dengan kriteria sangat baik, cukup baik, rendah dan masih terdapat soal-soal yang memiliki daya pembeda dengan kriteria jelek. Penggunaan instrumen ini menekankan pada sarana dan prasarana penunjang, respon siswa dan penilaian guru. Instrumen ini menggunakan sarana komputer atau gadget dan Software Geogebra.

Analisis Tingkat Berpikir Siswa SMA tentang Konsep Geometri Berstruktur Teori Van Hiele. Instrumen penelitian ini diujicobakan pada 36 siswa kelas XI jurusan Matematika dan Ilmu-ilmu Alam di SMA Santu Petrus Pontianak. Menurut kriteria Usiskin (1982) tentang kriteria kelulusan di setiap tingkat berpikir geometri Teori Van Hiele adalah 60. Dari hasil ujicoba 36 siswa diperoleh banyaknya siswa pada perkembangan tingkat berpikir level (3) Deduksi ada 2 siswa; tingkat (2) Deduksi Informal sebanyak 11 orang; tingkat (1) Analisis sebanyak 24 siswa dan tingkat (0) sebanyak 34 siswa. Sedangkan masih ada 4 siswa yang belum pada level (0) Visualisasi dari Teori Van Hiele. Data tersebut disajikan dalam bentuk diagram garis pada Grafik 1:

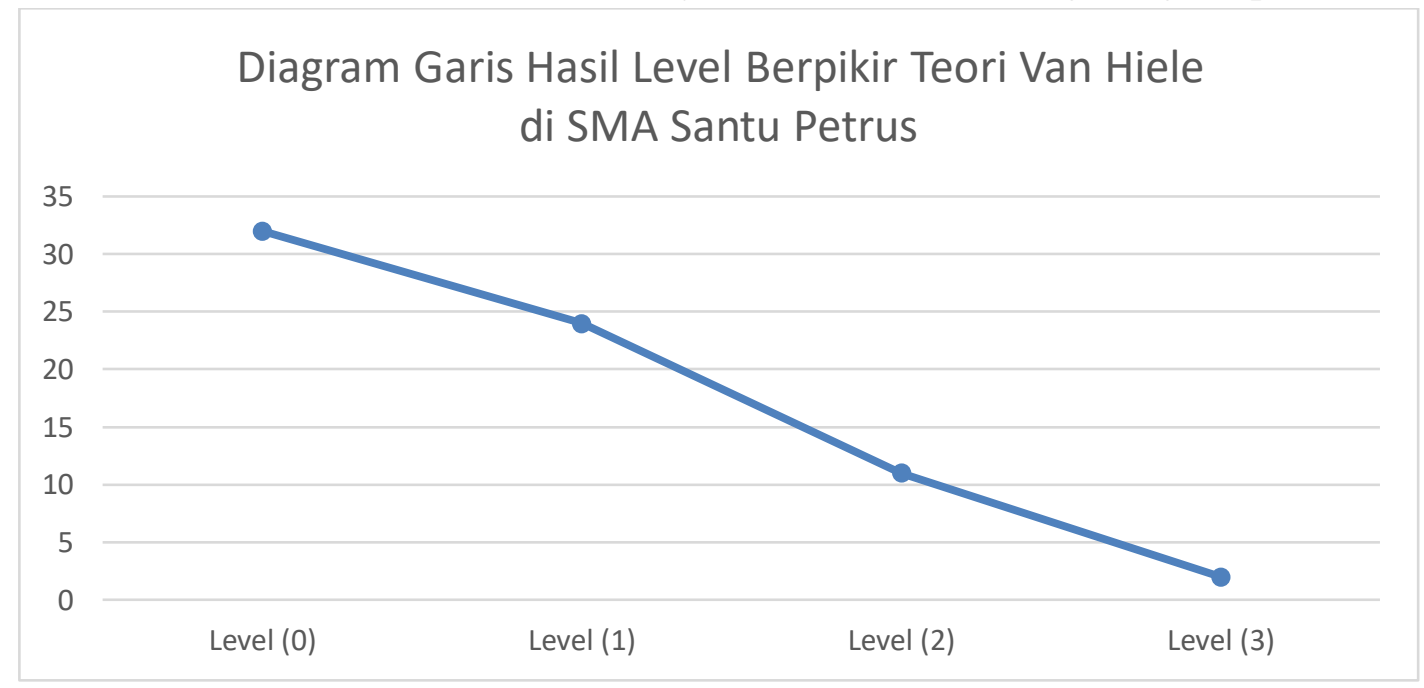

Grafik 1. Hasil Level Berpikir Teori Van Hiele siswa kelas XI MIA di SMA Santu Petrus

Tahun Pelajaran 2016/2017 
Vol 1 No 22020 Desember 2020

Jurnal AlphaEuclidEdu

Berdasarkan Grafik 1 menunjukkan bahwa grafiknya menurun dengan banyaknya siswa pada tingkat berpikir level 3 lebih sedikit dari level 2 atau level 1 atau level 0.

\subsection{Pembahasan Hasil Penelitian}

Pengembangan instrumen ini untuk mengetahui apakah instrumen yang ada di SMA Santu Petrus telah memenuhi kebutuhan untuk mengeksplorasi konsep geometri berstruktur Teori Van Hiele. Pengembangan instrumen ini didahului dengan studi pendahuluan, analisis pendahuluan dan pengembangan instrumen. Hal ini sejalan dengan pendapat Wina (2013:137-138), studi pendahuluan yang dilakukan berguna untuk memahami lebih dalam tentang ide/gagasan menciptakan produk yang sesuai dengan kebutuhan. Kegiatan ini perlu dilakukan untuk menjamin bahwa produk yang dihasilkan adalah produk yang berangkat dari kebutuhan, sehingga pada gilirannya produk yang dihasilkan bermanfaat di lapangan. Studi pendahuluan yang dilaksanakan pada penelitian ini meliputi survei lapangan dan studi pustaka. Survei lapangan ini untuk mendapatkan informasi tentang potensi sekolah yang terkait dengan pengembangan instrumen. Adapun survei lapangan dalam penelitian ini meliputi identitas sekolah, tenaga pendidik, perangkat instrumen matematika, survei kondisi subjek penelitian, cara belajar siswa, iklim sosial dan iklim psikologis, keadaan sarana dan prasarana, dan sistem evaluasi yang digunakan di lapangan. SMA Santu Petrus beralamatkan di Jalan Karel Satsuit Tubun Nomor 3 Pontianak yang merupakan salah satu sekolah berakreditasi A sebagai pelaksana terbatas Kurikulum 2013 sejak tahun 2012 dan pelaksana Ujian Nasional Berbasis Komputer (UNBK) sejak tahun 2016.

Tenaga pendidik di SMA Santu Petrus sebanyak 56 orang terdiri dari 29 guru tetap yayasan, 25 guru tidak tetap yayasan. Guru yang mengasuh mata pelajaran matematika sebanyak 7 orang yang terdiri dari 5 guru dengan masa kerja lebih 5 tahun dan 2 guru matematika kurang dari 5 tahun. Siswa di SMA Santu Petrus pada tahun pelajaran 2016/2017 sebanyak 1225 siswa yang terbagi dalam 31 rombongan belajar. Perbandingan banyaknya guru matematika dan siswa adalah 1: 175. siswa kelas $X$ sebanyak 392 siswa dan terbagi 10 rombongan belajar, kelas XI sebanyak 483 siswa dengan 12 rombongan belajar dan kelas XII sebanyak 350 siswa dengan 9 rombongan belajar. Banyaknya siswa laki-laki dengan perempuan cukup berimbang yaitu 618 siswa laki-laki dan 607 siswa perempuan. Sebagian besar siswa berdomisili di kota Pontianak dengan persentase sebesar $82 \%$ dan $18 \%$ di luar kota Pontianak. SMA Santu Petrus menggunakan Kurikulum 2013 dengan dua jurusan yaitu jurusan Matematika dan Ilmuilmu Alam (MIA) dan Ilmu-ilmu Sosial (IS). Pada Kurikulum 2013 mata pelajaran Teknologi Informasi dan Komputer ditiadakan namun SMA Santu Petrus tetap memberikan Mata Pelajaran Teknologi Informasi dan Komputer (TIK) sebanyak 4 jampel seminggu yaitu 2 jampel untuk mata pelajaran Prakarya dan 2 jampel sebagai Ekstrakurikuler wajib. Banyak laboratorium komputer ada 3 ruangan dengan masingmasing ruang berisi 45 unit komputer. Sistem manajemen dan informasi sekolah berbasis google Classroom, google kalender, grup line dan berbasis website dengan alamat sekolah www.smapetrus.net. Pengumuman dari sekolah, materi pembelajaran 
Vol 1 No 22020 Desember 2020

Jurnal AlphaEuclidEdu

dan tugas-tugas dari dapat diakses melalui google Classroom, grup line dan berbasis website. Adapun penerima siswa baru di SMA Santu Petrus tanpa menggunakan seleksi yang ketat sehingga kemampuan siswa baru di SMA Santu Petrus sangat beranekaragam. Oleh sebab itu pembagian rombongan belajar siswa berdasarkan minat siswa serta sistem pemerataan kemampuan dan gender di masing-masing rombongan belajar. Hal ini membentuk iklim sosial dan iklim psikologis dengan ciri khas tersendiri. Peran wali kelas di SMA Santu Petrus dioptimalkan untuk pembinaan dan pendampingan siswa di masing-masing kelas agar tercipta kondisi belajar yang kondusif di kelas dan di luar kelas. Kriteria keberhasilan pembelajaran di SMA Santu Petrus diukur dari ketercapaian didasarkan pada ketercapaian standar kelulusan, kompetensi inti, dan kompetensi dasar pada masing-masing mata pelajaran dengan kriteria ketuntasan minimal (KKM) terendah sebesar 70.

Studi kepustakaan pada penelitian ini dilakukan untuk meningkatkan pemahaman secara teoritis tentang pengembangan instrumen. Studi kepustakaan dilakukan dengan membaca, mencari literatur dan memahami artikel, jurnal, buku-buku, dan penelitian terdahulu yang berkaitan dengan pengembangan instrumen ini.

Analisis pendahuluan meliputi analisis karakteristik siswa, analisis kurikulum, analisis materi, analisis instruksional dan analisis kebutuhan terhadap instrumen. Karakteristik siswa SMA Santu Petrus ditinjau dari perkembangan fisik, intelektual dan perilaku sosial sebagai berikut.

Berdasarkan data umur siswa SMA Santu Petrus Pontianak Tahun pelajaran 2016/2017 bahwa persentase banyaknya siswa berumur 16 tahun berjenis kelamin lakilaki sebanyak 15,84\% dan perempuan 14,94\%; siswa berumur 17 tahun berjenis kelamin laki-laki $19,59 \%$ dan perempuan 20,65\%; siswa berumur 18 tahun berjenis kelamin laki-laki 12,65\% dan perempuan 11,84\% sisnya berumur 15 tahun, 19 tahun dan 20 tahun sebesar 4,49\%. Berdasarkan data tersebut bahwa persentase tertinggi adalah siswa berjenis perempuan berumur 17 tahun yaitu 20,65\% dan laki-laki berumur 17 tahun sebesar 19,59\%. Karakteristik umur siswa berdasarkan jenis kelamin dan setiap tingkatan kelasnya di SMA Santu Petrus memiliki karakteristik tersendiri. Menurut data domisili siswa bahwa $82 \%$ siswa berdomisi di kota pontianak dan $18 \%$ siswa berdomisili di luar Kota Pontianak. Hal ini sebagian besar siswanya memiliki berkehidupan sehari-hari pada lingkungan di kota.

Tingkat Kelas dalam penelitian ini adalah tingkat kelas XI jurusan Matematika dan Ilmu Alam (MIA) dan Kompetensi Dasar aspek pengetahuan adalah KD 3.20. menganalisis sifat-sifat transformasi geometri (pergeseran, pencerminan, perputaran dan dilatasi) dengan pendekatan koordinat dan menerapkannya dalam menyelesaikan masalah dan kompetensi dasar aspek keterampilan adalah KD 4.15. menyajikan objek kontekstual, menganalisis informasi terkait sifat-sifat objek dan menerapkan aturan transformasi geometri dalam memecahkan masalah.

Analisis kebutuhan terhadap instrumen ini diperlukan menggali informasi kebutuhan guru terhadap instrumen eksplorasi konsep geometri berbantuan Software 
Vol 1 No 22020 Desember 2020

Jurnal AlphaEuclidEdu

Geogebra. Dari wawancara dengan guru matematika yang mengajar di SMA Santu Petrus diperoleh informasi bahwa dalam pembelajaran guru sudah pernah memberikan dan menggunakan soal-soal untuk mengeksplorasi konsep geometri namun soal-soal yang dipakai belum berstruktur teori van Hiele dan belum berbantuan Software Geogebra. Menurut guru bahwa soal-soal jenis eksplorasi memerlukan ketersediaan waktu yang cukup untuk melakukan penyelidikan. Hal ini sejalan dengan pendapat Turmudi (2008:3).

Dari hasil respon siswa dan wawancara dengan siswa bahwa pemakaian sofware Geogebra dapat membantu mempermudah menyelesaiakan soal-soal yang diberikan. Oleh karena itu, instrumen yang dikembangkan dapat mengeksplorasi konsep geometri yang berstruktur dari Teori Tingkat Berpikir Van Hiele dan berbantuan Software Geogebra dan dapat sebagai alat pengukuran pencapaian hasil belajar siswa dan memberikan gambaran/profil tingkat berpikir bidang goemetri yang dimiliki siswa berdasarkan Teori Van Hiele.

Karakteristik Instrumen Eksplorasi Konsep Geometri Berstruktur dari Teori Van Hiele berbantuan Software Geogebra di SMA sebagai berikut: pengembangan instrumen didahului dengan studi pendahuluan dan analisis pendahuluan dan disusun instrumen awal (prototype 1) sebagai produk awal. Prototype 1 terdiri dari kisi-kisi soal, butir soal dan applet geogebra, pedoman penskoran, dan alternatif jawaban. Prototype 1 ini ditelaah oleh rekan sejawat dari segi konten (isi), konstruksi, dan bahasa dan kemudian diujicobakan pada 6 siswa sebagai subjek penelitian. Prototype I merupakan seperangkat instrumen dirancang berstruktur dari teori tingkat berpikir Van Hiele berbantuan Software Geogebra. Banyaknya butir soal yang disusun ada 16 butir soal. Setiap butir soal terdiri dari dua bagian yaitu bagian pokok soal dan applet Geogebra. Instrumen ini terdiri 5 soal level 0 Visualisasi, 5 soal level 1 Analisis, 3 soal level 2 deduksi informal dan 3 soal level 3 deduksi menurut teori tingkat berpikir Van Hiele.

Ujicoba prototype I pada tahap One-to-one dilakukan sebanyak dua kali. Uji coba One-to-one tahap pertama diujikan pada tiga siswa. Hasil uji coba One-to-one tahap I menekankan uji keterbacaan dan proses pengerjaan instrumen. Temuan kelemahankelemahan dari ujicoba One-to-one tahap I dipergunakan untuk merevisi prototype I. Uji coba kedua pada tahap One-to-one ini melibatkan 3 siswa. Hasil temuan dari kelemahan yang ditinjau bukan hanya aspek konten, kontruksi dan bahasa namun juga dari aspek proses mengerjakan instrumen pada prototype I dan respon siswa. Prototype I yang telah diujicobakan dan dilakukan revisi pada tahap One-to-one kemudian divalidasi oleh pakar ahli. Pakar ahli pada kegiatan experts review dilakukan oleh dua guru matematika alumni S2 Pendidikan Matematika Universitas Tanjungpura dan seorang dosen S2 Pendidikan Matematika Universitas Tanjungpura. Hasil validasi experts review dari aspek konten diperoleh 91,47\% dengan kategori valid, aspek kontruksi sebesar 90,18\% dengan kategori sangat valid dan aspek bahasa sebesar 91,82\% dengan kategori sangat valid. Rata-rata validitas ketiga validator experts review pada prototype 1 sebesar 91,16\% dengan kategori sangat valid. Prototype 1 yang telah 
Vol 1 No 22020 Desember 2020

Jurnal AlphaEuclidEdu

divalidasi oleh pakar ahli dan dilakukan analisis serta dilakukan perbaikan sehingga diperoleh prototype 2. Prototype 2 selanjutnya dilakukan uji coba pada tahap Small grup yang melibatkan 15 siswa kelas XI Jurusan Matematika dan Ilmu-ilmu Alam di SMA Santu Petrus Pontianak. Seusai siswa mengerjakan soal, siswa tersebut mengisi angket dan menuliskan saran atau komentar. Jawaban siswa yang terkumpul dilakukan koreksi berdasarkan kunci jawaban dan pedoman penskoran. Hasil penskoran dilakukan analisis kuantitatif yang meliputi analisis validitas empiris, reliabilitas, daya pembeda dan tingkat kesukaran. Hasil perhitungan dari analisis kuantitatif diperoleh sebagai berikut; 1)ada satu butir soal memiliki validitas sangat tinggi, ada 8 butir soal dengan validitas tinggi dan validitas cukup ada 3 butir soal serta ada 3 butir soal dengan validitas rendah; 2) Soal memiliki reliabilitas sangat tinggi; 3) Tingkat kesukaran mudah ada 4 soal, sedang ada 7 soal dan sukar ada 3 soal; 4) daya pembeda minimum/rendah ada 2 soal, sedang ada 8 soal dan tinggi ada 6 soal.

Prototype 2 yang telah direvisi menjadi prototype 3 selanjutnya diujicobakan pada subjek dengan kelompok yang lebih luas (field grup) yang melibatkan 36 siswa. Hasil uji coba pada tahap ini dianalisa secara kuantitatif dan kualitatif. Analisis kuantitatif meliputi analisis validits empiris, reliabilitas, daya pembeda dan tingkat kesukaran soal. Analisis kualitatif dilakukan dengan mengamati subjek saat mengerjakan soal, melakukan wawancara dengan subjek, dan meminta respon siswa setelah mengerjakan soal. Kelemahan-kelemahan yang diperoleh dipergunakan untuk menyempurnakan prototype 3 menjadi produk akhir dari penelitian ini.

Penyempurnaan prototype 3 menjadi produk akhir meliputi perbaikan pada applet Geogebra dengan menambah obyek/gambar dan dilengkapi petunjuk pada applet Geogebra untuk beberapa soal tertentu saja. Produk akhir ini merupakan instrumen eksplorasi konsep geometri berstruktur dari Teori Van Hiele berbantuan Software Geogebra di SMA berisi kisi-kisi soal, seperangkat soal terdiri dari pokok soal dan file applet Geogebra sebanyak 16 soal, kunci jawaban dan pedoman penskoran. Karakteristik instrumen produk akhir sebagai berikut: (1) Validitas Empiris, terdapat 11 soal memiliki validitas dengan kriteria baik dan ada 5 soal dengan validitas cukup; (2) Reliabilitas butir soal sebesar nilai r11 $=0,998$ dengan kriteria sangat baik; (3) Daya Pembeda, ada 3 soal dengan daya pembeda sangat baik, daya pembeda dengan kriteria cukup baik ada 2 butir soal dan daya pembeda dengan kriteria rendah ada 6 soal dan daya pembeda kriteria jelek ada 5 soal; (4) Tingkat Kesukaran ada 5 soal kriteria sukar, ada 11 soal kriteria sedang.

Tingkat Berpikir Siswa SMA tentang konsep geometri berstruktur Teori Van Hiele sebagai berikut: Instrumen diujicobakan kepada 36 siswa kelas XI jurusan Matematika dan Ilmu-ilmu Alam di SMA Santu Petrus Pontianak diperoleh banyaknya siswa pada perkembangan tingkat berpikir level (3) Deduksi sebanyak 2 siswa; tingkat (2) Deduksi Informal sebanyak 11 orang; tingkat (1) Analisis sebanyak 24 siswa dan tingkat (0) visualisasi sebanyak 32 siswa. Sedangkan masih ada 4 siswa yang belum pada level (0) Visualisasi dari Teori Van Hiele. Hal ini dapat dikatakan bahwa semakin tinggi 
Vol 1 No 22020 Desember 2020

Jurnal AlphaEuclidEdu

tingkatan berpikir menurut Teori Van Hiele, banyaknya siswa semakin berkurang. Perubahan tersebut berbanding terbalik antara banyaknya siswa dan tingginya level/tingkatan berpikir geometri dari Teori Van Hiele.

\section{Kesimpulan}

Berdasarkan dari hasil penelitian dan analisis data yang diperoleh serta pembahasan, penulis menyimpulkan sebagai berikut:

1. Perangkat instrumen yang digunakan telah memenuhi kebutuhan untuk mengeksplorasi konsep geometri berstruktur Teori Van Hiele di Sekolah Menengah Atas.

2. Karakteristik perangkat instrumen yang dikembangkan pada penelitian ini adalah perangkat instrumen eksplorasi konsep geometri berstruktur dari Teori Van Hiele dengan berbantuan Software Geogebra yang terdiri dari kisi-kisi soal, pokok soal dan file applet Geogebra, pedoman penskoran, dan alternatif jawaban.

3. Perangkat instrumen yang dikembangkan telah divalidasi oleh pakar ahli, dianalisis ketepatan meliputi analisis validitas empiris, reliabilitas, daya pembeda, dan tingkat kesukaran. Hasil perhitungan validitas empiris diperoleh 11 soal dengan kriteria baik dan 5 soal dengan kriteria cukup; reliabilitas butir soal sebesar dengan kriteria sangat baik; daya pembeda diperoleh 3 soal dengan kriteria baik, 2 soal dengan kriteria cukup baik dan 6 soal dengan kriteria rendah serta 5 soal dengan kriteria jelek: tingkat kesukaran diperoleh 4 soal kriteria sukar, dan 8 soal kriteria sedang dan 4 soal kriteria mudah. Berdasarkan rekapitulasi hasil respon siswa diperoleh rata-rata persentase kesetujuan siswa sebesar $84 \%$. dan hasil respon siswa terhadap kontruksi soal sebesar $80 \%$ dan hasil respon siswa terhadap bahasa sebesar $81 \%$.

4. Hasil pengujian instrumen eksplorasi konsep Geometri berstruktur dari teori Van Hiele berbantuan software Geogebra kepada 36 subjek di SMA Santu Petrus tahun pelajaran 2016/2017 diperoleh informasi perkembangan tingkat berpikir visualisasi sebanyak 32 siswa, tingkat berpikir analisis sebanyak 24 siswa, tingkat berpikir deduksi informal sebanyak 11 orang dan tingkat berpikir deduksi ada 2 siswa serta masih ada 4 siswa yang belum mencapai pada tingkat berpikir Visualisasi. Hal ini dapat dikatakan bahwa banyaknya siswa yang berpikir dengan tingkatan semakin tinggi menurut Teori Van Hiele semakin berkurang.

\section{Referensi}

Bautista, Gerome H. 2016. An Assessment of Grade 8 Geometry Teaching Guide of the $\mathrm{K}$ to 12 Basic Education Program Based on Van Hiele Model of Geometric Thinking and Department of Education's Standards. Saint Mary's University, Nueva Vizcaya, Philippines. [online], tersedia: http://pubs.sciepub.com/education/4/18/6/index.html.

Crowley, Mary L..1987. The Van Hiele Model of The Development of Geometric Thought. Yearbook of NCTM. 
Vol 1 No 22020 Desember 2020

Jurnal AlphaEuclidEdu

Depdiknas.2008. Panduan Penulisan Butir Soal. Jakarta:Direktorat PSMA.

Guzman, Miguel de. 2002. The Role of Visualisation in Teaching and Learning of Mathematical Analysis. Universidad Complutense de Madrid. [online], tersedia: http://files.eric.ed.gov/fulltext/ED472047.pdf.

Hohenwarter, Markus. 2008. Teaching and Learning Calculus With Free Dinamic Mathematics Software GeoGebra. [online], tersedia: https://archive.geogebra.org/static/publications/2008-ICME-TSG16-CalculusGeoGebra-Paper.pdf.

Kennedy, Leonard M. Tipps, Steve, \& Johnson, Art. 2008. Guiding Childern's Learning of Mathematics. Belmont, USA: Thomson Wadsworth.

Mahmudi, A.2010. Membelajarkan Geometri dengan Program GeoGebra. Makalah dipresentasikan dalam Seminar Nasional Matematika dan Pendidikan Matematika Jurusan Pendidikan Matematika FMIPA UNY. [Online]. Tersedia: http://eprints.uny.ac.id/10483/1/P6-Ali\%20M.pdf.

NCTM. 2000. Principles and Standards for School Mathematics. Virginia: NCTM, Inc.

Putra, Nusa. 2015. Research Development-Penelitian dan Pengembangan: Suatu Pengantar. Jakarta: PT RajaGrafindo Perkasa.

Sugiono. 2016. Metode Penelitian dan Pengembangan (Research and Development/R\&D). Bandung: Penerbit Alfabeta.

Sumaryanta. 2015. Pedoman Penskoran. PPPPTK Matematika, Yogyakarta.

Sweeney, Susan. 2017. Integrating Visual Literacy Training into the Business Curriculum. A Case Study at Dublin Business School. School of Business and Law Dublin Business School Dublin, Ireland. [online], tersedia: https://dbsbusinessreview.ie/index.php/journal/article/view/7/6.

Tessmer, Martin.1993. Planning and Conducting Formative Evaluations. British Library.

Turmudi. 2008. Landasan Filsafat dan Teori Pembelajaran Matematika (Berparadigma Eksploratif dan Integratif). Jakarta : Leuser Cipta Pustaka.

Usiskin, Zalman. 1982. Van Hiele Levels and Achievement in Secondary School Geometry. CDASSG Project. National Inst. Of Education (ED), Washington, DC.

Van De Walle, John. A. 2008. Matematika Sekolah Dasar dan Menengah Jilid 2 Pengembangan Pengajaran. Jakarta: PT Erlangga.

Watson, Conoiah. 2012. A Comparison of Van Hiele Levels and Final Exam Grades of Students at The University of Southern Mississippi. The University of Southern Mississippi.

Wina Sanjaya. 2013. Penelitian Pendidikan, Jenis, Metode dan Prosedur. Jakarta: Kharisma Putra Utama.

Zulkardi. 2006. Formative Evaluation: What, Why, When, and How. [online], tersedia: http://www.oocities.org/zulkardi/books.html. 
Vol 1 No 22020 Desember 2020

Jurnal AlphaEuclidEdu

Received: 24/10/2020; Revised: 30/11/2020; Accepted: 06/12/2020

\title{
TANTANGAN BELAJAR MATEMATIKA DALAM MATERI ARITMATIKA SOSIAL PADA PESERTA DIDIK BERKEBUTUHAN KHUSUS
}

\author{
${ }^{1}$ Wulandari, Adinda Cintya, ${ }^{2}$ Sugiatno, ${ }^{3}$ Bistari \\ 1,2,3 Pendidikan Matematika FKIP Universitas Tanjungpura Pontianak \\ Email: adindacintyawulandari@gmail.com
}

\begin{abstract}
Advantages in mathematics education require high equality and strong support for all students and students from different backgrounds both social life and those in remote areas need to get equality in mathematics education. Learning challenges are basically caused by the emergence of students' obstacles in learning that students feel in the process of teaching and learning mathematics so that students are slow or unable to achieve their learning goals properly. In order to be able to spur the success of the mathematics learning process for SLB students, therefore we need basic facilities and infrastructure or supporting student success. The research aims to explore the cognitive factors that cause the challenges of learning mathematics in social arithmetic material in students with special needs. Descriptive method is used in this research. in the research subject consisted of 4 students of class VIII Extraordinary Middle School - B Dharma Asih Pontianak. The data obtained include student learning outcomes in social arithmetic material and student interviews. The results showed that $75 \%$ have not been able to work on social arithmetic problems so that the cognitive factors that cause the more dominant mathematical learning challenges affecting the four subjects are understanding and application.

Keywords: Children with Special Needs, Learning Challenges, Social Arithmetic.
\end{abstract}

\section{Pendahuluan}

Menurut para ahli di National Council Of Teachers Of Mathematics [NCTM] (2000: 12) menyatakan bahwa kelebihan dalam pendidikan matematika membutuhkan harapan/ ekspektasi yang tinggi serta dukungan/motivasi yang kuat bagi semua siswa. Siswa dengan latar belakang kehidupan sosial yang berbeda maupun yang tinggal di pelosok perlu mendapatkan kesetaraan pendidikan matematika. Kesempatan dan dukungan yang cukup harus dimiliki Semua siswa untuk belajar matematika tanpa memandang ciri-ciri persoalan, latar belakang atau hambatan fisik. pendidikan SLB adalah lembaga pendidikan yang tujuannya untuk membantu siswa yang mempunyai kelainan mental maupun fisik, perilaku dan interaksi sosial supaya bisa mengembangkan sikap, pengetahuan dan keterampilan yang dimilikinya sebagai pribadi maupun anggota masyarakat untuk mendapatkan hubungan timbal balik terhadap lingkungan sosial, budaya dan alam sekitar serta dapat melanjutkan pendidikan/ mengembangkan kemampuannya dalam dunia pekerjaan. Jenis pendidikan Luar Biasa mencakup: SLB-A untuk peserta didik Tunanetra, SMPLB-B untuk peserta didik Tunarungu, SLB-C untuk peserta didik Tunagrahita, SLB-D untuk peserta didik Tunadaksa, SLB-E untuk peserta didik Tuna Laras, dan SLB-G untuk peserta didik Tuna Ganda. Pada saat peneliti melaksanakan Program pra riset di SMPLB-B Dharma Asih Pontianak, peneliti melakukan observasi partisipatif di kelas 8 pada pembelajaran matematika dengan cara memberikan soal Aritmatika Sosial yang sudah lewat kepada 
Vol 1 No 22020 Desember 2020

Jurnal AlphaEuclidEdu

siswa di kelas tersebut. Hasil pengamatan peneliti mengenai soal yang diberikan kepada siswa ternyata siswa belum mampu mengerjakan soal secara tepat meskipun terdapat beberapa siswa yang mampu mengerjakan soal dengan benar.

Selain memberikan soal, peneliti juga mewawancara satu orang guru matematika yang mengajar siswa pada kelas tersebut dan fakta lapangan guru mengalami hambatan pada proses mengajar dikarenakan guru belum mampu menguasai bahasa isyarat yang digunakan siswa dalam sehari-hari meskipun guru yang ada di sekolah tersebut diberi buku panduan belajar bahasa isyarat. Anak tersebut membutuhkan metode, material, pelayanan dan peralatan yang khusus agar dapat mencapai perkembangan yang optimal. Karena anak-anak tersebut mungkin akan belajar dengan kecepatan yang berbeda dan juga dengan cara yang berbeda pula. Walaupun mereka memiliki potensi dan kemampuan yang berbeda dengan anak-anak secara umum, mereka harus mendapat perlakuan dan kesempatan yang sama. Hal ini dapat dimulai dengan cara penyebutan terhadap anak dengan kebutuhan khususTantangan belajar Pada dasarnya disebabkan karena adanya hambatan belajar yang dialami siswa dalam pembelajaran matematika sehingga siswa lambat atau tidak dapat mencapai tujuan pembelajaan dengan baik, bukan karena kebodohan siswa atau ketidakmampuannya dalam belajar, tetapi terdapat kondisis-kondisi tertentu yang membuat siswa tidak siap untuk belajar. Sekolah Luar Biasa (SLB) adalah sekolah khusus bagi anak usia sekolah yang memiliki "kebutuhan khusus".

Menurut Petunjuk Pelaksanaan Sistem Pendidikan Nasional Tahun 1993, Lembaga pendidikan SLB adalah lembaga pendidikan yang bertujuan membantu peserta didik yang menyandang kelainan fisik dan mental, perilaku dan sosial agar mampu mengembangkan sikap, pengetahuan dan keterampilan sebagai pribadi maupun anggota masyarakat dalam mengadakan hubungan timbal balik dengan lingkungan sosial, budaya dan alam sekitar serta dapat mengembangkan kemampuan dalam dunia kerja atau mengikuti pendidikan lanjutan. Satuan SLB disebut juga sistem segregasi yaitu sekolah yang dikelola berdasarkan jenis ketunaan namun terdiri dari beberapa jenjang. Adapun satuan pendidikan bagi anak berkebutuhan khusus terdiri dari jenjang TKLB, SDLB, SMPLB, SMALB, SMLB (Mangunsong, 1998). Jenis pendidikan Luar Biasa tersebut meliputi: SLB-A bagi peserta didik Tunanetra, SMPLB-B bagi peserta didik Tunarungu, SLB-C bagi peserta didik Tunagrahita, SLB-D bagi peserta didik Tunadaksa, SLB-E bagi peserta didik Tuna Laras, dan SLB-G bagi peserta didik Tuna Ganda. Disamping itu, pada saat ini telah berkembang pula sekolah untuk anak autis.Pada dasarnya guru yang mengajar di sekolah tersebut memang belum ada pendidikan khusus mengajar SLB oleh sebab itu guru juga menjadi penghambat siswa dalam proses pembelajaran matematika. Pada kenyataannya Penyebab penting lainnya kesulitan matematika pada siswa tersebut mungkin tidak ada kecocokan antara karakteristik pembelajaran, karakteristik masing-masing siswa dan instruksi yang mereka terima sehingga pada saat proses pembelajaran mereka tidak menerima dengan baik proses belajar dan tidak ada perbedaan antara proses belajar anak normal dan anak 
Vol 1 No 22020 Desember 2020

Jurnal AlphaEuclidEdu

berkebutuhan khusus meskipun sadar bahwa tidak adanya perbedaan dalam proses belajar namun dari pihak guru belum ada program untuk mengubah cara belajar yang seharusnya berbeda dengan anak pada umumnya, dalam kasus khusus seperti ini, instruksi harus disesuaikan dengan kebutuhan siswa. Selain itu, semua siswa dengan kesulitan matematika harusnya memerlukan spesifikasi Perhatian khusus.

Mengajar matematika dalam proses pembelajaran bukan hanya melibatkan guru/pengajar melinkan siswa yang secara langsung juga diperlukan faktor dukungan yang lain diantaranya: materi pelajaran yang layak, metode yang digunakan sesuai dengan standar, dan keadaan serta tempat proses pembelajaran yang mendukung. Pendidikan bagi anak berkebutuhan khusus banyak membawa manfaat bagi anak itu sendiri. Melalui pendidikan dapat mengetahui kemampuan yang dimiliki anak berkebutuhan khusus seterusnya akan dikembangkan yang akan berguna bagi kehidupannya karena banyak anak berkebutuhan khusus yang memiliki bakat yang tidak dimiliki oleh anak normal pada umumnya. Dapat menjadikan anak lebih disiplin dan mandiri sehingga tidak lagi bergantung pada orang lain dalam menjalani kehidupannya. Anak dapat bersosialisasi dan berkomunikasi dengan masyarakat sekitar sehingga anak merasa menjadi bagian dari masyarakat tersebut. Dapat mewujudkan seseorang yang memiliki kehidupan yang lebih baik di masa yang akan datang. Untuk memperoleh berhasilnya proses pembelajaran matematika terhadap siswa SLB diperlukan sarana dan prasarana baik pokok maupun pembantu/pelengkap. Hal ini dikarenakan harus mempertimbangkan kondisi yang ada pada siswa tunarungu yang mencakup kondisi fisik, mental, emosi araupun sosialnya. Siswa SLB sangat memerlukan pelayanan serta pendidikan yang lebih. Perlu diketahui bahwa belum ditemukan metode atau pendekatan jenis pendidikan serta cara yang dapat diberikan dalam pelayanan pendidikan untuk semua masalah yang tidak sama. Iniah alasan kenapa para guru diharuskan agar tetap aktif dan kreatif untuk memberikan pendidikan yang terbaik bagi siswa SLB pada umumnya sehingga mampu mengembangkan strategi atau metode

Menurut Drawing on Herscovics (1989) Hambatan kognitif adalah hambatan yang dihadapi dalam proses akuisisi pengetahuan baru. Mallet (2013: 152) menulis bahwa hambatan kognitif adalah "situasi di mana struktur mental yang ada sesuai untuk satu domain tetapi menyebabkan hambatan belajar di domain lain karena ketidakcocokan dengan situasi atau konsep baru". Jadi, ketika siswa bertemu dengan pengetahuan baru, pengetahuan mereka sebelumnya mungkin tidak kompatibel dengan yang baru, mengakibatkan konflik kognitif antara keduanya (Tall \& Vinner, 1981; Tall, 1991). Banyak dari hambatan kognitif ini muncul sebagai konsekuensi dari proses abstraksi yang terlibat dalam formalisasi konsep. Sebagai contoh, penelitian telah mengidentifikasi perbedaan antara definisi formal dari konsep batas dan gambar yang digunakan peserta didik dalam pikiran mereka ketika mereka bekerja dengannya, sering mengakibatkan ketidakcocokan antara gambar konsep individu dan definisi formal (Parameswaran, 2007; Tinggi \& Vinner, 1981). Semakin abstrak konsepnya, semakin banyak kesulitan konseptual yang dialami siswa dan semakin sedikit mereka mampu 
Vol 1 No 22020 Desember 2020

Jurnal AlphaEuclidEdu

mengoordinasikan gambar konsep mereka dengan definisi konsep, menabur benih hambatan kognitif masa depan (Tall \& Schwarzenberger, 1978). Selain itu, seperti dibahas di atas, ketika disajikan dengan representasi simbolik dari batas, siswa sering menemukan membedakan antara proses menemukan batas dan nilai yang terkait dengan itu sulit (Kidron, 2008). Artinya, kegagalan melihat persamaan dan perbedaan antara keduanya memprovokasi hambatan kognitif. Secara umum, siswa cenderung memiliki pandangan proses dinamis tetapi tidak melihat objek statis batas, dengan konsekuensi bahwa mereka tidak dapat melihat interaksi antara keduanya (Bagni, 2005; Parameswaran, 2007; Williams, 1991). Juga, konsepsi spontan dan sebelumnya biasanya bertahan lama dalam pikiran siswa (Prezenioslo, 2004), menunjukkan bahwa konsepsi dan gambar yang terbentuk selama tahun sekolah menengah mereka dapat tetap bersama siswa melalui formalisasi yang diperkenalkan di universitas (Prezenioslo, 2004) dan bertahan bahkan di luar instruksi universitas yang dirancang untuk membantu siswa mengatasi kesulitan seperti itu (Szydlik, 2000). Dengan demikian, sifat abstrak dari konsep batas dan proses abstraksi terlibat di dalamnya 4 formalisasi, inkompatibilitas antara konsep gambar dan definisi konsep, batas yang diperoleh, pengetahuan sebelumnya terkait dengan konsep batas dan kata-kata yang terkait semua, sumber hambatan kognitif.

\section{Metode Penelitian}

Metode yang dipandang sesuai dalam penelitian ini adalah menggunakan metode deskriptif karena sesuai dengan permasalah yang akan dikaji, dikarenakan tujuan dari penelitian ini untuk mengetahui faktor kognitif penyebab tantangan belajar matematika materi Aritmatika Sosial pada peserta didik anak berkebutuhan khusus Kelas VIII di SMPLB-B Dharma Asih Pontianak. Studi kasus adalah bentuk penelitian yang digunakan dalam penelitian ini. Subjek penelitian ini yaitu 4 siswa kelas VIII Sekolah Menengah Pertama Luar Biasa - B Dharma Asih Pontianak. Dalam penelitian ini prosedur penelitian terdiri atas 3 tahap yaitu tahap persiapan, tahap pelaksanaan, dan tahap pembuatan laporan. Alat pengumpulan data yang digunakan pada penelitian ini adalah berupa tes tertulis berbentuk esay dan wawancara mendalam. Teknik analisis data dilakukan berdasarkan pada rumusan masalah yang dijawab. Dalam penelitian ini, peneliti ingin mengetahui dan mendapatkan informasi mengenai tantangan belajar matematika dalam materi Aritmatika Sosial pada anak berkebutuhaan khusus kelas VIII di SMPLB-B Dharma Asih Pontianak

\section{Hasil Penelitian dan Pembahasan}

\subsection{Hasil Penelitian}

Hasil penelitian yang sudah peneliti lakukan, didapat data yang dibutuhkan untuk mendeskripsikan tantangan belajar matematika pada anak berkebutuhan khusus yang meliputi hasil deskripsi data, analisis data tes, dan analisis data wawancara tantangan belajar matematika dalam materi aritmatika sosial pada anak berkebutuhan khusus. 
Vol 1 No 22020 Desember 2020

Jurnal AlphaEuclidEdu

Penelitian ini dilakukan dengan maksud untuk mengetahui tantangan belajar matematika pada anak berkebutuhan khusus pada materi aritmatika sosial yang melibatkan siswa pada tes tantangan belajar matematika. Dengan indikator yang hendak dicapai dalam pembelajaran yaitu dapat menentukan dan menyelesaikan masalah yang terkait denan dengan materi aritmatika sosial dalam kehidupan sehari-hari.

Pada awal pembelajaran, guru memberikan salam yang tertuju ke peserta didik dan menyuruh peserta didik untuk mempersiapkan alat tulis diatas meja. Kemudian guru menjelaskan materi aritmatika sosial sesuai dengan soal yang akan diberi peneliti. Selanjutnya guru memberikan contoh cara menentuan hasil untung rugi dalam penerapan sehari-hari. Pendidik memberikan contoh soal cerita, peserta didik diminta mencatat soal dibuku terlebih dahulu.peserta didik diajak bersama-sama mengerjakan contoh soal yang diberikan guru, setelah selesai menjelaskan soal pertama, guru memberikan contoh soal yang serupa dengan sebelumnya dan guru meminta peserta didik $\mathrm{AB}$ untuk mengerjakannya. $\mathrm{AB}$ tidak ada mengalami kesulitan dalam mengerjakan soal tersebut hanya saja VR sulit untuk menjelaskan cara penyelesaiannya. Selanjutnya mengerjakan soal kedua guru meminta VR untuk mengerjakan soal tersebut. VR mendapatkan hasil pengurangan dengan benar dan tepat tetapi sulit untuk menjelaskan kembali penyelesaiannya. Untuk soal ketiga guru melemparkan soal ke peserta didik SS, tetapi SS mengalami kesulitan dalam mengerjakan soal ketiga sehingga guru melemparkan pertanyaan ke peserta didik yang lain. Setelah ketiga soal selesai dikerjakan, guru meminta peserta didik untuk menulis kembali jawaban yang ada dipapan tulis.

Berdasarkan hasil pengamatan, peserta didik kurang aktif atau bahkan tidak ada yang mau beertanya kepada guru jika mengalami kesulitan belajar. Ketika guru bertanya, peserta didik VR aktif menjawab pertanyaan guru meskipun mengalami hambatan dalam wicara. Untuk peserta SS, terlihat sangat jelas bahwa peserta didik tersebut sama sekali tidak dapat menerima pembelajaran dengan baik. Dari 4 peserta didik, 3 peserta didik belum mencapai KKM yaitu 65 . Jadi $75 \%$ peserta didik belum mencapai KKM dan mengalami hambatan belajar. Berdasarkan klasifikasi tersebut, peneliti memilih 3 subjek terpilih langkah selanjutnya adalah mendeskripsi jawaban hasil penyelesaian soal

Tabel 1. Skor dan Nilai Tes Tantangan Belajar Matematika Pada Anak Berkebutuhan Khusus

\begin{tabular}{|c|c|c|c|c|c|c|c|}
\hline \multirow{2}{*}{ No } & \multirow{2}{*}{$\begin{array}{l}\text { Kode } \\
\text { Nama }\end{array}$} & \multicolumn{3}{|c|}{ Skor setiap soal } & \multirow{2}{*}{$\begin{array}{l}\text { Jumlah } \\
\text { Skor }\end{array}$} & \multirow{2}{*}{ Nilai } & \multirow{2}{*}{ Kriteria } \\
\hline & & 1 & 2 & 3 & & & \\
\hline 1 & VR & 9 & 4 & 3 & 18 & 80 & Tuntas \\
\hline 2 & $\mathrm{AB}$ & 5 & 3 & 2 & 11 & 50 & $\begin{array}{l}\text { Belum } \\
\text { Tuntas }\end{array}$ \\
\hline 3 & HRS & 4 & 4 & 1 & 10 & 45 & $\begin{array}{l}\text { Belum } \\
\text { Tuntas }\end{array}$ \\
\hline 4 & SS & 4 & 4 & 2 & 11 & 50 & $\begin{array}{l}\text { Belum } \\
\text { Tuntas }\end{array}$ \\
\hline
\end{tabular}


Vol 1 No 22020 Desember 2020

Jurnal AlphaEuclidEdu

\subsection{Pembahasan}

Berdasarkan hasil analisa data yang telah dipaparkan pada hasil penelitian, akan dilakukan pembahasan lebih lanjut terhadap data-data tersebut. untuk mengetahui faktor kognitif apakah yang menjadi tantangan belajar matematika dalam materi aritmatika sosial pada anak berkebutuhan khusus di SMPLB-B Dharma Asih Pontianak merupakan tujuan dari penelitian ini. Berikut ini akan dipaparkan mengenai bagaimana mengetahui faktor kognitif yang menjadi tantangan belajar matematika dalam materi aritmatika sosial.

Subjek VR pada soal nomor 1 bagian a, subjek VR sudah menjawab dengan benar dan pada bagian $b$ VR juga menjawab hasil akhir dengan benar namun VR tidak menuliskan rumus. Pada soal nomor 2 VR menjawab kurang tepat karena salah menuliskan rumus. Pada soal nomor 3 VR tidak bisa mengerjakan penyelesaiannya namun VR sudah menuliskan nilai diketahui dan ditanya dengan benar. Berdasarkan hasil wawancara, tampak bahwa subjek mengalami hambatan dalam mengerjakan soal dikarenakan subjek kurang teliti dalam mengerjakan soal. Kemudian subjek tidak mengerti isi soal menggunakan bruto, netto dan tara, hal ini menunjukan bahwa VR memang mengalami hambatan dalam soal cerita. Penyebab tersebut adalah kurangnya pemahaman VR tentang kalimat matematika dan dari pihak guru jarang memberikan soal dalam bentuk cerita. Dari hasil tes dan wawancara dapat disimpulkan bahwa tantangan belajar matematika pada kognitif 1 subjek VR yaitu daya ingat yang lemah membuat subjek lambat untuk mencapai hasil yang diharapkan, kemudian pada kognitif 2 subjek VR belum memahami konsep dasar materi arimatika sosial dan lambatnya menangkap materi yang dijelaskan, sehingga membuat subjek merasa kesulitan dalam menentukan hasil akhir, yang terakhir pada kognitif 3 subjek VR belum mampu menerapkan materi yang dipaparkan dikarenakan kurangnya latihan yang diberikan guru sehingga subjek belum mampu mengaplikasikan penyelesaian suatu masalah matematika yang diberikan.

Subjek AB Pada soal nomor 1 bagian a Subjek AB sudah menjawab dengan benar namun pada bagian b subjek $\mathrm{AB}$ belum tepat dalam menyelesaikan soal. Pada soal nomor $2 \mathrm{AB}$ menjawab kurang tepat namun $\mathrm{AB}$ sudah dapat menentukan nilai yang diketahui dan yang ditanyakan pada soal. Untuk soal nomor 3 AB tidak dapat menentukan dan menyimpulkan hasil dengan benar belum bisa menyelesaikan model matematika sesuai dengan prosedur dengan tepat tetapi dapat menuliskan apa yang diketahui dan ditanya dengan benar. Berdasarkan wawancara peneliti, tampak subjek tidak mengerti isi soal menggunakan bruto, netto dan tara. Kemudian peneliti menjelaskan kembali kepada $\mathrm{AB}$ bagaimana cara menentukan tara dalam soal cerita tersebut. Hal ini menunjukan bahwa $\mathrm{AB}$ memang mengalami hambatan dalam soal cerita. Penyebab tersebut adalah kurangnya pemahaman AB tentang kalimat matematika dan dari pihak guru jarang memberikan soal dalam bentuk cerita. AB juga mengalami hambatan pada soal nomor $1 \mathrm{~b}$ sehingga peneliti meminta $A B$ untuk membaca dan mengerjakan kembali soal tes nomor $1 \mathrm{~b}$. Berdasarkan hasil wawancara, tampak bahwa 
Vol 1 No 22020 Desember 2020

Jurnal AlphaEuclidEdu

subjek mengalami hambatan dalam mengerjakan soal dikarenakan subjek kurang teliti dalam mengerjakan soal. Dari hasil tes dan wawancara dapat disimpulkan bahwa tantangan belajar matematika pada kognitif 1 subjek $\mathrm{AB}$ yaitu kemampuan mengingat yang lemah membuat subjek lambat untuk mencapai hasil yang diharapkan, kemudian pada kognitif 2 subjek AB mampu memahami konsep dasar materi arimatika sosial dan walaupun lambat menangkap materi yang dijelaskan, sehingga membuat subjek mampu menentukan hasil akhir, yang terakhir pada kognitif 3 subjek $A B$ belum mampu menerapkan materi yang dipaparkan dikarenakan kurangnya latihan yang diberikan guru sehingga subjek belum mampu mengaplikasikan penyelesaian suatu masalah matematika yang diberikan.

Subjek HRS Pada soal nomor 1 bagian a subjek HRS sudah benar menjawab dengan benar namun pada bagian b subjek HRS belum tepat dalam menyelesaikan soal. Pada soal nomor 2 HRS menjawab kurang tepat namun HRS sudah menentukan nilai diketahui serta yang ditanaya pada soal. Pada soal nomor 3 HRS belum dapat menyelesaikan konsep matematika sesuai dengan prosedur soal dengan tepat namun HRS dapat menentukan nilai diketahui dan ditanya dengan tepat. Berdasarkan hasil wawancara, tampak bahwa subjek mengalami hambatan dalam operasi pengurangan. Dalam wawancara, peneliti menjelaskan kepada HRS bagaimana cara menyelesaikan operasi pengurangan menggunakan metode jual beli. Ketika peneliti menanyakan apakah harga beli lebih tinggi atau rendah dari harga jual, HRS menjawab dengan cara menebak. Hal ini menunjukan bahwa HRS memang kurang memahami operasi pengurangan menggunakan metode jual beli. Dari hasil tes dan wawancara dapat disimpulkan bahwa tantangan belajar matematika pada kognitif 1 subjek HRS yaitu daya ingat yang lemah membuat subjek lambat untuk mencapai hasil yang diharapkan, kemudian pada kognitif 2 subjek HRS belum memahami konsep dasar materi arimatika sosial dan lambatnya menangkap materi yang dijelaskan, sehingga membuat subjek merasa kesulitan dalam menentukan hasil akhir, yang terakhir pada kognitif 3 subjek HRS belum mampu menerapkan materi yang dipaparkan dikarenakan kurangnya latihan yang diberikan guru sehingga subjek belum mampu mengaplikasikan penyelesaian suatu masalah matematika yang diberikan.

Subjek SS Pada soal 1 bagian a subjek SS sudah menjawab dengan benar namun pada bagian b subjek SS belum dapat memberikan jawaban dengan benar. Pada soal nomor 2 subjek SS belum tepat memberikan hasil akhir namun sudah menajwab dengan benar nilai diketahui dan ditanya serta konsep matematika yang benar. Pada soal nomor 3 subjek SS hanya dapat menuliskan nilai diketahui dan ditanya namun tidak dapat menyelesaikan konsep matematika sesuai prosedur dan tidak dapat menjawab hasil akhir. Berdasarkan hasil wawancara diatas, terlihat bahwa subjek masih belum paham dengan konsep matematika sehingga SS mengalami hambatan dalam menyelesaikan hasil akhir.

Dari hasil tes dan wawancara dapat disimpulkan bahwa tantangan belajar matematika pada kognitif 1 subjek SS yaitu daya ingat yang lemah membuat subjek 
Vol 1 No 22020 Desember 2020

Jurnal AlphaEuclidEdu

belum mampu mencapai hasil yang diharapkan, kemudian pada kognitif 2 subjek SS belum memahami konsep dasar materi arimatika sosial dan lambatnya menangkap materi yang dijelaskan, sehingga membuat subjek merasa kesulitan dalam menentukan hasil akhir, yang terakhir pada kognitif 3 subjek SS belum mampu menerapkan materi yang dipaparkan dikarenakan kurangnya latihan yang diberikan guru sehingga subjek belum mampu mengaplikasikan penyelesaian suatu masalah matematika yang diberikan. Jadi berdasarkan tes soal dan wawancara peneliti dengan subjek VR, AB, HRS, dan SS dapat disimpulkan bahwa faktor kognitif yang menjadi penyebab tantangan belajar matematika yang lebih dominan memepengaruhi ketiga subjek tersebut adalah pemahaman dan penerapan.

Faktor-faktor tersebut menjadi penyebab tantangan belajar siswa, siswa sangat sulit untuk mengingat materi yang telah dipelajari, sehingga guru harus mengulang materi yang telah diajarkan, kemudian dalam memahami isi soal perlu waktu lama karena daya tangkap yang lambat membuat siswa lambat dalam berfikir selain itu pengetahuan konsep dasar materi bilangan bulat yang membuat siswa sulit untuk memahami materi aritmatika sosial. Hal ini menunjukan bahwa pembelajaran matematika yang dialami siswa selama ini tidak bermakna. Menurut Ausubel (Dahar, 1996:112) pembelajaran bermakna merupakan suatu proses mengaitkan informasi baru pada konsep-konsep relevan yang terdapat dalam struktur kognitif seseorang. Proses belajar tidak sekedar menghafal konsep-konsep dan fakta-fakta belaka, namun berusaha menghubungkan konsep-konsep tersebut untuk menghasilkan pengetahuan, pemahaman, dan penerapan. Faktor kognitif yang dialami pada siswa sudah sepatutnya dijadikan bahan refleksi bagi guru untuk memperbaiki proses pembelajaran berikutnya, dalam memperbaiki proses pembelajaran matematika tentunya terkait dengan kebutuhan siswa yang didalamnya termuat potensi yang mereka miliki.

\section{Kesimpulan}

Dari hasil dan pembahasan Penelitian ini dapat disimpulkan faktor kognitif yang menjadi penyebab tantangan belajar matematika dalam materi aritmatika sosial pada peserta didik berkebutuhan khusus, yaitu: (1) faktor pengetahuan, lemahnya daya ingat siswa membuat guru harus mengulang lagi materi yang sudah diajarkan; (2) faktor pemahaman, dalam memahami isi soal perlu waktu lama karena daya tangkap yang lambat membuat siswa lambat dalam berfikir; (3) faktor penerapan, ketidakmampuan menerima perubahan soal lama ke soal baru membuat siswa sulit untuk mengaplikasikan penyelesaian dengan cara yang berbeda

\section{Referensi}

Barbara, Arikunto, Suharsimi. 2010. Prosedur Penelitian Suatu Pendekatan Praktik. Jakarta: Rineka Cipta.

Cornu, B. (1991). Limit In 30/05/2012.O. Tall (Ed), Advanced Mathematical Thinking (pp. 153-166). Dordrecht : Kluwer Academic Publisher 
Vol 1 No 22020 Desember 2020

Jurnal AlphaEuclidEdu

Calhoun, J. F. 1990. Psikologi tentang Penyesuaian dan Hubungan Kemanusiaan. (Terjemahan Ny. R. S. Satmoko). Semarang: IKIP Press.

Darmadi, Hamid. 2014. Metode Penelitian Pendidikan dan Sosial. Bandung: Alfabeta.

Depdiknas. (2005). Materi Pelatihan terintegrasi Matematika. Jakarta: Depdiknas Direktorat Jenderal Pendidikan dasar dan Menengah Direktorat Pendidikan Lanjutan Pertama.

riz Achmad Haryono. 2012. Statistik Psikologi (Online). (https://www.scribd.com/collections/3711378/Statistic-Psikologi), diakses 24 Juni 2019

Hallahan dan Kauffman (1982). Klasifikasi Ketunarunguan.

Jamila K.A. Muhammad. (2008) Special Education for Special Children. Bandung: Hikmah.

Kemendikbud, 2015, Pedoman Penilaian SDLB, SMPLB, SMALB, Jakarta : Kemendikbud RI

Kemendikbud. 2013. Matematika Kelas VIII SMP/MTs. Jakarta: Kementerian Pendidikan dan Kebudayaan Republik IndonesiaMillles \& Huberman. (1992). Analisis data kualitatif. Jakarta: UII Press.

Moores Donald F (1981). Education the deaf (Psychology principle and practices) HougtohbMiflin Company. Boston.

Moleng, Lexy J. 2013. Metode Penelitian Kualitatif Edisi Revisi. Bandung: PT. Remaja Rosdakaya.

Muhammad Soleh. (1998). Pokok-pokok pengajaran matematika sekolah. Jakarta: Pusat Perbukuan Bagian proyek Pengembangan Buku dan Minat Baca.

Mulyadi. (2010). Diagnosis Kesulitan Belajar \& Bimbingan terhadap Kesulitan Belajar Khusus. Yogyakarta: Nuha Litera.

Nazir, Moh. 2009. Metode Penelitian. Jakarta: Ghalia Indonesia.

NCTM. (2000). Principle and Standard for School Mathematics. Reston, Virginia: The National Council of Mathematics of Teacher of Mathematics, Inc.

Sugihartono, dkk. 2007. Psikologi Pendidikan. Yogyakarta: UNY Press.

Sugiyono, 2012. Memahami Penelitian Kualitatif. Bandung: Alfabeta.

Poerwandari, E. K. 1998. Pendekatan Kualitatif dalam Penelitian Psikologi. Jakarta: Lembaga Pengembangan Sarana dan Pendidikan Psikologi

Xin, Y. P., \& Jitendra, A. K. (1999). The effects of instruction in solving mathematical word problems for students with learning problems: A meta-analysis. The Journal of Special Eduation, 32, 207-225. 
Vol 1 No 22020 Desember 2020

Jurnal AlphaEuclidEdu

Received: 21/10/2020; Revised: 30/11/2020; Accepted: 06/12/2020

\title{
POTENSI BERPIKIR KRITIS SISWA DALAM MENYELESAIKAN MASALAH PADA MATERI TRIGONOMETRI
}

\author{
1*Halimatussa'diah, ${ }^{2}$ Sugiatno, ${ }^{3}$ Ijuddin, Romal \\ 1,2,3Pendidikan Matematika FKIP Universitas Tanjungpura Pontianak \\ Email: halimatussadiah961@gmail.com
}

\begin{abstract}
Mathematics learning has an essential role in forming and developing students' critical thinking skills. It is in line with the objectives of learning mathematics, which shows a logical, critical, analytical, careful, and thorough, responsible, responsive, and not easily give up in solving problems. Mathematics taught to students has the aim to equip students to have critical abilities. But in reality, the implementation of mathematics learning in schools has not been able to train students' critical thinking skills. This study aims to describe and find out the potential of students' critical thinking in solving problems in trigonometry in high school. The research method used in this research is descriptive with exploratory research. The subjects in this study were 30 subjects. Based on the results of this study, it was found that the potential for students' critical thinking in solving trigonometry problems was medium. Potential students' critical thinking is categorized as being because students have not been able to understand the problem displayed correctly, students have difficulty in giving arguments or reasons for the answers they have stated, students cannot identify and choose relevant information because of the available mathematical models, students have difficulty in giving questions to the information displayed.

Keyword: Critical Thinking, Potential, Trigonometry
\end{abstract}

\section{Pendahuluan}

Pada dasarnya setiap manusia memiliki banyak potensi di dalam dirinya hanya saja potensi tersebut tidak dilatih atau tidak dikembangkan lagi hingga menjadi sebuah kemampuan. Kemampuan yang terdapat di dalam diri manusia yang dapat dikembangkan lagi menjadi lebih baik dengan sarana dan prasarana yang tepat dan baik dapat disebut dengan potensi (Habsari : 2005). Sedangkan menurut Pihadhi (Muchlisin: 2013) potensi bisa dikatakan sebagai kekuatan, energi atau kemampuan terpendam yang dimiliki manusia yang belum dimanfaatkan secara optimal.

Satu diantara potensi yang dimiliki oleh setiap manusia yaitu berpikir kritis. Berpikir kritis merupakan salah satu kemampuan berpikir tingkat tinggi (higher order thinking). Glaser berpendapat bahwa berpikir kritis merupakan kegiatan berpikir secara mendalam yang berhubungan dengan masalah dan hal-hal yang berada dalam jangkauan pengalaman seseorang yang dalam penyelesaiannya menggunakan metode pemeriksaan dan penalaran yang logis (Fisher, 2008:3).

Menurut Gokhale (Heris, Euis, dan Utari, 2017) mendefinisikan istilah berpikir kritis sebagai berpikir yang melibatkan kegiatan menganalisis, mensintesa, dan mengevaluasi konsep. Dalam berpikir kritis terlibat kegiatan memanipulasi data-data dan informasi yang ada menjadi lebih bermakna. Berpikir kritis adalah sebuah aplikasi untuk membuat alasan yang cermat dalam menentukan apakah suatu pernyataan itu benar atau tidak dan dapat mengevaluasi pernyataan tersebut (Richard dan Brooke, 2008). 
Vol 1 No 22020 Desember 2020

Jurnal AlphaEuclidEdu

Received: 21/10/2020; Revised: 30/11/2020; Accepted: 06/12/2020

Berdasarkan uraian para ahli dapat diketahui bahwa potensi berpikir kritis merupakan kemampuan dasar yang dimiliki manusia, kemampuan untuk menganalisis, membedakan, mencari hubungan dan dapat membuat argumen yang cermat untuk menentukan apakah suatu pernyataan tersebut benar atau tidak serta dapat mengevaluasi pernyataan tersebut. Keterampilan berpikir kritis merupakan keterampilan yang sangat penting untuk dikuasai oleh siswa agar siswa terampil dalam menyusun sebuah argument dan memeriksa kredibilitas sebuah sumber dalam membuat keputusan. Salah satu alat untuk mengembangkan kemampuan berpikir siswa yaitu, dengan pembelajaran matematika.

Pembelajaran matematika berperan penting dalam membentuk dan mengembangkan kemampuan berpikir kritis karena sejalan dengan tujuan pembelajaran matematika. Adapun salah satu tujuan pembelajaran matematika yaitu menunjukkan sikap analitis, kritis, logis, teliti, cermat, bertanggung jawab, responsive, dan tidak mudah menyerah dalam memecahkan masalah (Permendiknas, 2016). Pelajaran matematika yang diberikan di sekolah bertujuan untuk membekali siswa memiliki kemampuan kritis. Namun kenyataannya, melatih kemampuan berpikir kritis dalam kegiatan pembelajaran matematika di sekolah belum sepenuhnya terlaksana dengan baik Sampai saat ini pengembangan kemampuan berpikir kritis siswa masih relatif rendah.

Berdasarkan penelitian yang dilakukan Octavia (2015) kamampuan berpikir kritis siswa ditinjau dari aspek interpretation pada indikator mengklarifikasi maksud tegolong dalam kategori masih rendah dengan presentase $55,13 \%$. Sedangkan pada penelitian yang sejalan dengan Octavia yaitu kemampuan berpikir kritis siswa ditinjau dari aspek explanation dalam menyelesaikan masalah perbandingan di SMP yang dilakukan Feridia (2017) pada indikator menyajikan argumen tergolong dalam kategori sedang dengan presentase $41,35 \%$.

Satu diantara materi yang dapat mengembangkan potensi berpikir kritis siswa adalah trigonometri. Berdasarkan kurikulum 2013, trigonometri merupakan salah satu materi matematika peminatan yang diberikan di SMA kelas X IPA dan kelas XI IPA bahkan trigonometri masih dipelajari sampai kelas XII IPA. Selain menjadi menjadi mata pelajaran di sekolah trigonometri juga merupakan materi matematika yang banyak diterapkan dalam kehidupan sehari-hari. Mengingat pentingnya belajar trigonometri siswa diharapkan mampu menguasai materi dengan benar dan melalui materi trigonometri siswa diharapkan mampu mengembangkan potensi berpikir kritis yang dimilikinya. Namun kenyataan di lapangan masih banyak siswa kebingungan dalam menyelesaikan soal trigonometri yang diberikan.

Berdasarkan hasil pengamatan peneliti pada Praktek Pengalaman Lapangan (PPL) ketika guru menanyakan pada siswa. Berapa jumlah besaran pada segitiga? hampir semua siswa di dalam kelas menjawab $180^{\circ}$. Lalu guru menggambar 3 buah segitiga kecil, sedang 
Vol 1 No 22020 Desember 2020

Jurnal AlphaEuclidEdu

Received: 21/10/2020; Revised: 30/11/2020; Accepted: 06/12/2020

dan besar. Kemudian guru bertanya kembali Kira-kira jumlah besaran sudut pada segitiga kecil berapa? Pada segitiga sedang berapa? Pada segitiga yang besar berapa? ada beberapa orang siswa menjawab $45^{\circ}, 90^{\circ}$, dan $180^{\circ}$ dari jawaban siswa tersebut diketahui bahwa beberapa siswa terkecoh pada ukuran segitiga dalam menjawab jumlah besaran sudut pada segitiga. Untuk memperkuat data mengenai masalah yang terjadi pada siswa, peneliti melakukan pra-riset. Berdasarkan hasil pra-riset yang dilakukan pada 5 siswa kelas hanya 2 dari 5 siswa tersebut yang dapat menjawab soal dengan nilai di atas rata-rata yang telah ditentukan oleh sekolah. Berdasarkan hasil pekerjaan siswa diketahui bahwa 3 siswa tersebut tidak tepat dalam menyatakan dan tidak dapat menjelaskan dengan benar padahal menyatakan dan menjelaskan merupakan salah satu indikator berpikir kritis.

Pra-riset yang dilakukan belum menggunakan sampel yang menggambarkan potensi berpikir kritis seluruh siswa. Terutama untuk siswa yang ada di SMA Negeri 1 Sungai Ambawang belum pernah menjadi sampel dalam studi mengenai berpikir kritis. Karena peneliti penasaran mengenai potensi berpikir kritis siswa dalam menyelesaikan masalah trigonometri di SMA Negeri 1 Sungai Ambawang maka maksud dari riset ini adalah untuk mendeskripsikan potensi berpikir kritis siswa dalam menyelesaikan masalah pada materi trigonometri di Sekolah Menengah Atas.

Kemampuan dasar berpikir kritis siswa dapat dilihat dengan indikator-indikator yang telah dikemukan oleh beberapa ahli, salah satunya menurut Richard Parker dan Brooke Noel Moore (2008 : 5) terdapat tiga indikator dasar berpikir kritis, yaitu : 1). claim merupakan elemen dasar berpikir kritis, claim adalah suatu pernyataan yang kita ucapkan dengan tegas atau yang dituangkan dalam tulisan untuk menyampaikan informasi, mengekspresikan pendapat kita atau kepercayaan. Pernyataan juga dapat diartikan sebagai sikap seseorang terhadap suatu informasi; 2). Argumen adalah alasan logis yang mendukung sebuah pernyataan untuk menentukan kebenaran suatu pernyataan dan dapat diterima oleh banyak orang, argumen unsur terpenting dalam pemikiran kritis karena kesimpulan dari argumenlah yang dapat menyatakan posisi dari suatu pernyataan. Argumen yang baik adalah argumen yang dapat dipertanggung jawabkan dan beralasan (Jack, Stuart dan Mary, 2012:06); 3). Issue adalah pertanyaan yang dapat diajukan oleh seseorang terhadap suatu informasi yang baru diketahui atau informasi yang sudah ia ketahui namun disajikan dalam bentuk yang berbeda terlepas dari pernyataan tersebut benar atau salah. Isu dapat juga diartikan sebagai pertanyaan baru yang dapat muncul setelah seseorang melihat atau mendapat informasi.

\section{Metode Penelitian}

Metode deskriptif adalah metode yang digunakan dalam penelitian ini. Metode deskriptif merupakan metode penelitian yang menggambarkan atau menginterpretasikan 
Vol 1 No 22020 Desember 2020

Jurnal AlphaEuclidEdu

Received: 21/10/2020; Revised: 30/11/2020; Accepted: 06/12/2020

objek sesuai dengan apa yang terjadi (Sukardi, 2013). Sementara itu menurut Nazir (2017 : 43) untuk meneliti suatu kelompok manusia atau suatu objek dalam suatu set kondisi atau sistem pemikiran ataupun suatu kelas peristiwa pada masa sekarang, metode deskriptif merupakan metode yang sangat cocok untuk digunakan dalam penelitian ini. Pendekatan dalam penelitian ini adalah mix methods. Mix methods merupakan metode penelitian yang menggabungkan metode penelitian kualitatif dan kuantitatif dalam suatu kegiatan penelitian (Sugiyono, 2011).

Berdasarkan masalah dalam penelitian ini, penelitian eksploratif adalah bentuk penelitian yang digunakan peneliti dalam penelitian ini. Penelitian eksploratif adalah penelitian yang menggambarkan apa yang sedang terjadi yang berhubungan dengan siapa, kapan dan dimana, ataupun yang berhubungan dengan karakteristik suatu gejala atau masalah sosial. Pertanyaan tersebut dimaksudkan untuk mengetahui suatu gejala atau peristiwa yang terjadi. Pertanyaan tersebut merupakan pendalam terhadap berbagai hal yang berhubungan dengan gejala yang ada. Pendalam yang dilakukan tidak sistematis dan terkontrol yang artinya tidak berdasarkan hipotesis dan sampel dalam jumlah yang pasti (Mudjiyanto, 2018).

Menurut Given untuk mencari faktor penting penyebab timbulnya kesukaran dapat menggunakan penelitian eksplorasi. Penelitian eksplorasi dapat digunakan sebagai langkah awal untuk merumuskan persoalan yang ada dimana pemecahan persoalan tersebut, dapat dipecahkan menggunakan jenis penelitian lainnya, Karena penelitian eksplorasi hanya mencari ide atau hubungan baru, sehingga tidak ada suatu perencanaan yang formal, jadi pelaksanaannya tergantung pada kepandaian dari peneliti (Mudjiyanto, 2018). Subjek pada penelitian ini adalah 30 siswa kelas XI IPA 1 SMA Negeri 1 Sungai Ambawang yang telah mempelajari materi Trigonometri. Objek dalam penelitian ini adalah berpikir kritis siswa dilihat dari tiga indikator, yaitu: claim, argument dan issue dalam menyelesaikan soal trigonometri.

Alat pengumpul data yaitu tes tertulis dan wawancara. Tahapan penelitian terdiri dari tiga tahapan, yaitu:

Tahap Persiapan

Tahapan yang dilaksanakan dalam tahap ini yaitu: (1). Melakukan pra-riset. Pra-riset dilakukan untuk studi pendahuluan yaitu memberikan tes kepada beberapa siswa di sekolah tersebut. Menyusun desain penelitian; (2). Membuat instrumen penelitian berupa kisi-kisi soal, soal tes berpikir kritis siswa, alternatif jawaban, pedoman penskoran dan pedoman wawancara; (3). Seminar desain penelitian; (4). Memperbaiki desain penelitian berdasarkan hasil seminar; (4). Melakukan validitas instrument; (5). Memperbaiki instrumen berdasarkan hasil validitas; (6). Melakukan uji coba instrument; (7). Menganalisis data hasil uji coba; (8). Memperbaiki instrumen penelitian berdasarkan hasil uji coba soal; (8). 
Vol 1 No 22020 Desember 2020

Jurnal AlphaEuclidEdu

Received: 21/10/2020; Revised: 30/11/2020; Accepted: 06/12/2020

Meminta izinan untuk melakukan penelitian; (9). Menentukan waktu pelaksanaan penelitian dengan berkonsultasi pada guru matematika di SMA Negeri 1 Sungai Ambawang.

Tahap Pelaksanaan

Tahapan yang dilakukan pada tahap ini yaitu: (1). Memberikan tes perpikir kritis dalam menyelesaikan masalah pada materi trigonometri kepada siswa kelas XI IPA 1 ; (2). Menganalisis hasil tes yang telah dikerjakan siswa; (3). Memilih beberapa siswa berdasarkan hasil tes untuk diwawancarai; (4). Melakukan wawancara mendalam pada siswa yang telah ditentukan berdasarkan hasil tes. Wawancara siswa dilakukan untuk menggali informasi lebih dalam mengenai potensi berpikir kritis siswa.

Tahap Akhir

Tahapan yang dilaksanakan pada tahap ini yaitu; (1) Mengumpulkan data penelitian berupa tes berpikir kritis dan wawancara; (2). Melakukan analisis jawaban siswa; (3). Melakukan analisis data hasil wawancara; (4). Mendeskripsikan hasil analisis tes berpikir kritis dan hasil wawancara; (5). Membuat kesimpulan dan saran; (6). Menyusun skripsi.

\section{Hasil Penelitian dan Pembahasan}

\subsection{Hasil Penelitian}

Untuk memaparkan potensi berpikir kritis siswa dalam menyelesaikan soal trigonometri berdasar tiga indikator, berdasarkan pada hasil penelitian yang telah dilaksanakan, sehingga didapatkanlah data yang diperlukan dalam menjawab rumusan masalah pada penelitian ini yakni: menyatakan hasil, Menyajikan argumen dan menyajikan pertanyaan mengenai informasi yang disajikan pada materi trigonometri oleh siswa SMA Negeri 1 Sungai Ambawang. Berikut akan dijabarkan terkait hasil penelitian dan pembahasan. Adapun tujuan dalam penelitian ini yakni untuk mendeskripsikan potensi berpikir kritis siswa dalam menyelesaian masalah pada materi trigonometri di Sekolah Menengah Atas. Sebanyak 30 siswa kelas XI IPA 1 SMA Negeri 1 Sungai Ambawang menjadi subjek dalam penelitian ini yang telah mempelajari materi Trigonometri, dengan jumlah soal 3 dan jenis soal essay. Tiap soal memiliki skor maksimal 6 dengan rentang skor 0 - 4 untuk indicator claim, $0-8$ untuk indicator argumen dan 0-6 untuk indicator issue.

\section{Tabel 1}

Hasil Penskoran Potensi Berpikir Kritis Siswa Dalam Menyelesaikan Masalah Pada Materi

Trigonometri di Sekolah Menengah Atas Tahun Ajaran 2019/2020.

\begin{tabular}{|c|c|c|c|c|}
\hline Indikator & Claim & $\begin{array}{c}\text { Argume } \\
\text { n }\end{array}$ & Issue & \multirow{2}{*}{ Jumlah } \\
\cline { 1 - 4 } Nomor Soal & $1 \& 2$ & $1 \& 2$ & 3 & \\
\hline
\end{tabular}


Vol 1 No 22020 Desember 2020

Jurnal AlphaEuclidEdu

Received: 21/10/2020; Revised: 30/11/2020; Accepted: 06/12/2020

\begin{tabular}{|c|c|c|c|c|}
\hline Jumlah Skor & 100 & 163.5 & 44 & 307.5 \\
\hline Skor Maksimum & 120 & 240 & 180 & 540 \\
\hline$\%$ & 2500 & 2043.75 & 733 & 1708.3 \\
\hline Rata-rata (\%) & 83 & 68 & 24 & 57 \\
\hline Kategori & Tinggi & Sedang & Rendah & Sedang \\
\hline
\end{tabular}

Berdasarkan tabel 1. diketahui bahwa potensi berpikir kritis siswa dalam menyelesaikan masalah pada materi trigonometri dikategorikan sedang dengan persentase $57 \%$. Sedangkan untuk masing- masing indikator berbeda-beda yakni: tinggi untuk indicator claim, sedang untuk indicator argumen dan rendah untuk indicator issue. 
Vol 1 No 22020 Desember 2020

Jurnal AlphaEuclidEdu

Received: 21/10/2020; Revised: 30/11/2020; Accepted: 06/12/2020

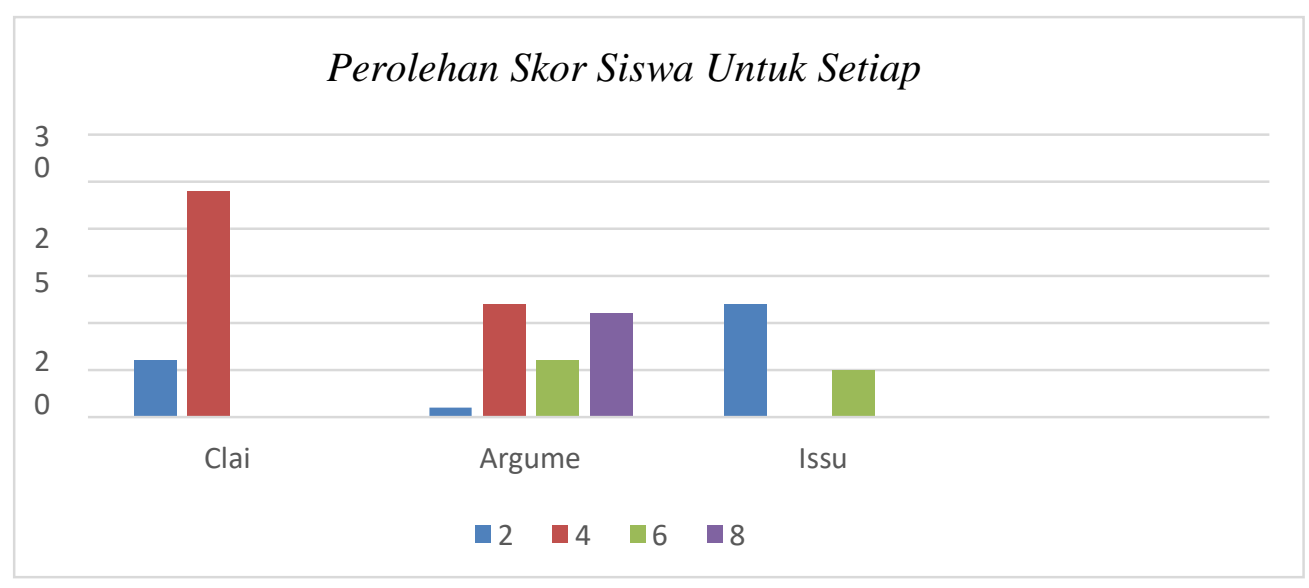

Berdasarkan diagram di atas diketahui bahwa pada indicator claim terdapat 6 siswa yang memperoleh skor 2 dan 24 siswa yang memperoleh skor 4 dengan rentang skor pada indicator claim adalah $0-4$. Pada indicator argumen terdapat 1 siswa yang memperoleh skor 2, 12 siswa yang memperoleh skor 4, 6 siswa yang memperoleh skor 6 dan 11 siswa yang memperoleh skor 8 dengan rentang skor pada indicator argumen 0 - 8. Pada indicator issue terdapat 12 siswa yang memperoleh skor 2 dan 5 siswa yang memperoleh skor 6 dengan rentang skor pada indicator issue adalah $0-6$.

\subsection{Pembahasan}

Potensi berpikir kritis siswa dalam menyelesaikan masalah pada materi trigonometri di sekolah menengah atas ini, peneliti mempunyai 3 indikator berpikir kritis, yaitu : claim, argumen, dan issue. Secara umum siswa kelas XI IPA 1 di SMA Negeri 1 Sungai Ambawang memiliki potensi berpikir kritis yang bisa dikategorikan sedang terlihat dari persentase rata-rata skor siswa yakni 57\%. Terdapat 4 siswa kategori tinggi, 15 siswa kategori sedang dan 11 siswa dengan kategori rendah. Dari 30 siswa terdapt 17 atau $56,67 \%$ siswa dapat mejawab semua soal yang telah diberikan meskipun ada beberapa siswa yang tidak dapat menjawab semua soal dengan benar. 15 siswa atau 50\% memperoleh skor 61-97 sedangkan 15 siswa lainnya memperoleh skor 28-56.

Berdasarkan hasil wawancara secara umum ditemukan bahwa berpikir kritis siswa dipengaruhi oleh beberapa factor, yaitu: pengalaman dan lingkungan. Hal ini sesuai dengan Skovsmose (2014) yang mengatakan bahwa masa depan ditentukan dengan banyak sekali parameter yang harus dilakukan dengan kondisi ekonomi, social-ekonomi, proses inklusi dan eksklusi, budaya, nilai-nilai dan tradisi, wacana public, dan rasisme. Selain itu, masa depan juga ditentukan melalui pengalaman orang tersebut. Hal ini adalah persiapan pendidikan matematika kritis untuk mengakui keragaman masa depan siswa dan untuk mengembangkan pendidikan matematika yang mungkin memberikan kemungkinan baru siswa. Sedangkan untuk masing-masing indikator tersebut siswa memperoleh skor berdeda-beda ada yang tinggi, sedang, dan rendah. Siswa dapat memperoleh skor tinggi, 
Vol 1 No 22020 Desember 2020

Jurnal AlphaEuclidEdu

Received: 21/10/2020; Revised: 30/11/2020; Accepted: 06/12/2020

sedang, dan rendah pada tes tersebut dipengaruhi oleh banyak faktor salah satunya pengalaman dan lingkungan belajar. Berikut akan dibahas mengenai proses berpikir kritis siswa berdasarkan indikator claim, argumen, dan issue.

Pada indikator claim peneliti memberikan 2 soal dengan soal yang berbeda. Berikut pembahasan dari indikator claim.

Hasil analisis pada soal nomor 1 dan 2 pada indikator claim ada 16 dari 30 siswa yang dapat menyatakan dengan benar. Sedangkan 14 siswa lainnya menyatakan soal nomor 1 atau nomor 2 saja yang benar. Banyak dari mereka salah dalam menyatakan soal nomor 2 . Setelah dilakukan wawancara kepada 3 siswa yang mendapat skor tinggi, sedang dan rendah pada indikator claim diketahui bahwa siswa yang memperoleh skor sedang salah menyatakan soal nomor 2 ia salah dalam menjumlahkan dan mengurangkan sudut pada segitiga $\mathrm{ABD}$, siswa yang memperoleh skor rendah salah dalam menggambarkan soal nomor 2 sehingga ia tidak dapat menyatakan soal nomor 2 benar atau tidak, sedangkan siswa yang memperoleh skor tinggi dapat menyatakan soal nomor 1 dan 2 dengan benar hanya saja dia menyatakan jumlah besaran sudut pada semua segitiga padahal yang ditanyakan hanya jumlah besaran sudut pada satu segitiga saja.

Siswa yang memperoleh skor tinggi tersebut saat ditanyakan ternyata dia sudah pernah mendapat soal yang kurang lebih sama seperti soal tersebut, sehingga dia dapat menjawab soal tersebut dengan lancar dan benar. Dia memperoleh soal tersebut di internet dia mengatakan bahwa di sekolah tidak pernah mendapat soal seperti itu sebelumnya. siswa yang memperoleh skor tinggi juga tergolong anak yang aktif dalam belajar di kelas maupun di rumah dia suka mencari soal-soal di internet lalu dikerjakannya sehingga dia terbiasa dengan soal-soal baru yang tidak diajarkan di sekolah. Siswa yang memperoleh skor sedang saat ditanyakan sebelumnya tidak pernah mendapat soal seperti yang peneliti berikan sehingga dia merasa sedikit bingung dalam mengerjakan soal tersebut, dia hanya dapat menyatakan 1 soal dengan benar. Saat belajar dia hanya mengerjakan soal- soal yang guru berikan saja. Sedangkan siswa yang memperoleh skor rendah saat ditanyakan sebelumnya juga tidak pernah mendapat soal seperti yang peneliti berikan sehingga dia merasakan kebingungan dalam menjawab soal seperti soal nomor 2 dia salah memahami maksud soal sehingga dia salah dalam menggambarkan soal tersebut, siswa yang memperoleh skor rendah tersebut di kelas merupakan siswa yang pasif saat proses pembelajaran bahkan dia juga tidak dapat menyatakan seseuatu ketika ditanyakan oleh guru mengenai pembelajaran ternyata hal ini biasa terjadi di rumah dia tidak pernah dimintai pendapat oleh orang rumah mengenai pembelajaran yang terjadi di sekolah. Hal ini lah yang mungkin mempengaruhi dia dalam pembelajaran.

Berpikir kritis siswa pada soal nomor 1 dan 2 pada indikator claim tergolong tinggi berdasarkan hasil rata-rata skor pada indikator claim yakni 83\%. Terdapat 16 atau 53\% siswa dapat menyatakan hasil dengan benar. Terdapat 8 atau $27 \%$ siswa kurang tepat 
Vol 1 No 22020 Desember 2020

Jurnal AlphaEuclidEdu

Received: 21/10/2020; Revised: 30/11/2020; Accepted: 06/12/2020

dalam mengclaim soal nomor 1 dan 2 sedangkan 6 atau 20\% siswa lainnya hanya mengclaim 1 soal saja dari soal nomor 1 dan 2 .

Pada indikator argumen peneliti memberikan 2 soal dengan soal yang berbeda. Berikut pembahasan dari indikator argumen.

Hasil analisis pada soal nomor 1 dan 2 pada indikator argumen ada 5 dari 30 siswa yang dapat memberikan argumen dengan benar, 6 dari 30 siswa tidak tepat dalam memberikan alasan kenapa mereka menyatakan bahwa soal nomor 1 itu benar dan soal nomor 2 itu salah, 13 dari 30 siswa hanya dapat memberikan argumen pada 1 soal saja dan 5 siswa tidak memberikan argumen kenapa mereka dapat menyatakan benar dan salah. Setelah dilakukan wawancara kepada 3 siswa yang mendapat skor tinggi, sedang dan rendah pada indikator argumen diketahui bahwa siswa yang memperoleh skor timggi sebelumnya pernah mendapatkan soal yang kurang lebih sama seperti soal yang peneliti berikan dia mangatakan bahwa dia memperoleh soal tersebut di bimbingan belajar online yang dia ikuti sehingga dia bisa mengejakan soal tersebut dengan lancar.

Siswa yang memperoleh skor sedang ketika ditanyakan sebelumnya tidak pernah mendapatkan soal seperti yang peneliti berikan begitu juga dengan siswa yang mendapat skor rendah. Siswa yang memperoleh skor sedang salah dalam memberikan beragumen mengenai jumlah sudut segitiga ABD pada soal nomor 2 dia salah dalam menjumlahkan dan mengurangkan sudut pada segtiga tersebut karena argumen yang dia berikan salah maka dia juga salah dalam menyatakan soal nomor 2 .

Sedangkan siswa yang memperoleh skor rendah pada soal nomor 1 dia memberikan argumen yang tidak tepat mengapa dia menyatakan soal nomor 1 tersebut benar dan pada soal nomor 2 dia tidak menjawab. Ternyata di dalam proses pembelajaran siswa yang memperoleh skor tinggi merupakan siswa yang sering bertanya dan aktif dalam pembelajaran seperti dapat menyampaikan pendapat ketika ditanya oleh guru ataupun temannya, dia juga mengatakan bahwa di rumah dia sering dimintai pendapat mengenai pembelajaran dia di sekolah dan mengenai pekerjan rumah adik atau sepupunya bahkan dia sering mencari soal-soal di internet lalu mengerjakannya sehingga dia terbiasa dengan soal-soal baru yang bahkan tidak diberikan di sekolah hal inilah yang membuat dia dapat menjawab soal tersebut dengan benar. Siswa yang memperoleh skor sedang dan rendah di dalam kelas tergolong siswa yang pasif karena ketika dimintai pendapat oleh guru mengenai pembelajaran dia hanya sesekali dapat memberikan jawabannya. Ternyata menurut siswa yang mendapat skor sedang dan rendah ketika di rumah pun mereka seperti itu.

Berpikir kritis siswa pada soal nomor 1 dan 2 pada indikator argumen tergolong sedang berdasarkan hasil persentase rata-rata skor yakni $68 \%$. Terdapat 11 siswa atau $37 \%$ yang dapat memberikan berargumen mengenai apa yang telah dia claim pada soal nomor 1 dan 2 dengan benar, 6 atau 20\% siswa memberikan argumen mengenai apa yang telah dia 
Vol 1 No 22020 Desember 2020

Jurnal AlphaEuclidEdu

Received: 21/10/2020; Revised: 30/11/2020; Accepted: 06/12/2020

claim pada soal nomor 1 dan 2 namun kurang tepat dan 13 atau 43\% siswa lainnya hanya memberikan argumen pada salah satu soal saja dari 2 soal yang diberikan. Hal ini sesuai dengan penelitian yang dilakukan oleh Feridia (2017) mengenai kemampuan berpikir kritis pada aspek Explanation dengan indikator menyajikan argumen tergolong sedang yaitu $41,35 \%$ dan penelitian yang dilakukan oleh Nurhakim (2019) mengenai kemampuan berpikir kritis siswa sekolah menengah atas yaitu siswa yang mempunyai kemampuan berpikir kritis matematik sedang, siswa dapat mengungkapkan atau membuat kesimpulan. Pada indikator issue peneliti menyiapkan 1 soal. Berikut pembahasan dari indikator issue.

Hasil analisis pada soal nomor 3 pada indikator issue ada 1 dari 30 siswa yang mengajukan bertanyaan paling banyak yaitu 3 pertanyaan benar, 4 dari 30 siswa mengajukan 3 pertanyaan ada pertanyaan yang benar dan ada pertanyaan yang salah, 12 dari 30 siswa mengajukan 1 pertanyaan ada pertanyaan yang benar dan ada pertanyaan yang salah, dan 13 siswa yang lainnya tidak mengajukan pertanyaan. Setelah dilakukan wawancara kepada 3 orang siswa yang mendapat skor tinggi, sedang dan rendah pada indikator issue diketahui bahwa ketiga siswa tersebut tidak pernah memperoleh soal seperti yang peneliti berikan sebelumnya, namun 17 siswa dapat mengajukan pertanyaan mengenai gambar-gambar yang ditampilkan pada soal nomor 3. Siswa yang memperoleh skor tinggi dengan mengajukan 4 pertanyaan benar, berikut salah satu pertanyaan yang ia ajukan “Apakah segitiga 1, 2, dan 3 memiliki perbandingan sudut yang sama?" ketika ditanya kenapa kamu mengajukan pertanyaan tersebut dan kira-kira apa jawaban dari pertanyaan yang kamu ajukan,dia dapat menjelaskan kenapa dia mengajukan pertanyaan tersebut dan dia juga dapat memberikan jawaban dari pertanyaan yang telah dia ajukan. Dia dapat menegajukan pertanyaan paling banyak diantara teman-temannya yang lain karena dia terbiasa bertanya dan ketika ditanya oleh guru dia dapat menjawab pertanyaan yang guru berikan mengenai pembelajaran.

Siswa memperoleh skor sedang dengan mengajukan 1 pertanyaan. Berikut pertanyaan yang ia ajukan "Apakah sudut-sudut segitiga 1, 2, dan 3 memiliki besaran yang sama?" ketika ditanya kenapa kamu mengajukan pertanyaan tersebut dan kira-kira apa jawaban dari pertanyaan yang kamu ajukan, dia tidak dapat mengatakan alasan kenapa dia mengajukan pertanyaan tersebut namun mengetahui jawaban atas pertanyaan yang dia ajukan, namun jawaban tersebut kurang tepat. Dia mengatakan bahwa ketika pembelajaran di kelas hanya sesekali bertanya karena merasa malu untuk bertanya bahkan ketika di rumah juga hanya sesekali. Sedangkan siswa yang tidak mengajukan pertanyaan, ia mengatakan tidak tahu pertanyaan apa yang harus diajukan karena dia tidak terampil dan tidak biasa bertanya, bahkan ketika pembelajaran di kelas dia tidak pernah bertanya dan ketika ditanyakan oleh guru dia tidak dapat menjawab, ternyata ketika di rumahpun dia tidak pernah bertanya, dan juga tidak pernah ditanyakan oleh orang rumah mengenai pembelajarannya di sekolah. 
Vol 1 No 22020 Desember 2020

Jurnal AlphaEuclidEdu

Received: 21/10/2020; Revised: 30/11/2020; Accepted: 06/12/2020

Berpikir kritis siswa pada soal nomor 3 dengan indikator issue tergolong rendah berdasarkan hasil persentase rata-rata skor yakni 24\%. Hanya 5 atau $16 \%$ siswa yang dapat mengajukan 3-4 pertanyaan, 12 atau 40\% siswa yang dapat mengajukan 1 pertanyaan dan 13 siswa lainnya tidak mengajukan pertanyaan. Hal ini sejalan dengan penelitian yang dilakukan oleh rizka (2018) mengenai kemampuan berpikir kritis siswa pada aspek inference dengan indikator mempertanyakan fakta dikategorikan rendah yaitu $29 \%$ dan Rasiman (2015) Mengenai Tingkat Kemampuan Berpikir Kritis, pada level kurang kritis atau (LCTA-1) memiliki karakteristik sebagai berikut: Siswa dapat dengan jelas mengidentifikasi fakta, fakta yang diketahui atau fakta yang dipertanyakan.

\section{Kesimpulan}

Berdasarkan hasil analisis data dan pembahasan di atas, dapat kesimpulan bahwa potensi berpikir kritis siswa dalam menyelesaikan masalah pada materi trigonometri di SMA Negeri 1 Sungai Ambawang tergolong sedang terlihat dari persentase rata-rata skor siswa yakni 57\%. Berikut berpikir kritis siswa dalam menyelesaikan soal trigonometri pada indikator claim, argumen, dan issue.

4.1 Berpikir kritis siswa dalam menyelesaikan masalah trigonometri pada indikator claim tergolong tinggi dilihat berdasarkan hasil rata-rata skor pada indikator claim yakni $83,3 \%$.

4.2 Berpikir kritis siswa dalam menyelesaikan masalah trigonometri pada indikator argumen

tergolong sedang dilihat berdasarkan hasil rata-rata skor pada indikator argumen yakni $68 \%$.

4.3 Berpikir kritis siswa dalam menyelesaikan masalah trigonometri pada indikator issue tergolong rendah dilihat berdasarkan hasil rata-rata skor pada indikator Issue yakni $24 \%$.

\section{Referensi}

Feridia. (2017). Kemampuan Berpikir Kritis Ditinjau Dari Aspek Explanation Dalam Penyelesaian Masalah Perbandingan Di SMP: Universitas Tanjungpura Pontianak

Fisher, A. (2008). Berpikir Kritis : Sebuah Pengantar. Jakarta: PT. Gelora Aksara Pratama. Habsari, Sri. (2005). Bimbingan \& Konseling SMA Kelas XI. Jakarta: Grasindo.

Haris, Euis dan Utari. (2017). Hard Skills dan Soft Skills. Bandung: PT. Refika Aditama.

Jablonka, Eva. (2014). Critical Thinking in Mathematics Education. London: Department of Education and Professional Studies, King's College.

Jack, Stuart dan Mary. (2012). Critical Issues in Education : Dialogues and Dialectics. Mary Rose McCarthy: Foreword by Nel Noddings.

Muchlisin. (2013). Potensi Diri. [Online]. https://www.kajianpustaka.com/2013/10/potensidiri.html|?m=1. diakses 8 November 2019. 
Vol 1 No 22020 Desember 2020

Jurnal AlphaEuclidEdu

Received: 21/10/2020; Revised: 30/11/2020; Accepted: 06/12/2020

Mudjiyanto, B. (2018). Tipe Penelitian Eksploratif Komunikasi Eksploratory Research in Communication Study. Jakarta Pusat.

Nazir, Moh. (2017). Metode Penelitian. Jakarta : Ghalia Indonesia.

Octavia, S. (2015). Kemampuan Berpikir Kritis Berdasarkan Aspek Interpretation Di Sekolah Menengah Atas: Universitas Tanjungpura Pontianak

Permendiknas, (2016). Standar Isi. Jakarta: Depdiknas.

Purwanto. (2009). Evaluasi Hasil Belajar. Yogyakarta: Pustaka Belajar.

Richard dan brooke. (2008). Critical Thinking,Ninth Edition. Chico: McGraw-Hill Higher Education, California State University.

Sukardi. (2013). Metodologi Penelitian Pendidikan: Kompetensi dan Praktisnya. Jakarta: PT Bumi aksara.

Sugiyono. (2011). Metode Penelitian Kuantitatif, Kualitatif, dan R\&D. Bandung: Alfabeta. 
Vol 1 No 22020 Desember 2020

Jurnal AlphaEuclidEdu

Received: 21/10/2020; Revised: 30/11/2020; Accepted: 06/12/2020 
Vol 1 No 22020 Desember 2020

Jurnal AlphaEuclidEdu

\title{
TINGKAT KEPUASAN MAHASISWA TERHADAP LAYANAN AKADEMIK
}

\author{
${ }^{1}$ Hamdani, ${ }^{2}$ Asep Nursangaji \\ 1,2 Pendidikan Matematika FKIP Universitas Tanjungpura Pontianak \\ Email: hamdani.mikraj@fkip.untan.ac.id
}

\begin{abstract}
Nowadays, there are several LPTK in West Kalimantan that have mathematics education courses apart from FKIP UNTAN. This is a challenge for FKIP UNTAN to become the main choice for prospective students. So, it is very important for the FKIP UNTAN mathematics education department to provide quality academic services to students so that they feel satisfied. One of the student satisfaction assessments index in academic services in the Mathematics Education Department of FKIP UNTAN is academic guidance and course implementation. This study will examine how high the level of student satisfaction with academic services in the Mathematics education Department FKIP UNTAN. Furthermore, it will be known what service items should be improved and developed in an effort to increase student satisfaction. The method used is descriptive method with a survey form involving students in 3rd, 5th, and 7th semester. The instrument used is a satisfaction questionnaire. The level of student satisfaction with academic guidance services is $2 \%$ of students are not satisfied, $6 \%$ of students are not satisfied, 30\% of students are satisfied, 32\% of students are quite satisfied, and 30\% of students are very satisfied. Then for the level of student satisfaction with the lecture process as much as $2 \%$ of students were not satisfied, $5 \%$ of students were not satisfied, $27 \%$ of students were satisfied, 36\% of students were quite satisfied, and 30\% of students were very satisfied.

Keywords: Satisfaction; Academic Services; Academic Guidance; The Lecture Process.
\end{abstract}

\section{Pendahuluan}

Perguruan Tinggi sebagai salah satu lembaga pendidikan pada dasarnya adalah organisasi jasa, yakni memberikan layanan pendidikan pada masyarakat. Sebagai organisasi jasa, Perguruan Tinggi dituntut untuk memberikan pelayanan yang terbaik kepada pelanggan, khususnya kepada mahasiswa karena akan mempengaruhi kualitas lulusan yang dihasilkan. Fakultas Keguruan dan Ilmu Pendidikan (FKIP) Untan sebagai salah satu organisasi layanan publik, tentu juga memiliki tantangan yang sama dengan FKIP/lembaga Kependidikan Perguruan Tinggi lainnya. FKIP mengalami kondisi persaingan yang sama sehingga harus memikirkan strategi peningkatan kualitas pelayanan yang memberi kepuasan kepada mahasiswanya.Sejauh ini, Prodi Pendidikan Matematika FKIP UNTAN telah berusaha semaksimal mungkin untuk memberikan layanan akademik kepada mahasiswa sebagai konsumennya. Karena pelayanan akademik yang berkualitas akan menciptakan lulusan/mahasiswa yang berkualitas sehingga mampu bersaing di era globailsasi/ era revolusi industri 4.0. Layanan akademik tersebut, seperti: perkuliahan, kurikulum, bimbngan/konsultasi akademik, praktikum, bimbingan tugas akhir, dan lainlain (Tampubolon, 2001). Salah satu indeks penilaian kepuasan mahasiswa dalam layanan akademik di Prodi Pendidikan Matematika FKIP Untan adalah bimbingan akademik dan pelaksanaan perkuliahan.Dalam kehidupan perkuliahan, setiap mahasiswa pasti diberikan dosen pembimbing akademik yang berfungsi sebagai penunjuk arah dan advisor 
Vol 1 No 22020 Desember 2020

Jurnal AlphaEuclidEdu

mahasiswa dalam mengambil mata kuliah pada tiap semester berjalan. Setelah mendapat arahan dan petunjuk tentang mata kuliah yang akan diambil, tentunya mahasiswa akan menjalani proses perkuliahan pada tiap mata kuliah. Dari kedua indeks tersebut tentunya harus diperhatikan aspek kemudahan dan kenyamanan interaksi antara mahasiswa sebagai pelanggan dan dosen sebagai penyedia layanan.

\section{Metode Penelitian}

\section{Pendekatan Penelitian}

Penelitian ini menggunakan Pendekatan kuantitatif dengan metode deskriptif. penggunaan metode deskriptif bertujuan untuk menggambarkan secara jelas tentang kepuasan mahasiswa terhadap kualitas layanan akademik pada prodi pendidikaan matematika FKIP Untan tahun akademik 2019/2020.

Bentuk penelitian yang digunakan adalah survey studies

Waktu dan Tempat Penelitian

Penelitian ini berlokasi di Prodi Pendidikan Matematika FKIP UNTAN, yang dilakukan pada bulan Mei - Oktober 2020

\section{Populasi dan Sampel}

Populasi dalam penelitian ini adalah mahasiswa Prodi Pendidikan Matematika FKIP Untan semester 3, 5, dan 7 untuk data kepuasan layanan bimbingan akademik dan perkuliahan. Pembatasan tersebut dimaksudkan untuk menjaring mahasiswa yang telah benar-benar merasakan pelayanan pendidikan, sehingga mereka bisa menilai tingkat kepuasan serta tingkat urgensi dari pelayanan tersebut.

Untuk pengambilan sampel survei, peneliti menggunakan probability sampling, yaitu teknik pengambilan sampel yang memberikan peluang yang sama bagi setiap unsur (anggota) populasi untuk dipilih menjadi anggota sampel, dan teknik yang dipilih adalah proportionate random sampling, yaitu pengambilan anggota sampel dilakukan dengan memperhatikan proporsi yang ada dalam populasi itu.

\section{Analisis Data}

Analisis data menggunakan analisis deskriptif dengan mencari rata-rata tingkat kepuasan mahasiswa untuk masing-masing dimensi dan secara umum kemudian dibuat interval. Rentang tersebut akan digunakan sebagai dasar kriteria tingkat kepuasan mahasiswa.

\section{Hasil dan Pembahasan}

\section{Tingkat Kepuasan Mahasiswa Terhadap layanan Bimbingan Akademik}

Kepuasan mahasiswa terhadap layanan bimbingan akademik diukur dengan 13 pernyataan dengan 5 tingkat kepuasan. 5 tingkat kepuasan yang digunakan adalah tidak puas, kurang puas, puas, cukup puas, dan sangat puas. Berdasarkan hasil analisis data kuisioner yang diisi oleh 150 mahasiswa sebagai responden, didapatkan data tingkat 
Vol 1 No 22020 Desember 2020

Jurnal AlphaEuclidEdu

kepuasan mahasiswa terhadap layanan bimbingan akademik yang ditunjukan dalam gambar 1 . 
Vol 1 No 22020 Desember 2020

Jurnal AlphaEuclidEdu

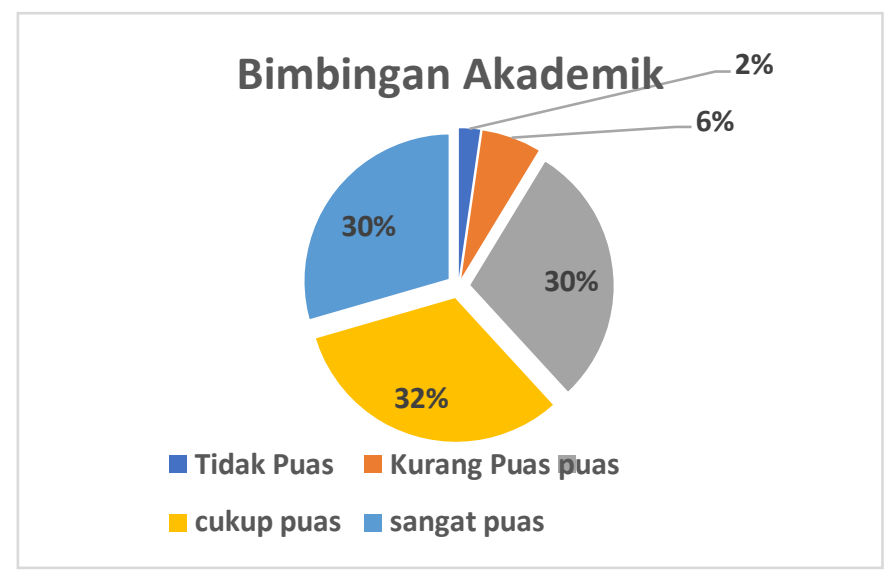

Gambar 1. Diagram tingkat kepuasan

mahasiswa terhadap layanan bimbingan

akademik.

Berdasarkan diagram di atas, dari 150 mahasiswa, sebanyak 3 mahasiswa merasa tidak puas, 9 mahasiswa merasa kurang puas, 45 mahasiswa merasa puas, 48 mahasiswa merasa cukup puas, dan 45 mahasiswa merasa sangat puas dengan layanan bimbingan akademik yang diberikan oleh para dosen yang bertupoksi sebagai dosen pembimbing akademik mahasiswa Program Studi Pendidikan Matematika Fakultas Keguruan dan Ilmu Pendidikan Universitas Tanjungpura.

Berdasarkan analisis data kuisioner yang dilakukan dengan menghitung sebaran skor di setiap distribusi frekuensi kemudian diinterpretasikan dengan kriteria persentase, dari 150 mahasiswa, sebanyak 2\% mahasiswa merasa tidak puas, 6\% mahasiswa merasa kurang puas, $30 \%$ mahasiswa merasa puas, 32\% mahasiswa merasa cukup puas, dan $30 \%$ mahasiswa merasa sangat puas dengan layanan bimbingan akademik yang diberikan oleh para dosen yang bertupoksi sebagai dosen pembimbing akademik mahasiswa Program Studi Pendidikan Matematika Fakultas Keguruan dan Ilmu Pendidikan Universitas Tanjungpura.

Secara umum semua indikator kepuasan dinilai sudah memuaskan dengan hasil kepuasan $92 \%$. Artinya pelayanan bimbingan akademik yang diberikan oleh para dosen yang bertupoksi sebagai dosen pembimbing akademik mahasiswa Program Studi Pendidikan Matematika Fakultas Keguruan dan Ilmu Pendidikan Universitas Tanjungpura sudah cukup baik. Hal ini menunjukkan bahwa para dosen pembimbing akademik masingmasing mahasiswa sudah berusaha sangat cukup optimal dalam menjalankan tugas pokok dan fungsinya sebagai pembimbing. Aspek - aspek yang membuat mahasiswa puas dengan layanan bimbingan akademik oleh dosen pembimbing akademik adalah ketersedian waktu 
Vol 1 No 22020 Desember 2020

Jurnal AlphaEuclidEdu

dan kemudahan untuk ditemui oleh para mahasiswa bimbingan ( Availability ). Pemahaman tentang layanan akademik dan administrasi akademik ( Understanding). Penguasaan sarana dan prasarana bimbingan akademik berupa SIAKAD UNTAN (Ability). Dan memberikan panduan serta solusi pada masalah yang dihadapi oleh para mahasiswa bimbingan.( Guiding and Problem Solving). Aspek - aspek tersebut merupakan hal yang penting untuk mewujudkan layanan bimbingan akademik yang prima, sesuai pendapat Parasuraman (Noermanjati,2010) yang menyatakan bahwa hal-hal yang dinginkan mahasiswa kepada dosen sebagai unit layanan akademik yaitu mengenai ketersediaan, keramahan, pemahaman dan interaksi dosen pembimbing akademik dengan mahasiswa bimbingannya.

Berdasarkan data di atas juga, Hasil kepuasan masih menunjukkan adanya kecenderungan ketidakpuasan aspek sebesar 8\%. Masih terdapat beberapa persen mahasiswa Program Studi Pendidikan Matematika Fakultas Keguruan dan Ilmu Pendidikan Universitas Tanjungpura yang merasa kurang puas bahkan tidak puas dengan layanan bimbingan akademik yang telah diberikan oleh dosen pembimbing akademik. Setelah dilakukan penelusuran lanjutan, hal yang membuat beberapa persen mahasiswa kurang puas bahkan tidak puas adalah ketidakakraban mahasiswa tersebut dengan DPAnya , kemudian juga ada yang tidak mendapatkan arahan atau gambaran mengenai masa depan mereka setelah lulus dari Program Studi Pendidikan Matematika Fakultas Keguruan dan Ilmu Pendidikan Universitas Tanjungpura. factor - factor yang menyebabkan hal tersebut yaitu kurangnya intensitas pertemuan mahasiswa tersebut dengan dosen pembimbing akademiknya, pertemuan hanya dilakukan sekali tiap semester dengan agenda laporan atau ada arahan mata kuliah atau bahkan hanya sekedar meminta tanda tangan LIRS saja. Factor lainnya adalah karakteristik mahasiswa yang tidak homogen, ada yang aktif, ada juga yang pasif.

Maka dari itu, hal - hal yang dapat dilakukan untuk meningkatkan kepuasan mahasiswa secara menyeluruh adalah dengan memperbanyak intensitas agenda bimbingan akademik. Baik itu agenda arahan mata kuliah hingga agenda controlling atau conseling. Kemudian dapat dilakukan kegiatan pembekalan karir bagi mahasiswa yang akan memasuki tahap akhir dari perkuliahan S1 Program Studi Pendidikan Matematika Fakultas Keguruan dan Ilmu Pendidikan Universitas Tanjungpura. Sehingga ada gambaran, arahan dan tujuan bagi para mahasiswa. Hal itu juga dapat meningkatkan motivasi untuk menyelesaikan proses tugas akhir mereka masing- masing.

Tingkat Kepuasan Mahasiswa Terhadap Layanan Proses Perkuliahan

Kepuasan mahasiswa terhadap layanan proses perkuliahan diukur dengan 15 pernyataan dengan 5 tingkat kepuasan. 5 tingkat kepuasan yang digunakan adalah tidak puas, kurang puas, puas, cukup puas, dan sangat puas. Berdasarkan hasil analisis data kuisioner yang diisi oleh 150 mahasiswa sebagai responden, didapatkan data tingkat 
Vol 1 No 22020 Desember 2020

Jurnal AlphaEuclidEdu

kepuasan mahasiswa terhadap layanan proses perkuliahan yang ditunjukkan di dalam gambar 2.

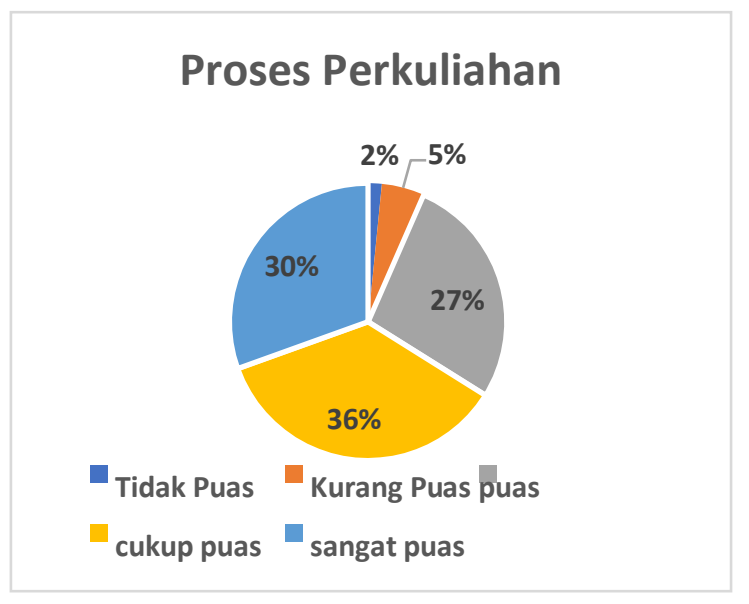

Gambar 2. Diagram tingkat kepuasan mahasiswa terhadap layanan proses perkuliahan.

Berdasarkan diagram di atas, dari 150 mahasiswa, sebanyak 3 mahasiswa merasa tidak puas, 8 mahasiswa merasa kurang puas, 41 mahasiswa merasa puas, 54 mahasiswa merasa cukup puas, dan 45 mahasiswa merasa sangat puas dengan layanan proses perkuliahan yang diberikan oleh para dosen yang bertupoksi sebagai dosen pengampu mata kuliah di Program Studi Pendidikan Matematika Fakultas Keguruan dan Ilmu Pendidikan Universitas Tanjungpura.

Berdasarkan analisis data kuisioner yang dilakukan dengan menghitung sebaran skor di setiap distribusi frekuensi kemudian diinterpretasikan dengan kriteria persentase, dari 150 mahasiswa, sebanyak $2 \%$ mahasiswa merasa tidak puas, $5 \%$ mahasiswa merasa kurang puas, $27 \%$ mahasiswa merasa puas, 36\% mahasiswa merasa cukup puas, dan 30\% mahasiswa merasa sangat puas dengan layanan proses perkuliahan yang diberikan oleh para dosen yang bertupoksi sebagai dosen pengampu mata kuliah Program Studi Pendidikan Matematika Fakultas Keguruan dan Ilmu Pendidikan Universitas Tanjungpura.

Secara umum semua indikator kepuasan dinilai sudah memuaskan dengan hasil kepuasan 93\%. Artinya pelayanan proses perkuliahan yang diberikan oleh para dosen yang bertupoksi sebagai dosen pengampu mata kuliah Program Studi Pendidikan Matematika Fakultas Keguruan dan Ilmu Pendidikan Universitas Tanjungpura sudah cukup baik. Hal ini menunjukkan bahwa para dosen pengampu mata kuliah sudah berusaha sangat cukup optimal dalam menjalankan tugas pokok dan fungsinya sebagai pengampu Aspek - aspek yang membuat mahasiswa puas dengan layanan proses perkuliahan oleh dosen pengampu mata kuliah adalah ketepatan waktu memulai dan mengakhiri perkuliahan ( Time Management ). Penguasaan materi mata kuliah yang diampu (Mastering ). Melakukan proses konfirmasi dan klarifikasi kepada mahasiswa pada materi dalam mata kuliah yang 
Vol 1 No 22020 Desember 2020

Jurnal AlphaEuclidEdu

diampu, memastikan kelas mahasiswa mengerti sebelum lanjut ke materi berikutnya.

Berdasarkan data di atas juga, Hasil kepuasan masih menunjukkan adanya kecenderungan ketidakpuasan aspek sebesar 7\%. Masih terdapat beberapa persen mahasiswa Program Studi Pendidikan Matematika Fakultas Keguruan dan Ilmu Pendidikan Universitas Tanjungpura yang merasa kurang puas bahkan tidak puas dengan layanan proses perkuliahan yang telah diberikan oleh dosen pengampu mata kuliah. Setelah dilakukan penelusuran lanjutan, hal yang membuat beberapa persen mahasiswa kurang puas bahkan tidak puas adalah ketidakpahaman mahasiswa terhadap penyampaian dosen pengampu mata kuliah, kemudian juga ada yang merasa bosan dengan gaya penyampaian dosen pengampu mata kuliah yang cenderung tidak menarik dan monoton. Dan yang terakhir adalah proses evaluasi dosen pengampu mata kuliah yang berujung dengan beragamnya nilai akhir mata kuliah yang diampu. factor - factor yang menyebabkan hal tersebut yaitu karakteristik mahasiswa yang tidak homogen, ada yang aktif, ada juga yang pasif., ada yang rajin, pasti ada juga yang kurang rajin, dan perbedaan daya tangkap yang dimiliki oleh kelas mahasiswa. Factor lainnya adalah dosen pengampu kurang mengamati kondisi kelas dan kurang memanfaatkan fasilitas untuk membuat suasana pembelajaran menjadi efektif secara menyeluruh.

Maka dari itu, hal - hal yang dapat dilakukan untuk meningkatkan kepuasan mahasiswa secara menyeluruh adalah dengan mengkondisikan kelas dan memetakan kemampuan kelas mahasiswa sehingga dapat dilakukan tindak lanjut untuk mencapai pemahaman kelas yang merata. Selanjutnya adalah dosen pengampu mata kuliah harus sudah memulai memanfaatkan berbagai jenis teknologi dan fasilitas yang dapat membangkitkan focus dan keefektifan proses perkuliahan mata kuliah tersebut.

\section{Kesimpulan dan Saran}

\section{Kesimpulan}

Tingkat kepuasan mahasiswa terhadap layanan bimbingan akademik adalah 2\% mahasiswa merasa tidak puas, 6\% mahasiswa merasa kurang puas, 30\% mahasiswa merasa puas, 32\% mahasiswa merasa cukup puas, dan 30\% mahasiswa merasa sangat puas. Kemudian untuk tingkat kepuasan mahasiswa terhadap proses perkuliahan adalah sebanyak $2 \%$ mahasiswa merasa tidak puas, 5\% mahasiswa merasa kurang puas, 27\% mahasiswa merasa puas, $36 \%$ mahasiswa merasa cukup puas, dan $30 \%$ mahasiswa merasa sangat puas

Hal- hal yang harus diperbaiki untuk meningkatkan kepuasan mahasiswa terhadap layanan akademik secara menyeluruh adalah dengan memperbanyak intensitas agenda bimbingan akademik. kemudian melakukan kegiatan pembekalan karir bagi mahasiswa yang akan memasuki tahap akhir dari perkuliahan, mengkondisikan kelas dan memetakan kemampuan kelas mahasiswa sehingga dapat dilakukan tindak lanjut untuk mencapai pemahaman kelas yang merata, dan memulai memanfaatkan berbagai jenis teknologi dan fasilitas yang dapat membangkitkan focus dan keefektifan proses perkuliahan mata kuliah tersebut. 
Vol 1 No 22020 Desember 2020

Jurnal AlphaEuclidEdu

\section{Saran}

Perlu dilakukan tindak lanjut dari hasil penelitian ini sehingga dapat meningkatkan mutu layanan dan mutu sumber daya manusa di Program Studi Pendidikan Matematika Fakultas Keguruan dan Ilmu Pendidikan Universitas Tanjungpura.

\section{Referensi}

Buchari Alma. 2009. Pemasaran Jasa Pendidikan yang Fokus Pada Mutu, dalam Buchari Alma dan Ratih Hurriyati (ed.), ManajemenCorporate \& Strategi Pemasaran Jasa Pendidikan. Bandung: Alfabeta.

Elliot, K..; Shin, D. 1999. Assessing student satisfaction: an approach to help in the development of marketing strategy for a university. Marketing Management Association.

Jurkowitsch, Silke, et.al. 2006, A Student Satisfaction Model For Austrian Higher Education Providers Considering Aspects Of Marketing Communications, Special Edition On Consumer Satisfaction - Global Perspective, pp. 9-23

Kotler, Philip. 1997. Manajemen Pemasaran, Analisis, Perencanaan, Implementasi dan Control Jilid I. Edisi-9 Jakarta: PT Prenhallindo

Mahmud, Marzuki. 2012. Manajemen Mutu Perguruan Tinggi. Jakarta: Rajawali Press. Supranto, J.2006. Pengukuran Tingkat Kepuasan Pelanggan. Jakarta: Rieneka Cipta Tampubolon, Daulat P. 2001. Perguruan Tinggi Bermutu. Jakarta: PT. Gramedia Pustaka Utama Tjiptono, Fandy. 1997. Strategi Pemasaran. Yogyakarta: Andi Offset.

Yamif, Zuliam. 2001. Manajemen Kualitas Produk. Yogyakarta: Ekonisia

Zeithaml, V.A. dan Bitner, M.J. 2000. Services Marketing: Integrating Customer Focus Across the Firm. (United States of America: Irwin McGraw-Hill 
Vol 1 No 22020 Desember 2020

Jurnal AlphaEuclidEdu

Received: 21/10/2020; Revised: 30/11/2020; Accepted: 08/12/2020

\title{
PENGEMBANGAN BAHAN AJAR INTERAKTIF UNTUK PEROLEHAN KETERAMPILAN PADA MATERI LINGKARAN
}

\author{
${ }^{1}$ Ulya, Ulvi, ${ }^{2}$ Suratman, Dede, ${ }^{3}$ Nursangaji, Asep \\ 1,2,3 Pendidikan Matematika FKIP Universitas Tanjungpura Pontianak \\ Email: uulya.96@gmail.com
}

\begin{abstract}
This research aims to determine the feasibility of interactive teaching materials that are developed, and how intellectual skills of students after using teaching materials that are developed. The research method used is descriptive. The subjects of this research were 24 students from class XI SMP Islam Bawari Pontianak. The data source of this research were the student test answers sheet, and the validation sheet for the feasibility of interactive teaching materials. The results showed that interactive teaching materials were declared to be very valid, refer to material experts and media experts. The students' intellectual skills of relationship the central angle with length of arc is $58.33 \%$ in the sufficient category. The students' intellectual skills of relationship the central angle with area of circle sector is $50 \%$ in the sufficient category. The students' intellectual skills of solve problems related to the central angle, inscribed angle, length of arc, and area of circle sector, and its relationship is $20.83 \%$ in the low category.
\end{abstract}

Keywords: Circles, Intellectual Skills, Interactive Teaching Materials

\section{Pendahuluan}

Materi pembelajaran ialah satu diantara muatan pembelajaran yang diperlukan dalam proses belajar mengajar supaya tujuan pembelajaran bisa tercapai. Nana dan Ibrahim mengungkapkan bahwa materi pembelajaran adalah suatu yang disuguhkan guru untuk ia proses dan selanjutnya dipahami oleh siswa, untuk mencapai tujuantujuan instruksional yang sudah ditentukan (dalam Abi, 2012). Depdiknas (2006:4) mengatakan bahwa bahan ajar maupun materi pembelajaran pada umumnya berisi pengetahuan, keterampilan, dan sikap yang wajib dipelajari siswa untuk memenuhi standar kompetensi yang ada. Dari pendapat tersebut, peneliti menyarikan bahan ajar yakni seperangkat materi pelajaran yang bisa menolong terpenuhinya tujuan kurikulum yang dibuat secara terurut dan lengkap agar menciptakan suasana belajar yang mengasyikkan, mempermudah siswa belajar, dan guru mengajar.

Sementara itu, Prastowo menyatakan bahwa fakta dilapangan, terdapat guru yang masih menerapkan bahan ajar konvesional, berupa bahan ajar yang siap digunakan, serta tanpa proses perencanaan (Prastowo, 2011). Oleh karena itu, resiko sangat memungkinkan apabila bahan ajar yang digunakan belum konstekstual, kurang menarik, menoton, serta belum sesuai dengan kebutuhan siswa. Hal ini dialami peneliti saat menjalankan Praktik Pengalaman Lapangan (PPL) di SMP Islam Bawari Pontianak. Bahwa dalam proses pembelajaran khususnya matematika, guru masih menerapkan bahan ajar konvensional berupa Buku Sekolah Elektronik (BSE).

Menurut peneliti, buku tersebut masih kurang memadai kebutuhan siswa, hal ini ditunjukkan dari keluhan siswa yang kurang memahami materi dalam buku tersebut, terutama pada pilihan kata yang digunakannya. 
Vol 1 No 22020 Desember 2020

Jurnal AlphaEuclidEdu

Sehingga siswa mengalami kesulitan untuk menyelesaikan soal matematika, terutama soal bagian keterampilan. Peneliti juga mewawancarai guru matematika di sekolah, beliau menyatakan saat proses pembelajaran berlangsung, terutama pada materi lingkaran, banyak siswa yang kurang fokus, tidak memperhatikan serta ada yang berbicara. Ini mengakibatkan siswa susah mengerti materi yang diajarkan guru, terutama saat menentukan sudut pusat,panjang busur, dan luas juring lingkaran, sehingga hasil belajarnya belum memuaskan. Bahan ajar yang digunakan guru tersebut kurang memadai.

Terdapat hal yang menarik ketika peneliti mengajar di sana. Peneliti membuat sebuah media pembelajaran, yaitu power point. Saat mengajar dengan media tersebut, siswa banyak yang memperhatikan bahkan semuanya ikut berkontribusi dalam materi yang disampaikan. Dan siswa cenderung memahami materi yang telah disampaikan oleh peneliti. Sehingga siswa bisa mengerjakan soal matematika, terutama bagian keterampilan. Oleh karena itu, peneliti berpendapat bahwa bahan ajar yang digunakan guru saat ini kurang memadai. Oleh karena itu, peneliti tertarik mengembangkan sebuah bahan ajar untuk menunjang kegiatan belajar dan pembelajaran.

Banyak teknologi yang telah berkembang pada zaman ini. Untuk membuat media pembelajaran pun tidak hanya dengan power point. Contoh teknologi yang dapat menunjang belajar siswa adalah 3D PageFlip. 3D PageFlip ini adalah sebuah aplikasi berupa buku elektronik, dengan tampilan berupa buku secara nyata. Namun bisa ditambahkan dengan audio, video, dan lainnya. Program 3D PageFlip mudah digunakan, fitur-fiturnya sederhana, namun hasilnya memuaskan.

Prastowo mengungkapkan bahwa bahan ajar terbagi dari bentuk, cara kerja, dan sifat. Dari bentuknya, terbagi menjadi 4 macam yakni: (1) bahan cetak (printed); (2) bahan ajar dengar atau program audio; (3) bahan ajar pandang dengar (audiovisual); (4) bahan ajar interaktif (Prastowo, 2012). Bahan ajar yang ingin peneliti kembangkan ialah bahan ajar interaktif. Prastowo menyatakan bahwa bahan ajar interaktif bisa dikelompokkan menjadi dua, yaitu Compact Disk (CD) interaktif dan orang (Prastowo, 2012). Dalam penelitian ini peneliti memilih menciptakan bahan ajar interaktif dalam bentuk CD interaktif. Sehingga bahan ajar yang dikembangkan akan dimuat dalam sebuah $\mathrm{CD}$, agar mudah digunakan.

Sehingga peneliti ingin mengembangkan sebuah bahan ajar interaktif dengan menggunakan program 3D Pageflip, dan dimuat dalam sebuah CD. Materi yang dipilih ialah lingkaran, dengan submateri sudut pusat, panjang busur, dan luas juring lingkaran. Bahan ajar interaktif yang sudah dikembangkan, akan dilihat kelayakannya dan bagaimana keterampilan intelektual siswa sebelum dan sesudah menerapkan bahan ajar. Karena penelitian ini berupa pengembangan, peneliti berpatokan dengan prosedur penelitian pengembangan Sugiyono. Sugiyono menyatakan bahwa terdapat 10 tahapan dalam penelitian pengembangan, yaitu: (1) Potensi dan Masalah; (2) Pengumpulan Data; (3) Desain Produk; (4) Validasi Desain; (5) Revisi Desain; (6) Ujicoba Produk; (7) Revisi Produk; (8) Ujicoba Penggunaan; (9) Perbaikan Produk; (10) Pembuatan 
Vol 1 No 22020 Desember 2020

Jurnal AlphaEuclidEdu

Produk Masal (Sugiyono, 2017). Namun, pada penelitian ini, peneliti hanya melewati tahap 1 hingga 7 . Berikut penjelasannya.

\section{Potensi dan Masalah}

Adanya masalah atau potensi dapat dijadikan landasan suatu penelitian. Potensi ialah ragam hal yang jika diberdayagunakan akan mempunyai nilai lebih. Contohnya, di pantai selatan pulau jawa, ada potensi sinar matahari dan angin, yang keduanya bisa ditingkatkan menjadi energi mekanik yang bisa dipakai dalam memobilisasi sesuatu.

\section{Pengumpulan Data}

Selepas potensi dan masalah bisa ditampilkan secara objektif dan terkini, kemudian harus dihimpun beragam informasi yang bisa dipakai menjadi bekal dalam perancangan produk yang diinginkan bisa menangani masalah itu.

\section{Desain Produk}

Sesudah melakukan pengumpulan data, dilanjutkan dengan desain produk. Desain produk yang dibuat peneliti harus lengkap dengan spesifikasinya, dan ditampilkan dalam gambar atau bagan, agar bisa dipakai semacam patokan dalam menilai dan membuatnya.

\section{Validasi Desain}

Validasi desain ialah proses untuk mengetahui kefektifan rancangan produk yang dibuat. Validasi ini tetap berupa penilaian dari pendapat logis, tanpa kenyataan lapangan. Validasi produk bisa dilakukan dengan menemui spesialis yang telah berpengalaman dalam mengukur produk baru yang dibuat.

\section{Revisi Desain}

Sesudah desain produk dan validasi desain terlewati, lalu dapat diketahui kekurangannya. Selanjutnya kekurangan itu dikurangi dengan cara menyunting desain.

\section{Ujicoba Produk}

Dalam dunia pendidikan, desain produk bisa lantas diuji coba, sesudah divalidasi dan diperbaiki. Uji coba fase awal dilaksanakan berupa simulasi. Sehabis disimulasikan, maka boleh diujicobakan dalam kelompok terbatas. Tujuan uji coba dilakukan agar memperoleh informasi apakah aplikasi yang dibuat berdaya guna baik.

\section{Revisi Produk}

Revisi produk dilakukan jika salah satu hal yang diujikan belum memenuhi target yang diinginkan. Sehingga produk direvisi kembali. Jika pengujicobaan awal berhasil lebih efektif dan efisien, maka peneliti bisa menerapkannya di ruang lingkup yang lebih luas tempat sampel diambil.

Guidelines for Bibliographic Description of Interaktive Multimedia menyatakan bahwa Bahan ajar interaktif merupakan gabungan dari dua atau lebih media (audio, teks, grafik, gambar, dan video) oleh penggunanya dimanipulasi untuk mengontrol perintah dan atau perbuatan alami dari suatu presentasi (dalam Prastowo, 2012). Program yang digunakan peneliti yaitu 3D Pageflip, yang juga bisa mengkombinasikan dua atau lebih media. Peneliti mengkombinasikan audio, teks, dan gambar dalam bahan ajar interaktif. Kemudian Munir menyatakan karakteristik dari media pembelajaran multimedia 
Vol 1 No 22020 Desember 2020

Jurnal AlphaEuclidEdu

interaktif adalah: (1)Memiliki lebih dari satu media yang konvergen, misalnya menggabungkan unsur audio dan visual; (2) Bersifat interaktif, memiliki kemampuan mengakomodasi respons pengguna; (3) Bersifat mandiri, memberi kemudahan dan kelengkapan isi sehingga pengguna bisa menggunakan tanpa bimbingan orang lain (Munir, 2012). Untuk kelayakan bahan ajar interaktif yang dikembangkan, peneliti mengacu pada BSNP (Badan Standar Nasional Pendidikan) sebagai kelayakan materi dan pembelajaran, serta Yudhi Munadi sebagai kelayakan media. BSNP (Badan Standar Nasional Pendidikan) mengungkapkan bahwa ada 4 komponen yang dinilai untuk menentukan kelayakan bahan ajar yaitu: (1) kelayakan isi; (2) kelayakan bahasa; (3) kelayakan penyajian; (4) kelayakan kegrafikkan (BSNP, 2007). Namun peneliti hanya menggunakan 3 komponen, berikut penjelasannya.

\section{Kelayakan isi}

Muatan kelayakan isi ini dipecah dalam indikator yakni: (1) alignment dari SK dan KD mata pelajaran, pertumbuhan anak, kebutuhan masyarakat; (2) esensi keilmuan dan keterampilan; (3) pikiran untuk maju dan berkembang; dan (4) perbedaan nilai-nilai sosial.

\section{Kelayakan bahasa}

Komponen kebahasaan ini disajikan menjadi tiga indikator ialah: (1) keterbacaan; (2) analogi dengan kaidah Bahasa Indonesia yang baik dan benar; dan (3) logika berbahasa.

\section{Kelayakan penyajian}

Muatan penyajian ini dipecah menjadi tiga indikator yakni: (1) teknik; (2) materi; dan (3) pembelajaran.

Yudhi Munadi memaparkan bahwa saat mendesain dan membuat bahan ajar interaktif berbasis komputer, harus memerhatikan lima poin berikut sebagai kriteria dalam menilai bahan ajar interaktif, yakni: (1) Kriteria kemudahan navigasi. Suatu program baiknya didesain sesimpel mungkin agar siswa tak harus mengerti komputer lebih dulu; (2) Kriteria kandungan kognisi. Muatan isi program mengasih kemahiran kognitif yang diperlukan siswa; (3) Kriteria integrasi media, artinya media patut memadukan aspek-aspek dan keterampilan lain yang wajib dipelajari. Pembelajaran integrative memfokuskan pada penggabungan beberapa keterampilan berbahasa, mendengarkan, berbicara, menulis, dan membaca; (4) Untuk memunculkan minat siswa aplikasi harus memiliki tampilan yang kreatif, sehingga estetika juga menjadi kriteria; (5) Kriteria penilaian akhir berupa manfaat secara total. Aplikasi yang diciptakan baiknya menyajikan pembelajaran yang dibutuhkan siswa secara penuh. Sehingga saat siswa selesai menggunakan aplikasi itu, ia akan merasa telah belajar sesuatu (Munadi, 2008).

Untuk keterampilan, peneliti mengacu pada Wina Sanjaya. Wina Sanjaya menyatakan bahwa keterampilan ialah kegiatan yang mempunyai maksud tertentu yang membutuhkan manipulasi dan penyelarasan informasi. Keterampilan terbagi menjadi dua, yaitu keterampilan intelektual dan keterampilan fisik. Keterampilan intelektual adalah keterampilan berfikir dengan usaha menggali, mengatur, dan menerapkan 
Vol 1 No 22020 Desember 2020

Jurnal AlphaEuclidEdu

berbagai informasi, berupa data, fakta, konsep, prinsip, maupun teori. Misalnya, keterampilan pemecahan masalah, dengan langkah-langkah yang sistematis, keterampilan mengevaluasi suatu program atau objek, keterampilan mengatur program kegiatan, dan keterampilan menciptakan perencanaan. Keterampilan fisik ialah keterampilan motoric berupa keterampilan menggunakan komputer, keterampilan mengemudi, keterampilan menggambar/melukis, atau memperbaiki suatu alat (Sanjaya, 2013).

Dalam penelitian ini, peneliti menggunakan keterampilan intelektual. Peserta didik dikatakan memiliki keterampilan intelektual jika mampu menerapkan konsep, prinsip maupun teori dalam menentukan luas juring dan panjang busur lingkaran. Untuk materi, peneliti memilih materi lingkaran dengan submateri sudut pusat, panjang busur, dan luas juring lingkaran.

\section{Metode Penelitian}

Dalam penelitian dan pengembangan ini, untuk prosedur pengembangan peneliti mengadopsi teori dari Sugiyono. Berikut penjelasannya.

\section{Potensi dan Masalah}

\section{Potensi}

Dikarenakan penelitian ini ialah pengembangan bahan ajar interaktif, sehingga salah satu alat yang perlu digunakan untuk menerapkan bahan ajar interaktif ini adalah infocus dan laptop. Beberapa sekolah di Pontianak sudah mulai menambahkan fasilitas seperti infocus, laptop / komputer, dll. Sehingga besar potensi peneliti untuk melakukan penelitian disalah satu sekolah di Pontianak.

\section{Masalah}

Matematika seringkali dicap sulit oleh siswa, termasuk bagian sudut pusat, panjang busur, dan luas juring lingkaran, karena siswa sulit mengerjakan soalnya. Oleh karena itu peneliti mengambil materi ini untuk diteliti. Dan guru hanya menggunakan bahan ajar konvensional, tidak membuat bahan ajar sendiri yang menggunakan media. Agar kegiatan belajar dan pembelajaran tidak monoton. Sehingga peneliti melakukan pengembangan bahan ajar interaktif dari materi lingkaran.

\section{Pengumpulan Data}

\section{Pemilihan Sekolah}

Sekolah yang dipilih peneliti ialah SMP Islam Bawari Pontianak. SMP Islam Bawari adalah sekolah yang memakai kurikulum 2013. Sekolah dengan jumlah peserta didik yang cukup, juga memiliki masalah diketerampilan peserta didik berdasarkan dari hasil wawancara dan hasil pengambilan nilai oleh peneliti ketika PPL disana.

\section{Pemilihan materi}

Berdasarkan hasil wawancara dan hasil pengambilan nilai, peserta didik masih belum terampil dalam menyelesaikan masalah yang berkaitan dengan lingkaran.

\section{Analisis Kebutuhan}


Vol 1 No 22020 Desember 2020

Jurnal AlphaEuclidEdu

Peneliti mewawancarai salah seorang guru matematika disekolah tersebut. Hasil pengamatan peneliti ditemukan bahwa banyak siswa yang tidak bisa mengerjakan sebuah persoalan mengenai materi ini. Faktanya terlihat ketika peneliti memberikan pre test kepada peserta didik. Guru juga hanya menggunakan bahan ajar konvensional, yang menurut peneliti kurang memadai. Sehingga siswa banyak yang kurang memahami materi yang disampaikan, terutama pada materi lingkaran. Namun berdasarkan pengalaman peneliti selama melaksanakan PPL disekolah ini, siswa cepat memahami serta fokus pada pelajaran saat peneliti mengajar dengan menggunakan perangkat seperti laptop dan infocus. Siswa merasa tertarik, hal ini jarang dilakukan oleh guru disana.

\section{Desain Produk}

Peneliti membuat rancangan bahan ajar interaktif sesuai indikator pencapaian materi. Kemudian dilanjutkan dengan pembuatan naskah, pembuatan tombol, penambahan audio, penambahan animasi, dan lainnya. Rancangan bahan ajar interaktif sesuai indikator pencapaian materi bisa dilihat dari tabel 1 .

Tabel 1. Rancangan Bahan Ajar Interaktif Sesuai Indikator Pencapaian Materi

\begin{tabular}{|c|c|c|}
\hline No. & Indikator & Interaktif di dalam Bahan Ajar \\
\hline 1. & $\begin{array}{l}\text { Siswa dapat } \\
\text { menunjukkan } \\
\text { hubungan sudut } \\
\text { pusat dengan } \\
\text { panjang busur } \\
\text { lingkaran. }\end{array}$ & $\begin{array}{l}\text { a. Animasi gambar lingkaran yang ada sudut pusatnya, serta } \\
\text { beberapa pertanyaan untuk mengawali materi hubungan sudut } \\
\text { pusat dengan panjang busur lingkaran } \\
\text { b. Gambar tabel yang berisi hubungan antara sudut pusat dengan } \\
\text { panjang busur lingkaran, agar siswa tau apa hubungannya. } \\
\text { c. Tombol rumus yang merupakan akhir dari melakukan kegiatan } \\
\text { dari gambar tabel sebelumnya, agar siswa mengetahui rumusnya. } \\
\text { d. Terdapat contoh soal, serta sebuah tombol yang berisi jawaban } \\
\text { dari contoh soal tersebut }\end{array}$ \\
\hline 2. & $\begin{array}{l}\text { Siswa dapat } \\
\text { menunjukkan } \\
\text { kaitan sudut } \\
\text { pusat dengan } \\
\text { luas juring } \\
\text { lingkaran. }\end{array}$ & $\begin{array}{l}\text { a. Gambar tabel yang berisi kaitan antara sudut pusat dengan } \\
\text { panjang busur lingkaran, agar siswa tau apa hubungannya. } \\
\text { b. Tombol rumus yang merupakan akhir dari melakukan kegiatan } \\
\text { dari gambar tabel sebelumnya, agar siswa mengetahui } \\
\text { rumusnya. } \\
\text { c. Terdapat contoh soal, serta sebuah tombol yang berisi jawaban } \\
\text { dari contoh soal tersebut. }\end{array}$ \\
\hline 3. & $\begin{array}{l}\text { Siswa dapat } \\
\text { mengerjakan } \\
\text { soal yang } \\
\text { berkaitan } \\
\text { dengan sudut } \\
\text { pusat, sudut } \\
\text { keliling, } \\
\text { panjang busur, } \\
\text { dan luas juring } \\
\text { lingkaran. }\end{array}$ & $\begin{array}{l}\text { a. Terdapat apersepsi yang membahas sedikit tentang panjang } \\
\text { busur serta juring lingkaran. Siswa dapat melihat gambarnya, } \\
\text { jika ingin mengetahui siswa bisa mengklik pada gambar } \\
\text { tersebut, sehingga akan muncul penjelasan dari gambar tersebut. } \\
\text { b. Ada kuis kecil berupa beberapa gambar lingkaran dengan sudut } \\
\text { didalamnya. Siswa memilih yang mana sudut pusat, dan yang } \\
\text { mana sudut keliling. Akan ada respon jika siswa mengklik pada } \\
\text { gambar, yaitu respon berupa gambar salah dan respon berupa } \\
\text { gambar benar. }\end{array}$ \\
\hline
\end{tabular}

\section{Validasi Desain}


Vol 1 No 22020 Desember 2020

Jurnal AlphaEuclidEdu

Peneliti meminta bantuan kepada 2 orang validator, yaitu guru matematika dan dosen pendidikan matematika FKIP Untan. Untuk guru sebagai juru materi dan pembelajaran, sedangkan dosen sebagai juru media, serta materi dan pembelajaran. Untuk menilai bahan ajar interaktif yang dikembangkan, peneliti mengacu kepada BSNP dan Yudhi Munadi. Dari BSNP, peneliti mengambil 3 komponen untuk menilai bahan ajar interaktif yang dikembangkan, yaitu: (1) kelayakan isi; (2) kelayakan bahasa; (3) kelayakan penyajian. Dari Yudhi Munadi lebih kepada media, seperti tombol navigasi, kandungan kognisi, dan lainnya. Lembar validasi ahli menggunakan nilai 1 sampai 4 perbutir penilaiannya, seperti ditampilkan pada tabel 2 .

Tabel 2. Kategori Penilaian Analisis Kelayakan

\begin{tabular}{cc}
\hline Kategori & Skor \\
\hline Sangat baik & 4 \\
\hline Baik & 3 \\
\hline Kurang & 2 \\
\hline Sangat kurang & 1 \\
\hline
\end{tabular}

Dengan kriteria penilaian kevalidan seperti pada tabel 3.

Tabel 3. Kriteria Penilaian Analisis Kelayakan

\begin{tabular}{ll}
\hline Rentang skor & Kategori kevalidan \\
\hline $3<\mathrm{P} \leq 4$ & Sangat valid \\
\hline $2<\mathrm{P} \leq 3$ & Valid \\
\hline $1<\mathrm{P} \leq 2$ & Kurang valid \\
\hline $0<\mathrm{P} \leq 1$ & Tidak valid \\
\hline
\end{tabular}

Lembar validasi dari ahli bahan ajar interaktif dan ahli materi dikumpulkan kemudian dianalisis kevalidannya menggunakan rumus sebagai berikut:

$$
P=\frac{\sum \text { hasil masing }- \text { masing butir }}{\text { banyak butir }}
$$

Sedangkan kriteria penilaian kelayakan bahan ajar interaktif seperti tabel 4.

Tabel 4. Hasil Penilaian Analisis Kelayakan

\begin{tabular}{ll}
\hline Nilai & Keterangan \\
\hline A & Sangat layak, dapat digunakan tanpa revisi. \\
\hline B & Layak, dapat digunakan dengan sedikit revisi. \\
\hline C & Kurang layak, dapat digunakan dengan banyak revisi. \\
\hline D & Tidak layak, tidak dapat digunakan. \\
\hline
\end{tabular}

Bahan ajar yang dibuat dikatakan berkualitas jika penilaian kedua pakar terhadap bahan ajar berada pada kategori valid atau sangat valid serta ahli menyatakan bahan ajar yang dikembangkan layak atau sangat layak.

\section{Revisi Desain}

Perbaikan desain dilaksanakan sehabis validasi. Terdapat sejumlah masukan dari validator untuk memperbaiki bahan ajar interaktif. Bahan ajar interaktif sebelum 
Vol 1 No 22020 Desember 2020

Jurnal AlphaEuclidEdu

direvisi disebut prototype 1 , kemudian setelah direvisi disebut prototype 2. Prototype 2 lah yang akan digunakan dalam ujicoba produk.

\section{Ujicoba Produk}

Hasil dari revisi desain, kemudian diujicobakan di kelas XI SMP Islam Bawari Pontianak. Sebelum mengujicobakan Prototype II, peneliti memberikan Pre-test, dan setelah diujicobakan, peneliti memberikan Post-test. Ujicoba produk dilaksanakan pada tanggal 1 dan 4 November 2019.

\section{Hasil Penelitian dan Pembahasan}

\subsection{Hasil Penelitian}

Bahan ajar interaktif yang sudah disusun tapi belum divalidasi disebut dengan Prototype I. Prototype I selanjutnya divalidasi oleh 2 orang, yaitu dosen sebagai juru media dan materi, serta guru sebagai juru materi. Hasil revisi bahan ajar interaktif disebut dengan Prototype II. Berikut hasil validasi Prototype II pada tabel 5 dan 6.

Tabel 5. Hasil validasi bahan ajar interaktif oleh ahli materi

\begin{tabular}{ccc}
\hline Skor & Kevalidan & Kelayakan \\
\hline 3,94 & Sangat valid & B \\
\hline
\end{tabular}

Tabel 6. Hasil validasi bahan ajar interaktif oleh ahli media

\begin{tabular}{ccc}
\hline Skor & Kevalidan & Kelayakan \\
\hline 3,38 & Sangat valid & B \\
\hline
\end{tabular}

Karena kevalidannya sangat valid, dan kelayakannya B, maka tidak dilakukan revisi lagi oleh peneliti. Hasil dari evaluasi bahan ajar interaktif (Prototype II) diimplementasikan dengan cara uji coba terbatas di SMP Islam Bawari Pontianak. Uji coba dilakukan dengan cara memberikan pre-tes kepada peserta didik sebelum menggunakan Prototype II dan post-tes setelah menggunakan Prototype II dalam pembelajaran materi Lingkaran. Tes tersebut diberikan untuk mengetahui indikatorindikator apa saja yang dimiliki oleh peserta didik. Berikut hasilnya dalam tabel 7.

Tabel 7. Persentase perolehan keterampilan peserta didik

\begin{tabular}{|c|c|c|c|c|}
\hline Keterampilan & Indikator & $\begin{array}{c}\text { Kode } \\
\text { Indikator }\end{array}$ & $\begin{array}{l}\text { Pre-test } \\
(\%)\end{array}$ & $\begin{array}{c}\text { Post-test } \\
(\%)\end{array}$ \\
\hline \multirow{3}{*}{$\begin{array}{l}\text { Keterampilan } \\
\text { Intelektual }\end{array}$} & $\begin{array}{l}\text { Menunjukkan hubungan panjang busur lingkaran } \\
\text { dengan sudut pusat lingkaran. }\end{array}$ & A & $0 \%$ & $58,33 \%$ \\
\hline & $\begin{array}{l}\text { Menunjukkan hubungan luas juring dengan sudut } \\
\text { pusat lingkaran. }\end{array}$ & B & $0 \%$ & $50 \%$ \\
\hline & $\begin{array}{c}\text { Menyelesaikan soal matematika yang berkaitan } \\
\text { dengan hubungan-hubungan antara sudut keliling, } \\
\text { sudut pusat, luas juring, dan panjang busur } \\
\text { lingkaran. }\end{array}$ & $\mathrm{C}$ & $0 \%$ & $20,83 \%$ \\
\hline
\end{tabular}

Prototype II diujicobakan di SMP Islam Bawari Pontianak. Siswa yang mengikuti ujicoba dihari pertama (1 november 2019) sebanyak 24 siswa, namun dihari kedua (4 november 2019) sebanyak 19 siswa, 5 siswa tidak hadir dikarenakan sakit. Ujicoba 
Vol 1 No 22020 Desember 2020

Jurnal AlphaEuclidEdu

dilakukan dengan cara memberikan tes pada saat sebelum dan sesudah penggunaan bahan ajar yang dikembangkan.

\subsection{Pembahasan}

Hasil dari tes yang dilakukan peneliti pada saat sebelum menggunakan bahan ajar interaktif menunjukkan bahwa untuk materi lingkaran, siswa masih mendapat kesulitan saat memahami materi. Hal demikian dapat dilihat pada tabel 7, dengan persentase $0 \%$ disetiap indikatornya. Untuk keterampilan intelektual yang dimiliki oleh siswa masih sangat rendah. Seluruh siswa hanya bisa menuliskan diketahui dan ditanya dari setiap soal. Adapula beberapa siswa yang berusaha untuk mengerjakannya, namun rumus yang digunakan salah. Sehingga salah dalam mengoperasikannya.

Hasil dari tes yang dilakukan peneliti pada saat setelah menggunakan bahan ajar interaktif, menunjukkan bahwa untuk materi lingkaran, siswa bisa memahami dengan baik materi yang disampaikan dengan bahan ajar interaktif. Hal ini dapat dilihat pada tabel 7, untuk perolehan keterampilan intelektual mengalami peningkatan. Hal ini didukung 58,33\% dari 24 siswa, mampu menyelesaikan soal tentang kaitan panjang busur dengan sudut pusat lingkaran. Untuk kemampuan siswa dalam menetapkan kaitan luas juring dan sudut pusat lingkaran, menurut peneliti dalam kategori sedang. Hal ini didukung 50\% dari 24 siswa, mampu menyelesaikan soal mengenai kaitan luas juring dan sudut pusat lingkaran. Sedangkan kemampuan menyelesaikan persoalan terkait hubungan-hubungan antara panjang busur, luas juring, sudut pusat, dan sudut keliling lingkaran. Menurut peneliti masih dalam kategori rendah. Hal ini didukung 20,83\% dari 24 siswa, mampu menyelesaikan soal matematika yang berkaitan dengan hubunganhubungan antara sudut keliling, luas juring, sudut pusat, dan panjang busur lingkaran. Namun mengalami peningkatan dari hasil sebelumnya. Dari uraian tersebut dapat diketahui bahwa, hasil tes yang diperoleh setelah menggunakan bahan ajar interaktif menunjukkan adanya peningkatan dari hasil sebelumnya. Hal tersebut dapat dilihat pada tabel 7, dimana setiap perolehan keterampilan mengalami peningkatan.

\section{Kesimpulan}

Simpulan yang bisa didapat dari penelitian ini adalah: 1) Bahan ajar interaktif yang dikembangkan dinyatakan layak. Bahan ajar ini dinyatakan sangat valid dan layak oleh para ahli, dengan kriteria kelayakan B. 2) Perolehan keterampilan peserta didik mengalami peningkatan setelah menggunakan bahan ajar interaktif yang dikembangkan.

\section{Referensi}

BSNP. (2007). Standar Proses Untuk Satuan Pendidikan Dasar dan Menengah. (Online).(http://bsnpindonesia.org/id/wpcontent/uploads/proses/Permen_41_Th2007.pdf, diakses tanggal 18 Juni 2018).

Munadi, Yudhi. (2008). Media Pembelajaran Sebuah Pendekatan Baru. Jakarta : Gaung Persada Press.

Munir. (2013). Multimedia - Konsep \& Aplikasi dalam Pendidikan. Bandung: Alfabeta. 
Vol 1 No 22020 Desember 2020

Jurnal AlphaEuclidEdu

Prastowo, Andi. (2012). Panduan Kreatif Membuat Bahan Ajar Inovatif. Yogyakarta: DIVA Press.

Prastya, Abi Krida. (2012). Proses Pembelajaran Musik Bagi Kelompok Band Just 4_U di SMA Bopkri 1 Yogyakarta. Yogyakarta : Universitas Negeri Yogyakarta.

Sanjaya, Wina. (2013). Perencanaan dan Desain Sistem Pembelajaran. Jakarta : KENCANA Prenadamedia Group.

Sugiyono. (2017). Metode Penelitian Kuantitatif, Kualitatif dan R\&D. Jakarta : Alfhabeta. 
Vol 1 No 22020 Desember 2020

Jurnal AlphaEuclidEdu

Received: 21/10/2020; Revised: 30/11/2020; Accepted: 08/12/2020

\title{
MISKONSEPSI SISWA DALAM MENYELESAIKAN SOAL HIMPUNAN BERDASARKAN TAHAPAN MASON
}

\author{
${ }^{1}$ Melianti, Dwi Andi, ${ }^{2}$ Yusmin, Edy, ${ }^{3}$ Nursangaji, Asep \\ 1,2,3Pendidikan Matematika FKIP Universitas Tanjungpura Pontianak \\ Email: andydwi108@gmail.com
}

\begin{abstract}
There are facts obtained through interviews and observations of students' answers that the VII grade students of SMP LKIA Pontianak are suspected of having misconceptions. Based on theses facts, the purpose of this research is to reveal the form of misconception based on Mason stages and the causes of the misconception. The subjects involved in this research were fifteen students. This research is a case study research with a descriptive method. Data collection tools used modified CRI diagnostic tests and interviews. Based on data analysis, the misconceptions experienced by students in completing set operations consisted of notation misconceptions, generalization and specialization. Researchers found out of the three forms of misconception, the most common is notation misconception. In the problem solving stage according to Mason consists of three stages, namely entry, attack, and review, students who experience misconceptions in two stages, namely at the entry stage, students experience notation misconceptions and at the review stage, students experience misconceptions of notation, generalization, and specialization. Researchers found the causes of misconceptions consisted of three factors, namely students' associative thinking, incomplete / wrong reasoning, and wrong intuition. Researchers found out of the three forms of misconception, the most common is wrong intuition.

Keyword: Causes of Misconceptions, Mason Stages, Misconceptions
\end{abstract}

\section{Pendahuluan}

Pembelajaran bidang studi matematika memiliki beberapa tujuan yang termuat dalam Permendiknas No. 22 tahun 2006, yaitu memahami, menjelaskan keterkaitan, dan mengaplikasikan konsep. Siswa dengan jenjang SMP/MTs/SMPLB dan sederajat, pengetahuan konseptual menjadi salah satu aspek yang terdapat dalam kompetensi yang termuat didalam Permendikbud No. 20 tahun 2016. Berdasarkan hal tersebut, pengetahuan konseptual sangat berarti, sehingga miskonsepsi (kesalahan dalam pengetahuan konseptual) harus diperkecil untuk terjadi dikalangan siswa. Edogawatte mengungkapkan bahwa ada 3 jenis kesalahan dalam menyelesaikan soal, yaitu salah algoritma (faulty algorithms), salah konsep (misconception), dan error (kesalahan akibat kurang teliti) (Edogawatte, 2011). Secara etimologis, miskonsepsi berasal dari bahasa inggris yaitu misconception, secara bahasa dapat diartikan sebagai kesalah pahaman. Cambridge Advance Learner's Dictionary mendefinisikan misconception is an idea that is wrong because it has been based on a failure to understanding a situation yang berarti miskonsepsi adalah sebuah ide yang salah karena didasarkan pada kegagalan untuk memahami suatu situasi.

Tracht menyatakan bahwa bidang studi matematika merupakan pembelajaran yang banyak menerapkan konsep-konsep (Tracht, 2011). Ozkan menyatakan konsep satu dengan konsep yang lainnya saling berkesinambungan, apabila satu diantara konsep yang saling berkesinambungan itu tidak dimengerti, sehingga akan menimbulkan dampak terhadap pemahaman konsep yang lainnya. Siswa dapat membuat pengertian sendiri terhadap suatu konsep hal ini disebabkan pemahaman yang rendah terhadap suatu konsep (Ozkan, 2011). Sesuai yang dikatakan Suparno dapat diambil kesimpulan bahwa miskonsepsi merupakan kata yang digunakan untuk mendeskripsikan suatu konsep yang tidak sesuai dengan pemahaman ilmiah atau pemahaman yang 
diterima oleh bidang yang terkait (Suparno, 2013). Kunh menyatakan bahwa miskonsepsi dapat menghambat pembelajaran baru (Kunh, 2009). Satu diantara topik ulasan yang dipelajari dijenjang SMP yaitu materi himpunan. Terkait materi himpunan ada beberapa tujuan pembelajaran yang ingin dicapai antaranya siswa diharapkan mampu mendefinisikan himpunan, mengetahui jeni-jenis himpunan, dan menyelesaikan opersai himpunan. Berdasarkan Standar kompetensi yang telah dibuat oleh Permendikbud yang diharapkan pada topik ini adalah memanfaatkan konsep himpunan dan diagram Venn untuk pemecahan masalah.

Fakta yang terjadi di lapangan berdasarkan hasil wawancara tak terstruktur dari guru matematika di SMP LKIA Pontianak kelas VII, didapatkan keterangan bahwa tujuan pembelajaran belum memuaskan berdasarkan tuturan guru tersebut, terutama pada sub menyelesaikan soal opersai himpunan. Akibatnya hasil belajar siswa kurang baik pada materi himpunan. Hal ini didukung oleh data rata-rata nilai 25 siswa kelas VII SMP LKIA Pontianak tahun ajaran 2019/2020 pada operasi himpunan sebesar 62,76 dikatagorikan tidak tuntas dengan KKM 75. Dari 25 jumlah siswa kelas VII 9 orang siswa tuntas atau 36\% siswa dan 16 orang siswa lainnya tidak tuntas atau 64\% siswa. Berdasarkan hasil prariset, didapatkan siswa yang mengalami salah pemahaman dalam mengubah notasi numerik untuk mendapatkan anggota himpunan $A$ yaitu $A=\{x \mid x \leq 10$, $\mathrm{x} \in$ bilangan asli $\}$, pekerjaan siswa menjawab " $\mathrm{A}=\{1,2,3,4,5,6,7,8,9\}$ " sedangkan yang sebenarnya adalah " $\mathrm{A}=\{1,2,3,4,5,6,7,8,9,10\}$ ”, hal tersebut mengidentifikasikan bahwa siswa tersebut mengalami miskonsepsi notasi dan siswa tersebut salah melakukan pengoperasian gabungan dari himpunan yaitu "AUB $=\{1,2$, $3,4,5,6,7,8\}$ " sedangkan yang sebenarnya adalah "AUB $=\{1,2,3,4,5,6,7,8,9\}$ " hal tersebut mengidentifikasikan bahwa siswa tersebut mengalami miskonsepsi penggeneralisasian.

Hal tersebut terjadi karena beberapa faktor satu diantaranya diduga telah terjadi kesalahan konsep siswa dalam operasi himpunan. Guru tersebut bertutur ada beberapa siswa yang tidak paham maksud soal dan salah membaca simbol yang dipakai dalam operasi himpunan sehingga dalam mencari hasil dari operasi tersebut mereka mendapat jawaban yang keliru. Adanya kesalahan konsep ini perlu dianalisis untuk mengetahui bentuk miskonsepsi yang dialami dan faktor penyebabnya. Hasan mengemukakan suatu metode yang digunakan untuk mengenali miskonsepsi sekaligus memilah siswa yang paham konsep dan yang tidak paham konsep (dalam Tayubi, 2005). Metode yang diajukan tersebut bernama CRI (Certainty of Response Index). Tes pemahaman konsep yang dilengkapi oleh CRI termodifikasi oleh Aliefman Hakim ini yang digunakan oleh peneliti pada penelitian ini. CRI merupakan suatu skala ukuran tingkat keyakinan yang telah ditetapkan untuk pihak-pihak yang dijadikan sebagai sempel dalam sebuah penelitian ketika menjawab setiap pertanyaan yang terdapat di dalam soal. CRI termodifikasi didasarkan pada suatu skala dan diberikan bersamaan dengan setiap jawaban dan alasan jawaban tersebut.

Depdiknas (2006: 148) menyatakan bahwa bidang studi pembelajaran matematika untuk tahapan menyelesaikan masalah adalah satu di antara tujuan yang hendak dicapai 
dalam pembelajarannya. Dalam menyelesaikan suatu masalah, siswa harus melewati beberapa tahap yaitu mengidentifikasi, menyelesaikan, dan membuat hubungan di antara beberapa hukum atau teori (Siregar, 2010). Berdasarkan pernyataan tersebut, kemampuan dalam menyelesaikan masalah sangat diperlukan dalam menghadapi suatu masalah. Tahapan penyelesaian masalah mampu dirambah dengan berbagai pengamatan yang didasarkan atas tahapan Polya, yaitu memahami, merencanakan, melaksanakan, dan melihat kembali. Ada juga, tahapan penyelesaian masalah mampu dirambah dengan tahapan Mason , dkk (2010). Menurut Mason terdapat tiga tahapan yang dilalui oleh seseorang untuk menyelesaikan masalah, yaitu entry, attack, dan review (Mason, 2010).

Tahapan penyelesaian masalah yang dikemukaan Polya (1973) sejalan dengan tahapan yang dikemukakan oleh Mason, dkk (2010) (Helda, 2016). Hal ini didukung oleh pernyataan Lin (2007) yang menyatakan bahwa tahapan penyelesaian masalah Mason didasarkan oleh pemikiran Polya. Dengan pembagian tahapan Mason membantu peneliti untuk menemukan jenis miskonsepsi yang tejadi berdasarkan tahapan dalam menyelesaikan masalah. Hal ini didukung oleh penelitian yang dilakukan Karolin (2016) yang berjudul tentang kesalah pahaman konsep dalam menyelesaikan soal aljabar siswa kelas VIII berdasarkan proses berpikir Mason yang didapatkan kesimpulan bahwa pada tahap entry dan review yang dicetuskan oleh Mason pada penelitian Karolin siswa tidak mengalami kesalah pahaman konsep, namun pada tahap attack siswa mengalami kesalah pahaman konsep dalam materi aljabar.

Berdasarkan paparan di atas peneliti sangat terdorong untuk mengetahui apa saja bentuk miskonsepsi yang dialami siswa saat menyelesaikan soal operasi himpunan berdasarkan tahapan Mason di kelas VII sekolah menengah pertama dan penyebab miskonsepsi yang dialami siswa saat menyelesaikan soal operasi himpunan. Tujuan yang ingin dicapai peneliti adalah untuk mengungkap bentuk miskonsepsi yang dialami siswa saat menyelesaikan soal operasi himpunan berdasarkan tahapan Mason di kelas VII sekolah menengah pertama dan untuk mengungkap penyebab miskonsepsi yang dialami siswa tersebut.

\section{Metode Penelitian}

Metode deskriptif adalah metode yang dipakai dalam penelitian ini, dengan jenis penelitian case study. Adapun yang menjadi pertimbangan memilih penelitian studi kasus antara lain karena penelitian ini memuaskan perhatian pada suatu kasus yaitu siswa yang mengalami miskonsepsi dalam suatu kelas. Dalam penelitian ini akan mengungkap miskonsepsi siswa dalam menyelesaiakan soal operasi himpunan berdasarkan tahapan Mason dan penyebab terjadinya miskosepsi. Miskonsepsi dapat ditemukan dari jawaban pada tes diagnostic CRI termodifikasi.

Tes pemahaman konsep (teknik tes) dan wawancara (teknik non tes) merupakan teknik pengumpulan data yang dipergunakan oleh peneliti dalam penelitian ini. Soal tes yang diberikan yaitu tes diagnostik dalam bentuk pilihan ganda dengan alasan sebanyak 4 soal yang memenuhi indikator pemahaman konsep notasi, penggeneralisasian, penspesialisasian dan indikator tahapan Mason pada materi operasi himpunan. 
Instrument dalam suatu penelitian perlu divalidasi untuk mengecek kelayakan suatu instrument dipergunakan, dalam penelitin ini terdiri dari 2 validator yaitu yang berasal dari dosen FKIP Matematika UNTAN DAN guru matematika kelas VII SMP LKIA Pontianak. Wawancara dalam penelitian ini dilakukan pada subjek yang diambil secara acak sebanyak empat orang subjek dengan kategori dari yang paling banyak melakukan kesalahan sampai yang paling sedikit yang melakukan kesalahan. Data miskonsepsi subjek dipaparkan sesuai dengan instrument tes diagnostik dalam bentuk pilihan ganda dengan alasan.

Pemilihan subjek yang digunakan dalam penelitian ini didasarkan oleh hasil tes yang telah dijawab oleh siswa diamana tes terebut dilengkapi kriteria CRI yang wajib diisi oleh siswa berdasarkan kenyataan yang ada. Sebanyak 15 siswa kelas VII SMP LKIA Pontianak, peneliti melakukan pengidentifikasian pada jawab masing-masing kepada calon subjek penelitian ini. Dari hasil penelitian tersebut, peneliti memilah siswa yang paham konsep, miskonsepsi, dan tidak paham konsep berdasarkan pedoman analisis untuk tes diagnostic CRI termodifikasi. Subjek yang dipilih adalah jawaban benar alasannya salah dan nilai CRInya (> 2,5), jawaban salah alasannya benar dan nilai CRInya (> 2,5), jawaban salah alsannya salah dan nilai CRInya (> 2,5). Setelah ditentukan siswa yang mengalami miskonsepsi, peneliti melakukan analisis bentuk miskonsepi yang terjadi yaitu terdiri atas miskonsepsi notasi, miskonsepsi penggeneralisasi, dan miskonsepsi penspesialisasian berdasarkan tahapan Mason yang terdiri atas tahapan entry, attack, dan review dan setelah mengetahui bentuk miskonsepsi yang terjadi peneliti melakukan wawancara untuk mengetahui penyebab miskonsepsi yang terjadi pada siswa tersebut. Tahap-tahap analisis yang digunakan dalam penelitian ini adalah data reduction, data display, dan conclusion drawing.

\section{Hasil Penelitian dan Pembahasan}

\subsection{Hasil Penelitian}

Tujuan penelitian ini adalah mengungkap bentuk-bentuk miskonsepsi berdasarkan tahapan Mason dan penyebab miskonsepsi menggunakan yang berasal dari subjek pada materi operasi himpunan. Subjek dalam penelitian ini berjumlah 15 subjek kelas VII SMP LKIA. Miskonsepsi notasi, penggeneralisasi, dan penspesialisasian adalah bentuk miskonsepsi yang terjadi pada siswa dalam menyelesaikan soal operasi himpunan. Penyebab miskonsepsi siswa adalah berasal dari pemikiran asosiatif, reasoning yang tidak lengkap atau salah, dan intuisi yang salah. Berikut ini untuk Tabel 1 dan Tabel 2 merupakan hasil rekapitulasi data yang didapat oleh peneliti setelah melakukan penelitian yang sebenarnya.

Tabel 1 Rekap Data Bentuk Miskonsepsi Siswa

\begin{tabular}{|c|c|c|c|c|c|}
\hline \multirow{2}{*}{$\begin{array}{l}\text { Jumlah } \\
\text { Subjek }\end{array}$} & \multirow{2}{*}{ No soal } & \multirow{2}{*}{ Tahapan Mason } & \multicolumn{3}{|c|}{ Miskonsepsi } \\
\hline & & & MN & MG & MS \\
\hline \multirow{5}{*}{15} & \multirow{5}{*}{1} & \multirow{2}{*}{ Entry } & 3 & & \\
\hline & & & $20 \%$ & & \\
\hline & & \multirow{2}{*}{ Attack } & 8 & & \\
\hline & & & $53,33 \%$ & & \\
\hline & & Review & - & - & - \\
\hline
\end{tabular}


Vol 1 No 22020 Desember 2020

Jurnal AlphaEuclidEdu

\begin{tabular}{|c|c|c|c|c|}
\hline & & - & - & - \\
\hline \multirow{6}{*}{2} & \multirow{2}{*}{ Entry } & 8 & & \\
\hline & & $53,33 \%$ & & \\
\hline & \multirow{2}{*}{ Attack } & 8 & & \\
\hline & & $53,33 \%$ & & \\
\hline & \multirow{2}{*}{ Review } & - & - & - \\
\hline & & - & - & - \\
\hline \multirow{5}{*}{3} & Entry & & & \\
\hline & \multirow[b]{2}{*}{ Attack } & & 2 & \\
\hline & & & $\frac{3}{20 \%}$ & \\
\hline & \multirow{2}{*}{ Review } & - & - & - \\
\hline & & - & - & - \\
\hline \multirow{5}{*}{4} & Entry & & & \\
\hline & \multirow{2}{*}{ Attack } & & 1 & 1 \\
\hline & & & $6,67 \%$ & $6,67 \%$ \\
\hline & \multirow{2}{*}{ Review } & - & - & - \\
\hline & & - & - & - \\
\hline
\end{tabular}

Keterangan:

MN: Miskonsepsi Notasi

MG: Miskonsepsi Penggeneralisasian

MS: Miskonsepsi penspesialisasian

Tabel 2 Rekap Data Penyebab Miskonsepsi

\begin{tabular}{|l|l|l|l|l|}
\hline No & Bentuk & Penyebab & \multicolumn{2}{|l|}{} \\
\cline { 3 - 5 } Soal & Miskonsepsi & PAS & RTL & IYS \\
\hline 1 & MN & 1 & 1 & 4 \\
\hline 2 & MN & & 3 & \\
\hline 3 & MG & & & 2 \\
\hline 4 & MS & & & 1 \\
\hline
\end{tabular}

Keterangan:

PAS :Pemikiran Asosiatif Siswa

RTL:Reasoning yang Tidak Lengkap/Salah

IYS :Intuisi Yang Salah

\subsection{Pembahasan}

Penelitian tentang Analisis miskonsepsi siswa berdasarkan tahapan Mason di kelas VII Sekolah Menengah Pertama dalam menyelesaikan soal operasi himpunan dilaksanakan pada hari kamis, 9 Juli 2020 kepada 15 siswa dan wawancara dilakukan pada hari rabu, 15 Juli 2020. Penelitian ini dilakukan secara daring karena pada saat penelitian negara Indonesia terpapar virus Covid-19, jadi belajar dan pembelajaran di sekolah dilakukan secara daring. Soal tes yang diberikan yaitu tes diagnostik dalam bentuk pilihan ganda dengan alasan sebanyak 4 soal yang memenuhi indikator pemahaman konsep notasi, penggeneralisasian, penspesialisasian dan indikator tahapan Mason pada materi operasi himpunan. Dalam membagikan instrument soal kepada 25 siswa yang ada di kelas 7 SMP LKIA, peneliti menggunakan aplikasi whatsapp untuk membagikan link soal yang dibuat menggunakan google form, dan yang merespon dari 
25 siswa tersebut hanya 15 siswa saja disebabkan oleh berbagai faktor yaitu keterbatasn alat komunikasi moderen contohnya hp, tidak memiliki kuota pada saat waktu tersebut, sinyal yang kurang mendukung dan ada beberapa siswa yang sengaja tidak mengerjakannya. Saat wawancara peneliti melakukan wawancara daring menggunakan chat aplikasi whatsapp kepada empat subjek berdasrkan kriteria yang telah ditetapkan sebelumnya.

Pada soal nomor 1 dengan pertanyaan tentang mengungkapkan notasi dalam himpunan secara verbal ke simbolik terdapat 2 tahapan dalam Mason yang dilalui siswa yang mengami miskonsepsi yaitu tahapan entry dan tahapan attack. Pada tahapan entry ada tiga subjek atau $20 \%$ subjek yang mengalami miskonsepsi, bentuk miskonsepsi yang dialami subjek adalah miskonsepsi notasi. Bentuk miskonsepsi notasi yang terjadi dalam tahapan entry adalah salah pemahaman dalam menentukan notasi dalam himpunan secara verbal ke simbolik pada penulisan tabulasi anggota himpunan dari himpunan yang diketahui didalam soal. Pada tahapan attack ada delapan subjek atau 53,33\% subjek yang mengalami miskonsepsi, bentuk miskonsepsi yang dialami subjek adalah miskonsepsi notasi. Bentuk miskonsepsi notasi yang terjadi dalam tahapan attack adalah salah pemahaman dalam penulisan notasi gabungan dan irisan. LERARN (2008) menyatakan bahwa miskonsepsi notasi yaitu penafsiran yang keliru pada sebuah notasi. Berdasarkan hasil wawancara diketahui penyebab miskonsepsi yang dialami subjek pada soal nomor 1 yaitu pemikiran asosiatif siswa, reasoning yang tidak lengkap/salah, dan intuisi yang salah.

Pada soal nomor 2 dengan pertanyaan tentang Siswa menyatakan notasi dalam himpunan secara simbolik ke verbal terdapat 2 tahapan dalam Mason yang dilalui siswa yang mengalami miskonsepsi yaitu tahapan entry dan tahapan attack. Pada tahapan entry ada delapan subjek atau 53,33\% subjek yang mengalami miskonsepsi, bentuk miskonsepsi yang dialami subjek adalah miskonsepsi notasi. Bentuk miskonsepsi notasi yang terjadi dalam tahapan entry adalah salah pemahaman notasi dalam himpunan secara simbolik ke verbal pada penulisan tabulasi anggota himpunan. Pada tahapan attack ada delapan subjek atau 53,33\% subjek yang mengalami miskonsepsi, bentuk miskonsepsi yang dialami subjek adalah miskonsepsi notasi. Bentuk miskonsepsi notasi yang terjadi dalam tahapan attack adalah salah pemahaman notasi dalam himpunan secara simbolik ke verbal pada dan himpuan yang diketahui didalam soal dan operasi selisih himpunan. Berdasarkan hasil wawancara diketahui penyebab miskonsepsi yang dialami subjek untuk soal nomor 2 yaitu reasoning yang tidak lengkap/salah.

Pada soal nomor 3 dengan pertanyaan tentang siswa menentukan hasil operasi gabungan dan irisan pada himpunan terdapat 1 tahapan dalam tahapan Mason yang dilalui siswa yang mengalami miskonsepsi yaitu tahapan attack. Pada tahapan attack ada tiga subjek atau $20 \%$ subjek yang mengalami miskonsepsi, bentuk miskonsepsi yang dialami subjek adalah miskonsepsi penggeneralisasian. Bentuk miskonsepsi penggeneralisasi yang terjadi dalam tahapan attack adalah kesalahan pada konsep yang dibutuhkan saat melakukan operasi himpunan irisan, gabungan. Menurut Ashlock menyatkan bahwa miskonsepsi penggeneralisasi adalah suatu kesalahan yang dialami 
oleh siswa yang bermula dari pernyataan yang bersifat umum secara berlebihan terhadap sebuah alasan dan siswa tersebut langsung menarik kesimpulan setelah mempunyai informasi yang lebih untuk menyimpulkan. Berdasarkan hasil wawancara diketahui penyebab miskonsepsi yang dialami subjek untuk soal nomor 3 yaitu intuisi yang salah.

Pada soal nomor 4 dengan pertanyaan tentang siswa menentukan hasil operasi gabungan, komplemen, dan selisih pada himpunan terdapat 1 tahapan dalam tahapan Mason yang dilalui siswa yang mengalami miskonsepsi yaitu tahapan attack. Pada tahapan attack ada satu subjek atau $6,67 \%$ yang mengalami bentuk miskonsepsi penggeneralisasian dan pada tahapan attack ada satu subjek atau 6,67\% yang mengalami bentuk miskonsepsi penspesialisasian. Bentuk miskonsepsi penggeneralisasi yang terjadi dalam tahapan attack adalah kesalahan pada konsep yang dibutuhkan saat melakukan operasi himpunan gabungan dan bentuk miskonsepsi penspesialisasian yang terjadi dalam tahapan attack adalah menganggap sebuah konsep dapat digunakan untuk konsep lainnya dalam melakukan operasi gabungan himpunan. Menurut Ashlock (2008: 11) menyatkan bahwa miskonsepsi penspesialisasian adalah bentuk miskonsepsi yang diberasal dari suatu pemikiran yang mengkhususkan sesutu secara berlebihan selama proses pembelajaran. Berdasarkan hasil wawancara diketahui penyebab miskonsepsi yang dialami subjek untuk soal nomor 4 yaitu intuisi yang salah.

Berdasarkan tahapan yang dicetuskan oleh Mason, siswa mengalami miskonsepsi pada tahapan entry dan attack. Tahapan entry adalah tahapan dimulai ketika pertama kali menghadapi pertanyaan dan berakhir ketika telah memulai untuk mencoba memecahkannya, dan pada akhirnya mereka akan menemukan apa yang diketahui dan ditanyakan, pada tahapan ini miskonsepsi yang terjadi pada subjek adalah miskonsepsi notasi, dimana subjek mengalami salah pemahaman dalam menyatakan notasi dalam himpunan secara verbal ke simbolik terbukti berdasarkan Tabel 1 bahwa untuk soal nomor 1 sebanyak tiga subjek atau 20\% subjek yang mengalami miskonsepsi notasi pada tahapan entry dan subjek mengalami salah pemahaman dalam menyatakan notasi dalam himpunan secara simbolik ke verbal terbukti berdasarkan Tabel 1 bahwa untuk soal nomor 2 sebanyak delapan subjek atau 53,33\% subjek yang mengalami miskonsepsi notasi pada tahapan entry.

Pada tahapan attack adalah tahapan bagian yang paling penting dari aktivitas matematika yang dilakukan untuk menyelesaikan masalah, pada tahapan ini miskonsepsi yang terjadi pada subjek adalah miskonsepsi notasi, miskonsepsi penggeneralisasian, dan miskonsepsi penspesialisasian. Miskonsepsi notasi terjadi akibat subjek mengalami salah pemahaman dalam menyatakan notasi dalam himpunan secara verbal ke simbolik terbukti berdasarkan Tabel 1 bahwa untuk soal nomor 1 sebanyak delapan subjek atau 53,33\% subjek mengalami miskonsepsi notasi pada tahapan attack dan subjek mengalami salah pemahaman dalam mengungkapkan notasi dalam himpunan secara simbolik ke verbal terbukti berdasarkan Tabel 1 bahwa untuk soal nomor 2 sebanyak delapan subjek atau 53,33\% subjek mengalami miskonsepsi notasi pada tahapan attack. Miskonsepsi penggeneralisasin terjadi akibat subjek 
mengalami salah pada konsep yang dibutuhkan saat melakukan operasi himpunan terbukti berdasarkan Tabel 1 bahwa untuk soal nomor 3 sebanyak tiga subjek atau 20\% subjek mengalami miskonsepsi penggeneralisasian pada tahapan attack. Miskonsepsi penspesialisasian terjadi akibat subjek yang menganggap sebuah konsep dapat digunakan untuk konsep lainnya terbukti berdasarkan Tabel 1 bahwa untuk soal nomor 4 sebanyak satu subjek atau $6,67 \%$ yang mengalami miskonsepsi penspesialisasian.

Tahapan review tahapan dimana siswa melakukan meninjau kembali dan memeriksa yang mungkin saja terjadi kesalahan-kesalahan pada saat pengerjaan, pada tahapan ini peneliti tidak dapat menganalisis miskonsepsi yang terjadi, karena subjek tidak menuliskan tahapan pengecekan kembali jawaban yang telah dibuatnya terbukti dari foto pengerjaan subjek yang telah dianalisis dan pada Tabel 1. Dari pembahasan di atas dapat dilihat bahwa berdasarkan tahapan Mason yang terdiri atas tahapan entry, attack, dan review, siswa banyak mengalami miskonsepsi pada tahapan entry dan tahapan attack. Dari dua tahapan tersebut yang sering terjadinya miskonsepsi yaitu pada tahapan attack. Hal ini sejalan dalam penelitian Karolin (2016) pada hasil penelitiannya menunjukan bahwa dari tiga tahapan yang dicetuskan oleh Mason, pada tahapan attack siswa mengalami miskonsepsi.

Suparno menyatakan bahwa penyebab miskonsepsi yang berasal dari siswa terdiri atas prakonsepsi, pemikiran asosiatif, pemikiran humanistik, reasoning yang tidak lengkap/salah, intuisi yang salah, tahap perkembangan kognitif siswa, kemampuan siswa, minat belajar (Suparno, 2013). Berdasarkan delapan faktor yang menyebabkan miskonsepsi bersal dari siswa, lima dari tiga faktor tersebut tidak diteliti oleh peneliti dalam penelitian ini yaitu prakonsepsi karena sebelum melaksanakan penelitian yang sebenarnya peneliti harus melakukan wawancara dan tes diagnostik kepada para siswa, pemikiran humanistik tidak diambil karena pemikiran humanistik memandang semua benda dari pandangan manusiawi, sisi-sisi manusiawi yang dimaksudkan adalah adanya keterlibatan otak dan emosi setiap individu dalam kegiatan pembelajaran, jadi peneliti harus melakukan penelitian awal untuk mengetahui pemikiran humanistik setiap siswa setiap kegitan pelajarannya, tahap perkembangan kognitif siswa karena dalam penelitian ini dilakukan kepada siswa kelas VII SMP, sehingga menurut Piaget umur siswa tersebut berada pada masa operasional dengan rentang umur dari sebelas tahun hingga dewasa (dalam Ormrod, 2009 dengan hal ini menyebabkan peneliti beranggapan bahwa siswa mempunyai perkembangan kognitif yang sama, dan untuk minat belajar serta kemampuan siswa peneliti harus menyebarkan angket atau instrument yang tepat untuk mengetahuinya tidak hanya bisa dilakukan dengan wawancara.

Dalam penelitian ini ditemukan penyebab terjadinya miskonsepsi pada subjek disebakan oleh beberapa faktor, yang berasal dalam diri subjek sendiri yaitu pemikiran asosiatif siswa, Reasoning yang tidak lengkap/salah, dan intuisi yang salah. Penyebab miskonsepsi yang paling banyak terjadi adalah Intuisi Salah terlihat dalam Tabel 2.

\section{Kesimpulan}

Kesimpulan yang dapat diperoleh setelah melakukan penelitian yaitu: (1) a) 
Bentuk miskonsepsi yang dialami siswa kelas VII SMP LKIA Pontianak pada materi operasi himpunan adalah bentuk miskonsepsi notasi, miskonsepsi penggeneralisasi, dan miskonsepsi penspesialisasi. Dari tiga bentuk miskonsepsi yang dialami siswa, bentuk miskonsepsi yang paling sering terjadi adalah miskonsepsi notasi. b) Berdasarkan tahapan yang dibuat Mason yang terdiri atas tahapan entry, attack dan review, siswa kelas VII SMP LKIA Pontianak mengalami miskonsepsi pada dua tahapan tersebut yaitu pada tahapan entry dan tahapan attack. Pada tahapan entry siswa mengalami miskonsepsi notasi dan pada tahapan attack siswa mengalami miskonsepsii notasi, miskonsepsi penggeneralisasi dan miskonsepsi penspesialisasian. Dari dua tahapan tersebut yang sering terjadinya miskonsepsi yaitu pada tahapan attack. (2) Penyebab miskonsepsi yang dialami siswa kelas VII SMP LKIA Pontianak disebabkan oleh pemikiran asosiatif siswa, reasoning yang tidak lengkap/salah, dan intuisi yang salah. Dari tiga penyebab miskonsepsi yang dialami siswa, penyebab yang paling banyak terjadi adalah intuisi yang salah.

\section{Referensi}

Ariefia, Evanty, Hellda. 2016. Proses Berpikir Siswa dalam Menyelesaikan Permasalahan pada Materi Trigonometri. Jurnal Pembelajaran Matematika. 1(28). Ashlock. (2008). Misconception and Error Patterns. [online]. http://ptgmedia.pearsoncmg.com/images/9780135009109/downloads/Ashlock_Ch 1_MisconceptionsandErrorPatterns. pdf, diakses tanggal 23 November 2019.

Edogawatte, G. 2011. Secondary School Students' Misconceptions in Algebra. Department of Curriculum, Teaching, and Learning University of Toronto.

LEARN. (2008). Algebra: Some Common Misconceptions. [Online]. http://www.learnquebec.ca/export/sites/learn/en/content/curriculum/mst/document s/algemisc. pdf, diakses tanggal 23 November 2019.

Lin, F. L. 2007. Designing Mathematics Conjecturing Activities to Foster Thinking and Constructing Actively.

[Online]. (http://cried.tsubasa.ac.jp/math/apec/apec2007/paper. pdf, diakses tanggal 4 Febuari 2020).

Mason, J., Burton, L., \& Stacey K. 2010. Thinking Mathematically. Second Edition. Wokingham. UK: Addison Wesley.

Ormord, J.E. (2009). Psikologi Pendidikan Jilid 1. Jakarta: Erlangga.

Ozkan, E.M. 2011. Misconceptions in Radicals in High School Mathematics. ProcediaSocial and Behavioral Sciences (15), 120-127.

Polya, G. 1973. How To Solve It Second Edition. New Jersey: Princeton University Press.

Siregar, Eveline, \& Nara, Hartini. 2010. Teori Belajar dan Pembelajaran. Bogor: Ghalia Indonesia.

Suparno, Paul. 2005. Miskonsepsi dan Perubahan Kosep dalam Pendidikan Fisika. Jakarta: Grasindo.

T, Natalia, Karolin. Miskonsepsi pada Penyelesaian Soal Aljaba Siswa Kelas VIII 
Vol 1 No 22020 Desember 2020

Jurnal AlphaEuclidEdu

Berdasarkan Proses Berpikir Mason. Jurnal Pendidkan. 1(10), 1917-1925.

Tayubi, Y. R., (2005). Identifikasi miskonsepsi pada konsep-konsep fisika dengan menggunakan CRI Certainty of Response Indeks). [online]. (http://file.upi.edu/direktori/jurnal/jurnalmimbar_pendidikan/mimbar_no_32005/I dentifikasi_Miskonsepsi_Pada_Konsep_Konsep_Fisika_Menggunakan_Certainty _Of_Response_Index_(CRIs). pdf, diakses tanggal 24 November 2019. 
Vol 1 No 22020 Desember 2020

Jurnal AlphaEuclidEdu

Received: 25/11/2020; Revised: 30/11/2020; Accepted: 08/12/2020

\title{
TINGKAT KEPUASAN MAHASISWA TERHADAP LAYANAN BIMBINGAN TUGAS AKHIR
}

\author{
$\mathbf{1}_{\text {Asep Nursangaji, }}{ }^{2}$ Hamdani \\ ${ }^{1,2}$ Pendidikan Matematika FKIP Universitas TanjungpuraUNTAN Pontianak \\ Email: nursangaji@yahoo.com
}

\begin{abstract}
Nowadays, there are several universities in West Kalimantan that have mathematics education department, such as IKIP Pontianak, STKIP Singkawang, and STKIP Sintang. This condition provides great opportunities for prospective students who want to become mathematics teachers in schools, especially high schools. On the other side, the presence of mathematics education department in several universities in West Kalimantan is a challenge for Mathematics Education department FKIP Untan. One of the challenges that come is how to produce graduates who can compete in the world of work. In order to create qualified mathematics teacher candidates, it is very important for the FKIP Untan mathematics education department to provide one of the quality final assignment guidance services so that final year students can have quality final projects. This study will examine how high the level of student satisfaction with final assignment guidance services in Mathematics Education Department FKIP Untan. Furthermore, it will be known what service items should be improved and developed in an effort to increase student satisfaction. The level of student satisfaction with the final assignment guidance service is $0 \%$ of students are not satisfied, $0 \%$ of students are not satisfied, 9\% of students are satisfied, 30\% of students are quite satisfied, and $61 \%$ of students are very satisfied. It can be concluded that the final year students of the Mathematics Education Department, Teaching and Education Faculty, Tanjungpura University are satisfied with the services provided by the supervisors

Keywords: Satisfaction; academic services; final assignment guidance.
\end{abstract}

\section{Pendahuluan}

Perguruan Tinggi sebagai salah satu lembaga pendidikan pada dasarnya adalah organisasi jasa, yakni memberikan layanan pendidikan pada masyarakat. Sebagai organisasi jasa, Perguruan Tinggi dituntut untuk memberikan pelayanan yang terbaik kepada pelanggan, khususnya kepada mahasiswa karena akan mempengaruhi kualitas lulusan yang dihasilkan. Fakultas Keguruan dan Ilmu Pendidikan (FKIP) Untan sebagai salah satu organisasi layanan publik, tentu juga memiliki tantangan yang sama dengan FKIP/lembaga Kependidikan Perguruan Tinggi lainnya. FKIP mengalami kondisi persaingan yang sama sehingga harus memikirkan strategi peningkatan kualitas pelayanan yang memberi kepuasan kepada mahasiswanya.Sejauh ini, Prodi Pendidikan Matematika FKIP UNTAN telah berusaha semaksimal mungkin untuk memberikan layanan akademik kepada mahasiswa sebagai konsumennya. Karena pelayanan akademik yang berkualitas akan menciptakan lulusan/mahasiswa yang berkualitas sehingga mampu bersaing di era globailsasi/ era revolusi industri 4.0. Layanan akademik tersebut, seperti: perkuliahan, kurikulum, bimbngan/konsultasi akademik, praktikum, bimbingan tugas akhir, dan lain-lain (Tampubolon, 2001). Salah satu indeks penilaian kepuasan mahasiswa dalam layanan akademik di FKIP Universitas Tanjungpura adalah bimbingan penulisan tugas akhir. Dalam kehidupan perkuliahan, setiap mahasiswa pasti diberikan dosen pembimbing seminar dan skripsi yang berfungsi sebagai penunjuk arah menulis tugas akhir sebagai syarat untuk mendapatkan gelar sarjana pendidikan.. Dari indeks tersebut tentunya harus diperhatikan aspek kemudahan dan kenyamanan interaksi antara mahasiswa sebagai 
Vol 1 No 22020 Desember 2020

Jurnal AlphaEuclidEdu

Received: 25/11/2020; Revised: 30/11/2020; Accepted: 08/12/2020

stakeholder dan dosen sebagai penyedia layanan, sehingga dapat dihasilkan sebuah produk ilmiah yang berkualitas.

\section{Metode Penelitian}

\section{Pendekatan Penelitian}

Penelitian ini menggunakan Pendekatan kuantitatif dengan metode deskriptif. penggunaan metode deskriptif bertujuan untuk menggambarkan secara jelas tentang kepuasan mahasiswa terhadap kualitas layanan akademik pada prodi pendidikaan matematika FKIP Untan tahun akademik 2019/2020. Bentuk penelitian yang digunakan adalah survey studies.

\section{Waktu dan Tempat Penelitian}

Penelitian ini berlokasi di Prodi Pendidikan Matematika FKIP UNTAN, yang dilakukan pada bulan Mei - Oktober 2020

\section{Populasi dan Sampel}

Populasi dalam penelitian ini adalah mahasiswa tingkat akhir Prodi Pendidikan Matematika FKIP Untan untuk data kepuasan layanan bimbingan tugas akhir. Pembatasan tersebut dimaksudkan untuk menjaring mahasiswa yang telah benar-benar merasakan layanan bimbingan tugas akhir, sehingga mereka bisa menilai tingkat kepuasan serta tingkat urgensi dari pelayanan tersebut

Untuk pengambilan sampel survei, peneliti menggunakan probability sampling, yaitu teknik pengambilan sampel yang memberikan peluang yang sama bagi setiap unsur (anggota) populasi untuk dipilih menjadi anggota sampel, dan teknik yang dipilih adalah proportionate random sampling, yaitu pengambilan anggota sampel dilakukan dengan memperhatikan proporsi yang ada dalam populasi itu.

Analisis Data

Analisis data menggunakan analisis deskriptif dengan mencari rata-rata tingkat kepuasan mahasiswa untuk masing-masing dimensi dan secara umum kemudian dibuat interval. Rentang tersebut akan digunakan sebagai dasar kriteria tingkat kepuasan mahasiswa.

\section{Hasil dan Pembahasan}

\section{Tingkat Kepuasan Mahasiswa Terhadap Aspek - Aspek Layanan Bimbingan} Akademik

\section{Aspek Availabilitas}

Kepuasan mahasiswa terhadap layanan bimbingan tugas akhir pada aspek availabilitas diukur dengan 4 pernyataan dengan 5 tingkat kepuasan. 5 tingkat kepuasan yang digunakan adalah tidak puas, kurang puas, puas, cukup puas, dan sangat puas. Berdasarkan hasil analisis data kuisioner yang diisi oleh 150 mahasiswa sebagai responden, didapatkan data tingkat kepuasan mahasiswa terhadap layanan bimbingan akademik yang ditunjukan dalam gambar 1 . 
Vol 1 No 22020 Desember 2020

Jurnal AlphaEuclidEdu

Received: 25/11/2020; Revised: 30/11/2020; Accepted: 08/12/2020

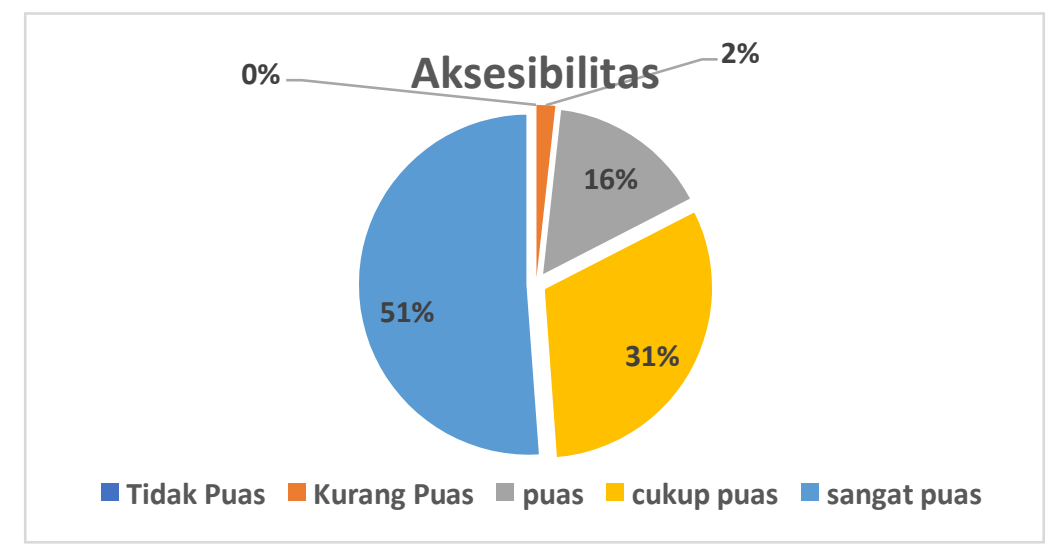

Gambar 1. Diagram tingkat kepuasan mahasiswa terhadap layanan bimbingan tugas akhir aspek availabilitas

Berdasarkan diagram di atas, dari 150 mahasiswa, sebanyak 0 mahasiswa merasa tidak puas, 3 mahasiswa merasa kurang puas, 24 mahasiswa merasa puas, 47 mahasiswa merasa cukup puas, dan 77 mahasiswa merasa sangat puas dengan layanan bimbingan tugas akhir yang diberikan oleh para dosen yang bertupoksi sebagai dosen pembimbing skripsi di Program Studi Pendidikan Matematika Fakultas Keguruan dan Ilmu Pendidikan Universitas Tanjungpura

\section{Aspek Penguasaan Materi}

Kepuasan mahasiswa terhadap layanan bimbingan tugas akhir pada aspek penguasaan materi diukur dengan 6 pernyataan dengan 5 tingkat kepuasan. 5 tingkat kepuasan yang digunakan adalah tidak puas, kurang puas, puas, cukup puas, dan sangat puas. Berdasarkan hasil analisis data kuisioner yang diisi oleh 150 mahasiswa sebagai responden, didapatkan data tingkat kepuasan mahasiswa terhadap layanan bimbingan akademik yang ditunjukan dalam gambar 2 .

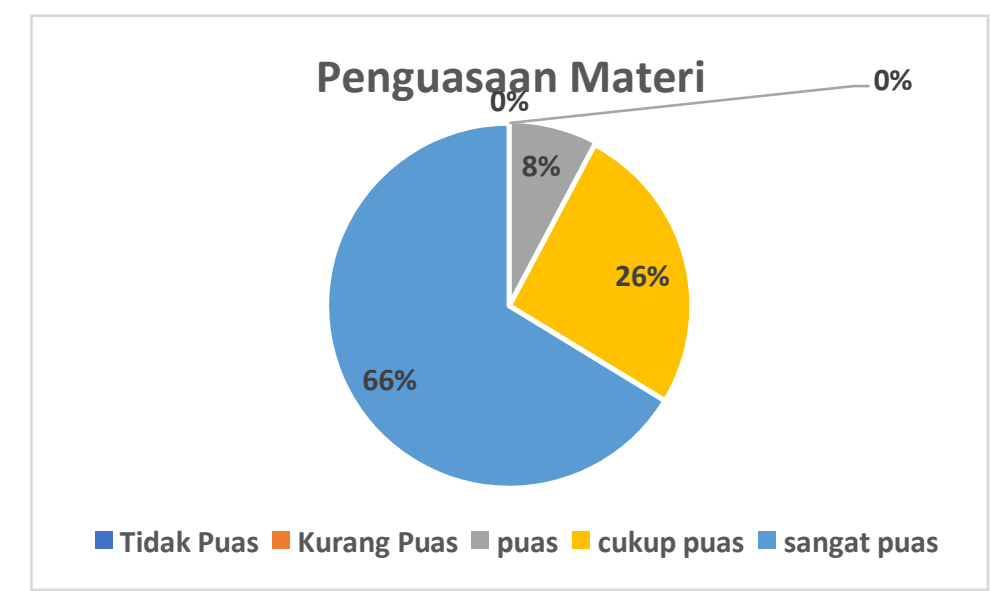

Gambar 2. Diagram tingkat kepuasan mahasiswa terhadap layanan bimbingan tugas akhir aspek penguasaan materi 
Vol 1 No 22020 Desember 2020

Jurnal AlphaEuclidEdu

Received: 25/11/2020; Revised: 30/11/2020; Accepted: 08/12/2020

Berdasarkan diagram di atas, dari 150 mahasiswa, sebanyak 0 mahasiswa merasa tidak puas, 0 mahasiswa merasa kurang puas, 12 mahasiswa merasa puas, 39 mahasiswa merasa cukup puas, dan 99 mahasiswa merasa sangat puas dengan layanan bimbingan tugas akhir aspek penguasan materi yang diberikan oleh para dosen yang bertupoksi sebagai dosen pembimbing skripsi di Program Studi Pendidikan Matematika Fakultas Keguruan dan Ilmu Pendidikan Universitas Tanjungpura

\section{Aspek Proses bimbingan}

Kepuasan mahasiswa terhadap layanan bimbingan tugas akhir pada aspek proses bimbingan diukur dengan 10 pernyataan dengan 5 tingkat kepuasan. 5 tingkat kepuasan yang digunakan adalah tidak puas, kurang puas, puas, cukup puas, dan sangat puas. Berdasarkan hasil analisis data kuisioner yang diisi oleh 150 mahasiswa sebagai responden, didapatkan data tingkat kepuasan mahasiswa terhadap layanan bimbingan akademik yang ditunjukan dalam gambar 3 .

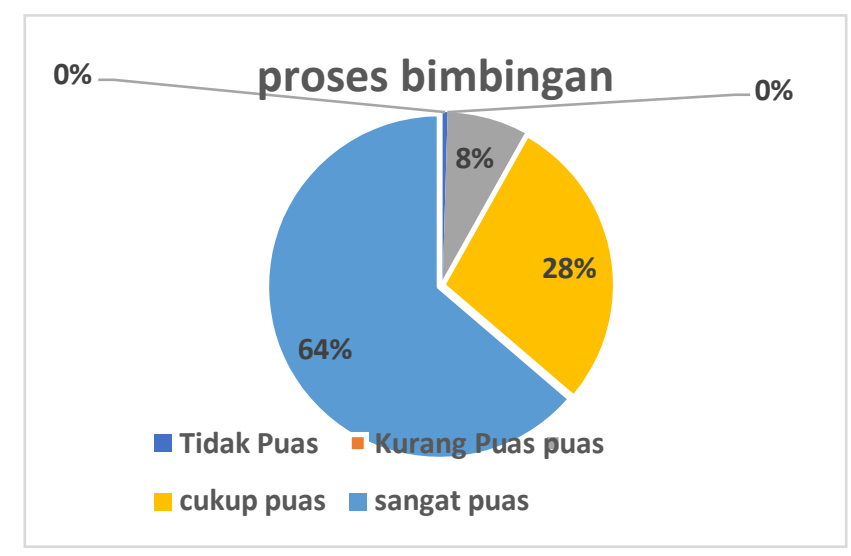

Gambar 3. Diagram tingkat kepuasan mahasiswa terhadap layanan bimbingan tugas akhir aspek proses bimbingan

Berdasarkan diagram di atas, dari 150 mahasiswa, sebanyak 0 mahasiswa merasa tidak puas, 0 mahasiswa merasa kurang puas, 12 mahasiswa merasa puas, 42 mahasiswa merasa cukup puas, dan 96 mahasiswa merasa sangat puas dengan layanan bimbingan tugas akhir aspek proses bimbingan yang diberikan oleh para dosen yang bertupoksi sebagai dosen pembimbing skripsi di Program Studi Pendidikan Matematika Fakultas Keguruan dan Ilmu Pendidikan Universitas Tanjungpura

\section{Aspek Proses Penyelesaian}

Kepuasan mahasiswa terhadap layanan bimbingan tugas akhir pada aspek proses bimbingan diukur dengan 10 pernyataan dengan 5 tingkat kepuasan. 5 tingkat kepuasan yang digunakan adalah tidak puas, kurang puas, puas, cukup puas, dan sangat puas. Berdasarkan hasil analisis data kuisioner yang diisi oleh 150 mahasiswa sebagai responden, didapatkan data tingkat kepuasan mahasiswa terhadap layanan bimbingan akademik yang ditunjukan dalam gambar 4 . 
Vol 1 No 22020 Desember 2020

Jurnal AlphaEuclidEdu

Received: 25/11/2020; Revised: 30/11/2020; Accepted: 08/12/2020

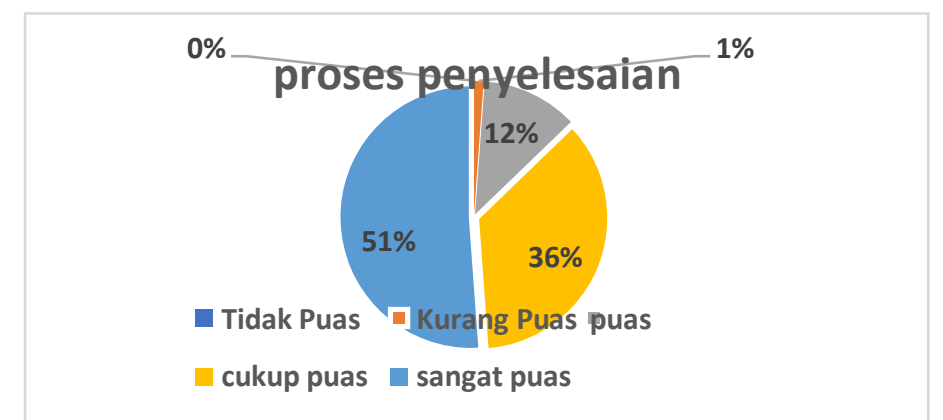

Gambar 4. Diagram tingkat kepuasan mahasiswa terhadap layanan bimbingan tugas akhir aspek proses penyelesaian

Berdasarkan diagram di atas, dari 150 mahasiswa, sebanyak 0 mahasiswa merasa tidak puas, 2 mahasiswa merasa kurang puas, 18 mahasiswa merasa puas, 53 mahasiswa merasa cukup puas, dan 77 mahasiswa merasa sangat puas dengan layanan bimbingan tugas akhir aspek proses penyelesaian yang diberikan oleh para dosen yang bertupoksi sebagai dosen pembimbing skripsi di Program Studi Pendidikan Matematika Fakultas Keguruan dan Ilmu Pendidikan Universitas Tanjungpura.

\section{Aspek Feedback dan Komentar}

Kepuasan mahasiswa terhadap layanan bimbingan tugas akhir pada aspek proses bimbingan diukur dengan 2 pernyataan dengan 5 tingkat kepuasan. 5 tingkat kepuasan yang digunakan adalah tidak puas, kurang puas, puas, cukup puas, dan sangat puas. Berdasarkan hasil analisis data kuisioner yang diisi oleh 150 mahasiswa sebagai responden, didapatkan data tingkat kepuasan mahasiswa terhadap layanan bimbingan akademik yang ditunjukan dalam gambar 5 .

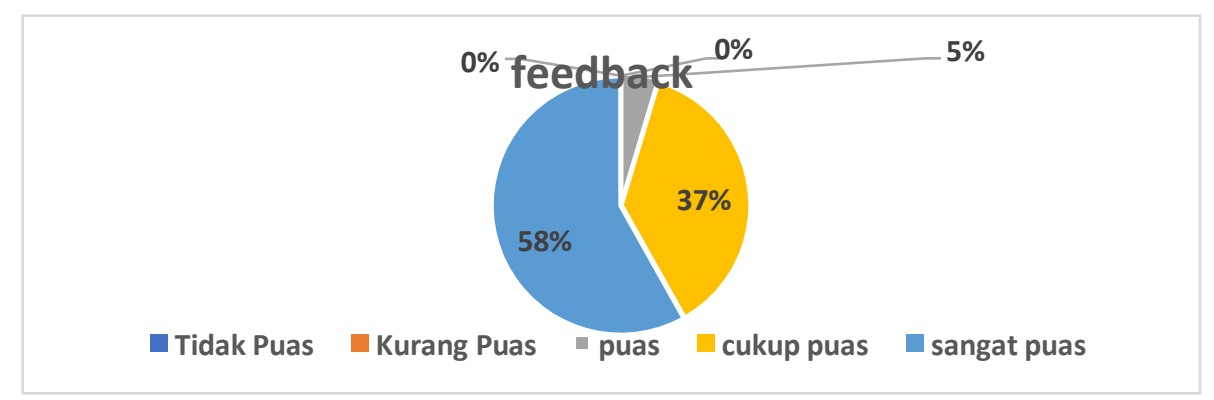

Gambar 5. Diagram tingkat kepuasan mahasiswa terhadap layanan bimbingan tugas akhir aspek feedback

Berdasarkan diagram di atas, dari 150 mahasiswa, sebanyak 0 mahasiswa merasa tidak puas, 0 mahasiswa merasa kurang puas, 8 mahasiswa merasa puas, 56 mahasiswa merasa cukup puas, dan 86 mahasiswa merasa sangat puas dengan layanan bimbingan tugas akhir aspek proses penyelesaian yang diberikan oleh para dosen yang bertupoksi sebagai dosen pembimbing skripsi di Program Studi Pendidikan Matematika Fakultas Keguruan dan Ilmu Pendidikan Universitas Tanjungpura 
Vol 1 No 22020 Desember 2020

Jurnal AlphaEuclidEdu

Received: 25/11/2020; Revised: 30/11/2020; Accepted: 08/12/2020

Kepuasan Mahasiswa Pada Layanan Bimbingan Tugas Akhir ( Data seluruh aspek)

Kepuasan mahasiswa terhadap layanan bimbingan tugas akhir diukur dengan seluruh pertanyaan kuisioner dengan 5 tingkat kepuasan. 5 tingkat kepuasan yang digunakan adalah tidak puas, kurang puas, puas, cukup puas, dan sangat puas. Berdasarkan hasil analisis data kuisioner yang diisi oleh 150 mahasiswa sebagai responden, didapatkan data tingkat kepuasan mahasiswa terhadap layanan bimbingan akademik yang ditunjukan dalam gambar 6 .

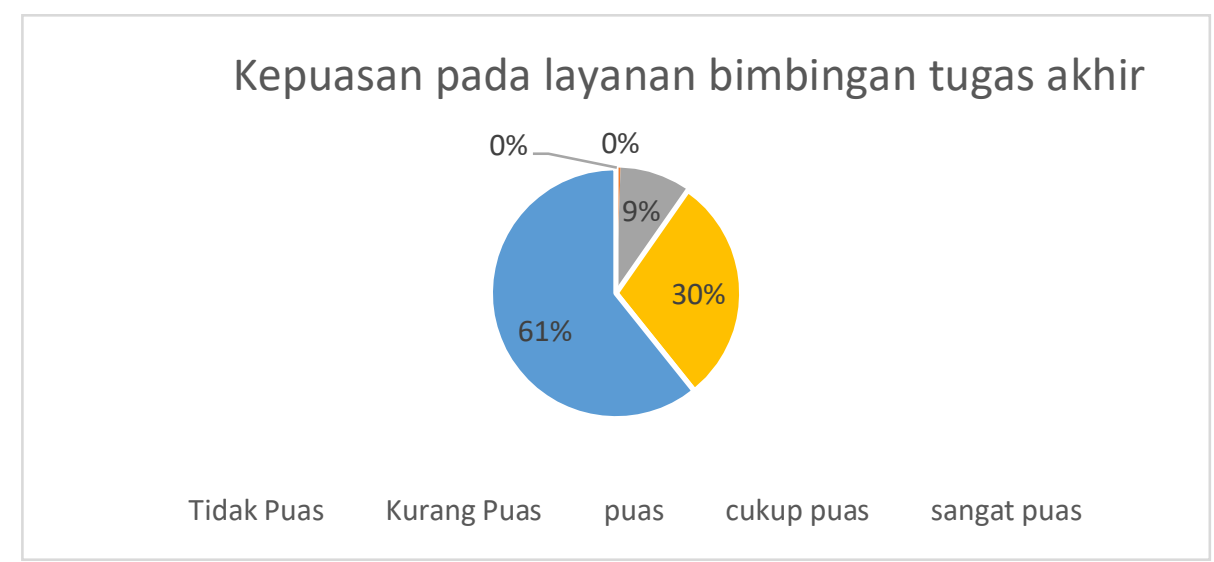

Gambar 6. Diagram tingkat kepuasan mahasiswa terhadap layanan bimbingan tugas akhir (data seluruh aspek)

Berdasarkan diagram di atas, dari 150 mahasiswa, sebanyak 0 mahasiswa merasa tidak puas, 0 mahasiswa merasa kurang puas, 14 mahasiswa merasa puas, 45 mahasiswa merasa cukup puas, dan 51 mahasiswa merasa sangat puas dengan layanan bimbingan tugas akhir yang diberikan oleh para dosen yang bertupoksi sebagai dosen pembimbing skripsi di Program Studi Pendidikan Matematika Fakultas Keguruan dan Ilmu Pendidikan Universitas Tanjungpura

\section{Pembahasan}

Berdasarkan analisis data kuisioner yang dilakukan dengan menghitung sebaran skor di setiap distribusi frekuensi kemudian diinterpretasikan dengan kriteria persentase, Pada aspek availabilitas dari 150 mahasiswa, tidak ada mahasiswa yang merasa tidak puas, $2 \%$ mahasiswa merasa kurang puas, $16 \%$ mahasiswa merasa puas, $31 \%$ mahasiswa merasa cukup puas, dan 51\% mahasiswa merasa sangat puas. Kemudian pada aspek penguasaan materi, dari 150 mahasiswa, tidak ada mahasiswa yang merasa tidak puas dan kurang puas, $8 \%$ mahasiswa merasa puas, 26\% mahasiswa merasa cukup puas, dan $66 \%$ mahasiswa merasa sangat puas. Pada aspek proses bimbingan, dari 150 mahasiswa, tidak ada mahasiswa yang merasa tidak puas dan kurang puas, $8 \%$ mahasiswa merasa puas, $28 \%$ mahasiswa merasa cukup puas, dan $64 \%$ mahasiswa merasa sangat puas. Lalu pada aspek proses penyelesaian, dari 150 mahasiswa, tidak ada mahasiswa yang merasa tidak puas, $1 \%$ mahasiswa merasa kurang puas, $12 \%$ mahasiswa merasa puas, $36 \%$ mahasiswa merasa cukup puas, dan 
Vol 1 No 22020 Desember 2020

Jurnal AlphaEuclidEdu

Received: 25/11/2020; Revised: 30/11/2020; Accepted: 08/12/2020

51\% mahasiswa merasa sangat puas. Pada aspek feedback, dari 150 mahasiswa, tidak ada mahasiswa yang merasa tidak puas dan kurang puas, $5 \%$ mahasiswa merasa puas, $37 \%$ mahasiswa merasa cukup puas, dan $58 \%$ mahasiswa merasa sangat puas.

Dari data 5 aspek tersebut di dapatkan data yang menunjukan tingkat kepuasan mahasiswa terhadap layanan bimbingan tugas akhir yang diberikan oleh para dosen yang bertupoksi sebagai dosen pembimbing skripsi di Program Studi Pendidikan Matematika Fakultas Keguruan dan Ilmu Pendidikan UniversitasTanjungpura, dari 150 mahasiswa, tidak ada mahasiswa yang merasa tidak puas dan kurang puas, 9\% mahasiswa merasa puas, $30 \%$ mahasiswa merasa cukup puas, dan $61 \%$ mahasiswa merasa sangat puas.

Secara umum, indikator kepuasan layanan bimbingan tugas akhir dinilai sudah memuaskan dengan hasil kepuasan 100\% ( Puas hingga sangat puas). Artinya pelayanan bimbingan akademik yang diberikan oleh para dosen yang bertupoksi sebagai dosen pembimbing skripsi mahasiswa Program Studi Pendidikan Matematika Fakultas Keguruan dan Ilmu Pendidikan Universitas Tanjungpura sudah optimal. Namun apabila dilihat dari masing - masing aspek yang diukur, masih ada beberapa persen mahasiswa merasa kurang puas dengan layanan yang telah diberikan para dosen yang bertupoksi sebagai dosen pembimbing skripsi mahasiswa Program Studi Pendidikan Matematika Fakultas Keguruan dan Ilmu Pendidikan Universitas Tanjungpura. yaitu pada aspek availabilitas dan aspek proses penyelesiaan. Hal ini dapat terjadi karena beberapa factor seperti kegiatan dosen pembimbing skripsi yang dimungkinkan sedang padat, dan juga dimungkinkan hilangnya motivasi dari mahasiswa tingkat akhir untuk menyelesaikan naskahnya,

Untuk meminimalisir hal tersebut bisa diberlakukan perjanjian atau kontrak bimbingan antara dosen pembimbing skripsi dengan mahasiswa bimbinganya agar terjadwal untuk bertemu dan berkonsultasi, hal ini juga dapat meminimalisir hilangnya motivasi mahasiswa tuk menyelesaikan tulisannya karena proses bimbingannya berjalan secara rutin.

\section{Kesimpulan dan Saran Kesimpulan}

Tingkat kepuasan mahasiswa terhadap layanan bimbingan tugas akhir adalah $0 \%$ mahasiswa merasa tidak puas, $0 \%$ mahasiswa merasa kurang puas, 9\% mahasiswa merasa puas, $30 \%$ mahasiswa merasa cukup puas, dan $61 \%$ mahasiswa merasa sangat puas. Dapat disimpulkan bahwa mahasiswa tingkat akhir Program Studi Pendidikan Matematika Fakultas Keguruan dan Ilmu Pendidikan Universitas Tanjungpura puas atas layanan yang telah diberikan oleh dosen pembimbing.

Hal- hal yang harus diperbaiki untuk meningkatkan kepuasan mahasiswa terhadap layanan bimbingan tugas akhir adalah diberlakukan perjanjian atau kontrak bimbingan antara dosen pembimbing skripsi dengan mahasiswa bimbinganya agar 
Vol 1 No 22020 Desember 2020

Jurnal AlphaEuclidEdu

Received: 25/11/2020; Revised: 30/11/2020; Accepted: 08/12/2020

terjadwal untuk bertemu dan berkonsultasi, hal ini juga dapat meminimalisir hilangnya motivasi mahasiswa tuk menyelesaikan tulisannya karena proses bimbingannya berjalan secara rutin.

\section{Saran}

Perlu dilakukan tindak lanjut dari hasil penelitian ini sehingga dapat meningkatkan mutu layanan dan mutu sumber daya manusa di Program Studi Pendidikan Matematika Fakultas Keguruan dan Ilmu Pendidikan Universitas Tanjungpura.

\section{Referensi}

Buchari Alma. 2009. Pemasaran Jasa Pendidikan yang Fokus Pada Mutu, dalam Buchari Alma dan Ratih Hurriyati (ed.), ManajemenCorporate \& Strategi Pemasaran Jasa Pendidikan. Bandung: Alfabeta.

Elliot, K..; Shin, D. 1999. Assessing student satisfaction: an approach to help in the development of marketing strategy for a university. Marketing Management Association.

Jurkowitsch, Silke, et.al. 2006, A Student Satisfaction Model For Austrian Higher Education Providers Considering Aspects Of Marketing Communications, Special Edition On Consumer Satisfaction - Global Perspective, pp. 9-23.

Kotler, Philip. 1997. Manajemen Pemasaran, Analisis, Perencanaan, Implementasi dan Control Jilid I. Edisi-9. Jakarta: PT Prenhallindo

Mahmud, Marzuki. 2012. Manajemen Mutu Perguruan Tinggi. Jakarta: Rajawali Press.

Supranto, J.2006. Pengukuran Tingkat Kepuasan Pelanggan. Jakarta: Rieneka Cipta Tampubolon.

Daulat P. 2001. Perguruan Tinggi Bermutu. Jakarta: PT. Gramedia Pustaka Utama Tjiptono, Fandy. 1997. Strategi Pemasaran. Yogyakarta: Andi Offset.

Yamif, Zuliam. 2001. Manajemen Kualitas Produk. Yogyakarta: Ekonisia.

Zeithaml, V.A. dan Bitner, M.J. 2000. Services Marketing: Integrating Customer Focus Across the Firm. (United States of America: Irwin McGraw-Hill. 

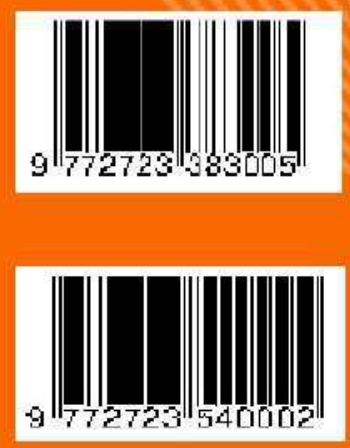